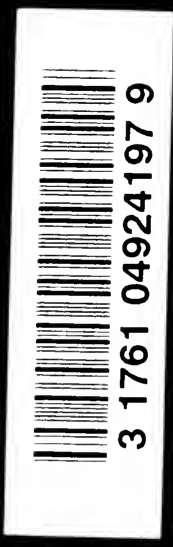




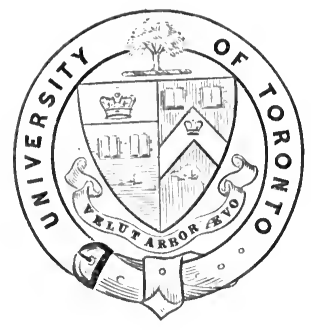

The 3. C. Faul Collection of Fineteentb Centure Engligh $\mathfrak{L}$ iterature

Ifurcbased in part through a contribution to the Library ffunds made by the Departiment of Englisb in Unipersity College. 




\title{
$\stackrel{\subseteq}{\subseteq}$ THE POETS
}

\section{GEOFFREY CHAUCER}

\author{
To \\ ALFRED TENNYSON
}

1340-1892

\section{IMPRESSIONS}

BY

\section{WILLIAM S'IEBBING}

HON. FELLOW OF WORCESTER COLLEGE, OXFORD AUTHOR OF 'SIR WALTER RALEGH : A BIOGRAPHY

\author{
VOL.' II
}

WORDSWOR'TH-TENNYSON

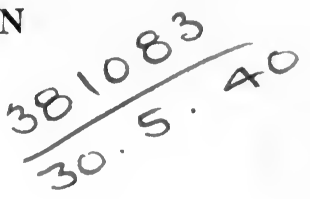

HENRY FROWDE

OXFORD UNIVERSITY PRESS

LONDON, NEW YORK AND TORONTO

1907 
OXFORD: HORACE HART

PRINTER TO THE UNIVERSITY 
Many exquisite lines quoted in the following pages are from poems comparatively recent; and I have pleasure in expressing my sense of the courtesy of the copyright-owners which has enabled me to include them. I am thus indebted to Messrs. Longmans, Green \& Co., in respect of verses by Cardinal Newman; to Messrs. Macmillan, for Lord Tennyson, Edward FitzGerald, Arthur Hugh Clough, and Matthew Arnold; to Messrs. Smith, Elder \& Co., for Robert Browning; to Messrs. Ellis, for Dante Gabriel Rossetti; to Mr. Aldis Wright, FitzGerald's executor, and to Mr. William Morris's and Mr. Robert Lou's Stevenson's trustees; to Mrs. Coventry Patmore, for The Unknown Eros, and to Messrs. George Bell \& Sons, its publishers; and to Messrs. Houghton, Mifflin \& Co., for James Russell Lowell.

With relation to the work in general of Lowell, as of Emerson, Poe, and Longfellow, Bryant, and Whittier, I must ask pardon of our American kinsmen, with whom we share the heritage of verse, for having yielded to the temptation of numbering all writers of inspired English poetry as members of one brotherhood. To British readers I need, I am sure, make no excuse. 
。 


\section{VOL. II \\ TABLE OF CONTENTS}

WILLIAM WORDSWORTH . . . . . . 1-16

Samuel Taylor Coleridge. . . . ' . 17-34

ROBERT SOUTHEY . . . . . . . . 35-44

WALTER SCOTT . . . . . . . . 45-55

JAMES HOGG . . . . . . . . . 56-64

Walter Savage Landor . . . . . • 65-74

Thomas Moore . . . . . . . . 75-81

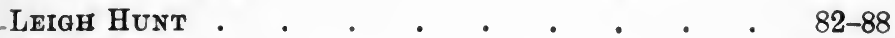

LORD BYRON . . . . . . . . 89-102

Percy Bysshe Shelley . . . . . . 103-116

JoHN KEATS • • • • • . . • . 117-129

Charles Wolfe . . . . . . . 130-135

Henty Hart Milman . . . . . . . 136-143

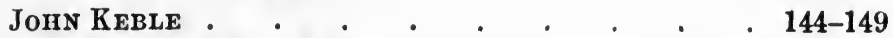

JOHN HENRY NEWMAN . . . . . . . 150-158

THOMAS HOOD . . . . . . . 159-167

Elizabeth Barrett Browning . . . . . 168-176

Charles Kingsley . . . . . . . 177-187

Ralph Waldo EMERSON . . . . . . 188-197

Edgar Allax Poe . • . . . . . . 198-206

HeNRY Wadsworth LoNgFellow . . . . 207-218

JAMES RUSSELl Lowell . . . . . . 219-228

Edward FitzGerald . . . . . . 229-239 
PAGES

Coventry Patmore . . . . . . . . 240-250

Dante Gabriel Rossetti . . . . . . 251-264

WILliam Morris . . . . . . . . 265-276

Arthur Hugh Clougir . . . . . . 277-285

MATthew ARNold . . . . . . . 286-298

ROBERT BROWNING . . . . . . . . 299-315

Alfred TenNyson . . . . . . . . . 316-333

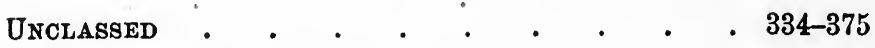

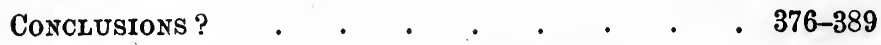

Births and Deaths . . . . . . . 391-393

INDEX OF FIRST Words . . . . . . 394-410 


\section{THE POETS}

\section{WILLIAM WORDSWOR'TH}

\section{$1770-1850$}

AN Evangelist among the heathen for thirty years. Supreme Pontiff for twenty. What is he now?

No student of literature can doubt what he was. In the history of learning Crusades are no novelties. The eighteenth century has a monopoly of crusading in poetry. Goethe and Schiller in Germany, de Musset, Victor Hugo, with the Romancists, in France, Wordsworth, at the head of the Lake School, in England, sang and fought, sang to fight. Elizabethan poets waged no wars; they were discoverers without being in the realm of fancy buccaneers, as some of them were on the Spanish Main. These others were invaders of established kingdoms, as were the Israelites of Canaan. Of all the combatant poets Wordsworth had set himself the hardest task, and won the most signal victory. His hand was against every man. He did not shun to wound a natural ally, a forerunner, like Cowper, an observer of rural life, like Thomson, in the blind battle! A fanatic doubtless, at once of wide views, and narrow ; but it was he who, though in the panoply of a Captain, fighting for the most part alone, taught how to replace poetic diction and epigrams by poetic ideas clothed in plain, pure English, with rhythm to match. Above all, it is to him mainly that literature owes the solemn inauguration of the worship of Nature. 
He threw down, and he built up. Though undoubtedly heralded by Cowper he substantially opened the new age of English verse, which closes for us with Tennyson. His famous brethren in song, more or less unconsciously, even mocking Byron, underwent his influence, while apparently they kept their independence. The later poetry of the nineteenth century has been, as a whole, though with some addition of melody, of his house and lineage. He accomplished a grand work in virtue of splendid poetic gifts, extraordinary philosophic insight, and obstinate, indomitable courage. As necessary a property for him, I fear, was, as for all great poets, Shakespeare, and perhaps Scott excepted, an absolute, and, in his case, innocent, incapacity for recognizing the existence of singers besides himself. Is it an intelligible contradiction in terms to say that, while he was addicted to warm moral indignation, and admiration, he had a cold heart ? An absence of the sense of humour was a part of his equipment which was, perhaps, essential. If it blinded him to absurdities in the exaggeration of his critical principles, it also steeled him against ignorant ridicule. Gallantly he flung down before adversaries, whom his inspiration bewildered and'enraged no less than his eccentricities, the gauntlet of his Peter Bell, weathercockless Kilve, Childless Timothy, Expostulation and Reply, with divers more as strange! Then, when the poet ceased to sing unless to an inner circle, what wisdom still, what understanding of the soul of things! The priest remained, with the inherent sanctity which had justified his original investiture with the poet's mantle. We feel him ready to go on prophesying should the commission be renewed; blissfully unconscious of the probable Never. Literary history shows few more pathetic figures than the old man, when visible within the diminished circle of his disciples ; 
a righteous witness and zealot, eager to defend the cause of poetical truth as in youth; with no foes to mock and persecute him; none for him to ban and burn: clad in sacerdotal robes above his armour; seeming to a careless, ungrateful world to be sacrificing cold-dead victims on a cold-dead altar.

I cannot but recognize that the mass of his verse has ceased to please. That is the common fate of poetry in masses. It must be conceded that the rule applies especially here. Ordinary readers even with a taste for poetry are satisfied with a fraction of his. As it happens, the few favourites are generally the fruit of earlier years. But comparisons of age may well be of interest for students of literature; they do not affect the question of absolute merit. When I am choosing pieces to make my own, and love, I do not consider dates. Similarly I do not concern myself with Wordsworth's philosophy, unless so far as it was the motive for a poem, and colours it. As it happened, the philosophy was of a kind to bear a very intimate relation to the poetry. The scheme of it was the pre-existence of spirit in an angelic state, and its now birth into a new order of Nature prepared for it by the Divine Arohitect. The fabric, with its appointed lord, was designed to be admirably fair and happy. In all its constituents, from man to beast, to the flowers of the field, mountain and valley, winds and waters, it was meant to develop by the law of its being into beauty, mutually grateful loving kindness, sympathy, symmetry, and harmony.

As a thinker he seems to have fashioned for himself some such system as this for our globe. Being a poet born he was in the habit of summoning inspiration to minister to the idea. I can understand the fascination to his elect disciples of watching the relation in his verse of 
the two powers, the two characters. A distinct chapter in psychology might be devoted to the manner in which the theory now and again subdues imagination to its service; now and again, though more in youth than age, while answering the summons, snatches up the Philosopher, and carries him, not where he, but where the Poet, would. It is not our province here to inquire whether he were primarily Poet because Philosopher, or Philosopher because Poet. For our purpose it is enough to appreciate his doctrine that Nature loves to clothe all her works with beauty; that she wishes her principal creature, man, to see it, enjoy it, imitate her in love and goodness to all ; that he ought to learn from the excellence, of Divine origin, in her and hers, how closely he is linked to Heaven. We need not, to discover the Poet in him, endeavour to piece together a complete system out of his verse. Let us delight ourselves with its charm, wherever we find itnot quarrelling with the sweetness, because the honeycomb may be hidden among the bones of a dead lion of thought.

To take offence at Wordsworth because the philosopher in him is, it must be acknowledged, never very far off, would be to banish ourselves from his kingdom of poetry altogether. Ideas, vast and lofty, are constantly discernible, willing to hold aloof or approach, as the reader will. Where any of therr insist upon associating themselves with the melody, welcome them; for the claim proves them and the inspiration to be one. Throughout ample spaces of garden-land where he reigns, thought, even for those who do not delve and mine in it, adds atmosphere and a sense of mystery. Who can account it ill in a poet that to his eyes Nature is always longing to demonstrate herself to be both delightful and beneficent! In a legion of 
instances he could not have done better poetically had he been searching for beauty with as little heed to a lesson from it as an Elizabethan minstrel of love. He could have produced no more spontaneous apparitions of metrical sweetness !

Lucy is not the less lyrically lovely that she impersonates Nature's ideal workmanship :

The floating elouds their state shall lend

To her ; for her the willow bend ;

Nor shall she fail to see

Even in the motions of the Storm

Grace that shall mould the Maiden's form

By silent sympathy.

The stars of midnight shall be dear

To her ; and she shall lean her ear

In many a secret place

Where rivulets dance their wayward round,

And beauty born of murmuring sound

Shall pass into her face. ${ }^{1}$

Her doom to an early death has not the less pathos in it that it may exemplify Nature's serene composure in bringing forth exquisite flowers only to fade :

She dwelt among the untrodden ways

Beside the springs of Dove,

A maid whom there were none to praise And very few to love ;

A violet by a mossy stone Half hidden from the eye ;-

Fair as a star, when only one

Is shining in the sky.

She lived unknown, and few could know

When Lucy eeased to be ;

But she is in her grave, and, oh,

The difference to me ! ${ }^{2}$ 
Here is an analysis of perfect, happy womanhood:

She was a Phantom of delight

When first she gleamed upon my sight;

A lovely Apparition sent

To be a moment's ornament ;

Her eyes as stars of Twilight fair ;

Like Twilight's, too, her dusky hair ;

But all things else about her drawn

From May-time and the cheerful Dawn ;

A dancing Shape, an Image gay,

To haunt, to startle, and waylay.

And now I see with eye serene

The very pulse of the machine;

A Being breathing thoughtful breath,

A Traveller between life and death;

The reason firm, the temperate will,

Endurance, foresight, strength, and skill ;

A perfect Woman, nobly planned,

To warn, to comfort, and command ;

And yet a Spirit still, and bright

With something of angelic light. ${ }^{3}$

With its wealth of insight, it stands on a level, neither higher nor lower, in poetical enchantment-since both are in that supreme-with the vision of the unknown Highland Reaper :

Behold her, single in the field,

Yon solitary Highland lass !

Reaping and singing by herself ;

Stop here, or gently pass !

Alone she cuts and binds the grain,

And sings a melancholy strain;

$O$ listen! for the Vale profound

Is overflowing with the sound.

No Nightingale did ever chaunt

More welcome notes to weary bands

Of travellers in some shady haunt,

Among Arabian sands; 
A voice so thrilling ne'er was heard

In spring-time from the Cuckoo-bird,

Breaking the silence of the seas

Amongst the farthest Hebrides.

Will no one tell me what she sings ?

Perhaps the plaintive numbers fow

For old, unhappy, far-off things,

And battles long ago ;

Or is it some more humble lay,

Familiar matter of to-day?

Some natural sorrow, loss or pain,

That has been, or may be again ?

Whate'er the theme, the Maiden sang

As if her song could have no ending ;

I saw her singing at her work,

And o'er the sickle bending -

I listened, motionless and still ;

And, as I mounted up the hill,

The music in my heart I bore,

Long after it was heard no more. ${ }^{4}$

The full orchestra provided for the poet by his winged neighbours in his native dales has a world of various meaning for him. Yet how simply, and unscholastically, sweet, is each several carol! The Nightingale plays at stirring the restless blood, which the stock-dove would soothe:

O Nightingale! thou surely art

A creature of a fiery heart ;

These notes of thine-they pierce and pierce;

Tumultuous harmony and fierce !

Thou sing'st as if the God of wine

Had helped thee to a Valentine ;

A song in mockery and despite

Of shades, and dews, and silent night;

And steady bliss, and all the loves

Now sleeping in their peaceful groves. ${ }^{5}$ 
The Skylark teaches that love may both aspire and cherish :

Ethereal minstrel! pilgrim of the sky!

Dost thou despise the earth where cares abound !

Or, while the wings aspire, are heart and eye

Both with thy nest upon the dewy ground ?

Thy nest which thou canst drop into at will,

Those quivering wings composed, that music still !

Leave to the nightingale her shady wood;

A privacy of glorious light is thine ;

Whence thou dost pour upon the world a flood

Of harmony, with instinct more divine ;

Type of the wise who soar, but never roam;

True to the kindred points of Heaven and Home ${ }^{6}$

The Linnet seems to preach not at all, but has his lesson too-that Nature commands to be glad:

One have I marked, the happiest gucst

In all this covert of the blest;

Hail to thee, far above the rest

In joy of voice and pinion!

Thou, Linnet! in thy green array,

Presiding Spirit here to-day,

Dost lead the revels of the May;

And this is thy dominion.

While birds and butterflies, and flowers,

Make all one band of paramours,

Thou, ranging up and down the bowers,

Art sole in thy employment;

A Life, a Presence like the Air,

Scattering thy gladness without care,

Too blest with any one to pair ;

Thyself thy own enjoyment.?

Fit companion is he in his airy pulpit for the joyous wild flowers that the poet surprised, revelling too, one spring on the shores of Grasmere:

A host, of golden daffodils,

Beside the lake, beneath the trees,

Fluttering and dancing in the breeze. 
Continuous as the stars that shine, And twinkle on the milky way, They stretched in never-ending line Along the margin of a bay: Ten thousand saw $I$ at a glance, Tossing their heads in sprightly dance,

The waves beside them danced; but they Outdid the sparkling waves in glee ;

A poet could not but be gay, In such a jocund company. ${ }^{8}$

Universal nature, in his creed, was designed to rejoice, and insists on rejoicing; but no investiture with a prophet's mantle is required to qualify lovers of inspired verse to feel the magic, the exulting happiness, of the strains in which the Poet of Nature proclaims his faith and glory in her beauty and tenderness.

Commonly it is possible to be thus sensible of the simple singer, apart from the seer, in Wordsworth-not always. I cannot pretend to press an indiscriminate resort to him for the amusement of an idle hour. He has strains of a grandeur, a beauty of sublimity, which it seems profane to rehearse unless as anthems chanted by worshippers with bare feet before an altar. From how far away seems to echo the soliloquy:

Earth has not anything to show more fair ;

Dull would he be of soul who could pass by

A sight so touching in its majesty;

This City now doth, like a garment, wear The beauty of the morning; silent, bare, Ships, towers, domes, theatres, and temples lie

Open unto the fields, and to the sky ;

All bright and glittering in the smokeless air.

Never did sun more beautifully steep

In his first splendour, valley, rock, or hill ; 
Ne'er saw I, never felt, a calm so deep ! The river glideth at his own sweet will; Dear God ! the very houses seem asleep ; And all that mighty heart is lying still !?

It is a Voice in the wilderness which, not affecting to be able to cure the disease, protests against personal contamination by the prevailing divorce of flesh from spirit, of Earth from Heaven:

The world is too much with us; late and soon,

Getting and spending, we lay waste our powers ;

Little we see in Nature that is ours;

We have given our hearts away, a sordid boon!

This Sea that bares her bosom to the moon;

The winds that will be howling at all hours,

And are up-gathered now like sleeping flowers;

For this, for everything, we are out of tune ;

It moves us not.-Great God! I'd rather be

A Pagan suckled in a creed outworn;

So might I, standing on this pleasant lea,

Have glimpses that would make me less forlorn;

Have sight of Proteus rising from the sea ;

Or hear old Triton blow his wreathèd horn ! ${ }^{10}$

Listen finally to the two emulous rivals for control of Wordsworth's soul-Thought the profoundest, Imagination at its loveliest-coalescing, as in the mighty Ode, into a long-resounding peal of music, realizing the Miltonic vision of Philosophy, celestially harmonious :

The Rainbow comes and goes,

And lovely is the Rose ;

The Moon doth with delight

Look round her when the heavens are bare;

Waters on a starry night

Are beautiful and fair;

The sunshine is a glorious birth;

But yet I know, where'er I go,

That there hath past away a glory from the earth. 
Our birth is but a sleep and a forgetting : The Soul that rises with us, our life's Star,

Hath had elsewhere its setting,

And cometh from afar ;

Not in entire forgetfulness,

And not in utter nakedness,

But trailing clouds of glory do we come

From God, who is our Home ;

Heaven lies about us in our infancy!

Shades of the prison-house begin to close

Upon the growing Boy,

But he beholds the light, and whence it flows,

He sees it in his joy ;

The Youth, who daily farther from the east

Must travel, still is Nature's Priest,

And by the vision splendid

Is on his way attended ;

At length the Man perceives it die away, And fade into the light of common day.

$O$ joy! that in our embers

Is something that doth live,

That nature yet remembers

What was so fugitive!

The thought of our past years in me doth breed

Perpetual benediction; not indeed

For that which is most worthy to be blest;

Delight and liberty, the simple creed

Of Childhood, whether busy or at rest ;

But for those first affections,

Those shadowy recollections,

Which, be they what they may,

Are yet the fountain light of all our day.

Are yet a master light of all our seeing !

Hence in a season of calm weather,

Though inland far we be,

Our Souls have sight of that immortal sea

Which brought us hither,

Can in a moment travel thither, 
And see the Children sport upon the shore, And hear the mighty waters rolling evermore.

And 0 , ye Fountains, Meadows, Hills, and Groves, Forebode not any severing of our loves !

Yet in my heart of hearts I feel your might ;

I only have relinquished one delight

To live beneath your more habitual sway.

Thanks to the human heart by which we live,

Thanks to its tenderness, its joys, its fears,

To me the meanest flower that blows can give

Thoughts that do often lie too deep for tears. ${ }^{11}$

A consecration of music, as in this marvel, to the evolution of abstract thought must in the nature of things be exceptional. Yet the pursuers after melody may find their reward in exploring even the cold, dry places in the Master's philosophy. Grace and fire frequently will reveal themselves in unexpected spots. A bold defiance of the intolerant literary canons of his youth, like Peter Bellthe butt of Byron-blossoms into some transcendent lines :

In vain, through every changeful year,

Did Nature lead him as before;

A primrose by a river's brim

A yellow primrose was to him,

And it was nothing more.

At noon, when by the forest's edge,

He lay beneath the branches high,

The soft blue sky did never melt

Into his heart; he never felt

The witchery of the soft blue sky ! ${ }^{12}$

An aspiring reflection will without warning break into gentle song :

The bees that soar for bloom,

High as the highest peak of Furness Fells,

Will murmur by the hour in foxglove bells. 
In a treatise, as Unbelievers might deem it, on Religious Faith, suddenly steps:

from the blazing chariot of the sun

A beardless Youth, who touched a golden lute, And filled the illumined groves with ravishment. The nightly hunter, lifting a bright eye Up towards the crescent moon, with grateful heart Called on the lovely wanderer who bestowed That timely light, to share his joyous sport; And hence, a beaming Goddess with her Nymphs, Across the lawn and through the darksome grove, Not unaccompanied with tuneful notes By echo multiplied from rock or cave, Swept in the storm of chase; as moon and stars Glance rapidly along the clouded heaven, When winds are blowing strong. ${ }^{13}$

From the dreary, flinty groundwork of poor Simon Lee's infirmities is struck out a swift, illuminating spark, as tears speak his astonished thankfulness for a petty kindness :

I've heard of hearts unkind, kind deeds

With coldness still returning;

Alas! the gratitude of men

Hath oftener left me mourning. ${ }^{14}$

Sirach, the Son of Consolation, might have learnt much from Margaret's complaint of the neighbourly attempts at comfort to her in her bereavement:

They pity me, and not my grief ! 15

They who neglect their Wordsworth do not know how much they lose in a multitude of ways. The least study will convince of the folly of the description of the philosophy itself as 'wordy, drowzy, frowzy'. It is, on the contrary, a body of thought elevating, comforting, and cheeringoften in a setting as artistically harmonious as it is touchingly natural. The poet had studied man; and while he sees cause to lament 


\section{THE POETS}

What man has made of man;

he recognizes with joy that, nevertheless,

We have all of us one human heart.

He is grateful to Nature, and to Nature's source, that, in improving earth's surface into infinite loveliness, they have not neglected the development of man also. There is many a one who,

doomed to go in company with Pain, And Fear, and Bloodshed, miserable train, Turns his necessity to glorious gain. ${ }^{16}$

He thanks Heaven for Milton, whose soul was like a star, and dwelt apart ; ${ }^{17}$

for Burns, who

showed my youth

How Verse may build a princely throne

On humble truth ${ }^{18}$

for the plough-boy's merry whoop; and for the stately Beggar-woman:

a creature

Beautiful to see-a weed of glorious feature! 19

for the proofs of humanity's ability to rise superior to fortune, afforded alike by the Royal Swede, and by the leech-gatherer, motionless as a cloud, on the lonely moor :

I could have laughed myself to scorn to find

In that decrepit man so firm a mind ; ${ }^{20}$

for Spring's bestowal of a train of flowers :

a mighty band,

Singing at my heart's command ;

for the spirit breathed for him in the woods, which made

the sounding cataract

Haunt him like a passion;

and had justified his prayer and hope, as he meditates gratefully on the choir of Poets: 
who on earth have made us heirs Of truth and pure delight by heavenly lays! Oh ! might my name be numbered among theirs, Then gladly would I end my mortal days. ${ }^{21}$

There are poets whose works are each a body of literature in itself ; and Wordsworth is of them. Though $I$ have dared to touch various keys in his mighty organ, I have refrained from a hundred more. With many a grieving look back, I have passed the Yarrows by, the vision of the Girl of Inversneyde, the Sonnet's sonnet, the overflowing music of Brougham Castle's welcome to its Shepherd Lord, the high-minded farewell to the "wondrous Potentate' of Eildon's triple height, the dramatic force and generous appeal of Hart-leap Well, the pathos of the improvised requiem on departed fellows in song, the grace and the passion of Laodamia, wild-flower Ruth, and the golden Duddon ehain, with numberless things of beauty and wisdom besides. Single pieces, like the great Ode, are matter for entire volumes. Together they reflect the whole poetry of life as lived, and as it ought to be lived. In that unison I find in effect an explanation of the common indifference to Wordsworth's later verse. He mixed so much of his self-communings, the conviction of his obligation to rebuke, reform, and teach, that the Poet often was lost to view in the Preacher. Is it too much to assume that to it also, to the absolute identity of the man and his inspiration, the indefinable magic of the earlier poetry must be traced! Nowhere in the English Helicon is it harder to track home the fascination, by so much as it is always harder to analyse an author than his book. When, however, it can be done, and is done, when, as in the morning of life, the poet poured his whole soul into his verse, when he followed after every aspiration with the ardour of a 
lover as well as the patience of a teacher, when he arrayed each in diction as lovely as it is simple, I do not wonder that the best of the nation's youth rallied to his bugle call. Even from the far distance, believe me, its echoes enchant. Let any submit themselves honestly to the spell, and they will understand.

The Poetical Works of William Wordsworth. Edward Moxon, 1847.

1 Three Years she Grew in Sun and Shower (Poems of the Imagination, $\mathrm{X})$, p. 144.

2 Lucy (Poems of the Affections, VIII), pp. 77-8.

${ }^{3}$ She was a Phantom of Delight (Poems of the Imagination, VIII), p. 143.

4 The Solitary Reaper (Memorials of a Tour in Scotland, IX), p. 223.

- To a Nightingale (Poems of the Imagination, IX), pp. 143-4.

- To a Skylark (ibid., XXX), p. 162.

7 The Green Linnet (Poems of the Fancy, IX), p. 118.

${ }^{8}$ Daffodils (Poems of the Imagination, XII), p. 144.

- Composed upon Westminster Bridge, Sept. 3, 1802 (Miscellaneous Sonnets, XXXVI), p. 209.

${ }^{10}$ Sonnet XXXIII (Miscellaneous Sonnets), p. 203.

11 Intimations of Immortality from Recollections of Early Childhood. Ode, stanzas 2, 5, 9, and 11, pp. 441-3.

12 Peter Bell, Part I, stanzas 12 and 15 (Poems of the Imagination), p. 187.

${ }^{13}$ The Excursion, Book IV, p. 483.

14 Simon Lee, the Old Huntsman, st. 12 (Poems of Sentiment and Reflection, VI), p. 364.

15 The Affliction of Margaret, st. 11 (Poems founded on the Affections, XXIV), p. 85.

18 Character of the Happy Warrior (Poems of Sentiment and Reflection, $\mathrm{XX)}$, p. 371.

${ }^{17}$ London, 1802 (Poems dedicated to National Independence, XIV), p. 238.

18 At the Grave of Burns, 1803, st. 6 (Memorials of a Tour in Scotland, II), p. 219.

19 Written in March, and Beggars (Poems of the Imagination, XVI and XVIII), pp. 146 and 147.

${ }^{20}$ Resolution and Independence, st. 20 (ibid., XXII), p. 153.

21 Personal Talk, XIII (Poems of Sentiment and Reflection, IV), p. 368. 


\section{SAMUEL TAYLOR COLERIDGE}

\section{$1772-1834$}

Wнат a poet but for the metaphysician!

A poet feels ; a metaphysician reasons. The one leaps; the other digs. Without imagination the one cannot breathe; and the other cannot guess at the lie of a lode. But for the poet, it is life ; for the metaphysician, a stimulant. In the same mind the two tendencies conflict, unless one consent to serve. To his friends and the Highgate circle Coleridge was the more signal marvel because he united both. For posterity he would have been a profounder philosopher had he been less of a poet. Had he concerned himself less with the solution of mental problems, he must have filled a wider, not a more exalted, space in the history of poetry.

His positive poetical career was brief. The quantity of his work in the period is moderate. Virtually the whole bears an unmistakable stamp of high intelligence and noble feeling. I read Religious Musings, and find grand images and mines of reflection; as, for instance, that in our Heavenly Father's vast human family

$$
\text { no Cain }
$$

Injures-uninjured-in her best aim'd blow Victorious murder a blind suicide ;

or the lines immediately preceding, which Lamb declared to be ' without a rival in the whole compass of my poetical reading' :

VOL. II 
There is one Mind, one omnipresent Mind, Omnific. His most holy name is Love. Truth of subliming import! with the which Who feeds and saturates his constant soul, He from his small particular orbit flies With blest outstarting ! From himself he flies, Stands in the sun, and with no partial gaze Views all creation; and he loves it all, And blesses it, and calls it very good !

This is indeed to dwell with the most High !

Cherubs and rapture-trembling Seraphim

Can press no nearer to the Almighty's Throne. ${ }^{1}$

I pass to The Eolian Harp, in its author's belief, 'the most perfect poem he ever wrote' - and am charmed, as

$$
\text { its strings }
$$

Boldlier swept, the long sequacious notes

Over delicious surges sink and rise, Such a soft floating witchery of sound

As twilight Elfins make, when they at eve

Voyage on gentle gales from Fairy-land !

$O$ the one life within us and abroad,

Which meets all motion and becomes its soul, A light in sound, a sound-like power in light, Rhythm in all thought, and joyance everywhere ! ${ }^{2}$

No subtlety, the most intricate, daunts his Muse, when the theme crosses her path; not even David Hartley's Aether, with its

fluids, impacts, essences,

Self-working tools, uncaused effects, and all

Those blind omniscients, those almighty slaves,

Untenanting creation of its God. ${ }^{3}$

I stand amazed at the more than equal courage of the Ne Plus Ultra:

Sole Positive of Night !

Antipathist of Light !

Fate's only essence! primal scorpion rod-

The one permitted opposite of God !- 
Condensed blackness and abysmal storm

Compacted to one seeptre Arms the Grasp enorm-

The Intercepter-

The Substance that still casts the shadow Death !-

The Dragon foul and fell-

The unrevealable,

And hidden one, whose breath

Gives wind and fuel to the fires of Hell !-

$\mathrm{Ah}$ ! sole despair

Of both th' eternities in Heaven !

Sole interdict of all-bedewing prayer,

The all-compassionate!

Save to the Lampads Seven

Reveal'd to none of all th' Angelic State,

Save to the Lampads Seven,

That wateh the throne of Heaven ! ${ }^{4}$

The brain reeling thence soothes itself, notwithstanding the encroaching waves even here of wrangling politics, in the Ode to the Departing Year, with its proud invocation :

O Albion ! O my mother Isle !

Thy valleys, fair as Eden's bowers,

Glitter green with sunny showers;

Thy grassy uplands' gentle swells

Echo to the bleat of flocks-

Those grassy hills, those glittering dells

Proudly ramparted with rocks-

And Ocean mid his uproar wild

Speaks safcty to his island-child.

Hence for many a fearless age

Has-social Quiet loved thy shore;

Nor ever proud invader's rage

Or sack'd thy towers, or stain'd thy fields with gore. ${ }^{5}$

Amidst the troubling Fears in Solitude it takes refuge in dreams of better worlds, and in the lowly charms of our own : 
The fruit-like perfume of the golden furze;

This burst of prospect, here the shadowy main,

Dim-tinted, there the mighty majesty

Of that huge amphitheatre of rich

And elmy fields ; 6

or in The Picture paints a delicious landscape, where

with dun-red bark

The fir-trees, and the unfrequent slender oak,

Forth from a tangle wild of bush and brake

Soar up, and form a melancholy vault

High o'er me, murmuring like a distant sea ;

and girdle a quiet woodland pool, with, uncertainly mirrored in it, 'her-divinest maid'-the genius of the whole-centre there of a phantom world of trees and flowers.?

Then, there are ideal vers de société, such as :

I ask'd my fair one happy day,

What I should call her in my lay;

By what sweet name from Rome or Greece ;

Lalage, Necra, Chloris,

Sappho, Lesbia, or Doris,

Arethusa, or Lucrece ;

'Ah !' replied my gentle fair,

'Beloved, what are names but air?

Choose thou whatever suits the line;

Call me Sappho, call me Chloris,

Call me Lalage or Doris,

Only, only call me thine.' ${ }^{8}$

Epigrams issued in swarms, political, social, merry, malicious sometimes, almost always brilliant. There is the terrible scream at Pitt in Fire, Famine, and Slaughter. ${ }^{9}$ There are sonorous sonnets, on Schiller's 10 Robbers, and on Kosciuszko : 
$O$ what a loud and fearful shriek was there, As though a thousand souls one death-groan pour'd!

Ah me! they saw beneath a hireling's sword

Their Koseiusko fall ! 11

Frost at midnight impresses with a quiet which may be felt :

'Tis ealm indeed! so calm, that it disturbs And vexes meditation with its strange And extreme silentness. Sea, hill, and wood, This populous village! sea, and hill, and wood, With all the numberless goings-on of life, Inaudible as dreams ! ${ }^{12}$

The Knight's Tomb, with the elegance of a Greek epigram, has the sighing sadness of a breeze among yellow autumn leaves:

Where is the grave of Sir Arthur O'Kellyn?

Where may the grave of that good man be ?

By the side of a spring, on the breast of Helvellyn,

Under the twigs of a young birch tree !

The oak that in summer was sweet to hear, And rustled its leaves in the fall of the year, And whistled and roar'd in the winter alone, Is gone-and the birch in its stead is grownThe Knight's bones are dust, and his good sword rust :

His soul is with the saints, I trust. ${ }^{13}$

The winning simplicity of A Christmas Carol clothes an idea not the less profoundly beautiful that the joy of the Virgin Mother at the Shepherds' message from the Angels was a protest against modern Europe's carnival of war :

She listen'd to the tale divine,

And eloser still the Babe she prest;

And while she cried, the Babe is mine !

The milk rush'd faster to her breast :

Joy rose within her, like a summer's morn ;

Peace, Peace on Earth! the Prince of Peace is born. ${ }^{14}$ 
An Epitaph on an Infant has neither special novelty nor depth; but what a tenderness !

Ere Sin could blight, or Sorrow fade,

Death came with friendly care ;

The opening bud to Heaven convey'd,

And bade it blossom there. ${ }^{15}$

And the same many-sided fancy, hearing of the birth of a son, wavers between welcome to his life and to his death:

$\mathrm{O}$ my sweet baby ! when I reach my door, If heavy looks should tell me thou art dead, I think that I should struggle to believe

Thou wert a spirit. ${ }^{16}$

In the Three Graves it produces a sketch, which even it had not the heart to finish. The Thing is shudderingly bare, like a corpse in the Morgue ; shorn of all comeliness ; squalidly tragic and cruel. Yet the harsh force of it !

' $O$ God, forgive me,' he exclaim'd ;

I have torn out her heart! 17

Happily, we have not to wait long before we may forget the nightmare in the sunshine of

An Idyll with Boccaccio's spirit warm,

Framed in the silent poesy of form..$^{18}$

Imagination has transported the Georgian poet four long centuries back to that fate-defying ' Garden and its faery'; to

The brightness of the world, $\mathrm{O}$ thou once free, And always fair, rare land of courtesy !

O Florence! with the Tuscan fields and hills, And famous Arno, fed with all their rills ; Thou brightest star of star-bright Italy !

Rich, ornate, populous, all treasures thine, The golden corn, the olive, and the vine. Fair cities, gallant mansions, castles old, And forests, where beside his leafy hold 
The sullen boar hath heard the distant horn, And whets his tusks against the gnarled thorn ; Palladian palace with its storied halls;

Fountains, where Love lies listening to their falls;

Gardens, where flings the bridge its airy span, And Nature makes her happy home with man; Where many a gorgeous flower is duly fed With its own rill, on its own spangled bed.Thine all delights, and every muse is thine ; And, more than all, the embrace and intertwine Of all with all in gay and twinkling dance ! Mid gods of Greece and warriors of romance, See ! Boccace sits, unfolding on his knees The new-found roll of old Maeonides;

But from his mantle's fold, and near the heart, Peers Ovid's holy book of Love's sweet smart. ${ }^{19}$

The tale of Coleridge's achievements in verse is far from told yet. He could do anything with verse. If he did not compose an epic, we may be sure it was not because he could not. If his few songs are not perfect music, it is that he could not sing without thinking. He produced plays, which are poems also ; ideal translations, the Piccolomini and the Death of Wallenstein ; and-besides prodigies which I am holding over in reserve-three great Odes.

That to France,

a solemn music of the wind,

is a grand declaration of the superiority of his loyal faith in Freedom to disenchantment by the greediness of renegades seduced, as had been Frenchmen,

To mix with Kings in the low lust of sway,

Yell in the hunt, and share the murderous prey. ${ }^{20}$

No dithyramb on the overwhelming glory of Alpine peaks has ever surpassed in splendour of diction his Hymn to Mont Blanc. It is immaterial that he was indebted for an outline of the poem to an obscure German poetess. 
That he had never seen the mountain or valley gave additional freedom to his enthusiasm. As it is, the conception moves apart on a high level from which it never descends :

Sole sovran of the Vale!

$O$ struggling with the darkness all the night, And visited all night by troops of stars,

Or when they climb the sky or when they sink :

Companion of the morning-star at dawn, Thyself Earth's rosy star, and of the dawn Co-herald; wake, $\mathrm{O}$ wake, and utter praise ! Who sank thy sunless pillars deep in Earth ? Who fill'd thy countenance with rosy light ? Who made thee parent of perpetual streams? And you, ye five wild torrents fiercely glad! Who call'd you forth from night and utter death, From dark and icy caverns call'd you forth, Down those precipitous, black, jagged Rocks, For ever shatter'd and the same for ever ?

Ye ice-falls! Ye that from the mountain's brow Adown enormous ravines slope amainTorrents, methinks, that heard a mighty voice, And stopp'd at once amid their maddest plunge! Motionless torrents! silent cataracts !

Who made you glorious as the gates of Heaven Beneath the keen full moon? Who bade the sun Clothe you with rainbows? Who, with living flowers Of loveliest blue, spread garlands at your feet ?God! let the torrents, like a shout of nations, Answer! and let the ice-plains echo, God! 21

The perfection of stateliness, though pitched too entirely in one key! Yet not comparable, either for harmony or for thought, to the Ode to Dejection. Can that be given higher praise than that it is worthy to rank beside the Intimations of Immortality in the forefront of philosophical verse! If the scope is necessarily far less large, and as necessarily the prospect is darker, the narrower plan is as 
exactly balanced; any propensity to rhetoric is as well restrained. The melody, of which alone I can in a fragment give an idea, is always admirable :

\section{What a scream}

Of agony by torture lengthen'd out

That lute sent forth! Thou Wind, that ravest without,

Bare crag, on mountain-tairn, or blasted tree,

Or pine grove whither woodman never clomb,

Or lonely house, long held the witches' home,

Methinks were fitter instruments for thee,

Mad Lutanist! who in this month of showers,

Of dark-brown gardens, and of peeping flowers,

Mak'st Devils' Yule, with worse than wintry song,

The blossoms, buds, and timorous leaves among.

Thou Actor, perfect in all tragic sounds !

Thou mighty Poet, e'en to frenzy bold !

What tell'st thou now about?

'Tis of the rushing of a host in rout,

With groans of trampled men, with smarting wounds-

At once they groan with pain, and shudder with the cold !

But hush there is a pause of deepest silence!

And all that noise, as of a rushing crowd

With groans and tremulous shudderings-all is over-

It tells another tale, with sounds less deep and loud !

A tale of less affright,

And temper'd with delight,

As Otway's self had framed the tender lay,

'Tis of a little child

Upon a lonesome wild,

Not far from home, but she hath lost her way;

And now moans low in bitter grief and fear,

And now screams loud, and hopes to make her mother hear. ${ }^{22}$

I recognize the touch of greatness everywhere: the abounding flood of majestic thought and imagery, which enraptured friends, and bewildered them no less than foes. It is possible to dissect piece after piece, and demonstrate the grandeur, the beauty. But the common reader of 
poetry who, like myself, reads poems to find out which of them he can love, is not drawn irresistibly back. These noble Odes, Hymns, Musings, Sonnets, even Epigrams, and jeux d'esprit are not in general of the poetry with which we care to live. And why?

Defects are visible on the surface of many. Often it is preaching instead of singing. Extraneous currents of thought are permitted to encroach. Indignation, in itself righteous, may be inopportune. It roars with a noisiness which fatigues. The fault is as in penmanship, when the upstroke and downstroke are equally dark. A suspicion is excited, as in the Chamouni Pindaric, that the eagle is flapping his wings to gain impetus for the flight heavenwards. Imagination itself effloresces into a confusing exuberance-fancy upon fancy-reflection upon reflection. The congeries is rather material for poetry than poetry itself. Poems by other writers have, it is true, maintained their place in popular estimation in the face of drawbacks as considerable. But in Coleridge I cannot but suppose that they grew out of an essential misconception by him of the rights of verse over the versifier. Poetry demands the choicest of a man's powers ; if great powers, the greatest, and all of them. He should have a will, and the will to mass the whole, and throw it into the lap of his theme. Coleridge had no sufficient sincerity in his vocation, no full conviction of the supreme obligations of the poet's mantle. Nature had bestowed the gift of verse upon him as his proper mode of expression ; and he used it as lightly as he came by it. Apparently he was not conscious that there is agony as well as rapture in the due utterance of such a voice. A reader like myself is liable to the distasteful feeling that he has had offered to him a series of exercises instead of inspired messages ; that they represent 
the obedience of a marvellous assemblage of human energies to their lord and master, and not the empire of his poetic spirit over himself

The surprise is to turn a page, and be in a new world. Suddenly, with no audible herald to announce the advent, English literature found enshrined in it The Rime of the Ancient Mariner, Christabel, though delayed in publication, The Tale of the Dark Ladye, The Nightingale, and KublaKhan-belated like Christabel. Each differs in feeling, thought, tone, rhythm, from the rest; and all agree in being great, sweet, and satisfying. The Ancient Mariner is remarkable for more than its intrinsic merits; it is phenomenal as being from Coleridge. Never was there poet or thinker with a fondness like his for vagueness, ragged ends. Nothing of that is here ; not one incident, nor one emotion, out of season and place ; and the temptations to wandering! An infinite variety of scene, character, impulses, terror, horror, romance, awe, remorse, repentance, hope, disappointment, the blissful calm of Heaven's pardon; and throughout the whole a captivating simplicity!

I know of no poem with more of the divine endowment of never growing out of date; none which possesses more of charm alike for age and youth. The melody of the dirge sung by seraphs in token of forgiveness for the fate of the Mariner's two hundred shipmates, haunts and enchants. It is like balm on an aching wound :

'Twas not those souls that fled in pain,
Which to their corses came again,
But a troop of spirits blest;

For when it dawn'd-they dropp'd their arms, And cluster'd round the mast :

Sweet sounds rose slowly through their mouths, And from their bodies pass'd. 
Around, around, flew each sweet sound,

Then darted to the Sun ;

Slowly the sounds came back again,

Now mix'd, now one by one.

Sometimes a-dropping from the sky

I heard the skylark sing ;

Sometimes all little birds that are,

How they seem'd to fill the sea and air

With their sweet jargoning !

And now 'twas like all instruments,

Now like a lonely flute ;

And now it is an angel's song,

That makes the heavens be mute.

It ceas'd; yet still the sails made on

A pleasant noise till noon,

A noise like of a hidden brook

In the leafy month of June,

That to the sleeping woods all night

Singeth a quiet tune. ${ }^{23}$

Had the Rime stood alone it must have immortalized its writer; but the same year or two which produced it brought to light the earlier and more important portion of Christabel. That is a poem for poets. Yet The Ancient Mariner, which might have been supposed made to compel popular admiration, lay practically still-born until the twin inspiration, printed nineteen years later, called it into acknowledged life. The two resemble one another in nothing except loveliness. The variety which distinguishes Christabel has no affinity to that of its coeval in birth. Every diverse current in The Ancient Mariner sets towards one inevitable end. In Christabel there is no necessity to work in any given direction. Never had a rich and capricious fancy more liberty. Never did apparent trust in chance better justify its independence. Fancy rules; as irresponsible as 
the swaying of a leafy bough. The result is harmony, nevertheless; perfect in its thought, its images, its new and fascinating flexibility of rhythm.

It might almost be thought that the poet was improvising, and as uncertain as his audience of each next musical effect till it came:

It moan'd as near as near can be,

But what it is she cannot tell.-

On the other side it seems to be

Of the huge, broad-breasted, old oak tree.

The night is chill; the forest bare ;

Is it the wind that moaneth bleak ?

There is not wind enough in the air

To move away the ringlet curl

From the lovely lady's cheek-

There is not wind enough to twirl

The one red leaf, the last of its clan,

That dances as often as dance it can,

Hanging so light, and hanging so high,

On the topmost twig that looks up at the sky.

Hush, beating heart of Christabel !

Jesu, Maria ! shield her well!

She folded her arms beneath her cloak,

And stole to the other side of the oak.

What sees she there?

There she sees a damsel bright,

Drest in a silken robe of white,

That shadowy in the moonlight shone;

The neck that made that white robe wan,

Her stately neck and arms were bare ;

Her blue-veined feet unsandal'd were,

And wildly glitter'd here and there

The gems entangled in her hair.

I guess, 'twas frightful there to see

A lady so richly elad as she-

Beautiful exceedingly! 24 
And again the wonderful, changeful melody :

"In the touch of this bosom there worketh a spell,

Which is lord of thy utterance, Christabel !

Thou knowest to-night, and wilt know to-morrow,

This mark of my shame, this seal of my sorrow;

But vainly thou warrest,

For this is alone in

Thy power to declare,

That in the dim forest

Thou heard'st a low moaning,

And found'st a bright lady surpassingly fair ;

And didst bring her home with thee in love and in charity,

To shield her and shelter her from the damp air ". ${ }^{25}$

Christabel and The Ancient Mariner have their several stations ; fixed stars in the empyrean of letters. One is a masterpiece of art, which foils all attempts to detect the secret of its workmanship. The other is so entrancing in its unison of heart and brain, that its captives are never free to inquire whether there be a secret at all. If proof be still wanting of the perfection of Christabel, it is that true criticism has never regretted its incompleteness. Well that it remains a torso incomparable !

I have classed with them three other poems ; and they all deserve their eminence. First must stand the wondrous Vision-like Christabel, a fragment. Execrable, unpardonable, the 'business person from Porlock', who stifled two hundred or more golden dream-lines of Kubla-Khan! A great master of fiction, and a poet too, as we walked up the hill at the foot of which he dwells, once told me that he ranked Kubla-Khan highest among Coleridge's poems. It was a paradox, though so far literally true that the dreamer of such a dream is demonstrated thereby to have had poetry in his very blood!

The melody bubbles, dances, revels, laments, and threatens : 
But oh ! that deep romantic chasm which slanted

Down a green hill athwart a cedarn cover !

A savage place! as holy and enchanted

As e'er beneath a waning moon was haunted

By woman wailing for her demon-lover !

And from this chasm, with ceaseless turmoil seething,

As if this earth in fast thick pants were breathing,

A mighty fountain momently was forced;

Amid whose swift half-intermitted burst

Huge fragments vaulted like rebounding hail,

Or chaffy grain beneath the thresher's flail;

And 'mid these dancing rocks at once and ever

It flung up momently the sacred river.

Five miles meandering with a mazy motion

Through wood and dale the sacred river ran,

Then reach'd the caverns measureless to man,

And sank in tumult to a lifeless ocean;

And 'mid this tumult Kubla heard from far

Ancestral voices prophesying war ! 26

By turns it falls, and, again, rises into an Abyssinian maid's song of Mount Abora, with palaces built of sunshine, over caverns of ice, and yielding delights ineffably seductive and perilous.

A dizzy singing trance! Yet hardly less of common daylight texture than the exquisite Conversational Poem, with its rivalries of many nightingales amid tangled wild woods, interpreted in verse scarcely less honey-sweet than Lorenzo and Jessica's moonlit love ditty :

Far and near,

In wood and thicket, over the wide grove, They answer and provoke each other's song, With skirmish and capricious passagings, And murmurs musical and swift jug jug, And one low piping sound more sweet than allStirring the air with such an harmony, That should you close your eyes, you might almost Forget it was not day! On moonlight bushes, 
Whose dewy leafits are but half-disclosed, You may perchance behold them on the twigs, Their bright, bright eyes, their eyes both bright and full, Glistening, while many a glow-worm in the shade Lights up her love-torch.

A most gentle maid,

Who dwelleth in her hospitable home

Hard by the castle, and knows all their notes, What time the moon was lost behind a cloud, Hath heard a pause of silence ; till the moon Emerging, hath awaken'd earth and sky With one sensation, and those wakeful birds Have all burst forth in choral minstrelsy, As if some sudden gale had swept at once A hundred airy harps! And she hath watch'd Many a nightingale perch giddily

On blosmy twig still swinging from the breeze, And to that motion tune his wanton song, Like tipsy joy that reels with tossing head. ${ }^{27}$

As worthy, still once more, of a place in the hierarchy of song, is the Introduction to the Ballad of The Dark Ladie. The ballad, like Christabel, is a fragment; but the prelude, on the variety of ministers that Love can enlist-even 'a soft and doleful air, an old and moving story '-is as complete in beauty and colour as a rose :

All impulses of soul and sense

Had thrill'd my guileless Genevieve ;

The music and the doleful tale,

The rich and balmy eve ;

And hopes, and fears that kindle hope,

An undistinguishable throng,

And gentle wishes long subdued,

Subdued and cherish'd long !

She wept with pity and delight, She blush'd with love, and virgin shame;

And, like the murmur of a dream,

I heard her breathe my name. 
Her bosom heav'd-she stepp'd aside, As conscious of my look she stepp'dThen suddenly, with timorous eye, She fled to me and wept.

She half inclosed me with her arms, She press'd me with a meek embrace ; And bending back her head, look'd up, And gazed upon my face.

'Twas partly love, and partly fear, And partly 'twas a bashful art, That I might rather feel than see The swelling of her heart. ${ }^{28}$

Coleridge's career as a writer of poetry terminated by the time he was thirty. The body of his poetical work is comprised within three to five years. Had he died in 1802, after the composition of the Ode to Dejection, he would have left the world of poetry as rich as when he finally departed. As a thinker he survived, and reigned, for thirty-two years more. Inspiration ceases for most in middle life. Few, once inspired, cease, while they breathe, from versifying. They versify because verse was wont to be their highest mental medium and instrument. Coleridge, when no longer minded to write Ancient Mariners and Christabels, had an alternative. He remained an intellectual autocrat, and proceeded to utilize his other gift, as a suggester of problems, a setter of texts. If literature cannot be said to have benefited by the soliloquies at Highgate, at least it has gained negatively by the escape through that safety-valve for imagination from the danger of a dilution of poetic greatness. Having tasted of Coleridge's best, we should all of us have been grievous sufferers had we been obliged to put up with aught lower. Better nothing if no more of Christabel, or her peers !

VOL. II 
The Poetical and Dramatic Works of Samuel Taylor Coleridge. Four vols. B. M. Pickering, 1877.

1 Religious Musings, vol. i, pp. 93-4 ; and Lamb to Coleridge, Dec. 10, 1796. Memorials of Charles Lamb, by Talfourd. Moxon, 1850, p. 59.

2 The Eolian Harp, vol. i, p. 158.

3 The Destiny of Nations, vol. i, pp. 189-90.

- Ne Plus Ultra (Sibylline Leaves), vol. ii, p. 281.

5 Ode to the Departing Year, vol. i, p. 176.

- Fears in Solitude, vol. ii, p. 20.

7 The Picture, vol. ii, pp. 107 and 109-10.

${ }^{8}$ Names (Sibylline Leaves), vol. ii, p. 306.

- Fire, Famine, and Slaughter, vol. ii, pp. 132-5.

10 To the Author of the Robbers, vol. i, p. 148.

11 Kosciusko, vol. i, p. 136.

12 Frost at Midnight, vol. ii, p. 9.

13 The Knight's Tomb (Sibylline Leaves), vol. ii, pp. 292-3.

16 A Christmas Carol (Sibylline Leaves), st. 3, vol. ii, pp. 228-9.

15 Epitaph on an Infant, vol. i, p. 73.

${ }^{16}$ Composed on a journey homeward, the Author having received intelligence of the birth of a son, vol. i, pp. 149-50.

17 The Three Graves (Sibylline Leaves), vol. ii, p. 254.

18 The Garden of Boccaccio, vol. ii, p, 327.

19 Ibid., pp. 329-30.

${ }^{20}$ France : an Ode, st. 4, vol. ii, p. 7.

${ }^{21}$ Hymn before Sunrise in the Vale of Chamouni (Sibylline Leaves), vol. ii, pp. 197-8.

${ }_{22}$ Dejection : an Ode (Sibylline Leaves), vol. ii, pp. 220-1.

23 The Rime of the Ancient Mariner, Part v, vol. ii, pp. 45-6.

${ }^{24}$ Christabel, Part I, vol. ii, pp. 66-7.

${ }^{25}$ Ibid., vol. ii, pp. 75-6.

${ }^{26} \mathrm{Kubla}$ Khan; or, a Vision in a Dream, vol. ii, pp. 276-7.

27 The Nightingale : a Conversational Poem, vol. ii, pp. 23-4.

${ }^{28}$ The Ballad of the Dark Ladie, Introduction, vol. ii, pp. 95-6, 


\section{ROBER'T SOU'THEY}

\section{$1774-1843$}

I was brought up to regard Southey as the peer of Coleridge, and Wordsworth, Byron, Shelley, and Keats; not necessarily their equal in degree, but wholly worthy to be ranked among them. As a schoolboy, and as an undergraduate, I read him with respect, in some sort with admiration. When I became entitled to choose College prizes, a collection of his poems was in my list. My contemporaries would not have selected him; they did not think me eccentric for my preference. I have survived to find him utterly out of date, scarcely placed on an upper shelf with the Georgian classics. Even I myself had ceased to read him since my University days, unless when I wished to amuse my children with one of his ballads. Ghosts of old associations seemed to rustle down about me, like last year's leaves from a wind-tossed beech-tree in early spring, as more recently I turned over the many pages to try to discover why his verse was current once, and no longer passes

The tide of neglect even has reached, if not to the full extent, the area of his verse in which he is indisputably a master. Few English poets are his equals, very few his superiors, in humour. Humour various and singular at once. Never mere fun, born with a laugh, and expiring in a yawn. Poetry also, though with sentiment not unbecomingly obtrusive. Above all, an infinite capacity for inventing occasions for itself, though from subject-matter the most unlikely. To give instances out of many as remarkable, the 
opportunity may be supplied by a henpecked Cornishman, whose bride had unfairly taken to the church a bottle of the dominion-ensuring water, which he raced from the altar to be first to drink at the Well of St. Keyne. ${ }^{1}$ It may be the natural anxiety of pious countrymen to secure for their village, by timely preliminaries-such as a deathbed-to Beatification, the relics of a Saint-designate, whom his neighbours might otherwise coax away in life. ${ }^{2}$ A mother's frenzy of anguish for her child devoured by a crocodile suggests a scene of revenge in kind, as equitable as it is irresistibly comic. ${ }^{3} \quad$ A flower of smiling satire springs under the poet's pen from the field of Blenheim, watered with the blood of murdered myriads:

'Why, 'twas a very wicked thing!'

Said little Wilhelmine.

- Nay, nay, my little girl,' quoth he,

'It was a famous victory!' 4

The theme may be a Pope's untold mortal sin, with a Saint's gallop on Satan's own unwilling back to confess and absolve, ${ }^{5}$ or a robber's release from and restoration to his lawful gibbet. 6 Each is made to yield the best of diversion. Half a century ago everybody revelled in the wit of The Devil's Walk!? There were few who had not both shuddered and laughed over Archbishop Hatto and his rats, ${ }^{8}$ and the gallant, futile fight with her registered purchaser, the Arch-Fiend, of The Old Woman of Berkeley in her iron-sealed and chained coffin, hymned and hallowed by fifty Choristers and fifty Priests, with, for sentinels, her son a monk, and her daughter a nun :

In he came with eyes of tlame

The Devil to fetch the dead, And all the Church with his presence glow'd,

Like a fiery furnace red. 
He laid his hand on the iron chains, And like flax they moulder'd asunder, And the coffin lid, which was barr'd so firm, He burst with his voice of thunder.

And he bade the Old Woman of Berkeley rise, And come with her master away:

A cold sweat started on that cold corpse,

At the voice she was forced to obey.

She rose on her feet in her winding-sheet, Her dead flesh quiver'd with fear, And a groan like that which the Old Woman gave Never did mortal hear.

She follow'd her Master to the church door, There stood a black horse there;

His breath was red like furnace smoke, His eyes like a meteor's glare.

The Devil he flung her on the horse, And he leapt up before, And away like the lightning's speed they went, And she was seen no more.

They saw her no more, but her cries For four miles round they could hear, And children at rest at their mother's breast Started, and scream'd with fear. ${ }^{\circ}$

As I now re-read, I do not know which to applaud more, the jester, the story-teller, or the Minstrel. The humour sometimes reminds a little too much of a skull's grin; the art with which it is extracted never fails; we always feel the fine sense of perspective with which the materials are marshalled to yield the desired effect.

But the forgetfulness, which in its course has partially visited the Ballads and Metrical Tales, seems to have washed away, like Lethe, all remembrance of the serious poems. The degree of oblivion I cannot but think unjust, 
and perhaps ungrateful. The mass of Southey's work displays qualities which were appreciated once, and may plead for some recognition still. In the first place his workmanship is excellent; with exceptions, naturally ; especially, of the purveyance of Courtly or patriotic adulation; such as A Vision of Judgment, or the intolerably dreary Pilgrimage to Waterloo. Joan of Arc is a spacious chapter of history, with the rightful proportion, observed with a true instinct, of romance to fact. In the two Madocs, in Wales, and in Aztlan, he had to trust entirely to his fancy, for the general scheme, as well as for details. The whole is harmoniously probable. Roderick, the Last of the Goths, again, is like Joan, an admirable specimen of historical joinery by a romancer with a conscience. Almost everything alleged to have happened had happened, or might have happened. Though liberties are taken with cvents, and their order, the properties are invariably correct, as is the scenery. It is impossible to live in the scveral narratives with their characters, and the sentiments attributed to them, without being the better for the society.

Then, study the couple of Asiatic epics; and admire the intrepidity with which the poet plunges into a new world. Throughout they are picturesque, and gorgeously coloured. Really it is hard for me, while I read, to understand the present coldness towards Arabian Nights Entertainments such as these. Thalaba himself, it may be objected, lacks interest. In that he only resembles many another hero; and the vivacity of his adventures atones. At all events, the same crime cannot be imputed to the characters in the story of Kehama.

It was no ordinary imagination which conjured satisfaction for implacable revengefulness out of a Cain-like brand of security for its abhorred object from every peril to life : 
I charm thy life

From the weapons of strife, From stone and from wood,

From fire and from flood,

From the serpent's tooth,

And the beasts of blood:

From Sickness I eharm thee, And Time shall not harm thee :

But Earth which is mine, Its fruits shall deny thee; And Water shall hear me, And know thee and fly thee;

And the Winds shall not touch thee

When they pass by thee, And the Dews shall not wet thee, When they fall nigh thee;

And thou shalt seek Death

To release thee, in vain ;

Thou shalt live in thy pain

While Kehama shall reign,

With a fire in thy heart, And a fire in thy brain;

And Sleep shall obey me,

And visit thee never,

And the Curse shall be on thee

For ever and ever. ${ }^{10}$

The entire texture approaches the same high standard. All the actors move in an atmosphere of passion. It invests the King of the World, and his victims also. It circulates about the ghastly figure of his dead brutish son. Everything is on a grand scale; from the insatiable ambition of the mighty Rajah; the pursuit of innocent Kailyal by the horrible Spectre, carnal though a ghost, of slain Arvalan; the hall of Royal Death in the peerless palace and gardens,

Where Baly held of old his awful reign; 
to the climax, the storming of Hell itself by the Man-God, the Man-Almighty, his chief and fatal conquest.

Other keys besides the heroic are touched by Southey; the august, the marvellous, and the sordidly criminal, as in the once famous Mary, the Maid of the Inn-a haunting horror. ${ }^{11}$ I fail to recognize the magical reserve, the pensive charm, of Collins's Evening in The First of December :

When Nature shrouds herself, entranced

In deep tranquillity. ${ }^{12}$

Hannah's grave, however, where none

Who trod upon the senseless turf would think

Of what a world of woes lay buried there, ${ }^{13}$

vies with The Parish Register and The Borough in the power to elicit an acrid fragrance from the grime of sin and its sorrow. With a sweet simplicity he welcomes the return of travellers to their home and children. ${ }^{\mathbf{1 4}} \mathrm{He}$ preceded Tennyson in the discovery of the domestic idyll, as The Old Mansion-House testifies. ${ }^{15}$ If only his examples had been fewer, he might have won celebrity for Inscriptions-free at least from their besetting sin of promiscuous adulation-like that imagined for a monument to ruthless Pizarro :

A greater name

The list of Glory boasts not.-Thank the God

Who made thee, that thou art not such as he. ${ }^{16}$

When in the Paradise of his books, it will not be disputed that at least the shadow of inspiration falls upon him :

My days among the Dead are past;

Around me I behold,

Where'er those casual eyes are cast,

The mighty minds of old;

My never-failing friends are they,

With whom I converse day by day. 
With them I take delight in weal,

And seek relief in woe;

And while I understand and feel

How much to them I owe,

My cheeks have often been bedew'd

With tears of thoughtful gratitude.

My thoughts are with the Dead, with them

$I$ live in long-past years,

Their virtues love, their faults condemn,

Partake their hopes and fears,

And from their lessons seek and find

Instruction with an humble mind.

My hopes are with the Dead, anon

My place with them will be,

And I with them shall travel on

Through all Futurity;

Yet leaving here a name, I trust,

That will not perish in the dust. ${ }^{17}$

Even the terrors of Kehama's victims he can lull by reminding of the immortality of Love; of its perfecting in Heaven :

They sin who tell us Love can die.

With life all other passions fly,

All others are but vanity.

In Heaven Ambition cannot dwell,

Nor Avarice in the vaults of Hell ;

Earthly these passions of the Earth,

They perish where they have their birth ;

But Love is indestructible.

Its holy flame for ever burneth,

From Heaven it came, to Heaven returneth ;

Too oft on Earth a troubled guest,

At times deceived, at times opprest,

It here is tried and purified,

Then hath in Heaven its perfect rest;

It soweth here with toil and care

But the harvest time of Love is there. ${ }^{18}$ 
If his right-which I am afraid I have myself not very enthusiastically upheld-to exalted poetical rank is not at present generally acknowledged, the failure arises from no faint-heartedness, or excess of modesty, in him. He has claimed it by work, and even by word. He delighted in the composition of poetry, whether grave or gay, lyric or epic, recondite or simple, even commonplace. Versifying was his recreation, and his solace. His dearest friends were poets. Illustrious members of the brotherhood hailed him as of it. Byron himself, while he jeered, did not deny him a place in the company. Among all his vocations that was the one by which he meant to be recollected; in that,

If but self-approved, to praise or blame

Indifferent, while I toil for lasting fame. ${ }^{19}$

While he had won honours in many fields of literature, the title of poet was the chief distinction he challenged; and how refuse it to the generous, kindly, indefatigable, brave, and honourable man, to the student and scholar, to the creator of Thalaba and Kehama? Clearly we cannot. The fact nevertheless remains that the poems by which he expected to be immortalized are neither read nor honoured. He might have been amused-not surprised-by the knowledge that lines from the Devil's Walk have been incorporated into the language; that every school-girl can tell in verse far from despicable the way in which

the water comes down at Lodore; 20

I do not suppose he would have accepted the compliment as compensation, or been at all better able to explain to himself why posterity should be oblivious of Roderick, Madoc, A Tale of Paraguay, even of Thalaba and Kehama. As I have already intimated, it is indeed difficult to 
account fully for the neglect in its excess. There are reasons on the surface. To begin, I must admit a want of quality, a certain coarseness of fabric, except in Kehama. Again, the bulk is a deterrent, as is the extent of a strange lake to an angler. He may be sure that it contains fish, without being able to tell where they lie. Similarly these vast epics hide valuable ideas, only to be chanced by a reader out of an overwhelming flood of truisms. The interest for others many is alien and remote. From the first it required to be bolstered up by Oriental learning, much of it, in these times of deeper research, musty and rusty. But, in the face of works, some earlier, and more later, which have conquered public favour notwithstanding analogous drawbacks every whit as prejudicial, the poet's spirit might well argue that such attempts at an explanation are insufficient. I do not flatter myself that he would be at all better inclined to accept mine, that the cause is his failure throughout to forge from the furnace within himself a chain of sympathy with his readers. That, however, I believe to be the true one. He seldom seems to touch their and his common human nature. Note how rarely, if ever, his verse makes tears to start to the eyelids. The chill from this absence of mutual glow is positive, palpable, and fatal. Never will the emotions of a poet's readers, charm he never so wisely, take fire unless from the kindling of fuel in the singer's own breast. Southey's Muse was devoid of the passion of sympathy; and his renown suffers in consequence.

He possessed many of the endowments by which admirers are attracted. He was without that which holds them bound. It could not well have been otherwise with a writer who resorted to poetry as a recreation, for rest from the toils of his literary treadmill. He understood 
the art of it, and could call on it, when he chose, to do his bidding. It was his handmaid when it should have been his mistress. A thousand pities! He missed the dearest object of his ambition; and we have lost what might have been, from that richly furnished nature, some inspired strains. As it was, he could not be a great poet ; but he had a lofty soul ; and he was a great man of letters.

The Poetical Works of Robert Southey. Complete in one volume. New edition. Longmans, 1853.

1 The Well of St. Keyne (Ballads and Metrical Tales), p. 448.

2 St. Romuald (Ballads, \&c.), p. 437.

3 The King of the Crocodiles (Ballads, \&c.), pp. 437-8.

4 The Battle of Blenheim (Ballads, \&c.), pp. 449-50.

- The Ballad of St. Antidius, the Pope, and the Devil (Ballads, \&c.), pp. 451-2.

- Roprecht the Robber (Ballads, \&c.), pp. 470-3.

'The Devil's Walk, p. 166-9.

'God's Judgement on a Wicked Bishop (Ballads, \&c.), p. 429.

- The Old Woman of Berkeley (Ballads, \&c.), p. 456.

${ }_{10}$ The Curse of Kehama, Part II, xiv, p. 555.

11 Mary, the Maid of the Inn (Ballads, \&c.), pp. 417-18.

${ }_{13}$ Written on the First of December (Lyric Poems), pp. 120-1.

13 Hannah (English Eclogues), p. 152.

14 The Traveller's Return (Lyric Poems), p. 124.

15 The Old Mansion-House (English Eclogues), pp. 149-50.

${ }_{18}$ For a Column at Truxillo (Inscriptions), p. 172.

${ }^{27}$ My Days among the Dead (Occasional Pieces), sviii, p. 143.

${ }_{18}$ The Curse of Kehama, p. 583.

19 The Poet's Pilgrimage to Waterloo. Proem, st. 21, p. 729.

${ }^{20}$ The Cataract of Lodore (Nondescripts, VII), pp. 164-5. 


\section{SIR WAL'TER SCO'T'T}

\section{$1771-1832$}

Scotr was the least jealous of poets; else, he might have been jealous of himself. His genius dawned upon the world in poetry. As a poet he was recognized before Coleridge, Wordsworth, Byron, Shelley, Keats. Time went on, leaving him at each of its stages more and more eminent and popular. At each his fame in the specific department of poetry manifestly receded. The individuality of the author counts for more in poetry than in any other branch of literature. Never was writer more interesting for himself than Scott. His personal renown practically transferred the Court of Letters from London to Edinburgh. There he reigned, and in his own right always. The particular kind of literature on which the throne rested differed at different periods. It had been romance in metre. It became romance in prose. But the occupant always was King Walter. The poetry survived, though royal no longer. The poems have a hundredfold more readers than when they stirred the envy of the obscure bard of Hours of Idleness. Their claims as poetry have seldom been denied. Yet I am afraid that in general they are valued much less on their own account than on that of the man, and on account of him not so much as a poet as a storyteller.

For romantic fiction on the confines of history, he is indeed no less a master in verse than in prose. In one special department of poetical narration he is supreme. 
I could not lay it down as an absolute condition of excellence in description that the theme shall be one in which the writer has always delighted. But undoubtedly it is added virtue in a poet otherwise well qualified that he loves and has loved it. Scott would have liked to be a soldier. He rejoiced in everything connected with fighting. Never has British poet, except Campbell on more contracted canvases, made the reader equally to feel, as in the Iliad, on a battlefield itself with its turmoil, its frenzy, its ecstasy. He was conscious of his gift, and freely used it.

There is the impress of genuineness on the picture of Bannockburn. Read, for instance, of the final and disastrous English charge over the pit-pitted plain :

Rushing, ten thousand horsemen came,

With spears in rest, and hearts on flame,

That panted for the shock!

With blazing crests and banners spread, And trumpet-clang and clamour dread, The wide plain thunder'd to their tread, As far as Stirling rock.

Down! Down! in headlong overthrow, Horsemen and horse, the foremost go,

Wild floundering on the field!

The first are in destruction's gorge, Their followers wildly o'er them urge :The knightly helm and shield, The mail, the acton, and the spear, Strong hand, high heart, are useless here ! Loud from the mass confused the cry Of dying warriors swells on high, And steeds that shriek in agony! They came like mountain-torrent red, That thunders o'er its rocky bed; They broke like that same torrent's wave, When swallowed by a darksome cave, 
Billows on billows burst and boil, Maintaining still the stern turmoil, And to their wild and tortured groan Each adds new terrors of his own ! ${ }^{1}$

Lifelike, again, is the glimpse of a later battle-Flodden -as fitfully descried by Marmion's Squires from a neighbouring hill-top :

They close, in clouds of smoke and dust, With sword-sway, and with lance's thrust :

And such a yell was there,

Of sudden and portentous birth, As if men fought upon the earth, And fiends in upper air ;

$O$ life and death were in the shout, Recoil and rally, charge and rout, And triumph and despair.

At length the freshening western blast Aside the shroud of battle cast ; And, first, the ridge of mingled spears Above the brightening cloud appears; And in the smoke the pennons flew, As in the storm the white seamew; Then mark'd they, dashing broad and far, The broken billows of the war, And plumèd crests of chieftains brave, Floating like foam upon the wave;

But nought distinct they see;

Wide raged the battle on the plain ; Spears shook, and falchions flash'd amain;

Fell England's arrow-flight like rain ;

Crests rose, and stoop'd, and rose again, Wild and disorderly. ${ }^{2}$

All the incidents of warfare inflamed his Muse; if not a clash of battalions, an armed and perilous ambush. The blood stirs at the sudden apparition from heather and bracken of 'Clan Alpine's warriors true': 
Wild as the scream of the curlew, From crag to crag the signal flew. Instant, through copse and heath, arose Bonnets and spears and bended bows; On right, on left, above, below, Sprung up at once the lurking foe; From shingles gray their lances start, The bracken bush sends forth the dart, The rushes and the willow-wand Are bristling into axe and brand, And every tuft of broom gives life To plaided warrior arm'd for strife. That whistle garrison'd the glen At once with full five hundred men, Watching their leader's beck and will, All silent there they stood, and still. ${ }^{3}$

He was an equally glad interpreter of the pibroch of Donald Dhu, and of the proscribed and hunted Macgregor's owl's hoot :

Our signal for fight that from monarchs we drew, To be heard but by night in our vengeful haloo. ${ }^{4}$

In his case direct and long personal sympathy, not merely with the subject in general, but with its particular exemplifications, was virtually indispensable. Art for him did not supply its place in the least. Without it he is diffuse and dull. The spectacle, or expectation, of an exchange of hard blows had an aptitude for exciting his inspiration; but he had to be personally interested before even a pitched battle made a poem. Everything else-story-telling itself -is an accident in his poetry, except the personal emotion; and that responded fortunately to other themes besides arms. Touch the key, in his rich memory, of an ancient legend, an historic edifice; and lovely music pours forth. Nowhere has minster, from the glory of its prime to eloquent decay, revealed itself to an insight more delicate 
and sympathetic than Melrose to his fancy bridging, as with a rainbow, four hundred years :

If thou would'st view fair Melrose aright,

Go visit it by the pale moonlight ;

For the gay beams of lightsome day

Gild, but to flout, the ruins gray.

When the broken arches are black in night,

And each shafted oriel glimmers white;

When the cold night's uncertain shower

Streams on the ruin'd central tower ;

When buttress and buttress, alternately,

Seemed framed of ebon and ivory;

When silver edges the imagery,

And the serolls that teach thee to live and die ;

When distant Tweed is heard to rave,

And the owlet to hoot o'er the dead man's grave,

Then go-but go alone the while-

Then view St. David's ruin'd pile ;

And, home returning, soothly swear,

Was never scene so sad and fair ! ${ }^{\circ}$

His mind was a treasure-house of tradition and romance from which a poet's magic conjured up memorial funeral rites for drowned Rosabelle in the ancestral mausoleum :

O'er Roslin all that dreary night

A wondrous blaze was seen to gleam;

'Twas broader than the watch-fire's light,

And redder than the bright moon-beam.

It glared on Roslin's castled rock,

It ruddied all the copse-wood glen,

'Twas seen from Dryden's groves of oak,

And seen from cavern'd Hawthornden.

Seem'd all on fire that chapel proud,

Where Roslin's chiefs uncoffin'd lie,

Each Baron, for a sable shroud,

Sheathed in his iron panoply.

VOL. II 
Seem'd all on fire, within, around, Deep sacristy, and altar's pale, Shone every pillar foliage-bound, And glimmer'd all the dead men's mail.

Blazed battlement and pinnet high, Blazed every rose-carved buttress fair-

So still they blaze, when fate is nigh

The lordly line of high St. Clair.

There are twenty of Roslin's barons bold

Lie buried within that proud chapelle :

Each one the holy vault doth hold-

But the sea holds lovely Rosabelle ! 6

And it was a poet's tyrant imagination in the grasp of the past, which was needed to steel his heart for that tale of horror, the accurst monastic conclave in the murder-den of Holy Island, which makes one cry out upon the Fiend for not sparing perjured Marmion

\section{but a day}

For wasting fire, and dying groan,

And priests slain on the altar-stone. ${ }^{7}$

I have left to the last that which might at once, and by itself, have established the Border Minstrel's title to a poet's laurel. Surely in the front rank of requiems stands that over Pitt and Fox. The two Titanic figures had filled the entire horizon of Scott's youth and early manhood; and the passion of his verse testifies to the impress on his nature. Yet never, like many of its class, does it foam into rhetoric, or rave into hysterics. It rises and falls like tidal waves. As the thought dwells on the broken health, and broken heart, of the mighty Minister the melody is solemn and sad :

Had'st thou but liv'd though stripp'd of power,

A watchman on the lonely tower,

Thy thrilling trump had roused the land,

When fraud or danger were at hand ; 
By thee, as by the beacon-light,

Our pilots had kept course aright;

As some proud column, though alone,

Thy strength had propp'd the tottering throne;

Now is the stately column broke,

The beacon-light is quench'd in smoke,

The trumpet's silver sound is still,

The warder silent on the hill ! 8

The dirge grows triumphal as it unites him and his rival in a common bond of renown and patriotism :

With more than mortal powers endow'd,

How high they soar'd above the crowd !

Theirs was no common party race,

Jostling by dark intrigue for place ;

Like fabled gods, their mighty war

Shook rcalms and nations in its jar ;

Beneath each banner proud to stand,

Looked up the noblest of the land,

Till through the British world were known

The names of Pitt and Fox alone.

Spells of such force no wizard grave

E'er framed in dark Thessalian cave.

These spells are spent, and, spent with these,

The wine of life is on the lees;

Genius, and taste, and talent gone,

For ever tomb'd beneath the stone,

Where-taming thought to human pride!-

The mighty chiefs sleep side by side.

Drop upon Fox's grave the tear,

'Twill trickle to his rival's bier;

O'er Pitt's the mournful requiem sound,

And Fox's shall the notes rebound.

The solemn echo seems to ery-

'Here let their discord with them die.

Speak not for these a separate doom,

Whom Fate made Brothers in the tomb;

And search the land of living men,

Where wilt thou find their like agen ?' 9 
Throughout Scott's poems blemishes and defects abound without clouding his title to a poet's honours. He dilutes his descriptions often, and is careless in diction. Very seldom did he use pruning hook or file. No poet could bs more slipshod. Much in the longer compositions may be fair story-telling, and is sure to be archaeologically instructive. It may even reach the level of a popular ballad. Assuredly it is not poetry. The facility, proverbially fatal, of the octosyllabic metre lured him into prolixity. Wide reading in many directions, and a memory for particular subjects practically boundless, contributed to tempt him to improvise. As he freely admitted, he was without the faculty of self-criticism. It is an invaluable incapacity during the process of poetical production; a very dangerous one in the subsequent period of reflection and revision. Among the results was that he accepted unsuspiciously whatever subject happened to present itself. For any, and especially for a metrical, story it is essential that the plot should possess enough intrinsic and glowing interest to stimulate reader and writer alike. With three he was fortunate. As mere tales The Lay of the Last Minstrel, Marmion, and the Lady of the Lake, fascinate. Bannockburn is not intimately enough connected with Bruce's wanderings among the Isles to lend adventures among them retrospective animation. Very few of the present generation have patience to trace the maze of Rokeby. In consequence a fine piece of character-drawing in Bertram, with his audacious escapes and death, has been wasted. The Bridal of Triermain, a bright garden of fancies, with its Arthurian atmosphere, is no more than a name, if that. Merlin would have to come to life again to revive it, or, in spite of the flood of grand rushing verse, Harold the Dauntless. 
Happily the three finest Epic-Ballads, or Ballad-Epics, in the language have outlived the discoverer, or rediscoverer, of the type, with no symptom about them of impending torpor or trance. To bear them company they maintain a body-guard of intimate preludes, and isolated bursts of music. Glenfinlas, The Eve of St. John, re-incarnations of Border Minstrelsy, re-inspired imitations of mystic German, and a spray of lyrics and dramatic fragments, are of the number. Scott, at his best, that is, when the subject has its source in his heart, soars upwards; his whole nature is led captive by the poetic spirit; all his powers are evidently its tributaries or ministers. The sagacity, humour, painstaking, wisdom, in which, while treading earth, he excelled, throw into clearer relief the ecstasy of the winged mood of inspiration. Like his poctic fellows he had the instinct which, when itself captivated, pounces instantly upon the precise details required, upon the one virgin plot of earth fit for the imagination to cultivate. No Lowlander or Borderer before him had discovercd romance in a Highland cateran. Who does not, even to excess, recognize it now? Every great poet is a pioneer. Wordsworth was one; and such, though in older soil, was Scott. In the quality, and the energy to exercise it, he resembled his kind; the specific line he followed was peculiarly his own, as were the weapons he employed.

$\mathrm{He}$ is an open-air poct, a poet of morning, not of night. In his most vehement dithyrambs he says outright what he means. Trickery he disdained. He never hunted after conceits. It is easy to understand how Ruskin, not being wholly free from them himself, should have loved to aerate his disciples' souls and his own with poetry like Scott's, where there are few or none. Some poetry is itself essence, a distillation of thought, of conclusions, from the writer's 
mind. There is a sort, and Scott's is of it, in which the reader has to distill for himself. The poet has collected, selected the materials; has himself been enraptured by the feeling, rather than expression, of their essence. It is the fault of his public if it cannot be so likewise. The inclination of the present age is towards having introspection and intellectual analysis done for it, and by its poets. To poetry it looks for problems, and for the solutions. Scott does not deal in enigmas. In him it would have been affectation; and he is never affected. As he never poses as a Sphinx, so he pretends neither to be a child of nature, like Burns, nor a nature worshipper, like Wordsworth. Yet his scenes are all, in their changeful diversity, constantly true and real. He does not attempt to hide his debt to libraries for very much in his narratives. He makes no parade of the equal truth that he has charmed the heart out of them; that in his verse it beats as it rarely beat before.

No golden haze floats over the poems of Scott. They apply no form of spiritual or sensuous intoxication. Only, when the imagination is elsewherc cloyed with sweetness, or has wearied of tying knots in the brain, when it longs for dancing breezes and fire, like the Homeric, it turns with relief to the Last Minstrel's Lay, to Marmion, to The Lady of the Lake. They re-enter into their rightful inheritance of hearthside favour. When they are duly understood, it will be seen also that they can reclaim something of worth as high; that is, property in the author himself. Scott the man is a possession that any province of literature may be proud to appropriate as primarily its own. Nobody can be surprised that the title to such a prize has at times been disputed. Those splendid gifts, the manliness, the magnanimity, the incapability of 
envy, jealousy, meanness, unkindness, the freshness, the genius which extracted gold from everything, and transmuted lead into gold, the large presence in letters and in life, which ennobled both-were they the poet's or the story-teller's more legitimate attributes? Study the poems; and you will find the basis of all there.

Never in writer was there less of egotism; yet never poet was more assured that poetry was his vocation. $\mathrm{He}$ continued in the full practice of the art as long as inspiration, with the rarest exceptions, denied by many to be exceptions, is wont to descend. For its sake he had sacrificed professional ambition; he had curbed the aspirations of romance, and bidden it take second place. There it waited a humble attendant, until poetry voluntarily abdicated, when it pressed forward to occupy and console. But the poetic spirit dwelt apart; it had not died. It is felt, feeding, guiding, lending warmth and grace to fiction, always prepared to step forth from its retirement at need; -like Achilles, behind the borrowed shield of Ajax, scaring with his battle-cry the wolves of Troy from the body of Patroclus.

The Poetical Works of Sir Walter Scott, ed. J. G. Lockhart. 12 vols. Edinburgh : 1833-4.

1 The Lord of the Isles, Canto vi, st. 24.

2 Marmion, Canto vi, stanzas 25-26.

3 The Lady of the Lake, Canto v, st. 9.

4 Macgregor's Gathering.

5 The Lay of the Last Minstrel, Canto ii, st. 1.

- Ibid., Canto vi, Song 23.

7 Marmion, Canto vi, st. 31.

s Ibid., Introduction to Canto i.

I Ibid. 


\section{JAMES HOGG}

\section{$1770-1835$}

A POET, a born poet, and nothing but a poet; a poet all over, who thought in poetry; with whom all he saw turned to poetry; who wrote much verse, read formerly, and still, if at all, with pleasure; who had the aspirations of a great poet, perhaps, the belief that he was one; who yet was never recognized as more than a minor poet; and never, with a single exception, wrote other than minor poetry.

Not that his copious poetical repertory is without abundant testimony to a rich and ready fancy. He is at home in Fairyland. The Haunted Glen, in which the Elves are to meet to crown for King a mortal man refined into their nature by seven years of penance, is full of delicate imaginings. The monarch elect renames his attendant sprites, as in its model A Midsummer Night's Dream, where a grosser creature discharges the same function. So dainty here is the texture that, in fear of coming upon coarser threads, we have a sense of relief when the fabric is left incomplete with a dismissal of the little beings to their several duties. Still more musical, as voiced in Ettrick dialect, is the appeal to the fairies to watch over a newborn babe. Humour everywhere in Hogg bubbles up freely, though nowhere more delightfully than in the tragicomedy of The Gude Greye Katt. No feeling heart can help compassionating the sad plight of the great Byschope of Blain, who for toying with the beauteous witch he had 
been invited to unmask and ban, finds himself suddenly in Mistress Pussy's claws taking aghast

his jante

Up throu the milkye waye. ${ }^{1}$

There is store as well of humour's sister, real pathos; from the elegy on the nameless child, whose

little feet across the lawn

Scarce from the primrose pressed the dew ;

I thought the Spirit of the Dawn

Before me to the greenwood flew ; ${ }^{2}$

to Poor Little Jessie's lament :

It's lang sin' I lost baith my father and mother,

I'm simple an' poor, an' forlorn on the way:

I had ane that I likit, an only dear brother,

My Willie-but he 's lying eauld on the clay. ${ }^{3}$

Even the 'old house,' deserted by the thriving, aged farmer, has its tribute of pretty pity:

Thy roof will fa', thy rafters start,

How damp an' cauld thy breath will be !

$\mathrm{Ah}$, sae will soon ilk honest heart,

That erst was blithe an' bauld in thee.

Fareweel my house an' burnie clear,

My bourtree bush an' bowzy tree,

The wee while I maun sojourn here

I'll never find a hame like thee. ${ }^{4}$

And he can sing too, Burns-like, just for singing's sake, as of Peggie,

\section{the fairest flower}

The braes of Ettrick ever saw, ${ }^{5}$

and of the blissful hour,

When the little wee bit heart

Rises high in the breast, An' the little wee bit starn

Rises red in the east. 
O there's a joy sae dear, That the heart can hardly frame, Wi' a bonny, bonny lassie, When the kye comes hame, When the kye comes hame, 'Tween the gloaming and the mirk, When the kye comes hame. ${ }^{6}$

The possibilities of charm in all real poetry are infinite. Whenever we look close at verse by a genuine poet, of high or low degree, a temptation, as here, to exaggerate merit naturally arises. Standing a little farther off, I see defects pervading the entire body of Hogg's verse. Not merely do they affect windy effusions, like Mary Lee of Carelha, the tiresome imitations of contemporary writers in The Poetic Mirror, the echoes, not confessed imitations--as is Busaco, of Hohenlinden-the glib, false sentiment of Cary O' Kean, and the mediocrity of the Sacred Melodies; they are not absent even from the pieces I have selected to show the poet at his best. It is not only, or mainly, a rawness both of material and of workmanship, a dearth of mellowness and finish. The quality which I chiefly miss is poetic rapture, with the consequent glow of sympathy between reader and author. A poem with those properties will leave behind in the reader's soul something of itself, which draws him back to it with ropes, whether of silk or of steel. Here I admire, think how clever it all is, how beautiful some parts-and retain nothing. The flood has swept over the surface of my mind, and is gone.

I fear I can make no large exception, none in favour even of the Gude Greye Katt, for which I keep a soft place in my heart. My objection applies to the bulk of The Queen's Wake itself, on which, as a whole, the survival of the Shepherd's reputation principally depends. 
The preambles to its various tales generally are excellent; for in them he forgets to be aught but himself, the boy,

Who on Ettrick's mountain green

In nature's bosom nursed had been.?

Two or three beautiful songs are interspersed ; in particular, The Spectre's pathetic Cradle Song :

Hush, my bonny babe !-hush, and be still !

Thy mother's arms shall guard thee from ill;

Far have I borne thee in sorrow and pain,

To drink the breeze of the world again.

The dew shall moisten thy brow so meek,

And the breeze of midnight fan thy cheek;

And soon shall we rest in the how of the hill-

Hush, my bonny babe!-hush, and be still $!^{8}$

In the tales themselves, with one delightful exception, I do not rate the quality above Hogg's usual average. All suffer from his common weakness of too easy contentment with his work; of excessive and unpruned metrical facility. For instance, consider the preposterous length of the fourteenth bard's ballad, otherwise captivating, of Mary Scott! Such productions are to the higher poetry something such as Memoires pour servir are to history. They suggest a poet in the making rather than made.

Only once does Hogg appear to me to have undergone a fit, no mere transient spasm, of the rapture which communicates itself to a poet's public. In Kilmeny, if nowhere else, he is inspired. That is among the poems which, having been once actually taken into the mind, remain possessions, and in possession. It has growth in it, and atmosphere. If there is something also of glorious unreason in the choice of sweet Kilmeny for a semi-earthly, semi-ethereal immortality, the extravagance is without offence. 
As we read of her beautiful childhood, her vanishing, her loving reappearance in that which was felt to be no longer her ain countrye, how she sojourned briefly among her kinsfolk, a waking dream, and finally dissolved again into a celestial memory, we are sensible of no violence; we are in the poet's hands, and are content to be there :

Bonnie Kilmeny gaed up the glen; But it wasna to meet Duneira's men;

It was only to hear the yorlin sing, And pu' the cress-flower round the spring; For Kilmeny was pure as pure could be. But lang may her minny look o'er the wa', And lang may she seek the green-wood shaw ; Lang the laird o' Duneira blame, And lang, lang greet or Kilmeny come hame ! When many lang days had come and fled, When grief grew calm, and hope was dead, When mess for Kilmeny's soul had been sung, When the bedesman had prayed, and the dead bell rung; Late, late in a gloamin' when all was still, When the fringe was red on the westlin hill, The wood was sere, the moon i' the wane, The reek o' the cot hung over the plain, Like a little wee cloud in the world its lane ; When the ingle lowed wi' an eiry leeme, Late, late in the gloamin' Kilmeny came hame !

'Kilmeny, Kilmeny, where have you been ? Lang hae we sought baith holt and dean.' Kilmeny looked up with a lovely grace, But nae smile was seen on Kilmeny's face ; As still was her look, and as still was her ee, As the stillness that lay on the emerant lea; Or the mist that sleeps on a waveless sea. For Kilmeny had been she ken'd not where, And Kilmeny had seen what she could not declare; Kilmeny had been where the cock never crew, Where the rain never fell, and the wind never blew, 
But it seemed as the harp of the sky had rung, And the airs of heaven played round her tongue, When she spake of the lovely forms she had seen, And a land where sin had never been,

$A$ land of love and a land of light

Withouten sun, or moon, or night ;

Where the river swa'd a living stream, And the light a pure and cloudless beam ;

A land of vision it would seem, A still, an everlasting dream.

In yon green-wood there is a waik, And in that waik there is a wene, And in that wene there is a maik, That neither has flesh, blood, nor bane ; And down in yon green-wood he walks his lane. In that green wene Kilmeny lay, Her bosom happ'd wi' flowerets gay ; But the air was soft and the silence deep, And bonnie Kilmeny fell sound asleep. She kenn'd nae mair, nor open'd her e'e. Till waked by the hymns of a far countrye.

She 'waken'd on a couch of the silk sae slim, All striped in the bars of the rainbow's rim; And lovely beings round were rife, Who erst had travell'd mortal life.

They clasp'd her waist and her hands sae fair, They kiss'd her cheek and they kemed her hair, And round came many a blooming fere, Saying, 'Bonnie Kilmeny, ye're welcome here! Now shall the land of the spirits see, Now shall it ken what a woman may be. Many a lang year, in sorrow and pain, Many a lang year through the world we've gane, Commission'd to watch fair womankind, For it 's they who nurice th' immortal mind. 0 , sweet to Heaven the maiden's prayer, And the sigh that heaves a bosom sae fair ! And dear to Heaven the words of truth, And the praise of virtue frae beauty's mouth! 
O bonnie Kilmeny! free frae stain,

If ever you seek the world again,

That world of sin, of sorrow, and fear,

0 tell of the joys that are waiting here.'

They lifted Kilmeny, they led her away, And she walk'd in the light of a sunless day;

The sky was a dome of crystal bright,

The fountain of vision, and fountain of light ;

The emerald fields were of dazzling glow,

And the flowers of everlasting blow.

Then deep in the stream her body they laid,

That her youth and beauty never might fade ;

And she heard a song, she heard it sung,

She kenn'd not where ; but sae sweetly it rung,

It fell on the ear like a dream of the morn ;

' $O$ blest be the day Kilmeny was born!

Now shall the land of the spirits see,

Now shall it ken what a woman may be!'

They bore her away, she wist not how,

For she felt not arm nor rest below ;

But so swift they wain'd her through the light,

'Twas like the motion of sound or sight,

Unnumbered groves below them grew,

They came, they pass'd, and backward flew,

Like floods of blossoms gliding on,

In moment seen, in moment gone.

But to sing the sights Kilmeny saw,

So far surpassing nature's law,

The singer's voice wad sink away,

And the string of his harp wad cease to play.

But she saw till the sorrows of man were bye,

And all was love and harmony ;

Till the stars of heaven fell calmly away,

Like flakes of snaw on a winter day.

Then Kilmeny begg'd again to see

The friends she had left in her ain countrye;

To tell of the place where she had been,

And the glories that lay in the land unseen; 
To warn the living maidens fair,

The loved of Heaven, the spirits' care,

That all whose minds unmeled remain

Shall bloom in beauty when time is gane.

With distant music, soft and deep, They lull'd Kilmeny sound asleep ; And when she awaken'd, she lay her lane, All happ'd with flowers, in the green-wood wene.

When seven lang years had come and fled, When grief was calm, and hope was dead; When scarce was remember'd Kilmeny's name, Late, late in a gloamin' Kilmeny came hame !

When a month and a day had come and gane, Kilmeny sought the green-wood wene; There laid her down on the leaves sae green, And Kilmeny on earth was never mair seen. But $\mathrm{O}$, the words that fell from her mouth Were words of wonder and words of truth ! But all the lands were in fear and dread, For they kendna whether she was living or dead. It wasna her hame, and she couldna remain ; She left this world of sorrow and pain And return'd to the land of thought again ! 9

Never was Fairy-land made to appear nearer to us, or suffused with lovelier colours. Had the Shepherd of Ettrick Glen earlier told to the world his vision of Kilmeny, Scott, with all his friendly prudence, would not have counsell'd the silencing of

the fond aspiring song.

Aware of such a potentiality within him, if seldom elsewhere developed to equal perfection, Hogg himself may be forgiven for soreness of heart at the wounding wisdom of worldly experience : 
Blest be his generous heart for aye !

He told me where the relic lay :

Pointed my way with ready will,

Afar on Ettrick's wildest hill ;

Watch'd my first notes with curious eye,

And wonder'd at my minstrelsy ;

He little ween'd a parent's tongue

Such strains had o'er my cradle sung.

But when to native feelings true,

I struck upon a chord was new ;

When by myself I 'gan to play,

He tried to wile my harp away.

Just when her notes began with skill,

To sound beneath the southern hill,

And twine around my bosom's core,

How could we part for evermore ?

'Twas kindness all-I cannot blame-

For bootless is the minstrel flame :

But sure a bard might well have known

Another's feelings by his own! ${ }^{10}$

It was natural for him to fancy that in happier circumstances, with more sympathy from without, he had it in him to rank with his many illustrious contemporaries. Yet I am afraid that, if Kilmeny, though certainly no accident, stands alone among his works, the default was rather in himself than in others; that, if his soul held the germs of new Kilmenys, the will was wanting to endure in patience the pangs of bringing them forth, equipped to soar and sing.

The Poetical Works of James Hogg. Four vols. Edinburgh : Arch. Constable, 1822. Also: Poems and Life of the Ettrick Shepherd. New Edition. By the Rev. Thomas Thomson. London: Blackie, 1865.

1 The Gude Greye Katt (The Poetic Mirror).

\& Elegy (Miscellaneous Poems).

Poor Little Jessie (Songs).

4 The Auld Man's Fareweel to his Wee House (Miscellaneous Poems). 


\section{JAMES HOGG}

- Blithe an' Cheerie (Songs).

- When the Kye comes Hame (Songs).

' Tenth Bard's Preamble (The Queen's Wake).

- Ibid., The Spectre's Cradle Song (Queen's Wake).

9 Thirteenth Bard's Song-Kilmeny (Queen's Wake).

10 Ibid., The Qucen's Wake-Conclusion. 


\section{WALTER SAVAGE LANDOR}

\section{$1775-1864$}

A POET with greatness in him; who has written unforgettable things. Illustrious in prose as in verse; but always a poet. As a poet, a success and a failure.

To begin with a theme by which he would himself have chosen to be judged-in his metempsychosis as a Greek poet he works miracles. Study Enaleos and Cymodameia, Pan and Pitys, Cupid and Pan, Europa and her Mother, Chrysaor, The Altar of Modesty. The outlines are exquisitely clear, never out of drawing ; the grace, if sometimes marble-cold, is finely statuesque. Now and again, the warm, living, modern blood asserts itself in him ; and the figures are suffused with pathos. Even then, if not Greek, neither are they crudely Gothic. The blend is beautifully tempered in The Hamadryad; in Peleus and Thetis ; in the first part of Corythos ; in the coquetting with her peasant wooer of the sweet wood-nymph, who, as any human maid, knew that

$$
\text { to play at love, }
$$

Stopping its breathings when it breathes most soft,

Is sweeter than to play on any pipe $;^{1}$

and in that masterpiece, Iphigeneia and Agamemnon, with the final heroic tenderness of the victim:

An aged man now enter'd, and without

One word, stept slowly on, and took the wrist

Of the pale maiden. She lookt up, and saw The fillet of the priest and calm cold eyes.

Then turn'd she where her parent stood, and cried

' $O$ father! grieve no more; the ships can sail.' 2 
In another as admirable, The Espousals of Polyxena, the melancholy deepens into remorseless tragedy ; all is frankly Hellenic. It is not often that insular fancy runs insolently wild, as in Achilles and Helena on Ida. For the most part the self-restraint is as admirable as the vivacity. It distinguishes itself particularly in the brave repulse of temptations to measure ancient virtue by modern canons. Landor's sense of consistency is incorruptible by sentiment. He dismisses the ghost of Achilles with a legacy of vindictiveness against the House of Priam, without a word of pity for its child, his affianced, most innocent bride, whom none

Heeded, tho' sinking as if into death. ${ }^{3}$

The same fidelity to artistic duty pervades the Acts and Scenes from Roman and modern history.

Occasionally, it may be admitted, he somewhat abuses his liberty when he is given or assumes a free hand, as in the tyrannicidal scene between Tyrrel and Rufus, and in the thrilling description of Beatrice Cenci's execution :

Men have been brave, but women have been braver! ${ }^{4}$

In general he keeps his footing firmly over medieval and classical quagmires. He does not pretend to set history right when, as if with intention, it has wrapt in darkness personalities like those of Count Julian and Queen Giovanna. Readers might sometimes wish that he had indulged a little at times in anachronistic sentimentality. We feel a shock, as in the presence of a cruel action, at the brutish exultation of King Henry, as he hears on Richmond Chase Anne Boleyn's 'knell from Paul's' :

How sweetly that bell warbled o'er the water $!^{5}$

It must have required all even of his courage to print the F 2 
scene between young Caesarion and the murderous hireling, Scopas. High dramatic skill in the analysis of emotions but just renders it endurable; and all the admiration students must feel for a consummate artist is needed to earn his pardon for the torture he inflicts upon them.

Genius owes it to itself, to the world, to show the utmost it can do, to set itself difficult tasks, to climb high peaks which lead nowhere, for the attainment of ends apparently profitless. Rightly it is accounted an unworthy thing to be content with easy, dazzling effects. Trusting to its untried capabilities, it often leaps without measuring width or depth. Sometimes it attempts the impracticable. I have no doubt but that Landor, who acted loyally up to the obligations his great powers laid upon him, reckoned the Hellenics, and Acts and Scenes, his foremost achievements in poetry. He judged aright, I believe, of the former, if not of the latter. Unhappily, the public of fair intelligence scarcely agreed with the author in his lifetime, and agrees yet less now. Its error, as I consider the neglect, has contributed to a second and costlier one. It has involved a multitude of pieces possessed of every title to popularity, except the fact.

Landor tells a story as few poets can. Witness the charming tale of the hapless love of Guidone and Lucia. Never was there a more righteous critic; yet with what charm in confessing and excusing faults in those whom, like Catullus, he loves :

\section{Yes, in Thalia's son}

Such stains there are-as when a Grace

Sprinkles another's laughing face

With nectar, and runs on $!^{6}$

Never was there one more delicately discriminating, more 
signally without malignity or jealousy; for it seemed to him an act of high justice to condemn Young :

Thou dreariest droll of puffy short-breath'd writers ! ?

But first and foremost of his gifts is that he can sing. In the collection of 1846 there is a wreath of songs which it would be hard to match. Add to them from later volumes; and we shall still discover fresh and fresh irresistible candidates for admittance to the sisterhood.

Whenever I recommence turning over the pages, I come upon another, and yet another, that cannot be denied. They represent among them all kinds of qualities. A lover of poetry must be difficult to please who does not find an example anywhere to suit his taste, though the poet's own favourite lyrical mood, which personally he belied, is an appealing melancholy. Observe the feathery touch, the variety, the piquancy; and guess-they are not too intricate-the sweet conundrums set in delicious music :

Here, ever since you went abroad,

If there be change, no change I see,

I only walk our wonted road,

The road is only walkt by me.

Yes; I forgot; a change there is ;

Was it of that you bade me tell ?

I catch at times, at times I miss

The sight, the tone, I know so well.

Only two months since you stood here!

Two shortest months! then tell me why

Voices are harsher than they were,

And tears are longer ere they dry. ${ }^{8}$

Twenty years hence my eyes may grow

If not quite dim, yet rather so,

Still yours from others they shall know

Twenty years hence. 


\section{THE POETS}

Twenty years hence, tho' it may hap

That I be call'd to take a nap

In a cool cell where thunder-clap

Was never heard,

There breathe but o'er my arch of grass

A not too sadly sigh'd 'Alas!'

And I shall catch, ere you can pass

That wingèd word. ${ }^{9}$

Loved, when my love from all but thee had flown, Come near me ; seat thee on this level stone ; And, ere thou lookest o'er the churchyard wall, To catch, as once we did, yon waterfall, Look a brief moment on the turf between, And see a tomb thou never yet hast seen. My spirit will be sooth'd to hear once more 'Good-bye' as gently spoken as before. ${ }^{10}$

There are sweet flowers that only blow by night, And sweet tears are there that avoid the light; No mortal sees them after day is born, They, like the dew, drop trembling from their thorn. ${ }^{11}$

Very true, the linnets sing Sweetest in the leaves of spring ; You have found in all these leaves That which changes and deceives, And, to pine by sun or star, Left them false ones as they are. But there be who walk beside Autumn's till they all have died, And who lend a patient ear To low notes from branches sere. ${ }^{12}$

Ah what avails the sceptred race, Ah what the form divine! What every virtue, every grace ! Rose Aylmer, all were thine. 
Rose Aylmer, whom these wakeful eyes

May weep, but never see,

A night of memories and of sighs

I consecrate to thee..$^{13}$

The leaves are falling; so am I ;

The few late flowers have moisture in the eye ;

So have I too.

Scarcely on any bough is heard

Joyous, or even unjoyous, bird

The whole wood through.

Winter may come ; he brings but nigher

His eircle (yearly narrowing) to the fire

Where old friends meet;

Let him ; now heaven is over-cast,

And spring and summer both are past,

And all things sweet. ${ }^{14}$

Mother, I cannot mind my wheel ;

My fingers ache; my lips are dry;

$\mathrm{Oh}$, if you felt the pain I feel!

But oh, who ever felt as I !

No longer could I doubt him true ;

All other men may use deceit ;

He always said my eyes were blue,

And often swore my lips were sweet.15

And, lastly :

Is it no dream that I am he

Whom one awake all night

Rose ere the earliest birds to see,

And met by dawn's red light;

Who, when the wintry lamps were spent,

And all was drear and dark,

Against the rugged pear-tree leant

While ice crackt off the bark ;

Who little heeded sleet and blast,

But much the falling snow;

Those in few hours would sure be past,

His traces that might show ; 
Between whose knees, unseen, unheard,

The honest mastiff came,

Nor fear'd he ; no, nor was he fear'd ;

Tell me, am I the same ?

O come ! the same dull stars we'll see,

The same o'erclouded moon.

$\mathrm{O}$ come ! and tell me am I he ?

$\mathrm{O}$ tell me, tell me soon. ${ }^{16}$

Are they not, one and all, magical ? Yet these nine are only specimens of a host, including, perhaps, others for many minds lovelier still. It has cost me labour and pain to try to account by examples for the homage I have rendered to their singer, when, I daresay, it could have been justified as adequately by a couple of lines :

I loved him not; and yet now he is gone,

I feel I am alone.

Strange, that a multitude of the like should not be household words! What irony of literary fate that the poet's name should be inscribed among the highly honoured in English literature, and his poems remain, unless for a small minority, virtually a sealed book !

He has met with a doom analogous to that designed by St. Romuald's votaries-in a ballad to which I recently referred-for their holy townsman. He has been sanctified by a premature death. While he ought to be still living and read, he has been elevated into the dignified repose of a classic. Contrasted qualities in him are equally responsible. He suffers both from diffuseness and from compression. Gebir is a thicket of grand poetical properties. Sonorous gusts of fitful, shadowy ideas blow about it. They constantly elude any ordinary mental grasp. The trilogy centring around ill-starred Queen Giovanna is a labyrinth of a hundred and forty pages, in which history 
and romance go astray, mimicking one another's voice. Sometimes, on the other hand, as in Coresus and Callirhoë, and in many of the lyrics, he is so precipitately brief that the climax is an affront. Then, in the longer pieces, based on history, he is apt after an evil and favourite habit of the British Legislature, to proceed 'by reference'. That is, he assumes that the real events are known, or will be looked up. Not less offensive to popular taste is the want of sifting. Mere exercises, like the trial of Aeschylus, the bandying of indifferent compliments between him and Sophocles, the slaughter of Corythos by his father, and the rescue of Alcestis by Hercules, elbow scenes of absolute loveliness, such as The Hamadryad, Iphigeneia, the first part of Corythos, Peleus and Thetis, and Polyxena. A similar want of assortment doubtless has helped to spoil even the garden of lyries for a public which will not be at the pains to distinguish between flowers and weeds.

The same public, docile when it is a question of economy of brain-worry, has been satisfied to take it on trust from the initiated that Landor is a poet who sits on the dais. It does not trouble to scrutinize his right. Were it to inquire, it would learn that he had the poet's gift of imparting to his verse, over and above all else, a feeling as if of a spirit having hovered near. The attribute is to be prized beyond all others, when apprehended; for it is the readers' then as much as the writer's ; and every writer rejoices to share the delight with them. Landor, it is to be feared, had little of that pleasure. But the popular coldness, which was his ordinary experience, cannot have deprived him of the rapture of feeling the descent of inspiration. I read a sense at least of this supreme joy in his own review of a career which impressed his contemporaries as harassed-however needlessly-cross-grained, 


\section{THE POETS}

ineffectual, and unhappy. With spiritual visitations such as favoured him, he cannot have wholly mocked himself in the farewell, which, while it charms, brings somehow an ache to admiring hearts :

I strove with none; for none was worth my strife.

. Nature I loved, and, next to Nature, Art;

I warm'd both hands before the fire of life;

It sinks, and I am ready to depart. ${ }^{17}$

The Works and Life of Walter Savage Landor. Eight vols. Chapman and Hall, 1876. Vol. vii, Gebir; Acts and Scenes; Hellenics. Vol. viii, Miscellaneous Poems.

1 The Hamadryad (Hellenics), vol. vii, p. 427.

2 Iphigeneia and Agamemnon (Hellenics), vol. vii, p. 488.

3 The Espousals of Polyxena (Hellenics), vol. vii, p. 512.

4 Beatrice Cenci (Dialogues in verse), vol. vii, p. 363.

5 Henry the Eighth and Anne Boleyn (Dialogues in Verse), vol. vii, p. 337.

- On Catullus (The Last Fruit off an Old Tree), vol. viii, p. 162.

7 Young (Last Fruit, \&c), vol. viii, p. 172.

${ }^{8}$ Collection of 1846 , No. 63, vol. viii, p. 21.

- Ibid., No. 58, vol. viii, pp. 19-20.

10 Ibid., No. 200 , vol. viii, p. 96.

11 Additional Poems, No. 96, vol. viii, p. 337.

12 Collection of 1846 , No. 152, vol. viii, p. 79 .

${ }_{13}$ Ibid., No. 102, vol. viii, p. 52.

14 Ibid., No. 213, vol. viii, p. 103.

15 Ibid., No. 93, vol. viii, p. 47.

${ }_{16}$ Ibid., No. 61, vol. viii, pp. 20-1.

17 Prefixed to volume: The Last Fruit off an Old Tree. E. Moxon, 1853. 


\section{THOMAS MOORE}

$1779-1852$

Courage is required to praise Moore even moderately. Admiration of him is likely to be taken as evidence of a want of intellectual vigour, and of a propensity to the heinous crime of cheap sensibility. Notwithstanding liability to these terrible charges, I will not without a struggle be parted from an old favourite. Now as formerly I find in Moore a power of affording to particular moods the satisfaction they have been craving. Not merely are there special poems which I could not consent to abandon; there even, I believe, is a spirit in the whole which, if dismissed to wander outside the recognized poetic domain, would leave a void not easily filled.

Much of Moore's literary energy, I willingly allow, was spent on work long since out of date. The smoothness of his Anacreon is not Hellenic enough to content modern scholarship. The vivacity of his political and social satire evaporated as it hit its mark. The Twopenny Post-Bag, The Intercepted Letters, and The Fudge Family in Paris, with a legion of political epigrams, are forgotten; and it is useless to complain. Their humour and wit, sometimes riotous, oftener caustic, always gay and audacious, require too much reading-in, between the lines, of scandals connected with Carlton House-no longer a Whig centre-and its unwieldy master. For very different reasons Lalla Rookh is similarly neglected. There also I equally recognize the uselessness of quarrelling with public taste. The diffuseness, especially in the Fire Worshippers, and a want 
of reasonableness, towards which Fadladeen really was over-tolerant, in the entire scheme of the tale of The Veiled Prophet, might have been excused. The treatment of the general theme as if it were a huge operatic libretto, a medley of musical spectacles, was fatal. Moore had learnt so perfectly the art of writing words to an air that he composed a poem of the dimensions of an epic on the same lines. The crowd of imagery in a work on that scale is bewildering. The covering plot is smothered in roses; it is drowned in a butt of sweet malmsey. The whole produces the effect not so much of poetry pure and simple, as of poetry in solution.

All that remains positively extant out of a prolonged and industrious career's achievement is an accumulation of lyrics. Naturally they differ widely in degrees of merit. A few deserve to survive by virtue of their saucy insolence; for example-juvenile exercise though it was-

When I lov'd you, I can't but allow

I had many an exquisite minute ;

But the scorn that $I$ feel for you now

Hath even more luxury in it.

Thus, whether we're on or we're off,

Some witchery seems to await you ;

To love you was pleasant enough,

And oh! 'tis delicious to hate you ! 1

The clashing melody will rescue one at least of the Sacred Songs :

Sound the loud timbrel o'er Egypt's dark sea!

Jehovah has triumphed-his people are free.

Sing-for the pride of the tyrant is broken,

His chariots, his horsemen, all splendid and brave-

How vain was their boast, for the Lord hath but spoken, And chariots and horsemen are sunk in the wave.

Sound the loud timbrel o'or Egypt's dark sea ;

Jehovah has triumphed-his people are free ; ${ }^{2}$ 
A Canadian boat-song is charmingly simple :

Faintly as tolls the evening chime

Our voices keep tune and our oars keep time.

Soon as the woods on shore look dim,

We'll sing at St. Anne's our parting hymn.

Row, brothers, row, the stream runs fast,

The Rapids are near, and the daylight's past.

Why should we yet our sail unfurl?

There is not a breath the blue wave to curl.

But, when the wind blows off the shore,

$\mathrm{Oh}$ ! sweetly we'll rest our weary oar.

Blow, breezes, blow, the stream runs fast,

The Rapids are near, and the daylight's past ; 3

and old associations cling about :

Oft in the stilly night,

Ere Slumber's chain has bound me,

Fond Memory brings the light

Of other days around me.4

But the Irish Melodies are the real sheet-anchor of Moore's fame. Modern critics have often assured them they are dead. Some have accepted the judgement against them of an exaggerated sentimentality, and rest in their graves. Others, a fair number, are obstinately incredulous, and insist upon going on breathing. I should be sorry for myself if $I$ ceased to find romance in :

The harp that once through Tara's halls

The soul of beauty shed,

Now hangs as mute on Tara's walls,

As if that soul were fled.-

So sleeps the pride of former days,

So glory's thrill is o'er,

And hearts that once beat high for praise,

Now feel that pulse no more. 
No more to chiefs and ladies bright

The harp of Tara swells ;

The chord alone, that breaks at night,

Its tale of ruin tells.

Thus Freedom now so seldom wakes,

The only throb she gives,

Is when some heart indignant breaks,

To show that still she lives ; ${ }^{5}$

tragic pathos in :

Oh ! breathe not his name, let it sleep in the shade, Where cold and unhonour'd his relics are laid : Sad, silent, and dark, be the tears that we shed, As the night-dew that falls on the grass o'er his head.

But the night-dew that falls, though in silence it weeps, Shall brighten with verdure the grave where he sleeps; And the tear that we shed, though in secret it rolls, Shall long keep his memory green in our souls ; ${ }^{6}$

All exhale a gallant assurance that time has no power, unless we abet it, to grind our souls to dust between its remorseless mill stones; that, if we choose, we can go on sunning ourselves in the smiles of the young and fair; that there is no such thing as decrepit, care-worn age :

It is not while beauty and youth are thine own, And thy cheek unprofan'd by a tear,

That the fervour and faith of a soul can be known, To which time will but make thee more dear; No, the heart that has truly lov'd never forgets, But as truly loves on to the close, As the sun-flower turns on her god when he sets, The same look which she turn'd when he rose ; ${ }^{7}$

that joy is immortal for the faithful and brave :

Let Fate do her worst, there are relics of joy, Bright dreams of the past, which she cannot destroy ; 
Which come in the night-time of sorrow and care, And bring back the features that joy used to wear. Long, long be my heart with such memories fill'd ! Like the vase in which roses have once been distill'dYou may break, you may shatter the vase, if you will, But the scent of the roses will hang round it still $;^{8}$

that it was the Irishman's duty to pray for the prosperity of his country, and exult should it come, but that his love was hers now because she needed it:

Remember thee? Yes, while there 's life in this heart, It shall never forget thee, all lorn as thou art;

More dear in thy sorrow, thy gloom, and thy showers, Than the rest of the world in their sunniest hours.

Wert thou all that I wish thee, great, glorious, and free, First flower of the earth, and first gem of the sea, I might hail thee with prouder, with happier brow, But oh ! could I love thee more deeply than now ??

If I do not quote from the Last Rose of Summer, it is not because it is hackneyed. It is that I suppose there is no English song which dwells more habitually on the lips of memory.

I think it ought to be possible to form a fair opinion of Moore's place in the poetical hierarchy from materials at everybody's command. There should be no difficulty at any rate in admitting his title to entrance within the circle of poets. In the century preceding his birth, isolated English songs here and there may be found to be set against his. Though Scotland twenty years earlier had produced Burns, the rest of the United Kingdom can show no body of lyrics to match them since Herrick's. He had a right to do more than boast that, as his own island's minstrel, he was the first of his line: 
Dear Harp of my Country ! in darkness I found thee, The cold chain of silence had hung o'er thee long, When, proudly, my own Island Harp, I unbound thee, And gave all thy chords to light, freedom, and song ! 10

South of the Tweed he could claim the same precedence. His, as singing poetry-drawing-room singing, perhapsoccupies a place by itself. Opinions may differ on the exact rank of the whole department in literature. At all events, he would be a bold critic who should attempt to warn the class off the slopes of Parnassus. In no case could he make out good warrant for beginning the ostracism with Moore.

From another point of view he can assert an exceptional claim to regard. The meeting of poetry and music in his verse, natural as it may seem, is phenomenal. The two are sister arts which by no means necessarily agree. Often, especially of late, they have been in deadly antagonism. It is impossible not to rejoice when their union is spontaneous, as in the Muse of Moore. He has himself declared that he considered his songs ' a sort of compound creations, in which the music formed no less essential a part than the verses'. He lamented that he had to print editions in which they were separated from the airs.11 Lyrics without a musical setting appeared to him to be a contradiction in terms. As we read his, we may almost hear him warbling them as they flow. Music perpetually has been, and is being, made a cover for execrable verse. No one with justice can say this of the Melodies. They always are sweet, if occasionally to excess, and with a feeling genuine so far as it goes. Had indeed his raptures been wholly artificial, or his indignation ever false, an intelligence keen as his, and a spirit as upright, would have banned them long before his censors detected the shortcomings. A 
generous and kindly heart constantly is playing, and as evidently a sagacious brain is conducting the orchestra. Both poet and musician are picturesque, able, romantic, and tender; and the man himself never fails to interest.

In the face of divers fine poetic qualities engaged in unison, it is disappointing for me as a juror-not a judgeto have to return an adverse general verdict in the Court of poetic art. Gladly I qualify it by extenuating circumstances-I admire the man; I love many of the poems ; I condemn the poet. The decision is painful, but unavoid. able. A poet must be pronounced a failure when he has no power of sowing in his readers the germs of future thoughts or impulses. How long did ever emotion last which was stirred by the pitifulness of Paradise and the Peri, or the sadness of The Minstrel Boy? The fault is radical, I fear. Results are proportionate to their causes ; and song, to live and be fruitful, must have been born in travail. Nature was unkindly kind to Moore in endowing him with an ear too instinctively true, too miscellaneous a sympathy, and a wit too docile and dexterous. His gifts seduced him into disregarding his own axiom that 'labour to the writer' is a condition of ' any great pleasure to the reader' ${ }^{12}$ Otherwise, it is inconceivable that most of the produce of an imagination fertile like his, after having been worshipped by contemporaries, should be lost and forgotten, except for its casual and half contemptuous preservation in antiquated piano scores.

The Poetical Works of Thomas Moore. Collected by Himself. Ten vols. Longmans, 1853.

1 To - (Juvenile Poems), vol. i, p. 288.

2 Miriam's Song (Sacred Songs), vol. iv, p. 269.

A Canadian Boat Song. Written on the River St. Lawrence (Poems relating to America), vol. ii, pp. 322-4.

vOL. II 


\section{THE POETS}

- Scotch Air (National Airs), vol. iv, p. 167.

5 The Harp (Irish Melodies), vol. iii, p. 229.

- Oh! Breathe Not - (ibid.), vol. iii, p. 227.

? Believe me - (ibid.), vol. iii, p. 259.

8 Farewell ! (ibid.), vol. iii, p. 325.

9 Remember Thee ? (ibid.), vol. iv, p. 11.

${ }^{0}$ Dear Harp - (ibid.), vol. iii, p. 354.

11 Preface-Poetical Works, vol. v, pp. xix-xx.

12 A Melologue upon National Music-Advertisement, vol. $\nabla$, p. 119. 


\section{JAMES HENRY LEIGH HUN'T}

\section{$1784-1859$}

A LIVING Statesman, in dedicating a memorial to Leigh Hunt, confessed to having read none of his writings. The same admission, as to all but one short poem, might be made by a majority of educated Englishmen. I do not know whether the fact reflect more discredit on those who neglect a charming writer, or more honour on the national genius for having produced authors of such merit, and in such plenty, as to have rendered him superfluous. Certainly any one who takes up a volume by Leigh Hunt for the first time will be surprised at its rare distinction of style. He ought to be equally hurt, if not by regret for a pleasure he has hitherto denied himself, by some sense at any rate of ingratitude to the kindly spirit which devoted itself during long years to the endeavour to entertain a careless public.

Grace is a special quality. It is not the highest. Beings of a lofty nature may be destitute of it. An addition of an excellence will sometimes mar it, or obscure the impression of its presence. Though very far from being a definition of genuine poetry, the Nothing-too-much commonly is part of one. Without claiming for Leigh Hunt that he never offends against the canon, I believe his instinct for it to be generally true. Whatever else his poetry is not, almost invariably it is in perfect taste. I never begin The Story of Rimini without a prejudice against its existence. When Dante had done it all in six dozen inimitable lines, it is sacrilege to pretend to 
interpret and develop. Leigh Hunt's own exquisite rendering of the original ${ }^{1}$ is itself a sufficient rebuke of his attempt at explaining. Yet $I$ always end by acknowledging to myself that, if it were to be done, the decline or rise from innocent boy-and-girl friendship to passionate love could not have been more delicately shadowed.

The same praise can be bestowed, and without fear here of Dante's awful frown, on the rejuvenescence conferred upon the tragedy of Hero and Leander, an old tale,

\section{and yet as young}

And warm with life as ever minstrel sung;

a chronicle as

of two that died last.night,

So might they now have liv'd, and so have died ;

The story's heart, to me, still beats against its side. ${ }^{2}$

Grace, again, carries away any suggestion of coarseness in The Gentle Armour, if it cannot, any more than in a better known later poem on the same subject, veil the mediaeval brutalism of the Godiva myth itself. It resists, as with few even much greater poets it could, the temptation to let a noble idea, like that of Abou Ben Adhem, overgrow itself. Thanks to its sympathetic guidance, roses and lilies in Leigh Hunt's nineteenth-century garden might have been gathered by Ariel in his roamings from Prospero's Atlantis. ${ }^{3}$

The kindly instinct does not desert his pen even when the satirist and victim of the elderly royal Adonis turns volunteer Laureate, and sings the prettiest of lullabies over the cradle of a Queen's babe :

Welcome, bud beside the rose,

On whose stem our safety grows;

Welcome, little Saxon Guelph ;

Welcome, for thine own small self; 
Nought of all the news we sing

Dost thou know, sweet ignorant thing ;

Nought of planet's love, nor people's ;

Nor dost hear the giddy steeples

Carolling of thee and thine,

As if heav'n had rain'd them wine,

E'en thy father's loving hand,

Nowise dost thou understand,

When he makes thee feebly grasp

His fingers with a tiny clasp;

Nor dost know thy very mother's

Balmy bosom from another's,

Nor the eyes that, while they fold thee,

Never can enough behold thee.

Mother true and good has she,

Little strong one, been to thee.

She has done her strenuous duty

To thy brain and to thy beauty,

Till thou cam'st a blossom bright,

Worth the kiss of air and light. ${ }^{4}$

He has deeper strains at his command. Lines simple enough, the doom of universal humanity, he has combined into a grisly portrait of the King of Terrors. No common minor poet's brain could have conceived and drawn it. A grand touch in Mahmoud is the Sultan's acceptance of grief as a subject's indefeasible title to an instant audience

'Sorrow,' said Mahmoud, ' is a reverend thing ;

I recognize its right, as King with King.' 5

Brilliant rays pierce through the somewhat bewildering haze of the controversy between Captain Sword and Captain Pen :

O God ! let me breathe, and look up at the sky!

Good is as hundreds, evil as one ;

Round about goeth the golden sun. ${ }^{6}$

As for Abou Ben Adhem, it is admitted to be a diamond : 
Abou Ben Adhem-may his tribe increaseAwoke one night from a deep dream of peace, And saw within the moonlight in his room, Making it rich, and like a lily in bloom, An angel writing in a book of gold :Exceeding peace had made Ben Adhem bold, And to the presence in the room he said, - What writest thou ?'-The vision raised its head, And with a look made of all sweet accord, Answer'd, 'The names of those who love the Lord.' - And is mine one ?' said Abou, 'Nay, not so,' Replied the angel. Abou spoke more low, But clearly still ; and said, 'I pray thee then, Write me as one that loves his fellow-men.'

The angel wrote, and vanish'd. The next night

It came again with a great wakening light, And show'd the names whom love of God had bless'd, And lo ! Ben Adhem's name led all the rest.?

An Angel in the House comes not far behind :

How sweet it were, if without feeble fright, Or dying of the dreadful beauteous sight, An angel came to us, and we could bear To see him issue from the silent air At evening in our room, and bend on ours His divine eyes, and bring us from his bowers News of dear friends, and children who have never Been dead indeed-as we shall know for ever. Alas ! we think not what we daily see About our hearths,-angels that are to be, Or may be, if they will, and we prepare Their souls and ours to meet in happy air,A child, a friend, a wife whose soft heart sings In unison with ours, breeding its future wings. ${ }^{8}$

He hymns the Grasshopper and the Cricket in lines which might be a version of a Greek epigram if they were not an original English sonnet : 
Green little vaulter in the sunny grass, Catching your heart up at the feel of June, Sole voice that 's heard amidst the lazy noon, When even the bees lag at the summoning brass ; And you, warm little housekeeper, who class With those who think the candles come too soon, Loving the fire, and with your tricksome tune Nick the glad silent moments as they pass.

Oh sweet and tiny cousins, that belong, One to the fields, the other to the hearth, Both have your sunshine; both, though small, are strong At your clear hearts; and both seem given to earth To ring in thoughtful ears this natural songIndoors and out, summer and winter, Mirth. ${ }^{9}$

When he pleases he is as saucy as Villon, without it ever pleasing him to raise a blush. But whatever the other attractions of his Muse, grace remains the peculiar and distinguishing property.

In his career, and for his posthumous fame, it was and is a double-edged endowment. I suppose that it was connected in him with an exceptional capacity for absorbing his thoughts and feelings, his entire personal being, into another's. Leigh Hunt's nature was able to identify itself without the least violence with whatever was artistically dainty, and emotionally beautiful. Hence his elegance as a writer, and probably also his weakness both as writer and as man. No writer was ever less self-centred. He was fashioned to flutter about flowers of fancy and art; sucking, rarely in the depths, their honey; successful in discovering, not in storing it. It is not strange that in his early days hard measure should have been dealt out to such a nature. At his dawn partisanship flayed him with the bitter tongue of Christopher North, as well as providing him, more materially, with a lodging in Coldbath Fields 
Prison. Even at his sunset his own familiar friend, unintentionally, we may be sure, was the cause of the fastening upon him of an odious character in fiction. A delightful writer both in prose and verse, he never was visited by a gleam of prosperity. The public cared little for one who had no message of his own to deliver, not even an agreeable rancour to wreak. Had he, like the proverbial worm, been given to turning, he might at least have excited interest, if not compassion. As it was, he simply went on with his singing, not admiringly remarked in life, and scarcely at all since.

He was and is, I dare say, one of the poets the world can do without, though I think it a pity it should. In any case it may be hoped and believed that to him, singing as a bird sings, because it must, so pleasure came from his song, as it comes to a bird, because to the singer of a sweet song pleasure must.

The Poetical Works of Leigh Hunt. E. Moxon, 1844. (Stories in Verse: by Leigh Hunt. G. Routledge \& Co., 1855.)

1 Paolo and Francesca (Stories in Verse), pp. 300-303.

${ }^{2}$ Hero and Leander, Canto i (ibid.), pp. 129 and 130.

${ }^{3}$ Songs and Chorus of the Flowers (Moxon's ed.), pp. 167-8.

4 To the Infant Princess Royal (ibid.), pp. 159-61.

5 Mahmoud (ibid.), p. 71.

- Captain Sword and Captain Pen (ibid.), p. 96.

? About Ben Adhem and the Angel (ibid.), p. 74 .

8 An Angel in the House (ibid.), p. 166.

- The Grasshopper and the Cricket (ibid.), p. 174. 


\section{GEORGE GORDON, LORD BYRON}

\section{$1788-1824$}

What of this torrent of verse, myrrh and gall, poured forth in some fifteen years-is it a living stream, or unfiltered surface-water? Is it the cursing epitaph on rotting Timon's tomb by the wild sea-waves, or his imprecation on his age and fellow men, mingled with a shower of gold, as the misanthrope stands, a prophet of evil, at the mouth of his forlorn cave?

If a voice from the grave, it is at any rate a mighty voice, as of a Titan buried alive under Etna. Such modern criticism as is prone to deny present active existence to Byron, will not dispute that he lived once, and issued royal proclamations. He stood for force, movement, perturbation. Wordsworth, Coleridge, Shelley, and Keats were more radical revolutionists in poetry. Byron never ceased to profess himself a disciple of Dryden and Pope. But the most fervent admirers of the first four would not pretend to compare the contemporary innovating influence of the whole of them in literature with Byron's. He did as much towards extending the sway of England as the victories of Nelson and Wellington, or the despotic will of Pitt. The personality, in its weaknesses as in its strength, fascinated. His pilgrimage of passion and remorse marked its course as with red-hot lava on the heart of Europe.

Now, when the rush of molten matter has cooled and stiffened, it is easy to analyse its aberrations and impurities. Its extravagances are monstrous. Whatever the crimes of 
Castlereagh against freedom, the cause of liberty is injured by sneers at the 'tinkering slave-maker', by insults to his corpse :

He has cut his throat at last! He! Who ?

The man who cut his country's long ago.

The Poet-Laureate is

shuffling Southey, that incarnate lie ;

and Wordsworth's principal work :

A drowzy frowzy poem, call'd the 'Excursion', Writ in a manner which is my aversion.

The egotism passes all bounds. The quality is a foible dear to the poetic temperament-to the highest, and the lowestto any but Shakespeare's as a dramatist-and he takes his revenge in the Sonnets. The temptation to indulgence in it is so irresistible, that, according to a subtle poet-critic in the early nineteenth century, sensitive bards, conscious, and ashamed, of its power over them, have chosen themes alien to their taste to be able, under cover of them, to stray, as if by accident, into scenes enshrining themselves. That was not Byron's way. He makes no disguise of his intention never to be off the stage. The result is that his favourite moods, cynicism in Don Juan, satiety in Childe Harold, have an air of cheapness. Sceptical readers experience a general impression of insincerity. They suspect a want of spontaneity everywhere, in the pathos, as in the disgust. The texture they see often is threadbare, as it could not but be, with a heart dried up by sensual licence, and obliged to trust to the brain to do the creative work of both.

He rebelled against law and order because he had not set them in motion; not, as his companion Shelley, from 
a generous rage against a narrow-minded depotism. Nobody now believes in the genuineness of his indignation against tyranny. A Lord, with the manners of the Prince Regent, preaching Socialism is a ridiculous figure to the present generation. The admiration he gained for his errors has itself ruined his posthumous renown. He is punished by the taunts of the new age, for having hypnotized its predecessor into adoring his follies. With all the mimicry, all the flattery, all the absurdity, it is the more wonderful that a real poet, a seer of visions, should remain recognizable beneath. We may pass by much that he wrote. A majority of the occasional pieces would probably have been smothered by himself had he foreseen the celebrity of Childe Harold and Don Juan. Satire, though vigorous and scathing as in English Bards and Scotch Reviewers, The Vision of Judgement, and The Curse of Minerva, naturally is short-lived. The Plays are too poetical for dramas, too dramatic for poems. As the eye glances over the titles of many of the published works, scarcely even an emotion of curiosity stirs.

Others there are on which we pause for a moment, and with delight, whenever accident recalls them. We cannot help recognizing power, for instance, in The Destruction of Sennacherib :

Like the leaves of the forest when Summer is green,

That host with their banners at sunset were seen;

Like the leaves of the forest when Autumn hath blown,

That host on the morrow lay wither'd and strown ; ${ }^{1}$

and in the contrast, in the Ode to Napoleon, between his submissive abdication and Sulla's :

The Roman, when his burning heart

Was slaked with blood of Rome,

Threw down the dagger-dared depart,

In savage grandeur, home- 


\section{THE POETS}

He dared depart in utter scorn

Of men that such a yoke had borne,

Yet left him such a doom !

His only glory was that hour

Of self-upheld abandon'd power. ${ }^{2}$

A mist of blood and tears mitigates the hectic hues of The Dream. ${ }^{3}$ There is music for us still in :

She walks in beauty, like the night

Of cloudless climes and starry skies ;

And all that 's best of dark and bright

Meet in her aspect and her eyes ; ${ }^{4}$

and :

Oh could I feel as I have felt,--or be what I have been,

Or weep as I could once have wept o'er many a vanish'd scene ; As springs in deserts found seem sweet, all brackish though they be, So, midst the wither'd waste of life, those tears would flow to me."

We admire : we do not spontaneously reopen the volume.

It is the same with compositions of ancient renown, like The Giaour, The Bride of Abydos, The Corsair, Lara, The Prisoner of Chillon, Parisina, The Siege of Corinth. Echoes rise, and insist on rising, from them. The glowing west continually reminds how,

Slow sinks more lovely ere his race be run, Along Morea's hills the setting sun ; Not, as in Northern climes, obscurely bright, But one unclouded blaze of living light.

On old Aegina's rock and Idra's isle, The god of gladness sheds his parting smile ; O'er his own regions lingering, loves to shine, Though there his altars are no more divine. Descending fast the mountain shadows kiss Thy glorious gulf, unconquer'd Salamis ! Their azure arches through the long expanse More deeply purpled meet his mellowing glance, 
And tenderest tints, along their summits driven, Mark his gay course, and own the hues of heaven ; Till, darkly shaded from the land and deep, Behind his Delphian cliff he sinks to sleep. ${ }^{6}$

A new age has forgotten, not merely the Giaour, but the Philhellenic fire its author played a foremost part in kindling ; it cannot have forgotten :

He who hath bent him o'er the dead

Ere the first day of death is fled,

The first dark day of nothingness,

The last of danger and distress-

Before Decay's effacing fingers

Have swept the lines where beauty lingers-

And mark'd the mild angelic air,

The rapture of repose that's there,

'The fix'd yet tender traits that streak

The languor of the placid cheek,

And-but for that sad shrouded eye

That fires not, wins not, weeps not, now,

And but for that chill, changeless brow,

Where cold Obstruction's apathy

Appals the gazing mourner's heart,

As if to him it could impart

The doom he dreads, yet dwells upon ;

Yes, but for these and these alone,

Some moments, ay, one treacherous hour,

He still might doubt the tyrant's power ;

So fair, so calm, so softly seal'd,

The first, last look by death reveal'd !

Such is the aspect of this shore;

'Tis Greece, but living Greece no more !

So coldly sweet, so deadly fair,

We start, for soul is wanting there.?

Though few read the once fascinating Tale it introduces, fower forget the prelude to one of its cantos:

'The winds are high on Helle's wave,

As on that night of stormy water, 
When Love, who sent, forgot to save The young, the beautiful, the brave,

The lonely hope of Sestos' daughter. $\mathrm{Oh}$ ! when alone along the sky

Her turret torch was blazing high, Though rising gale and breaking foam, And shrieking sea-birds warn'd him home; And clouds aloft and tides below, With signs and sounds forbade to go, He could not see, he would not hear, Or sound or sign foreboding fear ; His eye but saw that light of love, The only star it hail'd above ; His ear but rang with Hero's song, 'Ye waves, divide not lovers long.' 8

How beautiful such things are, and how sad to know, as well as impossible to deny, that the courts of the fairy palaces of fancy whence the romantic strains issued are now grassgrown, like the streets of lordly Ferrara. Sic transit gloria-but not always;-whatever the elevation or caprices of taste, I will never believe that the world can neglect Childe Harold, or passages in Don Juan which are not mere screams of despairing mockery.

Nearly a century has run out since Europe, astonished and spell-bound, tracked as strange a pilgrim as even Peter the Hermit ever enlisted in his devious wanderings over Europe. It hung upon the wanderer's every note, whether he sang a bull fight, or of murderous war-when

Death rides upon the sulphury Siroc,

Red Battle stamps his foot, and nations feel the shock-9

to its climax in the death struggle at Waterloo, with the final fall there of an Empire all but universal, and its Earth-God. It thrilled to his appeal to Greeks, and for Greece; above all, to his revelation of the magic of Italy; and a wider world thrills as before. 
Not a traveller crosses the Rialto without the melody at his heart :

In Venice 'Tasso's echoes are no more, And silent rows the songless gondolier; Her palaces are crumbling to the shore, And music meets not always now the ear ; Those days are gone-but Beauty still is here. States fall, arts fade-but Nature doth not die, Nor yet forget how Venice once was dear, The pleasant place of all festivity, The revel of the earth, the masque of Italy : ${ }^{10}$

No stranger paces the Tuscan Westminster Abbey without recalling a reproach, as well as a panegyric :

Ungrateful Florence : Dante sleeps afar, Like Scipio, buricd by the upbraiding shore; Thy factions, in their worse than civil war, Proscribed the bard whose name for evermore Their children's children would in vain adore With the remorse of ages; and the crown Which Petrarch's laureate brow supremely wore,

Upon a far and foreign soil had grown, His life, his fame, his grave, though rifled-not thine own.

And Santa Croce wants their mighty dust;

Yet for this want more noted, as of yore

The Caesar's pageant shorn of Brutus' bust,

Did but of Rome's best Son remind her more. ${ }^{11}$

Beside yellow Tiber, flowing through a marble wilderness, lone mother of dead empires, the Niobe of nations; though no longer, as for Byron,

Childless and crownless in her voiceless woe, ${ }^{12}$

his voice remains audible and eloquent. The sanctuary and home

Of art and piety-Pantheon! pride of Rome, ${ }^{13}$

is his monument as much as Raffaelle's and Victor Em. manuel's. I have never visited the Forum, transformed 
as it now is from its aspect to him, without viewing it first through his eyes, with its then single manifest break to the all-concealing level :

Tully was not so eloquent as thou,

Thou nameless column with the buried base !

What are the laurels of the Caesar's brow ?

Crown me with ivy from his dwelling-place. ${ }^{14}$

In simple fealty still to Childe Harold, on my first juvenile visit, I, like many another tourist, began by hunting out, not without difficulty, the apocryphal, and now discarded statue of Pompey :

And thou, dread statue! yet existent in

The austerest form of naked majesty,

Thou who beheldest, 'mid the assassins' din,

At thy bathed base the bloody Caesar lie,

Folding his robe in dying dignity,

An offering to thine altar from the queen

Of gods and men, great Nemesis! Did he die,

And thou, too, perish, Pompey? have ye been

Victors of countless kings, or puppets of a scene ? ${ }^{15}$

Archaeology may ridicule enthusiasm over the wrong relics. It will never lay bare on the Appian Way aught to interest as, at its entrance :

a stern round tower of other days,

Fair as a fortress, with its fence of stone, Such as an army's baffled strength delays, Standing with half its battlements alone, And with two thousand years of ivy grown The garland of eternity, where wave

The green leaves over all by time o'erthrown ;-

What was this tower of strength ? Within its cave

What treasure lay so lock'd, so hid ?-A woman's grave. ${ }^{16}$

It is entrancement-romance, history, miracles of art and nature, letters, hate and love-the whole an ever. changing, ever-lovely diorama, contrived as a framework 
for man's, one man's, emotions and ambitions! In this glorious guide-book, whether it lead us amidst tempests, in which

every mountain now hath found a tongue,

And Jura answers, through her misty shroud,

Back to the joyous Alps, who call to her aloud! 17

along streams dyed by day and night contending,

The odorous purple of a new-born rose ; ${ }^{18}$

through wrecks of realms strewing dread and lonely ocean's shores; past peaks of Alps throning

\section{Eternity in icy halls \\ Of cold sublimity ; ${ }^{19}$}

by arrowy, storied rivers, beside battlefields infamous for martial 'cut-throats', or famed for stainless victories, like Morat and Morgarten; by homes of

The self-torturing sophist, wild Rousseau ; ${ }^{20}$

of Voltaire, the lord of irony,

and of

Sapping a solemn creed with solemn sneer ; ${ }^{21}$

The starry Galileo, witn his woes ; ${ }^{22}$

or tombs, as of Laura's lover in rustic Arqua-

Where'er we tread 'tis haunted, holy ground !

Again, Don Juan! Faded, tawdry, often, as De Quincey justly calls allusions to Southey's and Coleridge's marriages, ignoble? Alas! yes. And the cruel waste! Righteous anger, grief, generosity, magnanimity, thought, shot out upon a dustheap! Whatever was paltry, absurd, unbecoming, contemptible in contemptuousness, in Childe Harold, is here expanded and exaggerated. The whole is flavoured to nausea with the topsy-turvy theory of morals - the redeemability of malpractices by remorse, or by the insult of pity, while the fruit of iniquity and cruelty is

VOL. II 
actually between the teeth. Cynicism is made welcome to float away on a flood of self-satisfied tears. Guilt seems to expect to be fondled like a lost sheep, however many times it may have chosen to repeat its wanderings in the wilderness.

I scarcely know whether it be an extenuation, or an aggravation, that Don Juan has another side. Suddenly it breaks into episodes of rare grandeur. The description of the shipwreck has seldom, if ever, been equalled:

Then rose from sea to sky the wild farewell-

Then shriek'd the timid, and stood still the braveThen some leap'd overboard with dreadful yell, As eager to anticipate their grave ;

And the sea yawn'd around her like a hell,

And down she suck'd with her the whirling wave,

Like one who grapples with his enemy,

And strives to strangle him before he die.

And first one universal shriek there rush'd,

Louder than the loud ocean, like a crash

Of echoing thunder; and then all was hush'd,

Save the wild wind and the remorseless dash

Of billows; but at intervals there gush'd,

Accompanied with a convulsive splash,

A solitary shriek, the bubbling cry

Of some strong swimmer in his agony. ${ }^{23}$

Five-and-twenty stanzas suffice for the maritime disaster. Suwarrow and his Russians need five times the number to make

an end of Ismail-hapless town !

Fair flash'd her burning towers o'er Danube's stream, And redly ran his blushing waters down. The horrid war-whoop and the shriller scream

Rose still ; but fainter were the thunders grown; Of forty thousand who had mann'd the wall, Some hundreds breath'd-the rest were silent all ! ${ }^{24}$ 
Each scene is enough to have founded a reputation; and, with all their transcendent grandeur, the two do not stand alone. All the sixteen Cantos are studded with wit, and even wisdom. Often it is hard to say whether it be one or the other, or both. What of the bitter after-taste of vice?

There is no sterner moralist than Pleasure ! 25

What of the suicide's motive?

Less from disgust of life than dread of death. ${ }^{26}$

What of the great line, at once anthem to genius, and dirge over a nation?

Cervantes smiled Spain's chivalry away. ${ }^{27}$

What, finally, of-

Great Socrates-And thou, Diviner still,

Whose lot it is by man to be mistaken,

And thy pure creed made sanction of all ill ?

Redeeming worlds to be by bigots shaken,

How was thy toil rewarded ? ${ }^{28}$

Then, too, it harbours the noble lyric :

The Isles of Greece, the Isles of Greece !

Where burning Sappho loved and sung,

Where grew the arts of war and peace,

Where Delos rose, and Phoebus sprung!

Eternal summer gilds them yet,

But all, except their sun, is set.

The mountains look on Marathon-

And Marathon looks on the sea ;

And musing there an hour alone,

I dream'd that Greece might still be free ;

For standing on the Persians' grave,

I could not deem myself a slave ! 29

And the-gleams of tenderness! Poetry offers few more 


\section{THE POETS}

delightful portraits among its myriad of girlhood than that of the daughter of

the mildest manner'd man

That ever scuttled ship, or cut a throat-

innocently guilty Haidée :

Round her she made an atmosphere of life.

The very air seem'd lighter from her eyes,

They were so soft and beautiful, and rife

With all we can imagine of the skies, And pure as Psyche ere she grew a wife-

Too pure even for the purest human ties;

Her overpowering presence made you feel

It would not be idolatry to kneel..$^{30}$

The chant of the Ave Maria! sighs about the figures of the boy and girl lovers, as if to condone the irregularity in their wooing, while

Not a breath crept through the rosy air,

And yet the forest-leaves seem'd stirred with prayer. ${ }^{31}$

Pathos is a scarce quality in Don Juan. It is to be prized accordingly where it is perceptible, as in the invocation of the Evening Star :

Whate'er our household gods protect of dear,

Are gather'd round us by thy look of rest ;

Thou bring'st the child, too, to the mother's breast; 32

and again in a classical allusion :

When Nero perish'd by the justest doom,

Amidst the roar of liberated Rome,

Some hands unseen strew'd flowers upon his tomb. ${ }^{33}$

Is it pathos, or merely an epigram ?

And if $I$ laugh at any mortal thing,

'Tis that I may not weep ! 34

In the present day it is easy to decry Byron's reflections, 
his sentiment, as superficial and second-hand. Were they of the present date they might be. When he wrote he was a discoverer, a leader, a teacher. The fire which he kindled had inflamed himself first. His character, or what he chose should be accepted as it, may be read in every verse he printed. Every tale of his, every scene, every thought, breathes, and has life-breath of his life-in it. There is a splendour, a gaiety. His egotism may be ridiculous; he is not. With all the perversity, vanity, pretence, a feeling even of open air, of frank directness, mingles. Shades of a mighty company of real mourners, who attended yearly, daily,

The pageant of his bleeding heart,

still brood over his memory. Human nature loves to recognize a master; and it recognized him. Still, after three quarters of a century, he continues to reign, if within narrowed frontiers, a king by right divine.

The Poetical Works of Lord Byron (Oxford Edition). Henry Frowde : London, 1904.

${ }^{1}$ The Destruction of Sennacherib (Hebrew Melodies), p. 82.

2 Ode to Napoleon Buonaparte (Occasional Pieces), p. 73.

3 The Dream, July, 1816 (ibid.), pp. 90-2.

- She Walks in Beauty (Hebrew Melodies), p. 76.

${ }^{5}$ Stanzas for Music, March, 1815 (Occasional Pieces), p. 83.

- The Corsair, Canto iii, st. 1, pp. 284-5.

$?$ The Giaour, p. 246.

- The Bride of Abydos, Canto ii, st. 1, p. 263.

- Childe Harold's Pilgrimage, Canto i, st. 38, p. 182.

10 Ibid., Canto iv, st. 3, p. 221.

11 Ibid., Canto iv, stanzas 57 and 59, pp. 227-8.

${ }_{12}$ Ibid., Canto iv, st. 79, p. 230.

${ }^{13}$ Ibid., Canto iv, st. 146, p. 239.

14 Ibid., Canto iv, st. 110, p. 234.

${ }_{15}$ Ibid., Canto iv, st. 87, p. 231.

${ }^{16}$ Ibid., Canto iv, st. 99, p. 233. 


\section{THE POETS}

${ }^{17}$ Childe Harold's Pilgrimage, Canto iii, st. 92, p. 216.

${ }^{18}$ Ibid., Canto iv, st. 28, p. 224.

19 Ibid., Canto iii, st. 72, p. 212.

20 Ibid., Canto iii, st. 77, p. 213.

21 Ibid., Canto iii, st. 107, p. 218.

22 Ibid., Canto iv, st. 54, p. 227.

${ }^{23}$ Don Juan, Canto ii, stanzas 52-3, p. 656.

24 Ibid., Canto viii, st. 127, p. 753.

25 Ibid., Canto iii, st. 65, p. 680.

${ }_{26}$ Ibid., Canto xiv, st. 4, p. 805.

27 Ibid., Canto xiii, st. 11, p. 794.

${ }^{28}$ Ibid., Canto xv, st. 18, p. 818.

${ }^{29}$ Ibid., Canto iii, st. 86, p. 683.

${ }^{30}$ Ibid., Canto iii, st. 74, p. 681.

31 Ibid., Canto iii, st. 102, p. 685.

32 Ibid., Canto iii, st. 107, p. 686.

s3 Ibid., Canto iii, st. 109, p. 686.

34 Ibid., Canto iv, st. 4, p. 687. 


\section{PERCY BYSSHE SHELLEY}

\section{$1792-1822$}

The first and foremost impression of Shelley is of a spirit of unrest, brooding-no, hovering, swooping-over a return of Chaos, which it has engineered. We are conscious of a continual search by him for new elements whence to construct new Heavens and a new earth. It is the French Revolution, exhausted, crushed by main force for the moment below the surface, panting, protesting, fermenting, in a haughty English, aristocratic nature. Visibly and audibly it is rebellious and scornful. It has idealized passion, erecting it into a divine law. Hither and thither it rushes, raising an altar wherever fancy has alighted for the instant. Never without an idol it tramples on whatever is no longer for it adorable. All must acknowledge the fascination of each fresh conception, if only it were permitted to stay long enough for a day-dream to repose in it. There is a longing to inform with a body each exhalation as it rises; to condense the rainbow-hued vapour. Alas! the pageant of fairy castles which dissolve into air as we wind the horn at their gates at length disappoints and tires. We begin to doubt whether they be more than gossamers of an intellect uncertain of itself.

Shelley was a born poet, whom nature in a freak bent, and warped, perhaps, also enriched, by the circumstances of his time, parentage, and domicile. Being what thus he was, he could not have been other than a poet professed, and nothing else. He was endowed with faculties in 
abundance besides poetic imagination. His prose is delightful. He might have won fame as a novelist, a metaphysician, a religious teacher, a politician. As it was, from boyhood he chose, or, as doubtless he thought, was forced into, a social isolation which denied to his great intelligence any other fixed form of expression than poetry. Made for friendship, to admire, and be admired, to be a disciple, and have disciples, he did not take excommunication kindly. He threw the blame upon existing institutions, a feudal aristocracy, religion degenerated into formalism and priestcraft, statesmen, Courts, and Kings, Heaven itself. Refused an audience otherwise, he uttered his rage and contempt in verse. The narrow circle he joined in default of a larger gave him the public he needed. It was too affectionate, too deeply interested, to criticize as it might and could. He himself had too much to say, and felt too ardently, to care to stop and meditate. Often his rank exuberance is owing to the chase of a fugitive fancy. Forth has started one till a second got up, and set his brain coursing in a fresh direction.

His besetting fault as a poet is excess. Denunciation is pursued to scurrility. Descriptions of natural loveliness are lengthened into tedious langour. Vital problems are discussed, at once with too much subtlety, and too little depth. Redundancy damps the fire of Alastor, The Revolt of Islam, Rosalind and Helen, Epipsychidion, The Witch of Atlas, The Masque of Anarchy, Julian and Maddalo. It draws a film over The Sensitive Plant, and even the beauty of Adonais. Indignation raves in the greenness of Queen Mab, with its ' uncultured Hebrews' exulting in 'old Salem's shameful glories', and 'howling hideous praises to their Demon-God'! It blunts the edge of the more mature satires, Swellfoot the Tyrant, Castlereagh, 
and the rest. When, as frequently, the resentment is righteous in its origin, its virtue still, as with Byron's, is marred by vituperation. The fury of the flame turns the water into steam. However much there is to say, however suggestive the text to be expounded, the inability to know when to stop stifles the effect.

The blemishes are not surprising in the circumstances. There were his self-banishment from home and family, social ostracism, exalted views of duty to Humanity, not invariably carried into practice, a fervent belief in the existence of a conspiracy of Tories and critics to suppress him, and a combination of intellectual and spiritual, perhaps even social, pride with physical and moral shyness. Add the gifts, in such a medley insidiously and peculiarly dangerous, of an infallible ear for rhythm, and a vast mine of fancy. Take the whole together; and we have a clue to the flaws of Alastor and its successors, and to their as extraordinary beauties too. The entire realm of poetry can show nothing so phenomenal. It was a strange universe, paradoxically monstrous, as paradoxically ideal, which spread before the poet's eyes. Turned back upon himself, he had fed upon, and held incessant communion with, his own imagination. He could at will be in the Tropics, fanned

With the breeze murmuring in the musical woods,

or in the Aegean isle,

Beautiful as a wreck of Paradise.

In a moment he passed in fancy from beauty to horror, from a June garden's

fresh odour, sent

From the turf, like the voice and the instrument, 
to its decay, weeds and toad-stools rotting
flake by flake,
Till the thick stalk stuck like a murderer's stake,
Where rags of loose flesh yet tremble on high,
Infecting the winds that wander by. ${ }^{1}$

It is not nature; it is a reflection of a picture discerned within, with some help from books, and projected into verse. So with the characters moving over the mirror his poems present. The reader sees nothing, none, that he has ever beheld, or that he supposes had ever been beheld. He feels that the narrator has chosen to imprison himself within his own spacious but tortuous being, and there and thence has spun a whole universe, Hell and Heaven, and chiefly Hell.

The voluminous works upon which, within a term not much prolonged beyond that of Adonais, he spent the uttermost of his extraordinary powers, demonstrate their own weight and compass. Consider, for instance, the Prometheus Unbound and the Cenci. The Prometheus raises tremendous problems, and only half, if at all, solves any of them. The hero of the drama is himself a problem unanswered. It is unintelligible why, if peace was to be made on the conditions hazily indicated, the conflict between him and Zeus need ever have arisen. Yet the Play, unsatisfactory as it essentially is, satisfies us sufficiently of its author's genius. In the conception it is as much a torso as an actual, confessed fragment, like the Hyperion of Keats. But it is colossal. In its ways of thought and style it is, moreover, an exact type of its author's common manner. The Cenci belongs to a different class altogether. It is a triumph, in the coldness of its horrors, over the temptation to its creator, being what he was, to burst through all the barriers of tragic art. The 
spirit is not Aeschylean; not Shakespearean. There is some analogy to Marlowe, only with more of the truly poetical. Alas ! for the ugliness of the theme !

The phenomenon is that, while it and the Prometheus are curiously unlike, both are absolutely and equally representative of their author in one essential respect. Independent as many poets are, determined to follow their own bias, even insolent to the reading world, they have an eye to it nevertheless; they evidently have weighed how they can most certainly render themselves audible to it. It would be difficult to match Shelley in the singleness of his regard to himself alone as he writes. Doubtless he would have liked to be popular. He never endeavoured to attain that end by consulting public tastes in the smallest particulars. He has general sympathies; not the sympathy which is at pains to comprehend a different point of view from one's own. Paradox as it seems, it is one of the explanations of the peculiar Shelley cult. Never was there a body of writings which to the initiated is a surer index of the author's mind, which admits reverent students, enamoured even of defects, to more intimate communion with it, for the very reason that it never appears to be looking to opinion outside. Had Shelley cared for external favour, he might have corrected diffuseness in diction and obscurity in ideas; he would have had a larger public, and fewer worshippers.

The serene unconsciousness that his readers have their likes and dislikes, which he might at least try to understand though without deferring to them, applies to all his work. He takes account so far of society about him as to lecture it on its shortcomings. He never learned that pity teaches how to cure. The apartness is the more instead of the less palpable that his inspiration constantly 
uses his fellow men for a text, yet accepts no light from them. Unless for adoration, of which we are not all capable, we cannot come close to his spirit.

Fortunately there were times when he sang as if to enjoy, not to denounce or awe. In moods of this class he sent forth a flight of exquisite songs, absolutely pure, ethereal, yet with warm blood coursing through every vein. Among them they represent all the beauties possible for the expression of regretful longing, bitter-sweet; the sharp-cut neatness and elegance of a Greek epigram; mystery, pathos, upbraiding, self-upbraiding. There are passionateness, self-restraint. Movement commonly is there ; sometimes, if very rarely, dancing joy, with cascades of breezy, glowing images. Music of words and rhythm never fails. Here are a few flowers, plucked as they come to my hand. I have not attempted to arrange them. They could not jar or clash, any more than colours in a bed of roses.

$\mathrm{He}$ has imagined an Indian lover serenading, perhaps Lalla Rookh :

I arise from dreams of thee

In the first sweet sleep of night,

When the winds are breathing low,

And the stars are shining bright;

I arise from dreams of thee,

And a spirit in my feet

Hath led me-who knows how ?

To thy chamber-window, Sweet !

The wandering airs they faint

On the dark, the silent stream-

And the Champak's odours fail

Like sweet thoughts in a dream;

The nightingale's complaint,

It dies upon her heart ;-

As I must on thine,

0 ! beloved as thou art ! 
$O$ lift me from the grass !

I die ! I faint ! I fail !

Let thy love in kisses rain

On my lips and eyelids pale.

My cheek is cold and white, alas !

My heart beats loud and fast ;-

$\mathrm{Oh}$ ! press it to thine own again,

Where it will break at last. ${ }^{2}$

Here is wreckage from the forgotten experiment of a drama on Charles the First :

A widow bird sate mourning for her love

Upon a wintry bough ;

The frozen wind crept on above,

The freezing stream below.

There was no leaf upon the forest bare,

No flower upon the ground, And little motion in the air

Except the mill-wheel's sound. ${ }^{3}$

What a spell-from old Hellas-is in Pan's piping!

From the forests and highlands

We come, we come ;

From the river-girt islands,

Where loud waves are dumb

Listening to my sweet pipings.

The wind in the reeds and the rushes,

The bees on the bells of thyme,

The birds on the myrtle bushes,

The cicale above in the lime,

And the lizards below in the grass,

Were as silent as ever old Tmolus was,

Listening to my sweet pipings.

Liquid Peneus was flowing,

And all dark Tempe lay

In Pelion's shadow, outgrowing

The light of the dying day,

Speeded by my sweet pipings. 


\section{THE POETS}

The Sileni, and Sylvans, and Fawns, And the Nymphs of the woods and waves, To the edge of the moist river-lawns, And the brink of the dewy caves, And all that did then attend and follow Were silent with love, as you now, Apollo,

With envy of my sweet pipings.

I sang of the dancing stars, I sang of the daedal Earth, And of Heaven-and the giant wars, And Love, and Death, and Birth,-

And then I changed my pipings,Singing how down the vale of Menalus I pursued a maiden and clasped a reed; Gods and men, we are all deluded thus !

It breaks in our bosom and then we bleed; All wept, as I think both ye now would, If envy or age had not frozen your blood, At the sorrow of my sweet pipings."

But his favourite mood was sorrowing for himself, sometimes softened by recollections of past happiness :

Music, when soft voices die,

Vibrates in the memory-

Odours, when sweet violets sicken,

Live within the sense they quicken.

Rose leaves, when the rose is dead,

Are heaped for the belovèd's bed;

And so thy thoughts, when thou art gone,

Love itself shall slumber on. ${ }^{5}$

more generally abetted, and embittered by the image of joys past recalling :

Rarely, rarely comest thou, Spirit of Delight!

Wherefore has thou left me now Many a day and night ?

Many a weary night and day

'Tis since thou art fled away. 
How shall ever one like me

Win thee back again ?

With the joyous and the free

Thou wilt scoff at pain.

Spirit false ! thou hast forgot

All but those who need thee not.

I love all that thou lovest, Spirit of Delight !

The fresh Earth in new leaves drest, And the starry night;

Autumn evening, and the morn

When the golden mists are born.

I love snow, and all the forms

Of the radiant frost ;

I love waves, and winds, and storms, Everything almost

Which is Nature's, and may be

Untainted by man's misery.

I love Love-though he has wings,

And like light can flee,

: But above all other things,

Spirit, I love thee-

Thou art love and life ! $O$ come,

Make once more my heart thy home. ${ }^{6}$

His almost solitary pleasure is to assure himself of his despair :

Oh, world ! oh, life ! oh, time !

On whose last steps I climb

Trembling at that where I had stood before ;

When will return the glory of your prime ?

No more-0, never more !

Out of the day and night

A joy has taken flight;

Fresh spring, and summer, and winter hoar,

Move my faint heart with grief, but with delight

No more-0, never more ! ? 
The power even to love is lost to him; and the one hope he has is that need of pity, and adoration of the giver, may be accepted as a substitute :

One word is too often profaned

For me to profane it,

One feeling too falsely disdained

For thee to disdain it.

One hope is too like despair

For prudence to smother,

And pity from thee more dear

Than that from another.

I can give not what men call love,

But wilt thou accept not

The worship the heart lifts above,

And the Heavens reject not,

The desire of the moth for the star,

Of the night for the morrow,

The devotion to something afar

From the sphere of our sorrow ? $^{8}$

Not even that such a shadow of passion may be too confidently reckoned as a permanent possession :

When the lamp is shattered

The light in the dust lies dead.

When the cloud is scattered

The rainbow's glory is shed.

When the lute is broken,

Sweet tunes are remembered not;

When the lips have spoken,

Loved accents are soon forgot.

As music and splendour

Survive not the lamp and the lute,

The heart's echoes render

No song when the spirit is mute :-

No song but sad dirges,

Like the wind through a ruined cell,

Or the mournful surges

That ring the dead seaman's knell.9 
The minstrel's theme indeed seldom is cheerful ; but the melody always is enchanting; and in that quality the specimens I have offered are very far from monopolizing the charms of their class. Many others are their equals. Some, which are too long to be set out at all fully, as well as too familiarly known to need recalling, are their superiors. I may instance the succession, almost dizzy, of glowing, glorious images dedicated to the Skylark. The whole is a golden staircase up which the song winds, step by step, heavenwards. ${ }^{10}$ From the wings of its sister The Cloud, itself 'nursling of the sky' :

Are shaken the dews that waken

The sweet buds every one,

When rocked to rest on their mother's breast, As she dances about the sun. ${ }^{11}$

Gloom characterizes the weird challenge-incantation he calls it-to the wild West Wind, 'dirge of the dying year.' 12 Arethusa, not foreseeing the rough wooing preparing for her by the river-god Alpheus, is, on the contrary, as joyous :

Gliding and springing

She went, ever singing,

In murmurs as soft as sleep ;

The Earth seemed to love her,

And Heaven smiled above her

As she lingered towards the deep. ${ }^{13}$

As for the poet himself, I do not suppose that he would even have understood the bestowal of praise for form and symmetry. In the apparent play of rhythm he was no more striving consciously to attract by the grace of superficial harmony than in the lamentation for Adonais, ${ }^{14}$ the Hymn to Intellectual Beauty, ${ }^{15}$ or the grandly intolerant Ode to Liberty. ${ }^{16}$ Search him through and through for depth, for essence, of thought; you will find nothing to

VOL. II 
beat the biting irony of the boast of Ozymandias; and where among his words for music is melody more sufficing than in that perfect sonnet?

I met a traveller from an antique land Who said : two vast and trunkless legs of stone Stand in the desart. Near them on the sand, Half sunk, a shattered visage lies, whose frown, And wrinkled lip, and sneer of cold command, Tell that its sculptor well those passions read Which yet survive, stamped on these lifeless things, The hand that mocked them, and the heart that fed : And on the pedestal these words appear: 'My name is Ozymandias, King of Kings : Look on my works, ye Mighty, and despair !' Nothing beside remains. Round the decay Of that colossal wreck, boundless and bare The lone and level sands stretch far away. ${ }^{17}$

Simply his impulse, the current of his spirit, happened to use the same channel as common human feeling. He desired to express an emotion or conception; and by chance it was definite enough not to need to stretch and strain his native instinct of ear. The coincidence was a happy one for the outside world. That must not flatter itself that the fanatic of ideas meant to sacrifice the least of them to its pleasure. From first to last he was constantly self-centred, whether meditating flaws in the Universe, or a cloud in its airy nest; in a song, "When the lamp is shattered,' as much as in one to the Skylark; in both as in the stark agony of the Cenci ; in the lilting of the Hymn of Pan as in that to Intellectual Beautynot the less profound that it is as lovely also as

music by the night-wind sent Thro' strings of some still instrument, Or moonlight on a midnight stream ! ${ }^{18}$ 
He has painted pictures we can see with our eyes shut; of the Pisan pine forest, where

the multitudinous

Billows murmur at our feet,

And the earth and ocean meet; ${ }^{19}$

and of the Euganean Hills, in

the noon of autumn's glow,

When a soft and purple mist

Like a vaporous amethyst,

Or an air-dissolvèd star

Mingling light and fragrance, far

From the curved horizon's bound

To the point of heaven's profound,

Fills the overflowing sky.-20

While he gazed and composed, he was dwelling still as apart in his own fancy, as when lost in the labyrinthine enigmas of Prometheus Unbound. Lovers of poetry who would know of what highest rapture the Muse has the secret, must be content to accept Shelley for that he is. They must not mind that he sings for himself, not to them. On the other hand, they cannot be inhibited from hearing him, though they have not bought the privilege by studying Julian and Maddalo, with its madman's reverie, or a single line of Epipsychidion. At least Gentiles are free to follow the glow of the lamps which devotees keep burning at the shrine. Standing outside the sanctuary they can listen to lyrics which will vibrate for them as directly from the soul of Shelley-gathered to the Kings of thought-as, for his worshippers, rolls forth the full diapason of pieces like The Revolt of Islam and The Witch of Atlas, hurled against the world as it exists, and its government.

The Poetical Works of Percy Bysshe Shelley, edited by Harry Buxton Forman. Four vols. Reeves and Turner, 1876. 
1 The Sensitive Plant, Part I, vv. 15-16, vol. ii, p. 268 ; and Part III, vv. 66-9, p. 277.

2 The Indian Serenade, vol. iv, pp. 10-12.

3 Charles the First, Sc. 5, vol. iii, p. 326.

- Hymn of Pan, vol. iv, pp. 36-7.

5 To -

- Song, stanzas 1, 2, 5, 6, 8, vol. iv, pp. 77-9.

- A Lament, vol. iv, p. 82.

To -

- Lines, stanzas 1-2, vol. iv, pp. 131-2.

10 To a Skylark, vol. ii, pp. 299-304.

11 The Cloud, vv. 5-8, vol. ii, p. 296.

12 Ode to the West Wind, vol. ii, pp. 290-3.

13 Arethusa, st. 1, vol. iv, p. 29.

14 Adonais (Elegy on the Death of John Keats), vol. iii, pp. 9-29.

${ }^{25}$ Hymn to Intellectual Beauty, vol. i, pp. 371-5.

${ }^{26}$ Ode to Liberty, vol. ii, pp. 305-15.

${ }^{17}$ Ozymandias, vol. i, p. 376.

${ }^{18}$ Hymn to Intellectual Beauty, st. 3, vol. i, p. 373.

19 To Jane, Invitation to the Pine Forest, vv. 65-7, vol. iv, p. 135.

${ }^{20}$ Lines, Written among the Euganean Hills, vv. 286-93, vol. i, p. 368. 


\section{JOHN KEA'TS}

\section{$1795-1821$}

ENDymion surprised and shocked the lingering orthodoxy of late Georgian critics. Its author provoked as much animosity as Wordsworth, and more than Byron. Wordsworth bore no relation to the idols of their youth, Dryden and Pope. Byron, and Scott also, affected to revere both. Shelley reviewers simply did not understand. Endymion was the worst of rebels. It had borrowed and travestied myths of the Greek Classics, and the metre of English Masters. Many real faults indeed may be found in it. The plot wanders, and perpetually loses itself. The narrative, often the descriptions, are prolix and tedious. The diction is troubled with strange words and phrases. The rhyme tends to lead the sense. Not rarely the ideas are thin in comparison with the parade of the circumstances meant to wait upon them. Occasionally the prosaic will obtrude itself; cotton-backing showing under rich velvet pile. But then the golden autumnal haze, the delicious uncertainty what visions of romance will next come and go from and into happy Dreamland! The age was one of muddy perturbation-strifes of peoples against kings, and kings against peoples, of mortal struggles between agrarianism and feudalism, labour and capital, political economy and an outworn Faith. Imagine, for the few non-combatants, the joy in this pageant of Olympian goddesses haunting the happy pastures of Arcadian hills !

It is in truth an Elizabethan poet's world. The Elizabethan idea of poetry breathes throughout. Laws of 
physical nature are suspended. Men ride on eagles' wings, walk the sea, and sojourn in ocean caves. No whisper of wranglings of statesmen, discontents, and hunger of the seething masses, stirs the serene solitude. Fields and woodlands are governed by no human law, and need none. The cares are not of a kind to be inflamed or lulled by the lyre of a Tyrtaeus. The author of Endymion had drunk deep from the fountains of Sidney, Spenser, and Browne; of Shakespeare-the singer of Venus and Adonis, of Lucrece, and the Sonnets. He had learnt to move in an upper air of his own, as they in theirs. Where, in his models, a tincture of a purpose had intervened, he stopped short. He would have abhorred to enlist, like his beloved Spenser, the Muse in the service of a moral allegory. For him poetry was no minister to duty, as understood outside. No painful requisition of self-denial was imposed upon it by the laws of its being. Endymion, without a sting of the conscience framed for poetic use on peculiar lines, might banish back to the skies his dreammistress. He is not liable to a shadow of reproach for wooing and winning, before he was properly off with the old love, a dusky and more tangible mate:

No more of dreaming.-Now, Where shall our dwelling be ? ${ }^{1}$

For poets in general the one inspiring motto is :

A thing of beauty is a joy for ever ; ${ }^{2}$

for the universe, the eternal law

That first in beauty should be first in might; 3

and for himself :

Beauty is truth, truth beauty-that is all

Ye know on earth, and all ye need to know. 4

The whole is immature. Had Keats lived to nurse his 
fame, not impossibly he might have wished to suppress the poem. For students of literature it is invaluable. Were it practicable to analyse the products of genius like food, an investigation of his later verse probably would prove that to share much of the essence of its perfection with this very imperfect original. An identical spirit pervades all his work; though how the mellowing rays of two or three summers added colour! How the lines were harmonized, taste and odour developed! On the poet's youthfulness throughout his entire career I do not care to dwell. That, I have constantly held, is an element of small importance in any estimate of merit of a great writer. It does not concern his public whether verse or prose date from boyhood or old age. The one question is of the intrinsic worth. With Keats least of all is the point material. In none of his acknowledged poems after Endymion,

a young bird's flutter from a wood,

can the minutest indication of juvenility be traced. With it he laid aside all crudity of sentiment, all excess even of sensuousness. He kept of it warmth and fire, luxuriance of fancy no longer rank, vividness and enthusiasm. $\mathrm{He}$ added a dainty moral delicacy, and moderation. The degrees of relationship among their several works radically distinguish some poets of high eminence from others. Between Hours of Idleness and Childe Harold I see no affinity. I perceive much between Queen Mab and Alastor, as between both and Prometheus Unbound. I see yet more between Endymion and the Ode to a Nightingale. There I recognize almost lineal descent. It would be hard for me to believe that those brimming pools of imaginationthe Nightingale, the Grecian Urn, Autumn, Melancholy, the Mermaid Tavern, Fancy, the Poets, the Songs, In 
a drear-nighted December, and Shed no Tear ! the sonnet on Chapman's Homer, The Eve of St. Agnes, Isabella, Lamia, and Hyperion-could ever have been born, unless the imagination which created them had undergone the previous experience of dreaming Endymion!

Endymion is rife with miscellaneous sweetness, and in that proved a fitting herald and seed-bed for the various ripe fruit to follow. It may almost be said that never was so much unmixed charm in fancy and in melody collected into the same compass as in the single volume of Keats's life-work. All that is needed for entire enjoyment by a reader is acceptance of his aim, with its limits; of his worship of Beauty; and, almost equally, of Melancholy, dainty Melancholy. Her he wooes coyly, economizing her sweets, which, culled hastily, have a tendency to waste them. selves in a narcotic flood:

For shade to shade will come too drowsily,

And drown the wakeful anguish of the soul.

But when the melancholy fit shall fall

Sudden from heaven like a weeping cloud,

That fosters the droop-headed flowers all,

And hides the green hill in an April shroud;

Then glut thy sorrow on a morning rose,

Or on the rainbow of the salt sand-wave,

Or on the wealth of globed peonies.

She dwells with Beauty-Beauty that must die ;

And Joy, whose hand is ever at his lips

Bidding adieu ; and aching Pleasure nigh,

Turning to poison while the bee-mouth sips;

Ay, in the very temple of Delight

Veil'd Melancholy has her sovran shrine,

Though seen of none save him whose strenuous tongue

Can burst Joy's grape against his palate fine ;

His soul shall taste the sadness of her might, And be among her cloudy trophies hung." 
Melancholy is the keynote of his singing; a shadow ever hanging over him; not the less saddening that it was so familiar as to be made a playmate. Naturally he finds Autumn more companionable than Spring. He delights in its slumberous calm :

Season of mists and mellow fruitfulness !

Close bosom-friend of the maturing sun;

Conspiring with him how to load and bless

With fruit the vines that round the thatch-eaves run ;

To bend with apples the moss'd cottage trees,

And fill all fruit with ripeness to the core.

Who hath not seen thee oft amid thy store?

Sometimes whoever seeks abroad may find

Thee sitting careless on a granary floor,

Thy hair soft-lifted by the winnowing wind;

Or on a half-reap'd furrow sound asleep,

Drowsed with the fume of poppies, while thy hook

Spares the next swath and all its twined flowers;

And sometime like a gleaner thou dost keep

Steady thy laden head across a brook;

Or by a cider-press, with patient look,

Thou watchest the last oozings, hours by hours.

Where are the songs of Spring ? Ay, where are they ?

Think not of them, thou hast thy music too,

While barred clouds bloom the soft-dying day,

And touch the stubble-plains with rosy hue;

Then in a wailful choir the small gnats mourn

Among the river sallows, borne aloft

Or sinking as the light wind lives or dies ;

And full-grown lambs loud bleat from hilly bourn;

Hedge-crickets sing; and now with treble soft

The red-breast whistles from a garden-croft,

And gathering swallows twitter in the skies. ${ }^{6}$

If mirth, as very rarely, inspired him, it is not very distinguishable from sadness. By choice it is that of the bygone past ; echoes from 


\section{THE POETS}

Souls of poets dead and gone ?,

reposing

\section{on Elysian lawns}

Browsed by none but Dian's fawns ;

Underneath large blue-bells tented,

Where the daisies are rose-scented;

Where the nightingale doth sing

Not a senseless, tranced thing,

But divine melodious truth;

Philosophic numbers smooth;

Tales and golden histories

Of heaven and its mysteries ; 8

Yet still betimes sighing to one another :

What Elysium have we known,

Happy field or mossy cavern,

Choicer than the Mermaid Tavern ? 9

Or it may be monumental gaiety; imprisoned in sculptured stone, imprisoning funeral ashes :

What leaf-fringed legend haunts about thy shape

Or deities or mortals, or of both,

In Tempe, or the dales of Arcady?

What men or gods are these? What maidens loath ?

What mad pursuit? What struggle to escape ?

What pipes and timbrels ? What wild ecstasy?

Heard melodies are sweet, but those unheard

Are sweeter ; therefore, ye soft pipes, play on ;

Not to the sensual ear, but, more endear'd,

Pipe to the spirit ditties of no tone ;

Fair youth, beneath the trees, thou canst not leave

Thy song, nor ever can those trees be bare ;

Bold Lover, never, never canst thou kiss,

Though winning near the goal-yet, do not grieve ;

She cannot fade, though thou hast not thy bliss,

For ever wilt thou love, and she be fair !

Who are these coming to the sacrifice ?

To what green altar, 0 mysterious priest, 
Lead'st thou that heifer lowing at the skies, And all her silken flanks with garlands drest ?

What little town by river or sea-shore,

Or mountain-built with peaceful citadel,

Is emptied of its folk, this pious morn ?

And, little town, thy streets for evermore

Will silent be ; and not a soul to tell

Why thou art desolate, can e'er return. ${ }^{10}$

Melancholy still, after all, with its frozen revelry; yet not so lingeringly, hauntingly saddening as the full life of the Nightingale song :

My heart aches, and a drowsy numbness pains

My sense, as though of hemlock I had drunk,

Or emptied some dull opiate to the drains

One minute past, and Lethe-wards had sunk ;

'Tis not through envy of thy happy lot,

But being too happy in thy happiness, -

That thou, light-winged Dryad of the trees,

In some melodious plot

Of beechen green, and shadows numberless,

Singest of summer in full-throated ease.

Darkling I listen; and for many a time

I have been half in love with easeful Death, Call'd him soft names in many a mused rhyme,

To take into the air my quiet breath ;

Now more than ever seems it rich to die,

To cease upon the midnight with no pain,

While thou art pouring forth thy soul abroad

In such an eestasy!

Still wouldst thou sing, and I have ears in vain-

To thy high requiem become a sod.

Thou wast not born for death, immortal Bird!

No hungry generations tread thee down;

The voice I hear this passing night was heard

In ancient days by emperor and clown : 
Perhaps the self-same song that found a path

Through the sad heart of Ruth, when, sick for home,

She stood in tears amid the alien corn ;

The same that oft-times hath

Charm'd magic casements, opening on the foam

Of perilous seas, in faery lands forlorn.

Forlorn ! the very word is like a bell

To toll me back from thee to my sole self !

Adieu ! the fancy cannot cheat so well

As she is famed to do, deceiving elf.

Adieu ! adieu ! thy plaintive anthem fades

Past the near meadows, over the still stream,

Up the hill-side; and now 'tis buried deep

In the next valley-glades :

Was it a vision, or a waking dream ?

Fled is that music :-do I wake or sleep ? ${ }^{11}$

Marvels all ! And we may add to them another marvel, the consummate art of the Chapman-Homer sonnet:

Much have I travell'd in the realms of gold,

And many goodly states and kingdoms seen :

Round many western islands have I been

Which bards in fealty to Apollo hold.

Oft of one wide expanse had I been told

That deep-brow'd Homer ruled as his demesne :

Yet did I never breathe its pure serene,

Till I heard Chapman speak out loud and bold :

Then felt I like some watcher of the skies

When a new planet swims into his ken :

Or like stout Cortez when with eagle eyes

He stared at the Pacific-and all his men

Look'd at each other with a wild surmise-

Silent, upon a peak in Darien. ${ }^{12}$

Had he written no more than such a sonnet and such odes, he must have ranked among the highest in song. But he found time in his brief and sorely tried span of life to work on larger canvases, and never without a triumph. 
The Eve of St. Agnes, Isabella, Lamia, Hyperion, breathe, all four, of the same creative soul. Each is radiantly distinct. Among their many brilliant qualities not the least amazing is, for the proximity in the dates of their birth, this absolute variety.

Exquisiteness of detail, always harmonious, characterizes the first. Many a painter could testify, not without a pang, how provocative is the poet's challenge to work up to the glowing frame in which he has set his sweet Madeline, and how unequal the competition :-

A casement high and triple-arch'd there was, All garlanded with carven imageries

Of fruits, and flowers, and bunches of knot-grass, And diamonded with panes of quaint device, Innumerable of stains and splendid dyes, As are the tiger-moth's deep-damask'd wings ; And in the midst, 'mong thousand heraldries, And twilight saints, and dim emblazonings, A shielded scutcheon blush'd with blood of queens and kings.

Full on this casement shone the wintry moon, And threw warm gules on Madeline's fair breast, As down she knelt for heaven's grace and boon ; Rose-bloom fell on her hands, together prest, And on her silver cross soft amethyst, And on her hair a glory, like a saint ; She seem'd a splendid angel, newly drest, Save wings, for heaven :-Porphyro grew faint ; She knelt, so pure a thing, so free from mortal taint.

Soon, trembling in her soft and chilly nest, In sort of wakeful swoon, perplex'd she lay, Until the poppied warmth of sleep oppress'd Her soothed limbs, and soul fatigued away;

Flown, like a thought, until the morrow day; Blissfully haven'd both from joy and pain ; Clasp'd like a missal where swart Paynims pray; Blinded alike from sunshine and from rain, As though a rose should shut, and be a bud again. ${ }^{13}$ 
Another, and wholly different, note is struck, still with its delicately suitable accompaniments, in the piteous story of Isabella. Not that aught is allowed to obscure the central figure, almost the peer of Chaucer's Griselda ; she bows to the storm of fraternal vengeance on her humble lover, forlorn, tender, unvindictive, and patient, except for the one cry of heart-break :

' for cruel 'tis,' said she,

'To steal my Basil-pot away from me.' 14

In Lamia, on the other hand, it is the plot, rather than the circumstances, or the figures, on which attention is concentrated. On the tale moves to its catastrophe, mysterious, yet foreseen, inevitable, austere, stately, like a great mediaeval noble, in velvet and lace, on his way to Tower Hill. ${ }^{15}$

And finally, the palace door of Keats's splendid fancy flies open for the god-Hyperion-to pass within :

He enter'd, but he enter'd full of wrath ;

His flaming robes stream'd out beyond his heels, And gave a roar, as if of earthly fire,

That scared away the meek ethereal Hours And made their dove-wings tremble. On he flared, From stately nave to nave, from vault to vault, Through bowers of fragrant and enwreathed light, And diamond-paved lustrous long arcades, Until he reach'd the great main cupola ; There, standing fierce beneath, he stampt his foot, And from the basements deep to the high towers Jarr'd his own golden region; and before The quavering thunder thereupon had ceased, His voice leapt out, despite of godlike curb, To this result : ' $O$ dreams of day and night !

$\mathbf{O}$ monstrous forms ! $\mathbf{O}$ effigies of pain !

$\mathrm{O}$ spectres busy in a cold, cold gloom !

0 lank-ear'd Phantoms of black-weeded pools ! 
Why do I know ye ? why have I seen ye ? why

Is my eternal essence thus distraught

To see and to behold these horrors new ?

Saturn is fallen, am I too to fall ?

Fall !-No, by Tellus and her briny robes !

Over the fiery frontier of my realms

I will advance a terrible right arm

Shall scare that infant thunderer, rebel Jove,

And bid old Saturn take his throne again.' 16

Standing forth from the rest with their dainty finishas of a butterfly fresh from the chrysalis, perfect to the least plume of down-the poem confronts us; a torso, almost a gallery of torsos, which could never have been anything else, as, like its own Sun-God, it enthroned itself

Upon the gold clouds metropolitan

of its creator's brain; yet the grandest, most majestic, conception of all the four!

With this exception-which proves the rule, for nothing is so perfect in its imperfectness-no quality is more conspicuous in Keats than completeness of workmanship. That stands out from the multitude of admirable properties in the galaxy of his poems-tales, odes, songs, sonnets, ballads. Imagination is always satisfied, and, after Endymion, never cloyed. Atmosphere, lights, shades, perspective, are all in their right places. If traced

with the magic hand of chance,

it is because chance in ministering to genius is indistinguishable from supreme art. Loath as I am to emphasize in a master poet quickness of execution any more than youth, I cannot but remember that four years conclude the fruitful season of Keats's career. Never has either happy chance, or unsparing brainwork, done more in an 
equal term for English poetry. An artist in every line; and dead in despair at failure at twenty-six !

I should myself be sorry, I confess, if the waters of England's Helicon were such alone as Keats drew up. Temples dedicated to the exclusive worship of the Goddess Beauty are apt to be served by sordid ministers. The deity they adore is often a tawdry nymph. Fanes of the Muses ought to be veritable Pantheons, with room for shrines of all the Graces and Virtues. Tenderness, Lovingkindness, Heroism, Faith, and innocent Joy have a right to make their home there; and a Chapel should be consecrated to Sorrow. Not all in Keats's ideal loveliness is real. Many of the supposed classic forms rising from his pages, their locks dewy with liquid unguents, their ivory lips and cheeks made to blush rosy-red as over-animated flesh, are exhalations of a feverish fancy. The sturdy frequenters of the Mermaid might have mocked at some of the magically wrought phantasms. Too much of the landscape is scene-painting. Rude botanists would scoff at the fairy forests and garden-land of the exiled Titans. No lark carols here with the freshness of the Ayrshire ploughman's. The Muse is bidden to keep company with sculptured funeral urns and the sweet-spiced ashes therein, instead of kindling living hearts.

But I repent. Let me be forgiven for having been tempted to dwell on a sombre truism, which, after all, is only a half-truth. Side by side with it stands, as I gladly acknowledge, another, that genius has manifold forms. One poet now and then may be spared from the dull haunts of men to roam, enchanted and enchanting, through moonlit forest glades. It is good to be reminded from time to time that the duty of poetry is not to sew and spin; its first obligation, to be fulfilled on pain of being 
not poetry at all, is to be beautiful as a lily of the field. Keats was born in an age of brute military force. Humanity had been vulgarized by political panic or ambition. Ideas with no money or physical power in them were despised. His nature revolted in disgust. In defiance he set up the image of Beauty to be worshipped. At least the service carried men outside their own poor selves; it fascinated, and refined. Who, old or young, can recall the first revelation to him of The Eve of St. Agnes, the Nightingale Ode, Hyperion, without feeling how, while he read, an ocean seemed to roll illimitably before his eyes, as the Iliad, a new planet, swam into the ken of John Keats !

The Poetical Works of John Keats: with a Memoir by Richard Monckton Milnes. New Edition. E. Moxon, 1854.

1 Endymion, Book IV, p. 192.

${ }^{3}$ Hyperion, Book II, p. 303.

- Ode on Melancholy, p. 252.

' Lines on the Mermaid Tavern, p. 253.

- Lines on the Mermaid Tavern, p. 253.

10 Ode on a Grecian Urn, stanzas 1, 2, 4, pp. 242-3.

"Ode to a Nightingale, stanzas 1, 6, 7, 8, pp. 239-41.

${ }^{12}$ On First Looking into Chapman's Homer, p. 290.

${ }_{13}$ The Eve of St. Agnes, stanzas 24, 25, 27, pp. 178-9.

14 Isabella ; or, The Pot of Basil, st. 62, p. 168.

${ }^{15}$ Lamia, pp. 129-50.

${ }^{16}$ Hyperion, Book I, pp. 191-2. 


\section{CHARLES WOLFE}

\section{$1791-1823$}

I HAD doubted whether to assign a place to Wolfe's poems rather than to him. Finally, I decided that his nature was too much of a poem for his work not to be classed by his personality. In his schoolboy days at Winchester he was a poet. His lines on the raising of Lazarus show distinct poetic insight. Their note is the feeling of Jesus ' for others' grief' :

He knew what pains must pierce a sister's heart. ${ }^{1}$

It is the same with his prize poem on the Death of Abel :

Nor could his lips a deep-drawn sigh restrain,

Not for himself he sigh'd-he sigh'd for Cain. ${ }^{2}$

Throughout a brilliant career at Trinity, Dublin, it was as a poet that he was particularly recognized. An old air could not sound in his ears without hastening to embody itself in melodious verse. His few songs, the poem itself by which he is immortalized, were emotions translated instantly into language. His biographer, who cannot be accused of poetical enthusiasm, describes the effect of music upon his imagination: 'he felt all its poetry; it transported him.' The same friend recollects how, captivated by a national Spanish air, Viva el Rey Fernando, he 'commenced singing it over and over again, until he produced an English song admirably suited to the tune '? He had music in his heart.

There, after the close of his College career, it stayed, 
mute, but a sweetening influence. It would be romantic to lay down purity in act as a necessary condition of poetic power. Unfortunately a high sensibility constantly tends to lead astray. Not the less true is it that delicacy of feeling, shrinking from grossness of every sort, generosity, and an ideal capacity for friendship, make the poetry of life. They had always been the essence of Wolfe's, while he still sang. Self-sacrifice caused him to abandon, from fear of paining his mother, early thoughts of the Army. Later, religious devotion led him to abjure versifying. When he cast himself outside his academic circle of worshippers, his passion of charity sustained him in the grim solitude of his curacy in Tyrone. There it won him the equal adoration of three mutually hostile types of so-called Christianity, agrecing only in common hatred of a fourth, the one he was bound to represent. The good Archdeacon, to whom we owe the sketch of his career, portrays the beautiful modesty, simplicity, piety, sympathy, courage, of the youth with all gentle, well-bred tastes and habits, in his new home, a peasant's cabin. Poetizing, the 'mere inspiration of the Muse', the Archdeacon treats as 'the less important, the less serious' phase of his character. In truth Wolfe was doubtless as essentially a poet in the wilds of Tyrone and Donoughmore as in his Scholar's rooms in Trinity. The splendour of fancy glorified his ruinous, mouldy cottage, and inspired the consolation he carried to many a typhus-stricken hut.

His was a noble spirit, entirely consistent with a poet's, yet not in itself necessarily implying it. I am sensible accordingly of the need for an apology when I number him with poets by profession. Obviously I cannot justify it on the ground of virtues happily not a monopoly of any special vocation. I have to rely on his poetical inspiration ; 
and his fits of that, I am aware, are, as evidenced in print, to be measured less by years, than by months or weeks, perhaps by days and hours. The actual bulk of his entire poetical production is scanty indeed. Apart from school and college exercises, it consists of half a dozen songs. Several are pretty and graceful. Yet, on their own merits, I could not claim that they would have survived even their author's brief existence. What then remains? Why, beside, rather than among, the meagre rest, just two of the loveliest flowers in the garden of English verse !

The entire Anglo-Saxon world is familiar with the poem on the Burial of Sir John Moore. If I give it here in full, it chiefly is for convenience of comparison with another piece by Wolfe as admirable in a different way:

Not a drum was heard, not a funeral note As his corse to the rampart we hurried;

Not a soldier discharged his farewell shot

O'er the grave where our hero we buried.

We buried him darkly at dead of night, The sods with our bayonets turning, By the struggling moonbeam's misty light And the lanthorn dimly burning.

No useless coffin enclosed his breast,

Not in sheet or in shroud we wound him ;

But he lay like a warrior taking his rest With his martial cloak around him.

Few and short were the prayers we said, And we spoke not a word of sorrow ;

But we steadfastly gazed on the face that was dead, And we bitterly thought of the morrow.

We thought as we hollow'd his narrow bed And smoothed down his lonely pillow, That the foe and the stranger would tread o'er his head, And we far away on the billow ! 
Lightly they'll talk of the spirit that's gone, And o'er his cold ashes upbraid him-

But little he'll reck if they let him sleep on

In the grave where a Briton has laid him.

But half of our heavy task was done

When the clock struck the hour for retiring;

And we heard the distant and random gun

That the foe was sullenly firing.

Slowly and sadly we laid him down,

From the field of his fame fresh and gory;

We carved not a line, and we raised not a stone,

But we left him alone with his glory.

The whole had flashed out of a casual glance at a flinty paragraph in a superannuated number of the Edinburgh Annual Register. Byron, whose sympathetic eyes it first caught, through no self-advertising by the author, accounted it 'little inferior to the best the present age had brought forth '.5 The third stanza in particular drew from him the exclamation, 'Perfect!' The unpremeditated art itself is excellent. Observe, for example, how the seventh labours in instinctive sympathy with the burden. In absoluteness of pictorial effect the poem has few equals in its kind, no superior. The precise correspondence of the details with the prose narrative, which has been urged in depreciation, in fact greatly enhances the merit. Wolfe's version is identical with its source, except that a soul has been added.

In the lines To Mary the process is, after a manner, reversed. Wolfe found an air of melancholy beauty, Gramachree, deformed by alien, commonplace words. $\mathrm{He}$ gave it back its proper significance. In tone and character the song, while matching the Burial of Sir John Moore in loveliness, is, it will, I think, be recognized, so generally 
distinct as to indicate that, in Wolfe's poetical career, the phenomenon, the accident, is not his authorship of a couple of paragons of melody, but his omission to add a score of equal marvels :

If I had thought thou couldst have died,

I might not weep for thee ;

But I forgot, when at thy side,

That thou couldst mortal be ;

It never through my mind had past

The time would e'er be o'er, And I on thee should look my last,

And thou shouldst smile no more.

And still upon that face I look, And think 'twill smile again ;

And still the thought I will not brook,

That I must look in vain !

But when I speak-thou dost not say,

What thou ne'er left'st unsaid ;

And now I feel, as well I may,

Sweet Mary! thou art dead.

If thou wouldst stay, e'en as thou art,

All cold and all serene-

I still might press thy silent heart, And where thy smiles have been!

While e'en thy chill, bleak corse I have, Thou seemest still mine own;

But there-I lay thee in thy grave,And I am now alone !

I do not think, where'er thou art, Thou hast forgotten me ;

And I, perhaps, may soothe this heart In thinking, too, of thee ;

Yet, there was round thee such a dawn

Of light ne'er seen before,

As fancy never could have drawn,

And never can restore ! 6 
In its origin this was at once as spontaneous, and as compulsory, as the other. And yet the unconscious art with which, in the second half of the final stanza, the thought starts, and gleams! Wolfe told an acquaintance that it referred to no real being or incident. Simply he had, as with the Viva el Rey, sung the air over and over, till he burst into a flood of tears, and in that mood wrote.

Both there, and in the genealogy of the Dirge, we have the man; a composite of elements, loftiness, tenderness, sympathy, instinct-the whole a poet. That he was to the end, when, after two years of wasting consumption, he whispered to the affectionate watcher of his death-bed with what almost seems pathetic humour: 'Close this eye, the other is closed already ; and, now, farewell !'

Remains of the late Rev. Charles Wolfe, A.B., Curate of Donoughmore, Dioceses of Armagh : with a brief memoir of his life, by the Rev. John Russell, M.A., Archdeacon of Clogher. Seventh edition. London : Hamilton, Adams \& Co., 1838.

1 Jesus Raising Lazarus, p. 352.

3 Memoir (Remains), pp. 28-9.

2 On the Death of Abel, p. 355.

4 Remains, pp. 23-4.

s Medwin's Conversations of Byron, vol. ii, p. 154, second edition.

- Remains. 


\section{HENRY HAR'T MILMAN}

\section{$1791-1868$}

I REMEMBER to have heard from persons old when even I was young, that the sensation stirred by Milman's sacred dramas was comparable with that which attended the appearance of a new poem by Byron. He was hailed as a living proof of the compatibility of poetic genius with religion by the orthodox who were soon to ban him as a schismatic. The enthusiasm subsided sooner than the hostility. It, perhaps they, had a solid foundation in the fact of the great brain and brave heart of their object. He never wrote, whether verse, or history, without the promptings of deep thought and a strong dramatic instinct. From youth upwards he possessed and displayed taste, fancy, a fine ear, thirst for knowledge, and a resolute combativeness.

He leapt into fame with his Newdigate prize for the Apollo Belvidere. Some of the lines are never likely to be forgotten ; for instance :

Heard ye the arrow hurtle in the sky ?

Heard ye the dragon monster's deathful cry ?

In settled majesty of fierce disdain,

Proud of his might, yet scornful of the slain,

The heav'nly Archer stands-no human birth,

No perishable denizen of earth ;

Youth blooms immortal in his beardless face,

A god in strength, with more than godlike grace ;

All, all divine-no struggling muscle glows,

Through heaving vein no mantling life-blood flows,

But animate with deity alone,

In deathless glory lives the breathing stone. 
Beauteous as vision seen in dreamy sleep By holy maid on Delphi's haunted steep, Mid the dim twilight of the laurel grove, Too fair to worship, too divine to love. ${ }^{1}$

But the whole brief poem, excepting the conclusion with its sickly sentimentality, is almost faultless. The Judicium Regale, composed in anticipation of the visit of the Allied Sovereigns to England, followed. Its rhetoric approaches grandeur, notwithstanding that it also has its flaw in an ungenerous vindictiveness towards a fallen foe. Already he virtually had completed Samor, Lord of the Bright City, commenced when he was a lad at Eton. The epic abounds in vivid dramatic situations, like the sonorous narrative of King Argantyr's surrender to Samor. Its weakness is a juvenile inclination to rioting in horrors. An instance, by no means exceptional, is the sacrifice by Caswallon's savage ambition to the Gods of Valhalla of his only daughter. He had left her to grow up as a wild flower by Derwent's blue lake :

Like a forgotten lute, play'd on alone By chance-caressing airs. ${ }^{2}$

The grotesque extravagances themselves, however, testify to power. The whole, in its prodigal expenditure of effects, lurid splashes of colour on acres of canvas, and audacious defiances of history, might well have been material for the growth of a mighty poet.

From the same source issued, in fact, one secular and three religious plays, all of distinction; and then, in place of the poet, a philosophic historian. Fazio is a piece for the stage ; and accomplished actors have acknowledged its merits as such. The others in dramatic form are essentially poems, and as such to be judged. They have undergone the proper refining from the noisiness, the violence, the absurdities of 
the boyish epic. Half a century ago the reading public admired the awe, the pity, of Titus meditating, at the head of his army, over doomed Jerusalem :

How boldly doth it front us ! how majestically !

Like a luxurious vineyard, the hill-side

Is hung with marble fabrics, line o'er line ;

While over all hangs the rich purple eve, As conscious of its being her last farewell

Of light and glory to that fated city.

And, as our clouds of battle dust and smoke

Are melted into air, behold the Temple,

In undisturb'd and lone serenity

Finding itself a solemn sanctuary

In the profound of Heaven !

By Hercules ! the sight might almost win

The offended majesty of Rome to mercy. ${ }^{3}$

It was moved by the prayer-a demand-of defiant Hebrew maidens to Jehovah to repeat against insolent Rome His judgement upon Egypt and her furious King :

The Lord from out His cloud, The Lord look'd down upon the proud ;

And the host drave heavily

Down the deep bosom of the sea.

With a quick and sudden swell

Prone the liquid ramparts fell ;

Over horse, and over car,

Over every man of war,

Over Pharaoh's crown of gold,

The loud thundering billows roll'd.

As the level waters spread,

Down they sank, they sank like lead.

Down without a cry or groan.

And the morning sun that shone

On myriads of bright-armed men,

Its meridian radiance then

Cast on a wide sea, heaving as of yore,

Against a silent, solitary shore. ${ }^{4}$ 
The contrast of Christian Miriam's appeal to a merciful Redeemer equally charmed :

For thou wert born of woman! thou didst come,

$\cap$ Holiest ! to this world of sin and gloom,

Not in thy dread omnipotent array ;

And not by thunders strew'd

Was thy tempestuous road;

Nor indignation burnt before thee on thy way.

But thee, a soft and naked child,

Thy mother undefiled,

In the rude manger laid to rest

From off her virgin breast.

The heavens were not commanded to prepare

A gorgeous canopy of golden air ;

Nor stoop'd their lamps th' enthroned fires on high :

A single silent star

Came wandering from afar,

Gliding uncheck'd and calm along the liquid sky. ${ }^{5}$

If the Fall of Jerusalem was not obsolete in my boyhood, much less had the Martyr of Antioch lost its powers of fascination. Readers of poetry would have been ashamed to confess ignorance of the converted priestess's vision of Heaven opened :

What means yon blaze on high ?

The empyrean sky

Like the rich veil of some proud fame is rending.

I see the star-paved land

Where all the angels stand,

Even to the highest height in burning rows ascending.

Beyond ! ah, who is there

With the white snowy hair ?

'Tis $\mathrm{He}-$ 'tis $\mathrm{He}$, the Son of Man appearing !

At the right hand of One

The darkness of whose throne

That sun-eyed seraph Host behold with awe and fearing. 
O'er him the rainbow springs,

And spreads its emerald wings,

Down to the glassy sea his loftiest seat o'erarching.

Hark-thunders from his throne, like steel-clad armies marching -

The Christ ! the Christ commands us to his home !

Jesus, Redeemer, Lord, we come, we come, we come ! 6

It was recognized as a touch of genius when the beauteous martyr, in the very ecstasy of visible acceptance within the celestial halls, manœurres to spare her aged heathen father the agony of seeing his daughter's blood:

A quick and sudden cry

Of Callias, and a parting in the throng

Proclaim'd her father's coming. Forth she sprang

And clasp'd the frowning headsman's knees, and said-

'I do beseech thee, slay me first and quickly;

'Tis that my father may not see my death !?

Inspiration, indeed, I for one still feel animates the entire substance of the dramas which have furnished me with my examples. A public satisfied to know Milman from an occasional fragment used as a hymn, like the famous funeral anthem :

Brother, thou art gone before us, and thy saintly soul is flown Where tears are wiped from every eye, and sorrow is unknown-8

misses a large part of the enjoyment incident to such verse itself, when considered amidst its proper circumstances, as a plant in its native soil

If the third drama, Belshazzar, is less fine in texture, and the melody, the pathos, are more of stage properties, and less evidently spontaneous, I attribute the decline mainly to the subject. The centre, the pivot, of the poem was necessarily the writing on the Palace-wall ; and with that the romance of the Jewish maiden, Benina, has no direct connexion. They move along different lines, which only 
casually intersect. Nothing could be more manifestly forced than the final grouping of the monarch, his mother, and the Hebrew family. When the Prophet deciphers the blazoned sentence, how glaring again the descent of the poem below the level of the Biblical narrative! Yet here too the authorship is internally capable of identification with that of the earlier dramas. The Jewish girl's soliloquy on the summit of the tower of Bel is full of melancholy harmony. Belshazzar's accomplishment of his pledge to the herald of his doom, is marked by a rare magnanimity :

Go-lead the Hebrew forth, array'd

In the proud robe, let all the city hail

The honour'd of Belshazzar. ${ }^{9}$

We hear the true royal ring both in that, and in the fallen monarch's farewell to empire and life.

Some element, I am conscious, is wanting to lift Milman's verse back to the rank which much in it still challenges. The whole glows, but like the sun in a mist. We miss the rays which should glance hither and thither; the spontaneous echoes from the minds of the readers, and from within the poetry itself. The writer's themes are in themselves exalted and noble. He was equipped by nature and education to develop their lofty qualities. Out of his materials he constructed, in two cases at least, beautiful edifices. Yet we are sensible throughout of a radical want. Here and there it is supplied, as in Margarita's moving entreaty to be suffered to precede Fabius in death; but in general we do not feel that to the skilful builder's art, and to a certain fiery appreciation of the qualities of the situation, the author was in the habit of adding something of his own soul. He does not, like the great singers, produce upon me at all events the impression of having passed the constituents of his poetry through his inner nature, and having set them in 
their places breathing of it. A perceptible monotony in his strains tells the same tale. He strikes a single key continually, though one of dignity and power.. A predestined poet may prefer a particular note; he will give signs that he has many at his disposal. With all their feebleness, The Hours of Idleness indicated more promise than the magnificent Lord of the Bright City. Nevertheless, it might have been anticipated that, whatever the shortcomings of Samor, at any rate the Siege of Jerusalem and the Martyr of Antioch would practically oblige their author to go on poetizing. The poetic void after them, unless for a few fine hymns, during two-thirds of a lifetime inflicts a shock as at a sudden darkness. I can only surmise a mental revolution analogous to that which the body undergoes in its successive modifications through age.

A similar spiritual change dried up, or sealed, the fountains of song in two other singers, a senior and a junior, far more subtle, and of wider compass, if not of a larger intelligence. Both, early in middle life, turned from construction to analysis. The critical faculty in Coleridge took the shape of theological metaphysics. In Matthew Arnold it was a rage for the clearance of rubbish ; for the business, to be understood in a highly complimentary sense, of a moral and literary dust-destructor. It became in Milman inquiry into the bases of ecclesiastical history. Throughout this second stage of his intellectual development he did good, even great, work. There was creation as well as demolition. He pulled down that he might build up. Yet some will regret with me, for the sake both of poetry, and of his fame; that the mortar of the foundations he renewed had to be mixed with the life-blood of possible fresh Sieges of Jerusalem and Martyrs of Antioch. As the fabric of Latin Christianity slowly rose, I used at Oxford to hear eternity 
predicted for it. I suspect it will be a phenomenon in the history of Histories if the fruits of imagination do not outlive those of research.

The Poetical Works of the Rev. H. H. Milman. Three vols. John Murray, 1839. (Also: The Fall of Jerusalem, 1825, New edition. The Martyr of Antioch, 1823, New edition. Belshazzar, 1822. John Murray.)

1 The Belvidere Apollo, vol. ii (1839 ed.).

${ }^{2}$ Samor, Lord of the Bright City, vol. ii (1839 ed.).

${ }^{3}$ The Fall of Jerusalem: A Dramatic Poem, pp. 7-8 (1825 ed.).

4 Ibid., pp. 64-5 (1825 ed.). ' Ibid., pp. 34-5 (1825 ed.).

- The Martyr of Antioch: A Dramatic Poem, pp. 146 and 149 (1823 ed.).

? Ibid., pp. 159-60 (1823 ed.). $\quad$ Ibid., pp. 33-5 (1823 ed.).

- Belshazzar: A Dramatic Poem, p. 123 (1822 ed.). 


\section{JOHN KEBLE}

\section{$1792-1866$}

Canon Ainger, an admirable critic, once commented to me on the claim of the writer of a popular hymn to respect as a poet: 'You know, the standard of poetic merit in hymns is not high.' Is it necessary to plead for saintly Keble's poetic title, as it were, in forma pauperis ? He wrote, indeed, other verse, some of it of worth; for example, a delightful appeal of wild flowers to the lord of the manor to spare from his high farming :

Shady spots and nooks, where we Yet may flourish, safe and free. ${ }^{1}$

But, as a whole, it is inconsiderable ; and by his hymns he must virtually be judged. Without going, therefore, outside The Christian Year and Lyra Innocentium, I am glad for my own sake to be able from them to answer my question in the negative. I find genuine poetic sensibility in a fair proportion of their contents. Tenderness, sympathy, judgement, and delicacy, aspirations after the noble and sublime, are there. Everywhere I observe a feeling for beauty, a sincere longing to understand and interpret Nature.

Every one has felt the sweetness of some five or six stanzas of the Evening Hymn in The Christian Year. Occasional Thoughts on children's troubles in the Lyra Innocentium almost match them. ${ }^{2}$ With equal intuition and affectionateness Keble draws happy lessons from sickness, the heart's self-doubtings, mourning, and death. At times, not 
often, he nears sublimity ; as when he imagines a revelation of the spot in the Garden of Gethsemane,

That felt Thee kneeling - touch'd Thy prostrate brow ; ${ }^{3}$

when he follows the spirit of the Crucified

At large among the dead ; 4

or, as by the Saviour's side, muses on the lone upland above the waters of Gennesaret.

$\mathrm{He}$ is nevertheless more at home where he habitually dwelt; that is, amid scenes of natural grace and beauty. They make for him fitting framework for every word of Prophet and Evangelist. He had sat at Wordsworth's feet, and learnt to register each

$$
\text { soft touch invisible, }{ }^{5}
$$

by which Nature, newly born at every successive sunrise, works her wonders. He could have written a monograph on

the soft green willow springing

Where the waters gently pass,

Every way her free arms flinging

0 'er the moist and reedy grass ; ${ }^{6}$

and volumes on the multitudinous flowers of the field :

Sweet nurslings of the vernal skies,

Bath'd in soft airs, and fed with dew;

What more than magic in you lies,

To fill the heart's fond view !

Relics ye are of Eden's bowers,

As pure, as fragrant, and as fair,

As when ye crown'd the sunshine hours

Of happy wanderers there. ${ }^{\text {? }}$

Mountains, in particular, he loved for their peculiar companionship, as he deemed, with Heaven :

Where is thy favour'd haunt, eternal Voice,

The region of Thy choice, 
Where, undisturb'd by sin and earth, the soul Owns Thy entire control ?-

'Tis on the mountain's summit dark and high, When storms are hurrying by ;

'Tis 'mid the strong foundations of the earth, Where torrents have their birth.

No sounds of worldly toil ascending there, Mar the full burst of prayer;

Lone Nature feels that she may freely breathe, And round us and beneath Are heard her sacred tones : the fitful sweep

Of winds across the steep,

Through wither'd bents-romantic note and clear,

Meet for a hermit's ear,-

The wheeling kite's wild solitary cry,

And, scarcely heard so high,

The dashing waters when the air is still

From many a torrent rill

That winds unseen beneath the shaggy fell,

Track'd by the blue mist well ;

Such sounds as make deep silence in the heart

For Thought to do her part. ${ }^{8}$

For him each day marshals a triumphal pageant, from dawn, with its every dewy spark jewelling leaf and blossom, to the glory of the clouds about the setting sun. To a certain extent-though, in general, it must be confessed, he does violence to his own sweet nature in dogmatizing to the young-he even consents to view the flush of springtide, the garlands of May, through a child's eyes. ${ }^{9}$

Now and then, for moments, he actually seems, though in a hymnal, to forget hymnology, and to be unconscious of all but Nature's and Music's magic :

'Tis misty all, both sight and sound-

I only know 'tis fair and sweet-

'Tis wandering on enchanted ground

With dizzy brow and tottering feet. ${ }^{10}$ 
Almost it might be a bard of Love who sang, if he had ended there :

Who ever saw the earliest rose

First open her sweet breast ?

Or, when the summer sun goes down,

The first soft star in evening's crown

Light up her gleaming crest ?

But there 's a sweeter flower than e'er

Blush'd on the rosy spray-

A brighter star, a richer bloom

Than e'er did western heaven illume

At close of summer day.

'Tis Love, the last blest gift of Heaven ;

Love, gentle, holy, pure ;

But tenderer than a dove's soft eye,

The searching sun, the open sky,

She never could endure."1

Having said so much in Keble's favour, can I stop short of pronouncing him not only a writer of poetry, but a poet inspired? I can, and must, though, in the opinion of many, I condemn myself as a critic. One quality of high poetry, though there are approaches towards it now and then, I do not discover in him; and, unfortunately, it happens to be of the essence. The defect is not that he is facile and diffuse; for that weakness he shares with some of the highest. It is not that his tendency, although he can be daintily simple, is to be artificial, ingenious, and elaborate. Greatness may be there too. The capital fault I find, sensible as I am of an apparent paradox, is that the piety, which is the one motive of his verse, is wanting in passion. Passion is a condition of all masterly achievement, probably in all literature, certainly in poetry. It burns beneath Dryden's Court politics, Swift's misanthropy, Burns's defiant humour, Byron's cynicism. Above 
all, for religious verse, such as Herbert's, Crashaw's, Vaughan's, Herrick's, it is the breath of life. In Keble's it is never more than an accident. He, the devoutest of men, the most emotional, the least worldly, a Nathaniel without guile, only by fits and starts blazes into flame from his own sovereign theme.

I feel him, while he diversifies and polishes his rhythm, drills his topics, verifies his allusions, corrects his punctuation, to be always on the watch against himself. $\mathrm{He}$ is guarding against explosions of enthusiasm, which would have swept away his excess of elaboration, and the prolixity fatal to many a fine thought. In modesty and shyness like to Herbert, Crashaw, Vaughan, he was, unlike them, not of those who invite or suffer the world to count their heart-beats. He has sung:

Well it is for us our God should feel

Alone our secret throbbings; so our prayer

May readier spring to Heaven, nor spend its zeal

On cloud-born idols of this lower air. ${ }^{12}$

The rule is true for worshippers; not for the poet who writes of them and himself. It is from those deep throbbings, secret except for verse, that essential poetry is distilled. Poetry demands the sacrifice of the privacy of souls. A poet, to aspire to the peaks, must be incapable of withholding the best and dearest in his nature. Keble, if so made as to have dared thus to suffer his spirit to take fire, at all events did not let it. Always he reserved something from the furnace. He constantly was pointing out how Christians, he with the rest, ought to think of Earth and Heaven, rather than how he himself in fact thought. Not having fastened his soul to the stake, he is not of the inner circle in poetry. Whether, had he submitted himself, he would have been, who can tell ? 
The Christian Year. Thoughts in Verse for the Sundays and Holidays throughout the Year. Forty-third ed. Oxford: John Henry Parker, 1853. Lyra Innocentium. Oxford: John Henry Parker, 1846. Miscellaneous Poems, by the Rev. John Keble. Oxford and London: James Parker \& Co., 1869.

1 Petition to the Lord of the Manor of Merdon of Anemone, Orchis, Violet, Daffodil, Cowslip, and Primula (Miscellaneous Poems), p. 281.

: A Sister, pp. 149-51, and Fire, pp. 155-7 (Lyra Innocentium, Children's Troubles).

${ }^{3}$ Monday Before Easter, st. 8 (Christian Year), p. 119.

- Easter Eve, st. 2 (ibid.), p. 137.

5 Morning, st. 1 (ibid.), p. 1.

- First Sunday After Epiphany, st. 4 (ibid.), p. 56.

? Fifteenth Sunday After Trinity, stanzas 1-2 (ibid.), p. 252.

${ }^{8}$ Twentieth Sunday After Trinity, stanzas 1-3 (ibid.), pp. 272-3.

- May Garlands (Lyra Innocentium, Children's Sports), pp. 169-71.

${ }^{10}$ Fourth Sunday in Advent, st. 5 (Christian Year), p. 23.

12 Fourth Sunday in Lent, stanzas 2, 4, 5 (ibid.), pp. 105-6.

${ }_{12}$ Twenty-fourth Sunday After Trinity, st. 3 (ibid.), p. 285. 


\section{JOHN HENRY NEWMAN}

\section{$1801-1890$}

OXFord logic and metaphysics, and English Church lethargy cost literature a great poet, and gained for it a great poem. Dr. Newman's earlier productions showed more of promise than performance. The first in the collection of 1868 is separated from The Dream of Gerontius, dated January, 1865, which closes the volume, by a space of forty years. Naturally the contents might be expected to differ widely in character. As naturally it might be supposed that the earlier would have more of fancy and enthusiasm. On the contrary, the writer is more selfrestrained, less manifestly full of original ideas, at the commencement of his poetical career than at its end. While as yet uncertain of his theological position, doubting his old views, alarmed by the fascinations of the new, he curbed his imagination. When he had found peace at last, if not Nirvana, satisfaction at the sense of finality burst into an amazing, an amazed ecstasy, which transmuted a lake of fire into a bed of roses.

Not that the hundred and forty-three poems which precede the Dream are without distinct charms of their own. They are devout, with a modesty and good taste which hymnology often lacks. Frequently their spirit rises so high that the reader of them feels a shock when suddenly it seems to droop and sink. Their fault is a repression, rather than an incapability, of passionateness; a determination to make poetry a property of religion, and not religion subject-matter of poetry. Compare them with 
the hymns in Milman's Martyr of Antioch or Siege of Jerusalem, and the contrast is violent. Poetry is a jealous mistress. Service it may lend; it will not endure to be treated as a handmaid. It insists upon choosing its times and seasons; upon enjoying whatever society it prefers. Self-abnegation, the bowing of its will to a predetermined object, are not among its virtues. On the requisition, even by a John Henry Newman, of sacrifices of its independence, it may continue the loan of form and rhythm ; inspiration ceases. The poetic instinct was always in the man, ready to operate, if allowed its liberty. He on his part was as resolved to keep its action subservient to an obligation he regarded as sovereign. Treated as a drudge the Muse turns sullen and mute. Thus the reader may have prepared for a poem as well as hymn, when fancy is seen to withdraw abruptly from the brink of a noble lyric. How easily, for example, might The Scars of Sin, Desolation, For the Dead, have been caressed into music !

Sometimes a thought is so fine that it is hard to explain the general neglect; as in Transfiguration:

I saw thee once, and nought discern'd For stranger to admire;

A serious aspect, but it burn'd With no unearthly fire.

Again I saw, and I confess'd

Thy speech was rare and high ;

But yet it vex'd my burden'd breast,

And scared, I knew not why.

I saw once more, and awe-struck gazed

On face, and form, and air ;

God's living glory round thee blazed-

A Saint-a Saint was there ! ${ }^{1}$

I doubt if many even of Newman's admirers know of his 
tender Birthday Offering on the grave of his young sister !

Loveliest, meekest, blithest, kindest !

Lead! we seck the home thou findest!

Though thy name to us most dear,

Go! we would not have thee here.

Lead, a guiding beacon bright

To travellers on the Eve of Light.

Welcome aye thy star before us,

Bring it grief or gladness o'er us ;-

Keen regret and tearful yearning,

Whiles unfelt, and whiles returning :-

Or more gracious thoughts abiding,

Fever-quelling, sorrow-chiding :-

Or, when day-light blessings fail

Transport fresh as spice-fraught gale,

Sparks from thee which oft have lighted

Weary heart and hope benighted.

I this monument would raise,

Distant from the public gaze.

Few will see it; few e'er knew thee ;

But their beating hearts pursue thee,-

And their eyes fond thoughts betoken,

Though thy name be seldom spoken.

Pass on, stranger, and despise it !

These will read, and these will prize it. ${ }^{2}$

The merits of such charming things have, I can but suppose, been smothered under the neighbouring pile of verse pressed into service as a vehicle of religious musings, often momentous, yet not poetry. In other cases the infusion of militant dogma may have denied popular acceptance to pieces otherwise fully entitled to it. Mark, for example, the light touch in the Month of Mary :

The green green grass, the glittering grove,

The heaven's majestic dome,

They image forth a tenderer bower,

A more refulgent home ; 
They tell us of that Paradise

Of everlasting rest,

And that high Tree, all flowers and fruit,

The sweetest, yet the best.

O Mary, pure and beautiful, Thou art the Queen of May ;

Our garlands wear about thy hair, And they will ne'er decay.

As bright, if more combative, is the Pilgrim Queen :

There sat a Lady all on the ground,

Rays of the morning circled her round.

Save thee and hail thee, Gracious and Fair,

In the chill twilight what wouldst thou there ?

'Here I sit desolate,' sweetly she said,

'Though I'm a queen, and my name is Marie ;

Robbers have rifled my garden and store,

Foes they have stolen my heir from my bower.

They said they could keep Him far better than I,

In a palace all His, planted deep and raised high.

'Twas a palace of ice, hard and cold as were they,

And when summer came, it all melted away.

Next would they barter Him, Him the Supreme,

For the spice of the desert, and gold of the stream ;

And me they bid wander in weeds and alone,

In this green merry land which once was my own.

A moment,' she said, ' and the dead shall revive;

The giants are failing, the Saints are alive;

$\mathrm{I}$ am coming to rescue my home and my reign,

And Peter and Philip are close in my train.' 4

And he had a gift for loftier strains, still controversial ; for instance, Refrigerium :

They are at rest ;

The fire has eaten out all blot and stain, And, convalescent, they enjoy a blest

Refreshment after pain;

Thus, to the End, in Eden's grots they lie,

And hear the fourfold river, as it hurries by. 


\section{They hear it sweep}

In distance down the dark and savage glen;

Safe from ite rocky bed, and current deep, And eddying pools, till then ;

They hear, and meekly muse, as fain to know

How long untired, unspent, that giant stream shall flow

And soothing sounds

Blend with the neighbouring waters as they glide;

Posted along the haunted garden's bounds

Angelic forms abide,

Echoing, as words of watch, o'er lawn and grove, The verses of that hymn which Seraphs chant above. ${ }^{5}$

Yet again ; and there is the immortal Pillar of the Cloudbetter known by its first three words-with which he might have been thought to reach his high-water mark as a poet. In hymnology, indeed, he never exceeded that sweet sad cry from heart to hearts for light to lead amid the gloom; for, as a hymn, it is unsurpassable. From the first line to the last, when

the night is gone,

And with the morn those angel faces smile

Which I have loved long since, and lost awhile- ${ }^{6}$

it might, unless for what was to follow, have been held to be as poetically lovely as verse can be without ceasing to be prayer.

But thirty years later he accomplished results in poetry which the Pillar of the Cloud itself cannot pretend to rival. Consider the absorption of passion into piety, the extortion of the consent of an intellect as searching as Voltaire's to an abjuration of all spiritual freedom, the renunciation of joy, pity, beauty. Watch the erection, on foundations thus remorselessly laid, of a pile of sublimest fancy. Then say how, when, and where literature has on like lines ever matched the Dream of Gerontius ! In it Newman conjures 
more deftly with the reason of his readers than the most dexterous Indian wonder-worker with the eyes of spectators. $\mathrm{He}$ arranges more dazzling combinations than the most ingenious pyrotechnist. He is a magician in his manipulation of thought and feeling. He makes us accept for natural what is most unreal, for fair what is ugly, for beneficent what is barbarous, for celestial what is earthy.

I can recall nothing in English literature to equal the dialectic skill with which probability, intelligibility, is breathed into the dying Saint's horror at the death he might be expected to welcome-horror lest the vice-laden body should sweep with itself the soul, though now purified, down the gulf of null chaos :

'Tis Death-O loving friends, your prayers! 'tis he !

As though my very being had given way,

As though I was no more a substance now, And could fall back on nought to be my stay,-

Help, loving Lord! Thou my sole Refuge, ThouAnd turn no whither, but must needs decay

And drop from out the universal frame Into that shapeless, scopeless, blank abyss, That utter nothingness, of which I came.

Sanctus fortis, Sanctus Deus,

De profundis oro te,

Miserere, Judex meus,

Mortis in discrimine. ${ }^{7}$

Speeding to the Judgement in the arms of his Guardian Angel, his Soul, but half disembodied, is conscious that it remains liable, though itself sinless now, for its mated Body's old impurities; that it cannot enter into the communion, for which it longs, with the perfection of God made Man, until the gross shadow upon it of its guilty flesh be purged away. But fear has ceased, and weariness, and pain : 
I went to sleep; and now I am refresh'd, A strange refreshment: for $I$ feel in me An inexpressive lightness, and a sense Of freedom, as I were at length myself. Am I alive or dead ? I am not dead, But in the body still ; for I possess

A sort of confidence, which clings to me, That each particular organ holds its place As heretofore, combining with the rest Into one symmetry, that wraps me round, And makes me man; and surely I could move,

Did I but will it, every part of me.

Or $I$ or it is rushing on the wings

Of light or lightning on an onward course,

And we e'en now are million miles apart.

Yet-is this peremptory severance

Wrought out in lengthening measurements of space,

Which grow and multiply by speed and time ?

Or am I traversing infinity

By endless subdivision, hurrying back

From finite towards infinitesimal,

Thus dying out of the expanded world ? 8

Throughout his journeying he hears voices; his convoying angel's :

Oh, what a heart-subduing melody!

Then, the sullen howl of demons outside the Judgement Court, swarming,

Hungry and wild, to claim their property, And gather souls for hell;

Then, the song of

tender beings angelical,

Least and most childlike of the sons of God ;

like the rushing of the wind-

The summer wind-among the lofty pines;

Swelling and dying, echoing round about,

Now here, now distant, wild and beautiful ;

While, scatter'd from the branches it has stirr'd,

Descend ecstatic odours ; 
with, all the time, but thin and low, and fainter and more faint, the accents :

the voice of friends around the bed, Who say the 'Subvenite' with the priest.?

Absolute rest, delight, emancipation; yet the whole thrilled with a longing for agony of pain; to be fitted by fire to abide hereafter in the Divine Presence-if but,

ere I plunged amid the avenging flame,

I had one sight of Him to strengthen me.

And in a moment, and for a moment, his wish granted -at the cost of lying before the Throne, scorched and shrivelled by

the keen sanctity,

Which, with its effluence, like a glory, clothes

And circles round the Crucified !

It is a gain of measureless content, so only that his ordeal be completed, as he prays, to the full :

Take me away, and in the lowest deep

There let me be,

And there in hope the lone night-watches keep,

Told out for me.

There motionless and happy in my pain,

Lone, not forlorn, -

There will I sing my sad perpetual strain,

Until the morn.

There will I sing, and soothe my stricken breast,

Which ne'er can cease

To throb, and pine, and languish, till possest

Of its Sole Peace.

There will I sing my absent Lord and Love :-

Take me away,

That sooner I may rise and go above,

And see Him in the truth of everlasting day. ${ }^{11}$

The whole high, strange argument, for its metaphysical 
dexterity and depth, is worthy of Lucretius holding a very different brief. But I am grateful especially for the grand dithyrambs, worthy also of the great Roman, which authorize an inscription on the roll of British poets of the illustrious name of John Henry Newman, as much to their honour in the companionship as to his !

Verses on Various Occasions (J. H. N.). London: Burns, Oates $\&$ Co., 1868.

1 Transfiguration, No. 51, p. 91.

${ }^{2}$ Epiphany Eve: A Birthday Offering, No. 14, pp. 41-2.

3 The Month of Mary, No. 150, pp. 259-60.

4 The Pilgrim Queen, No. 149, pp. 255-7.

5 Refrigerium, No. 111, pp. 184-5.

- The Pillar of the Cloud (Lead, Kindly Light), No. 81, June 16, 1833, pp. 133-4.

7 The Dream of Gerontius, January, 1865, No. 166, pp. 294 and 297.

8 Ibid., pp. 301-4.

10 Ibid., pp. 321 and 336.

- Ibid., pp. 304, 313, 323, 335.

11 Ibid., pp. 336-7. 


\section{'THOMAS HOOD}

\section{$1798-1845$}

ONE of the uncrowned kings ; the Heir bred, like Victor Hugo's L'Homme qui Rit, to suppose that he was a clown! If only he had known that his work in life was pure poetrythat he was a poet born! Till he died he never took rank as a poet. Scarcely would he have recognized himself as one. Although throughout his life he wrote poems, most of them received with favour, some with applause, they came as separate phenomena. His profession continued to be that of wit and humorist. The productions themselves, many as they were, did not muster together, and acclaim him for their chief and captain. Not until he had died, after forty-seven years of grinding care and poverty, were his graver poems, which in general reflect his adversities in their gloom, given to the world in a collected form. The utmost their editor hoped for them then was, that ' in any future recital of the names of writers who have contributed to the Stock of genuine English poetry, Thomas Hood might find honourable mention'.

The commendation is altogether too apologetic. It is pitched in a key too low to satisfy Hood's sincere admirers. Poets and poems are divisible into two primary classes. There are those that the kingdom of poetry; though it is willing to admit them, could do without, and those that it could not. Whatever his particular rank in the indispensable order, it is to this that he belongs. As I glance over the two volumes which comprise the body of his verse, serious and humorous, I am constantly lighting upon 
pieces which it would be impossible to omit without the creation of a painful, visible gap in literature.

The Song of the Shirt is in possession of a niche which could not otherwise be filled :

Oh! but to breathe the breath

Of the cowslip and primrose sweet-

With the sky above my head,

And the grass beneath my feet.

For only one short hour

To feel as I used to feel,

Before I knew the woes of want

And the walk that costs a meal!

Oh! but for one short hour !

A respite however brief!

No blessed leisure for Love or Hope,

But only time for Grief !

A little weeping would ease my heart,

But in their briny bed

My tears must stop, for every drop

Hinders needle and thread ! 1

A second would stand painfully empty without the Dream of Eugene Aram to occupy it, and the abrupt shuddering close :

That very night, while gentle sleep

The urchin eye-lids kiss'd,

Two stern-faced men set out from Lynn,

Through the cold and heavy mist;

And Eugene Aram walk'd between,

With gyves upon his wrist. ${ }^{2}$

Yet another place he has permanently appropriated by his haunting Haunted House-murder-haunted-with its rusty stains,

Obscurely spotted to the door, and thence With mazy doubles to the grated casement-

Oh what a tale they told of fear intense,

Of horror and amazement ! 


\section{THOMAS HOOD}

What human creature in the dead of night

Had coursed like hunted hare that cruel distance?

Had sought the door, the window, in his flight,

Striving for dear existence ? ${ }^{3}$

I do not claim on his behalf a monopoly of capacity for measuring against one another the powers of Earth and Hell ; but I know of none but Burns who equals him in the reconciliation, for the purpose, of the tragic and the comic. Mark the trooping of monsters to avenge the attack of the Brocken forgemen upon Hell's lord:

Awful coveys of terrible things,

With forked tongues and venomous stings,

On hagweed, broomsticks, and leathern wings

Are hovering round the Hut !

Shapes, that within the focus bright

Of the Forge, are like shadows and blots;

But, farther off, in the shades of night, Clothed with their own phosphoric light,

Are seen in the darkest spots.

Sounds! that fill the air with noises,

Strange and indescribable voices,

From Hags, in a diabolical clatter-

Cats that spit curses, and apes that chatter

Scraps of cabalistical matter-

Owls that screech, and dogs that yell-

Skeleton hounds that will never be fatter-

All the domestic tribes of Hell,

Shrieking for flesh to tear and tatter,

Bones to shatter,

And limbs to scatter,

And who it is that must furnish the latter

Those blue-looking men know well ! 4

As I know of few things in poetry more grotesquely terrible than the burning of Satan to a cinder, so I feel the singularity of Hood's gift for eliciting the poetry of everyday life. How dainty is the pathos employed on so commonplace a topic as a common death-bed !

vOL. II 
We wateh'd her breathing thro' the night, Her breathing soft and low,

As in her breast the wave of life Kept heaving to and fro.

So silently we seem'd to speak, So slowly moved about, As we had lent her half our powers

To eke her living out.

Our very hopes belied our fears, Our fears our hopes beliedWe thought her dying when she slept, And sleeping when she died.

For when the morn came dim and sad, And chill with carly showers, Her quiet eyelids elosed-she had Another morn than ours. ${ }^{5}$

Perfect every line. We owe more gratitude for this investiture of simple death-such as it is not beyond the least of us to aspire to-with a quiet beauty, than for a song of triumph over a Conqueror's bier. That indeed is among Hood's merits, which he shares with the princes of song, that, though he can rise to the heights, he sees the beauty of plain things. A child's embrace of its mother is as ordinary as dying; and see how much it too suggests to him !

Love thy mother, little one !

Kiss and clasp her neck again ;-

Hereafter she may have a son

Will kiss and clasp her neck in vain.

Love thy mother, little one

Gaze upon her living eyes, And mirror back her love for thee ;Hereafter thou may'st shudder sighs To meet them when they cannot see.

Gaze upon her living eyes! 
Press her lips the while they glow

With love that they have often told ; -

Hereafter thou may'st press in woe,

And kiss them till thine own are cold.

Press her lips the while they glow ! ${ }^{6}$

Really there is nothing, it might be thought, in his recollections of his boyhood, with which it was worth troubling the world; perhaps, even himself ; and yet the sweetness for us all !

I remember, I remember,

The house where I was born,

The little window where the sun

Came peeping in at morn;

He never came a wink too soon,

Nor brought too long a day,

But now, I often wish the night

Had borne my breath away!

I remember, I remember,

The roses, red and white,

Ihe violets, and the lily-cups,

Those flowers made of light !

The lilacs where the robin built,

And where my brother set

The laburnum on his birthday,-

The tree is living yet !

I remember, I remember,

Where I was used to swing,

And thought the air must rush as fresh

To swallows on the wing ;

My spirit flew in feathers then,

That is so heavy now,

And summer pools could hardly cool

The fever on my brow !

I remember, I remember,

The fir-trees dark and high;

I used to think their slender tops

Were close against the sky; 
It was a childish ignorance,

But now 'tis little joy

To know I'm farther off from heav'n

Than when I was a boy. ${ }^{7}$

Already I have instanced enough admirable verse to make a reputation; and how much $I$ have omitted ! But, at all events, I must not pass by Ruth, as she stands

breast high amid the corn, Clasp'd by the golden light of morn, Like the sweetheart of the sun, Who many a glowing kiss had won ${ }^{8}$

or fair Ines, who has
gone into the West,
To dazzle when the sun is down,
And rob the world of rest;
She took our daylight with her,
The smiles that we love best,
With morning blushes on her cheek
And pearls upon her breast; ${ }^{9}$

or the all-sufficient love-song :

I love thee-I love thee !

'Tis all that I can say:

It is my vision in the night, My dreaming in the day: The very echo of my heart, The blessing when I pray:

I love thee-I love thee !

Is all that I can say. ${ }^{10}$

Everywhere still, throughout the two sister volumes, the reader is sure to come upon lines, phrases, which will not consent to be forgotten. Even in that ugliest of poems with greatness in them, The Last Man, which fascinates without delighting, there is a redeeming spark of pathosthe confession of loneliness by the survivor of human kind, 
a hangman, who, to be sole heir of the earth, had just strung up his solitary companion, a beggar man :

If the veriest cur would lick my hand,

I could love it like a child ! 11

So, again, the humour of the tale of Miss Kilmansegg leaves space for a grim individual pitifulness :

Gold, still gold ! hard, yellow, and cold-

For gold she had lived, and she died for gold ! ${ }^{12}$

At any instant a figure suddenly will start forth, with an appeal to the heart, at once entirely natural and entirely original ; the outcast, on the river bank, in glaring London, with its clothed, fed, and sheltered millions, as

She stood 'with amazement', Homeless by night ; 13

the swarm waiting for the Casual Ward to open; sempstress, artisan, whole families ;

Father, mother, and 'careful child',

Looking as if it had never smiled; ${ }^{\text {H }}$

Iyycus, the centaur that had been man, when the unsuspecting boy insults his shame at his bestial shape with a handful of grass, and in anger at its rejection, pelts him with stones :

I felt not, whose fate

Was to meet more distress in his love than his hate $;{ }^{15}$

the fisherman in his storm-tost boat on the lee-shore :

Oh, God ! to think Man ever

Comes too near his Home !

and the hard-tried poet himself, with his birthday-wish for his daughter, of

all the bliss that life endears,

Not without smiles, ' nor yet from tears'

Too strictly kept. ${ }^{16}$ 
None has ever more entirely possessed the secret of sudden ascents ; sudden heart-kindlings. In some sort all the Serious Poems are examples; but we never can tell when Hood may not move to tears in a piece where the moment before he had been jesting :

There is no music in the life

That sounds with idiot laughter solely ;

There 's not a string attuned to mirth,

But has its chord in Melancholy. ${ }^{17}$

Doubtless, in compensation, after the manner of poets, with rare exceptions, such as Keats and Gray, he sinks now and again ; is eccentric without being original, tedious without being solemn. He can wear a sentiment threadbare, as in The Lady's Dream, and The Lay of the Labourer. His endless fancies can cloy, though in such a garden of delicate devices as The Plea of the Midsummer Fairies. He can be, though very seldom, merely dull, as in The Two Peacocks of Bedfont. He can smother Hellenic roses, as in Hero and Leander, in a thicket, however fragrant, of mediaeval embellishments. He can call a pamphlet an Ode, as his epistle to Rae Wilson, and spoil a charming sonnet with a poor pun. But measure the good against the ill; and the failures are nowhere. As a boy I heard nothing of Hood as a poet, much of him as a humorist. The Song of the Shirt surprised my little world without persuading it that it had to worship a poet the more. During my undergraduate days I first learnt to appreciate his poetry; and I have read and admired it ever since. Not the less, when recently I surveyed it as a whole, I stood amazed. The melody, the tenderness, and sympathy, the fancy, I find inexhaustible. Above all, is the unexpectedness. When I have believed I had explored all the singer's 
resources, he has touched a fresh cell in brain or heart, and music, echoing from the far distance, has set it thrilling.

I can conjecture no explanation of Hood's absence from the first class of British poetry, unless that he himself never clearly made up his mind to demand entrance. He preferred to hover outside, and sing as he listed. I do not dare to pretend to overrule his choice for himself, accepted, as apparently it has been, by the common arbiters of public opinion. In any case, whatever the view of his own place, it is impossible to question that of a numerous chorus of bright creatures of his imagination.

Poems (Serious), by Thomas Hood. Fourth edition. E. Moxon, 1851 . Poems of Wit and Humour, by Thomas Hood. Fifth edition. E. Moxon, 1853.

1 The Song of the Shirt (Serious Poems), stanzas 9-10, pp. 47-8.

2 The Dream of Eugene Aram, st. 36 (ibid.), p. 8.

${ }^{3}$ The Haunted House, Part III, stanzas 27-8 (Serious Poems), p. 39.

- The Forge: A Romance of the Iron Age, Part II, stanzas 12-13 (Poems of Wit and Humour), pp. 76-7.

- The Death-bed (Serious Poems), p. 180.

- To a Child, Embracing His Mother, stanzas 1-3 (Serious Poems), p. 184.

' I Remember, I Remember (Serious Poems), pp. 359-60.

${ }^{8}$ Ruth, st. 1 (Serious Poems), p. 354.

- Fair Ines, st. 1 (Serious Poems), p. 385.

10 To - , st. 1 (Serious Poems), p. 195.

${ }^{11}$ The Last Man, st. 35 (Poems of Wit and Humour), p. 95.

${ }_{12}$ Miss Kilmansegg and Her Precious Leg-Her Death, st. 16 (Serious Poems), p. 176.

${ }_{13}$ The Bridge of Sighs, st. 11 (Serious Poems), p. 43.

${ }^{14}$ The Workhouse Clock: An Allegory (Serious Poems), p. 54.

${ }_{15}$ Lycus the Centaur (Serious Poems), p. 319.

${ }_{16}$ To my Daughter on her Birthday, st. 3, p. 183.

17 Ode to Melancholy (Serious Poems), p. 379. 


\section{ELIZABETH BARRETT BROWNING}

\section{$1809-1861$}

OF the kind the foremost writer of English poetry-but a poetess. Or shall $I$, changing one word, say-and a poetess? For, with beauty everywhere, and womanliness as ubiquitous, I do not presume to decide on the independence, one of the other. Women-writers now and then, like George Sand and George Eliot, if not Currer Bell, have dissembled their sex. Either they have disdained allowances for it; or they have distrusted the superiority of the other to prejudice. Mrs. Browning had none of that affectation, or apprehension. On the contrary, she may be said to have gloried in being a woman.

In any case her verse would have proclaimed the fact. None but a woman-or perhaps a woman immured for a large part of her life in two rooms-could have imagined the repulse of a lover beloved, as in Insufficiency, ${ }^{1}$ and the martyr's cry of Denial !-

I love thee not, I dare not love thee ! go

In silence; drop my hand.

If thou seek roses, seek them where they blow

In garden-alleys, not in desert-sand.

Can life and death agree,

That thou shouldst stoop thy song to my complaint ?

I cannot love thee. If the word is faint,

Look in my face and see. ${ }^{2}$

The splendid unreason of Duchess May, the self-devotion to death of the Crusader's bride-page, and the sweet absurdities, not to be read by any male person without a blush, of 
Lady Geraldine, are all feminine. So is the conflict, with its result, between the egotism of Isobel's maternal love, and her sick child's craving for his home with the Angels. The grief of the dead blind boy's mother, that she can be no more his sun and moon, and his slave, betrays the same authorship. Pathos, a common gift of poets, is for her steeped in her femininity. Into the dumb affection of her dog this reads the instinct, the impulse, to share his mistress's distress, without requiring to comprehend or justify it :

And if one or two quick tears

Dropped upon his glossy ears, Or a sigh came double,

Up he sprang in eager haste,

Fawning, fondling, breathing fast,

In a tender trouble. ${ }^{3}$

In Wine of Cyprus, noblest, to me, of all her verse, I feel it equally in the affectionate endeavour to balance, as it were, by her own wasting sickness the earlier and different calamity of her aged tutor in Greek. Fondly, as she thanks him for his gift of Hellenic wine, she recalls their studies together in Attic tragedy:

And I think of those long mornings

Which my thought goes far to seek

When, betwixt the folio's turnings,

Solemn flowed the rhythmic Greek :

Past the pane the mountain spreading,

Swept the sheep's bell's tinkling noise,

While a girlish voice was reading,

Somewhat low for ais and ois.

Then, what golden hours were for us !

While we sate together there,

How the white vests of the chorus

Seemed to wave up a live air! 
How the cothurns trod majestic

Down the deep iambic lines

And the rolling anapaestic

Curled like vapour over shrines !

Oh, our Aeschylus, the thunderous,

How he drove the bolted breath

Through the cloud, to wedge it ponderous

In the gnarlèd oak beneath !

Oh, our Sophocles, the royal,

Who was born to monarch's place, And who made the whole world loyal,

Less by kingly power than grace !

Our Euripides, the human,

With his droppings of warm tears,

And his touches of things common,

Till they rose to touch the spheres!

Our Theocritus, our Bion,

And our Pindar's shining goals !-

These were cup-bearers undying,

Of the wine that's meant for souls.

And my Plato, the divine one,

If men know the gods aright

By their motions as they shine on

With a glorious trail of light !

And your noble Christian bishops,

Who mouthed grandly the last Greek !

Though the sponges on their hyssops

Were distent with wine-too weak.

For the rest-a mystic moaning

Kept Cassandra at the gate,

With wild eyes the vision shone in,

And wide nostrils scenting fate.

And Prometheus, bound in passion

By brute Force to the blind stone,

Showed us looks of invocation

Turned to ocean and the sun. 
And Medea we saw burning

At her nature's planted stake ;

And proud Oedipus fate-scorning

While the cloud came on to break-

While the cloud came on slow, slower,

Till he stood discrowned, resigned :-

But the reader's voice dropped lower

When the poet called him Blind.-

And now-were they not equals in fate? Alas!

For me, I am not worthy

After gods and Greeks to drink

And my lips are pale and earthy

To go bathing from this brink :

Since you heard them speak the last time,

They have faded from their blooms,

And the laughter of my pastime

Has learnt silence at the tombs. ${ }^{4}$

On account of sex-in spite of it-without relation to it-whichever you will-her work captivates. Its defects are many. The exuberance of words is exasperating. The Lost Bower, for example, delights for a dozen stanzas, and distresses long before the seventy-fourth. The habit of hunting for an occasion of tenderness everywhere is apt to degenerate into spurious sentimentality. The Poet's Vow, and A Child Asleep are flagrant offenders. Poetry has no more business with specific 'poetic' feeling than with 'poetic' diction. A dearth of common sense, and of what I am afraid I must call manliness, is uncomfortably discernible. But, on the other side, the merits are extraordinary. It was an angelic thought to imagine a nightingale in Paradise pursuing the human exiles thence with a regretful adieu :

I am the nearest nightingale

That singeth in Eden after you ; 
And I am singing loud and true, And sweet,-I do not fail.

I sit upon a cypress bough

Close to the gate, and I fling my song

Over the gate and through the mail

Of the warden angels marshalled strong,

Over the gate and after you !

And the warden angels let it pass, Because the poor brown bird, alas,

Sings in the garden, sweet and true. And I built my song of high pure notes, Note after note, height over height Till I strike the arch of the Infinite, And I bridge abysmal agonies

With strong, clear calms of harmonies,And something abides, and something floats, In the song which I sing after you.

Fare ye well, farewell ! ${ }^{5}$

\section{Hardly less ethereal is a Portrait :}

I will paint her as I see her,

Ten times have the lilies blown,

Since she looked upon the sun.

And her face is lily-clear,

Lily-shaped, and dropped in duty

To the law of its own beauty.

Oval cheeks encoloured faintly,

Which a trail of golden hair

Keeps from fading off to air ;

And a forehead fair and saintly,

Which two blue eyes undershine,

Like meek prayers before a shrine.

Face and figure of a child,-

Thought too calm, you think, and tender,

For the childhood you would lend her

Yet child-simple, undefiled,

Frank, obedient, waiting still

On the turnings of your will. 
And if any poet knew her,

He would sing of her with falls

Used in lovely madrigals.

And if any painter drew her,

He would paint her unaware

With a halo round the hair. ${ }^{6}$

For her, in requital of her pity, flowers from the grave of Cowper a recantation of his despair :

Like a sick ehild that knoweth not his mother while she blesses And drops upon his burning brow the coolness of her kisses,That turns his fevered eyes around-'My mother! where's my mother!'-

As if such tender words and deeds could come from any other ! The fever gone, with leaps of heart he sees her bending o'er him, Her face all pale from watchful love, the unweary love she bore him ! Thus woke the poet from the dream his life's long fever gave him, Beneath those deep pathetic Eyes which elosed in death to save him.?

Happily the light of the tomb was not needed to teach herself that joy may be neighbour to affliction :

I thought once how Theocritus had sung

Of the sweet years, the dear and wished-for years,

Who each one in a gracious hand appears

To bear a gift for mortals, old or young :

And as I mused it in his antique tongue,

I saw in gradual vision through my tears,

The sweet sad years, the melancholy years,

Those of my own life, who by turns had flung

A shadow across me. Straightway I was 'ware,

So weeping, how a mystic Shape did move

Behind me, and drew me backward by the hair :

And a voice said in mastery, while I strove,-

'Guess now who holds thee ?' 'Death', I said. But, there, The silver answer rang,-_ ' Not Death, but Love.' 8

If she ever wearied of life, it was rest to the body that she craved, not to the soul : 
Friends, dear friends, when it shall be That this low breath is gone from me, And round my bier ye come to weep, Let One, most loving of you all, Say, 'Not a tear must o'er her fall !

"He giveth His belovëd sleep !", 9

Not, after all, that repose and acquiescence of any sort were the special qualities of her predilection. On the contrary, her favourite mental attitude is one of something she feigns to be wrath and bitterness. She is incensed with her fatherland for its treatment of the Captive Napoleon, who,

trusting to his noblest foes, When earth was all too grey for chivalry, Died of their mercies 'mid the desert sea; ${ }^{10}$

with the world for its acceptance of the lying phrase, 'Loved Once,' as a truth :

Love strikes but one hour-Love! Those never loved Who dream that they loved Once ; ${ }^{11}$

with the mad folly, as well as guilt, of sinners of her own sex, in expecting from their partners in evil-commonly tempters-the least fidelity to the love they have tainted. 'Go!' she cries to the poor wretch she is confessing :

'Thou hast chosen the Human, and left the Divine !

Then, at least, have the Human shared with thee their wild berrywine?

Have they loved back thy love, and when strangers approached thee with blame,

Have they covered thy fault with their kisses, and loved thee the same?'

But she shrunk and said,

' God over my head

Must sweep in the wrath of His judgment-seas,

If He shall deal with me sinning, but only indeed the same

And no gentler than these.' ${ }^{12}$ 
Poetry would not be the admirable thing it is, were it not in its essence different from all else. Masters of the art, in general, while recognizing this, mix, like Assayers of the Mint, a goodly proportion of rougher and more ordinary metal with their poetic bullion. A minority, like Shelley and Keats, compact their edifices out of sunbeams, and rainbows, and driving mists. Mrs. Browning followed their example, and is nothing if not poetical. If the impression her heroes and heroines produce is often distasteful, it is that she endeavoured to lodge beings of solid flesh and blood in her unsubstantial structures. Shelley and Keats created inhabitants to occupy, without overcrowding, the tenements. Should an explanation of that radical error which led to her failures as contrasted with their successes be required, I am compelled to refer it to the simple facts, that she was a woman, and a recluse who had spent most of her life in the clouds. She imagined that she could lodge her corporeal creatures in them as conveniently. In Aurora Leigh, which has always, I confess, left a taste, as of soot, on my mental palate, all her womanly mistakes are accumulated and exaggerated. The circumstances, there especially, were too many, too modern, and too actual. But when elsewhere she indulges in analogous, though less trying, experiments, the effect is to me similarly unpleasant.

Fortunately the characters and incidents frequently are as airy as the habitations provided for them. The effect then is delightful. In its highest form her verse positively sings. How it lifts the heart in Wine of Cyprus, rocks to rest in Sleep and Cowper's Grave, sets on fire in Confessions, gathers a whole nosegay of love in Sonnets from the Portuguese, illuminates Parnassus in A Vision of Poets, and heralded a risen Italy when Austria was sealing 


\section{THE POETS}

her tomb! An aerial concert; and not the less exquisite for readers with a taste for such strains that, having no basis of common, companionable earth, they are as little likely to win, or keep, the popular ear as when, an undergraduate of Oxford, I heard one destined to rule it rouse the Union to frantic applause by jeering at the loveliest of the lovely whole.

Poems by Elizabeth Barrett Browning. Three vols. Chapman and Hall, 1864.

${ }^{1}$ Insufficiency, vol. iii, p. 187.

2 A Denial, st. 2, vol. iii, p. 179.

3 To Flush, my Dog, st. 2, vol. ii, p. 233.

- Wine of Cyprus, stanzas 9, 10, 11, 12, 13, 14, 15, 4, vol. iii, pp. 25-30.

5 A Drama of Exile, vol. i, p. 16.

6 A Portrait, stanzas 1-6 and 13-14, vol. iii, pp. 57-9.

7 Cowper's Grave, stanzas 9-10, vol. iii, p. 119.

${ }^{8}$ Sonnets from the Portuguese, Sonnet i, vol. iii, p. 188.

- The Sleep, st. 9, vol. iii, p. 113.

${ }^{10}$ Crowned and Buried, st. 13, vol. ii, p. 224.

11 Loved Once, st. 8, vol. iii, p. 68.

${ }_{12}$ Confessions, st. 9, vol. iii, pp. 64-5. 


\section{CHARLES KINGSLEY}

\section{$1819-1875$}

ANother example, among many, of the conflict for existence of faculties fitted for analogous pursuits. Nature equipped Charles Kingsley with the raw material, in varying proportions, of the forces which make a poet, a novelist, a social reformer, a student of science, a theologian, a historian. From the first they competed for possession of him. With the powerful aid of youth poetry seized on the leadership. Later on, with its own consent, monarchy was abolished. A commonwealth, in which each did what seemed good in its own eyes, took its place. The man being such as he was, and his poetical gift what it was, I do not suppose that literature, even poetry itself, has lost greatly by the revolution. His character was that of a combatant. He had a certain number of songs in him to sing; so many arrows of verse in his quiver. Forth he shot, hitting the mark now and again. When the archer found his quiver empty, he drew sword or dagger-romance, essay, lecture, sermon-and battled as manfully as ever. I see no ground for belief that, like some, he ceased versifying by compulsion of a more masterful passion of his soul, or out of indolence, satiety, or incapacity, mental or moral. Simply the one special weapon had done its work; and he exchanged it for another. I am grateful in the circumstances for the fact. He does not call up in me an idea of incalculable possibilities of poetical inspiration. It is well that he should not have deluded himself into imagining descents of the spirit when there were none. 
The outset of his poetical career was at once disappointing and promising. His Saint's Tragedy is strong in the wrong places. I myself am sensible of anger rather than sympathy. I keep wondering how much more of passionate reasonableness Robert Browning, for instance, might not have instilled into the hapless slave of her own and her teacher's fanaticism. It is a failure, if a brilliant one. Such too, I must, on the same ground of a neglect of proportion, judge Andromeda to be. The picture of the girl, when her mother leaves her on the rock-as no mother conceivably could have left a child-makes the heart ache, as the poet intended it should :

Watching the pulse of the oars die down, as her own died with them, Tearless, dumb with amaze she stood, ... .

helpless and hopeless, Wide-eyed, downward gazing in vain at the black blank darkness. ${ }^{1}$ But she almost disappears in an assemblage of fine scenes described in rolling, musical hexameters. The background is too engrossing for the action and the characters. The accessories, dawn-lit highlands, gambolling sea-nymphs, the charms of the golden-haired, ivory-limbed Deliverer, Athene's gracious wisdom, are fully and melodiously set forth; only the fateful combat itself, with the rescue, is dismissed in three casual lines. As an osprey on a dolphin; Thus fell the boy on the beast ; thus rolled up the beast in his horror, Once, as the dead eyes glared into his; then his sides, deathsharpened,

Stiffened and stood, brown rock, in the wash of the wandering water. ${ }^{2}$

Neither of the two works was the fruit of raw youth. They are their author's only poems of length; and neither has life in it. At the same time each has abundance of thought and fancy ; and each gives token of something better. 
In due time the promise was fulfilled by a succession of short poems ; many of them superior to the longer. They are superior, in that, while being things of beauty, as those were things of beauty, if inanimate, these are of a beauty which breathes and moves. Thus in Margaret's cry to Dolcino, we seem to feel the pulsation of mingled pride and suffering :

Ask if I love thee ? Oh, smiles cannot tell

Plainer what tears are now showing too well.

Had I not loved thee, my sky had been clear;

Had I not loved thee, I had not been here,

Weeping by thee.

Ask if I love thee ? How else could I borrow

Pride from man's slander, and strength from my sorrow ?

Laugh when they sneer at the fanatic's bride,

Knowing no bliss, save to toil and abide

Weeping by thee $!^{3}$

\section{A living well, if of bitterness, overflows in the complaint of the Ugly Princess :-}

My parents bow, and lead them forth,

For all the crowd to see-

Ah well ! the people might not care

To cheer a dwarf like me.

They little know how I could love,

How I could plan and toil,

To swell those drudges' scanty gains,

Their mites of rye and oil.

They little know what dreams have been

My playmates, night and day ;

Of equal kindness, helpful care,

A mother's perfect sway.

Now earth to earth in convent walls,

To earth in churchyard sod ;

I was not good enough for man

And so am given to God. ${ }^{4}$ 
Kingsley's readers are never without a consciousness of a call to arms ; of the stir of a stormy emotion which has set imagination at work. It vibrates in the Outlaw's defiance of laws forbidding him to

\section{hunt God's cattle upon God's ain hills ;}

in his contempt for the certainty of a noose in the end; and in his prayer to his mother to steal his body from the gibbet :

And when I am taen and hangit, mither, a brittling o' my deer, Ye'll no leave your bairn to the corbie craws, to dangle in the air ; But ye'll send up my twa douce brethren, and ye'll steal me frae the tree,

And bury me up on the brown brown muirs, where I aye looed to be. ${ }^{5}$

It inspired A Christmas Carol, with its gleams and shadows alike :

I went sighing past the Church across the moorland dreary' $O \mathrm{~h}$ ! never sin and want and woe this earth will leave, And the bells but mock the wailing round, they sing so cheery.' Then arose a joyous clamour from the wild fowl on the mere, Beneath the stars, across the snow, like clear bells ringing, And a voice within cried-' Listen! Christmas carols even here! Though thou be dumb, yet o'er their work the stars and snows are singing.' 6

Even the despair of Airly Beacon has a fresh movement as of hill-top air about it :

Airly Beacon, Airly Beacon;

Oh the pleasant sight to see

Shires and towns from Airly Beacon,

While my love climbed up to me !

Airly Beacon, Airly Beacon;

Oh the happy hours we lay

Deep in fern on Airly Beacon,

Courting through the summer's day ! 


\section{Airly Beacon, Airly Beacon;}

Oh the weary haunt for me,

All alone on Airly Beacon,

With his baby on my knee !?

I must add, though of a gusty freedom too rebellious against law and order to be acknowledged later on by a Church dignitary, the tale of the Swan-neck's recognitionhopeless even for a mother-of the body of King Harold, stripped, and gashed, and featureless :

Up and spake the Swan-neck high,

'Go! to all your thanes let cry

How I loved him best of all,

I whom men his leman call ;

Better knew his body fair

'Than the mother which him bare.'

Rousing erne and sallow glede,

Rousing grey wolf off his feed, Over franklin, earl, and thane, Heaps of mother-naken slain, . Round the red field tracing slow, Stooped that Swan-neck white as snow ;

Never blushed nor turned away,

Till she found him where he lay;

Clipt him in her armès fair,

Wrapt him in her yellow hair,

Bore him from the battle-stead,

Saw him laid in pall of lead,

Took her to a minster high,

For Earl Harold's soul to cry. ${ }^{8}$

The merit itself of these delightful pieces, and of others their equals, or all but equals, is of a kind to suggest that the writer had reached the limits of his powers. He might have been expected to produce more of corresponding, but scarcely higher, rank. A phenomenon, as in certain other poetical careers, is that from the same pen, within brief, if any positive, intervals, we find issuing three pieces, ideal, 
perfect. Except for the varieties of sadness, or suffering, they are wholly different; yet each is complete, consummate.

Read, a hundred times, The Sands of Dee; and there is never a sense of triteness. The whole is one long-drawn musical, not sob, but sigh :

' $O$ Mary, go and call the cattle home,

And call the cattle home,

And call the cattle home

Across the Sands of Dee.'

The western wind was wild and dank with foam,

And all alone went she.

The western tide crept up along the sand,

And o'er and o'er the sand

And round and round the sand,

As far as eye could see.

The rolling mist came down and hid the land;

And never home came she.

' $\mathrm{Oh}$ ! is it weed, or fish, or floating hair-

A tress of golden hair,

A drownèd maiden's hair

Above the nets at sea?

Was never salmon yet that shone so fair

Among the stakes on Dee.'

They rowed her in across the rolling foam,

The cruel crawling foam,

The cruel hungry foam,

To her grave beside the sea ;

But still the boatmen hear her call the cattle home

Across the Sands of Dee. ${ }^{9}$

I cannot pretend that the second, The Three Fishers, vies with that in absolute beauty. It does not carry about it the same atmosphere, the same sensation of gazing over a sea at sunset with undefined possibilities of the emergence of shadowy ships, from the unknown on to the far horizon. The outlines are clear cut. The 
sorrowfulness itself is natural and limited. It is all in life's hard bargain :

For men must work, and women must weep, And the sooner it's over, the sooner to sleep; And good-bye to the bar and its moaning. ${ }^{10}$

But the prospect beyond-if hard that too and gray, what strangeness, what infinitude, in its ordinance of the accept. ance by men of lines as they are laid for them ; of resignation to what might seem to be despair ; of tribulation's certainty of cessation-if not repose-in death! The song moves within narrow bounds but beats them all ; and it looks out upon a wide landscape beyond. And the melody besides !

Then for Santa Maura; the least popularly known of the trio; and the loftiest. Spiritual chemistry has turned a woman's love, a woman's trust, into a service of angelic adoration, which offends neither as extravagant, nor as profane. We shall search in vain the Dictionary of Christian Biography for the agonies and heroism of this three-months' bride of the blinded, tortured evangelist. Only by the poet's fancy have they been witnessed, and are here faithfully recorded in letters of blood and fire. The beauteous victim had been tempted, and half consented, to buy at the cost of the acknowledgement of an Emperor's divinity, and a sprinkling of incense upon Diocletian's altar, freedom for her husband-freedom in unknown lands to preach and pray :

Bend, save whole nations! would not that atone For one short word?

He had scornfully thrown back in her face such life and liberty; and remorsefully seeing her sin, she had bidden the Proconsul to do his worst.

Stripped and scourged, she ejaculates, in horror and shame at the recollection, to her husband : 
And yet no earthquake came to swallow me ; While all the court around, and walls, and roofs, And all the earth and air were full of eyes, Eyes, eyes, which scorched my limbs like burning flame, Until my brain seemed bursting from my brow; And yet no earthquake came! And then I knew This body was not yours alone, but God'sHis loan-He needed it; and after that The worst was come, and any torture more A change-a lightening -

even crucifixion itself-for that was by her bridegroom's side :

$$
\text { I crawled to you, }
$$

And kissed your bleeding feet, and called aloudYou heard me! You know all! I am at peace. Peace, peace, as still and bright as is the moon Upon your limbs, came on me at your smile, And kept me happy, when they dragged me back From that last kiss, and spread me on the cross, And bound my wrists and ancles-do not sigh ;

I prayed and bore it; and since they raised me up, My eyes have never left your face, my own, my own, Nor will, till death comes !

Her one desire, her prayer to God, is, that strength may be spared the gibbeted preacher to cry from the very cross :

Words which may wake the dead!

In ages to come, she predicts, they would know his worth :

And crown him martyr ; and his name will ring Through all the shores of earth, and all the stars, Whose eyes are sparkling through their tears to see His triumph-Preacher ! Martyr !-Ah-and me ?

If they must couple my poor name with his, Let them tell all the truth-say how I loved him, And tried to damn him by that love! Oh Lord ! Returning good for evil! and was this The payment I deserved for such a sin ? To hang here on my cross, and look at him Until we kneel before Thy throne in heaven ! ${ }^{11}$ 
English poetry, from Chaueer to Tennyson, has been rich in examples of wifely, womanly patienee, devotion, self-sacrifice. But, many and noble as they are, I think Santa Maura ought to rank among the best. I value the rhapsody not the less highly for the human element of hero-worship blended with the more purely celestial exaltation. I only hope that the austere preaeher of the Gospel, even as imagined by Kingsley, merited it all.

I had thought, and have not dared, to set beside the Three the Ode, admirable in itself, to the North-East Wind. As simple singing, in its exultant, generous insolence, it deserves all honour :

What's the soft South-Wester?

'Tis the ladies' breeze,

Bringing home their true-loves

Out of all the seas :

But the black North-Easter, Through the snow-storm hurled,

Drives our English hearts of oak

Seaward round the world.

Come, as came our fathers,

Heralded by thee,

Conquering from the eastward,

Lords by land and sea.

Come; and strong within us

Stir the Vikings' blood;

Bracing brain and sinew ;

Blow, thou wind of God ! 12

I feel, however, a spiritual want in the brave, blustering breeze, which shuts against it the region of immortal grief or bliss, where those other strains are entitled to have their dwelling.

The Three are lovely conceptions ; and we should have to ransack a library of poetry before discovering superiors in 
their own class. I do not suppose, nevertheless, that greatness could justly be attributed to their writer as a poet. For that a man's best work ought to suggest that it is supreme in quality because it flows from a fountain of inspiration in himself which is perennially full and deep. A completeness, perfection almost, which I have in my admiration attributed to a few of Charles Kingsley's poems, itself produces a suspicion of finiteness in the poetical source whence they issued. When the mass of an author's verse is self-complacently good in the second, and not the first, degree, the positive excellence of a small minority may well be presumed to be an accident of a theme and its circumstances rather than the fruit of a poet's being. It is impossible to question Kingsley's inspiration any more than his genius. It is permissible to believe that he held it at the general service of the wide circle of his life's work. His romances, his histories and essays are coloured by it ; even his sermons; and it beautifies them all. Never was there a nature, an intelligence, more generously cultivated, more sympathetic, more pervious to all the informing influences, to the entire spirit, of its race, rank, and age, throughout which more constantly breathed an independent element, the poetic. But inspiration to constitute distinctively a poet, and not a mere occasional singer, insists upon exclusiveness in the vocation. It punishes disobedience by relegating the offender to a lower grade ; and disobedience was thus punished here. Howbeit, of this at least I have no doubt-whatever Kingsley's personal status among poets-that, however jealous the principle on which a poetical anthology may be framed, verses of his are sure to be numbered in it. 
Andromeda and Other Poems, by Charles Kingsley, Rector of Eversley. London: John W. Parker \& Son, 1858. Also, Collected Edition. Macmillan, 1872.

1 Andromeda, vv. 106-11.

2 Ibid, vv. 391-3.

3 Margaret to Dolcino.

5 The Outlaw.

- 'The Ugly Princess.

- Airly Beacon.

- A Christmas Carol.

- The Sands of Dee.

8 The Swan-neck.

11 Santa Maura, A.D. 304.

10 The Three Fishers.

12 Ode to the North-East Wind. 


\section{RALPH WALDO EMERSON}

\section{$1803-1882$}

Emerson in the opinion of his own generation ranked next to Carlyle as a thinker. As a thinker he still is held, and justly, to be profound. The larger part in bulk of his literary life was devoted to the composition of essays and lectures. To a great number even of his admirers he is unknown as a poet. Yet I should be much surprised to learn that he did not value himself as a poet chiefly. If so, fallible as are authors on the proportionate value of their works, I believe he would in his preference have judged wisely. He might be, probably has already been, replaced as a philosopher; he could scarcely be as a poet. Literature would less easily do without Woodnotes, Forerunners, Bacchus, Monadnoc, than historical and critical science without Representative Men or Nature.

Deliberately he vowed himself to poetry, with a full sense of the obligations, even the divinity, of the calling. He became a voice with a message from the higher Powers. The poet must be mute until they unseal his mouth :

Ye taught my lips a single speech,

And a thousand silences. ${ }^{1}$

He need not sail the seas, or search humanity for sages to instruct him. At the destined moment the Angel is at hand :

Behold he watches at the door!

Behold his shadow on the floor!

Seek not beyond thy eottage wall

Redeemers that can yield thee all; 
While thou sittest at thy door

On the desert's yellow floor,

Listening to the gray-haired crones, Foolish gossips, ancient drones,

Saadi, see! they rise in stature

To the height of mighty Nature,

And the secret stands revealed

Fraudulent Time in vain concealed,-

That blessed gods in servile masks

Plied for thee thy household tasks. ${ }^{2}$

Let him dwell alone, not minding the reproach of sloth for folding his arms beside the woodland brook:

There was never mystery

But 'tis figured in the flowers;

Was never secret history

But birds tell it in the bowers. ${ }^{3}$

The pine-tree sings to him :

'Speak not thy speech my boughs among;

Put off thy years, wash in the breeze;

My hours are peaceful centuries.

Talk no more with feeble tongue;

No more the fool of space and time,

Come weave with me a nobler rhyme.

Only thy Americans

Can read thy line, can meet thy glance,

But the runes that $I$ rehearse

Understands the universe ;

The least breath my boughs which tossed

Brings again the Pentecost,

To every soul resounding clear

In a voice of solemn cheer,-

'Am I not thine? Are not these thine ?'

And they reply, 'Forever mine!'

Come learn with me the fatal song

Which knits the world in music strong,

Come lift thine eyes to lofty rhymes,

Of things with things, of times with times, 


\section{THE POETS}

Primeval chimes of sun and shade, Of sound and echo, man and maid, The land reflected in the flood, Body with shadow still pursued, For Nature beats in perfect tune, And rounds with rhyme her every rune ;

Whether she work in land or sea, Or hide underground her alchemy, Thou canst not wave thy staff in air, Or dip thy paddle in the lake!

But it carves the bow of beauty there, And the ripples in rhymes the oar forsake.

The wood is wiser far than thou ;

The wood and wave each other know.

Not unrelated, unaffied,

But to each thought and thing allied,

Is perfect Nature's every part,

Rooted in the mighty Heart.' 4

Spirit voices, though whence he never discovers, are continually sounding in his ear, to direct him on his way :

Long I followed happy guides,

I could never reach their sides ;

Their step is forth, and, ere the day,

Breaks up their leaguer, and away.

Flowers they strew, I catch the scent;

Or tone of silver instrument

Leaves on the wind melodious trace;

Yet I could never see their face.

I met many travellers,

Who the road had surely kept;

They saw not my fine revellers,-

These had crossed them while they slept.

Sometimes their strong speed they slacken,

Though they are not overtaken;

In sleep their jubilant troop is near,-

I tuneful voices overhear;

It may be in wood or waste,-

At unawares 'tis come and past. 
Their near camp my spirit knows

By signs gracious as rainbows.

I thenceforward, and long after,

Listen for their harp-like laughter,

And carry in my heart, for days,

Peace that hallows rudest ways. ${ }^{5}$

The pursuit after beauty and truth, though it has its solaces, is long, and never more than partially successful. The end is not, though the God will refresh him awhile with the cup of

Wine which Music is, -

That I, drinking this,

Shall hear far Chaos talk with me;

Kings unborn shall walk with me;

And the poor grass shall plot and plan

What it will do when it is man.

Quickened so, will I unlock

Every crypt of every rock. ${ }^{6}$

Still, will darkness and dumbness be. Although by happy fits,

The God's will sallies free,

And the dull idiot might see

The flowing fortunes of a thousand years,-

Sudden, at unawares,

Self-moved, fly-to the doors,

Nor sword of angels could reveal

What they conceal. ${ }^{7}$

The poet must learn to rule, and. as a Sovereign, he proclaims his royal edicts :

The kingly bard

Must smite the chords rudely and hard,

As with hammer or with mace ;

That they may render back

Awful thunder, which conveys

Secrets of the solar track,

Sparks of the supersolar blaze. ${ }^{8}$

Like the Supreme Pontiff, he is servus servorum also, and 
must learn to obey; mindful always that he is but a minister executing Another's behest. It is the lot of all great souls :

The hand that rounded Peter's dome,

And groined the aisles of Christian Rome,

Wrought in a sad sincerity ;

Himself from God he could not free ;

He builded better than he knew ;-

The conscious stone to beauty grew,

The passive Master lent his hand

To the vast soul that o'er him planned;

And the same power that reared the shrine

Bestrode the tribes that knelt within.

Ever the fiery Pentecost

Girds with one flame the countless host,

Trances the heart through chanting choirs,

And through the priest the mind inspires. ${ }^{9}$

Even to him, chosen though he be, only half-truths are disclosed. Existence is a Sphinx, constantly asking riddles beyond his power of guessing :

Thou art the unanswered question;

Couldst see thy proper eye,

Always it asketh, asketh ;

And each answer is a lie. ${ }^{10}$

Disappointment surely awaits him and his hearers, if he will not understand that

All are needed by each one ;

Nothing is fair or good alone.

I thought the sparrow's note from heaven,

Sitting at dawn on the alder bough ;

I brought him home, in his nest, at even ;

He sings the song, but it cheers not now,

For I did not bring home the river and sky :-

He sang to my ear,- they sang to my eye. ${ }^{11}$

He has no right to expect payment for his worship of Love not blind, but the 
radiant, sharpest-sighted god,

Whose eyes pierce the unirerse,

Path-finder, road-builder,

Mediator, royal giver. ${ }^{12}$

Let him not even, if rejected as a wooer, complain overmuch ; for,

When half-gods go,

The gods arrive. ${ }^{13}$

The business of the Poet-Soul is to strive to comprehend the working of the World-Soul. He must not be shocked at what may seem to be the deity's pitilessness :

He serveth the servant,

The brave he loves amain;

He kills the cripple and the sick,

And straight begins again ;

For gods delight in gods,

And thrust the weak aside ;

To him who scorns their charities,

Their arms fly open wide. ${ }^{14}$

Accordingly, he will neither quarrel with the government of the universe for dealing out poverty to one and wealth to another soon to be added

to his land, a lump of mould the more ; ${ }^{15}$

nor forget its bounty in

Spreading May's leafless blooms in a damp nook,

To please the desert and the sluggish brook ; ${ }^{16}$

in endowing with warmth and brightness, and honeyed shrubs and vines, the burly humble-bee :

Insect lover of the sun,

Joy of thy dominion!

Sailor of the atmosphere ;

Swimmer through the waves of air ;

Voyager of light and noon :

Epicurean of June ; ${ }^{17}$ 
in commissioning, in fine, to glorify this earth of ours, the beneficent Spirit of Beauty :

Guest of million painted forms, Which in turn thy glory warms !

The frailest leaf, the mossy bark,

The acorn's cup, the rainbow's arc,

The swinging spider's silver line,

The ruby of the drop of wine,

The shining pebble of the pond,

Thou inscribest with a bond,

In thy momentary play,

Would bankrupt nature to repay. ${ }^{18}$

Happy the man who has learnt to enjoy the feast prepared for him :

And such I knew, a forest seer,

A minstrel of the natural year,

A lover true, who knew by heart

Each joy the mountain dales impart;

It seemed that nature could not raise

A plant in any secret place,

In quaking bog, on snowy hill,

Beneath the grass that shades the rill,

But he would come in the very hour

It opened in its virgin bower,

As if a sunbeam showed the place,

And tell its long-descended race.

What others did at distance hear,

And guessed within the thicket's gloom

Was showed to this philosopher,

And at his bidding seemed to come. ${ }^{19}$

I am not concerned to expound the philosophy, which, generous, self-denying, reverent, as, in its own way it is, produces a prevailing impression, less of open day, than of a gorgeous sunset. As little do I care to defend the habit of trimming verse to fit the thought, instead of harmonizing both. But, whatever the differences in form and diction between Emerson and better recognized poets, at all 
events in one respect he can meet them on equal terms. With the greatest he shares the quality of passionate earnestness. Passion is an essential characteristic of pure poetry. A necessity of verse meant to move is that it shall have moved its author first. He must have been a little mad before his readers will feel the hurrying fire within themselves. Philosophy embodied in verse usually is heedless of this condition. Hence the disfavour with lovers of poetry under which commonly it labours. With Emerson thought of the profoundest acknowledges no servile obligation to be temperate and tame. That was not his nature.

The lovely dirge in which he laments his dead brothers amid the scenes they loved, itself glows throughout with a warm, clinging tenderness :

In the long sunny afternoon,

The plain was full of ghosts;

I wandered up, I wandered down,

Beset by pensive hosts.

The winding Concord gleamed below,

Pouring as wide a flood

As when my brothers, long ago,

Came with me to the wood.

But they are gone-the holy ones

Who trod with me this lovely vale;

The strong, star-bright companions

Are silent, low, and pale.

They coloured the horizon round;

Stars flamed and faded as they bade ;

All echoes hearkened for their sound,-

They made the woodlands glad or mad.

I touch this flower of silken leaf,

Which once our childhood knew ;

Its soft leaves wound me with a grief

Whose balsam never grew. 


\section{THE POETS}

Hearken to yon pine-warbler

Singing aloft in the tree !

Hearest thou, $\mathrm{O}$ traveller,

What he singeth to me ?

' Go, lonely man,' it saith ;

'They loved thee from their birth ;

Their hands were pure, and pure their faith,-

There are no such hearts on earth.

You cannot unlock your heart,

The key is gone with them;

The silent organ loudest chants

The master's requiem.' 20

But the fire and flame of fancy he reserved for explorations of the incomprehensible. In the majestic hymn, or treatise, in which he seems determined to prove by explaining it, that Godhead, as imagined in his scheme of Being, is inexplicable, he falls into an ecstasy :

This vault which glows immense with light

Is the inn where he lodges for a night.

What recks such Traveller if the bowers

Which bloom and fade like meadow flowers

A bunch of fragrant lilies be,

Or the stars of eternity ?

Alike to him the better, the worse,-

The glowing angel, the outcast corse.

Thou metest him by centuries,

And lo! he passes like the breeze;

Thou seek'st in globe and galaxy,

He hides in pure transparency ;

Thou askest in fountains and in fires,-

$\mathrm{He}$ is the essence that inquires.

$\mathrm{He}$ is the axis of the star,

$\mathrm{He}$ is the sparkle of the spar,

$\mathrm{He}$ is the heart of every creature,

$\mathrm{He}$ is the meaning of each feature;

And his mind is the sky,

Than all it holds more deep, more high. ${ }^{21}$ 
Thought, as it flows from him, turns into red-hot steam. The heat is no occasional accident; it is an inherent property. Philosophy in such guise may well claim for itself the prerogatives and honours of poetic inspiration; and none who study Emerson's verse will refuse them to it and him.

The Works of Ralph Waldo Emerson. Five vols. (vol. iv: Letters, Social Aims, Poems). Boston: Houghton, Mifflin \& Co., 1882. Also: The Complete Works of Ralph Waldo Emerson. Two vols. (vol. i, The Poems). London : G. Bell \& Sons, 1879.

(1. Merops, vol. i, p. 471 (1879 ed.).

2 Sardi, vol. iv, p. 39 (1882 ed.).

${ }^{3}$ The Apology, vol. i, p. 466 (1879 ed.).

- Woodnotes, ii, pp. 134-5 (1879 ed.).

${ }^{5}$ Forerunners, vol. iv, pp. 68-9 (1882 ed.).

- Bacchus, vol. iv, p. 118 (1882 ed.).

'Merlin, vol. iv, p. 116 (1882 ed.).

${ }^{\circ}$ Ibid., vol. iv, p. 114 (1882 ed.).

- The Problem, vol. iv, pp. 14-15 (1882 ed.).

10 The Sphinx, vol. iv, p. 11 (1882 ed.).

"Each and All, vol. iv, p. 12 (1882 ed.).

12 The Dæmonic Love, vol. iv, pp. 104-5 (1882 ed.).

${ }^{13}$ Give All to Love, vol. iv, p. 451 (1882 ed.).

is The World-Soul, p. 27 (1882 ed.).

${ }_{15}$ The Hamatreya, pp. 70-1 (1882 ed.).

${ }_{18}$ The Rhodora, p. 58 (1882 ed.).

${ }_{17}$ The Humble-bee, p. 59 (1882 ed.).

${ }_{18}$ Ode to Beauty, pp. 80-1 (1882 ed.).

19 Woodnotes, i, pp. 127-8 (1879 ed.).

${ }^{20}$ Dirge, p. 188-9 (1882 ed.).

${ }^{81}$ Woodnotes, ii, p. 140 (1879 ed.) 


\section{EDGAR ALLAN POE}

\section{$1811-1849$}

They are all dreams, if manufactured dreams-The Raven, Lenore, The Bells, Annabel Lee, Eulalie, Ulalume, Dreamland, The City in the Sea, A Dream within a Dream, For Annie, Bridal Ballad, Israfel, To Helen. We see things happening, being done, being suffered. We hear words. We speak them. Though we are there only because we are subject or object, we know we have nothing in reality to do with the whole. We are conscious that it is an illusion from which we are sure to wake up, if once we can shake ourselves. Throughout the entire range of poetry nothing like it is to be found; not Christabel; Kubla Khan may compare, though chiefly by way of contrast of the nature in it, with the artifice in Poe. In prose some of De Quincey's visions might stand in the same line, were they not pervaded by a palpable reasonableness. Poe's in a sense have neither thought nor feeling; and in a sense they are nothing else. Somewhere, several years ago, a writer supposed Man to possess, or be possessed by, two souls ; one immortal, a heavenly spark; the other at any rate not heavenly, and certainly mortal, capable of dying with the flesh. That is the sort of soul which animates Poe's verse, if not himself.

The grace and melody of most of his few poems are indisputable, and all but impossible to analyse and define. The charm is as inscrutable. In The Raven wave after wave of solemn mystery keeps rolling up. There is the opening scene : 
Once upon a midnight dreary, while I pondered, weak and weary, Over many a quaint and curious volume of forgotten lore ; While I nodded, nearly napping, suddenly there came a tapping, As of some one gently rapping-rapping at my chamber door. ' 'Tis some visitor,' I muttered, 'tapping at my chamber door ; Only this, and nothing more.'

Something seems about to happen, as, on the discovery that the sound is at the window lattice,

Open here I flung the shutter, when, with many a flirt and flutter, In there stepped a stately Raven of the saintly days of yore, Not the least obeisance made he ; not a minute stopped or stayed he ; But, with mien of lord or lady, perched above my chamber doorPerched upon a bust of Pallas just above my chamber door-

Perched, and sat, and nothing more.

'Nothing more' in fact; for :

the Raven, never flitting, still is sitting, still is sitting On the pallid bust of Pallas, just above my chamber door; And his eyes have all the seeming of a demon's that is dreaming, And the lamplight o'er him streaming throws his shadow on the floor ;

And my soul from out that shadow that lies floating on the floor Shall be lifted-nevermore ! 1

Yet, withal, a sentiment is produced that things of import are, and have been, happening, and will happen; that the atmosphere is surcharged with them; and that the key to the secret is held by the Raven.

Then there is the sister puzzle, Lenore :

Come, let the burial rite be read, the funeral song be sung ; An anthem for the queenliest dead that ever died so young,A dirge for her, the doubly dead, in that she died so young. ${ }^{2}$

Ever we seem to be clutching hold of the fringe of an idea, which, the moment we draw it nearer, breaks between our fingers : 
[Wretches ! ye loved her for her wealth and hated her for her pride, And when she fell in feeble health ye blessed her, that she died! How shall the ritual then be read-the requiem how be sung, By you-by yours, the evil eye-by yours, the slanderous tongue, That did to death the innocence that died, and died so young?' 's

Not that either is otherwise than clear and simple by the side of Ulalume! A maze of fantastic, intentionally dishevelled romance that; yet of an absurd, preposterous beauty, smelling strong of the lamp by the light of which doubtless it was conjured up, on the

when,

night in the lonesome October

Of my most immemorial year ;

through an alley Titanic

Of cypress, I roamed with my Soul,-

Of cypress, with Psyche, my Soul.

These were days when my heart was volcanic

As the scoriac rivers that roll,-

As the lavas that restlessly roll

Their sulphurous currents down Yaanek

In the ultimate climes of the pole,-

That groan as they roll down Mount Yaanek

In the realms of the boreal pole ! 4

Relatively the lay of The Bells is simple and sane, as they ring out their appeals of triumph, dismay, anger, and lamentation, till we feel, as it were, the tower rocking under our feet. It concerns us little-gratuitously cruel as seems the burden of the chimes-that

The people-ah, the people-

They that dwell up in the steeple,

All alone,

Tolling, tolling, tolling,

In that muffled monotone,

Feel a glory in so rolling

On the human heart a stone. ${ }^{5}$ 
Annabel Lee, besides being comparatively intelligible, even is sweet:

It was many and many a year ago,

In a kingdom by the sea,

That a maiden there lived whom you may know

By the name of Annabel Lee;

And this maiden she lived with no other thought

Than to love and be loved by me.

I was a child, and she was a child,

In this kingdom by the sea ;

But we loved with a love that was more than love,

I and my Annabel Lee;

With a love that the wingèd seraphs of heaven

Coveted her and me.

The angels not half so happy in heaven,

Went enrying her and me;

Yes! that was the reason-as all men know

In this kingdom by the sea-

That the wind came out of the cloud by night

Chilling and killing my Annabel Lee. ${ }^{6}$

And last, far from least, For Annie! On the face of it a riddle-or it would not be Edgar Allan Poe's-it is soon guessed; only, the answer is as enigmatical as the question. But the theme is grandly audacious, almost sublime; just an ecstasy of life's unexplained, perhaps inexplicable, perhaps unreal, unreasonable despair, become bliss through the embrace of Death by Love :

Thank Heaven, the crisis,

The danger is past,

And the lingering illness

Is over at last ;

And the fever called 'living'

Is conquered at last.

And I rest so composedly

Now in my bed, 
That any beholder

Might fancy me dead-

Might start at beholding me,

Thinking me dead.

And, 0 ! of all tortures

That torture the worst

Has abated-the terrible

Torture of thirst

For the naphthaline river

Of Passion accurst ;

I have drunk of a water

That quenches all thirst :-

And, ah! let it never

$\mathrm{Be}$ foolishly said

That my room it is gloomy

And narrow my bed;

For man never slept

In a different bed-

And, to sleep, you must slumber

In just such a bed.

And so I lie happily,

Bathing in many

A dream of the truth

And the beauty of Annie-

Drowned in a bath

Of the tresses of Annie.

She tenderly kissed me, She fondly caressed, And then I fell gently

To sleep on her breast-

Deeply to sleep

From the heaven of her breast.

When the light was extinguished

She covered me warm, And she prayed to the angels

To keep me from harm-

To the queen of the angels

To shield me from harm. 
And I lie so composedly

Now in my bed,

Knowing her love,

That you fancy me dead;

And I rest so contentedly

Now in my bed,

With her love at my breast,

That you fancy me dead-

That you shudder to look at me,

Thinking me dead.

But my heart it is brighter

Than all of the many

Stars in the sky,

For it sparkles with Annie-

It glows with the light

Of the love of my Annie-

With the thought of the light

Of the eyes of my Annie.?

After all the great poems I have been studying, I cannot read this without fresh surprise at the potentialities of poetry. Its death-cold passion is overpowering. I am inclined to rank it highest in Poe's poetic work. Nothing surpasses it in soaring fancy, or equals it in ideas and spiritual power.

At the same time, in method of workmanship I see little difference between it and the rest of his minute body of verse. In it, as elsewhere, I observe the deliberate laying of snares to surprise ; the same habit of recurrence to one theme. I find between it and, for instance, The Raven, a yet more intimate analogy ; a relationship of one to the other as its converse. Thus, in The Raven, the reader is continually led on to expect an event of import which never happens; in For Annie, the very ordinary idea which we supposed we were contemplating develops into a monstrosity of fancy at once ghastly and beautiful. 
Contrasted as are the results, I believe the art to be virtually identical. The effect Poe desired to compass by a poem was that of a single long-drawn sob or moan, floating one does not know whence; a thrill as when an untouched harpstring breaks in the dead night from a white-shrouded instrument in a dimly lighted room. It was a point of pride with him, both that he should be able to tell himself he had accomplished his object in conformity with rigid rules, and that his readers should never guess them.

He himself paraded in print the absence of spontaneous inspiration from his composition of The Raven. It was, he has told the world, the product of a mechanical operation he had cunningly devised. He who had boasted that with him 'poetry was not a purpose, but a passion', details elaborately how and why he introduced beauty, with its highest expression, sadness, and death ; a refrain, with a bird-by choice a raven-to repeat it, in unconscious unison with the throbbings of despair in dead Lenore's lover; and, beneath all, a suggestive undercurrent of meaning;--deliberately confining the whole within a few more than one hundred lines.

The explanation at the time tasked the capacity of popular belief more even than the weirdness of the poem hypnotized common understandings. A natural conjecture was that Poe either deceived himself into measuring back step by step ground his fancy had already taken in its stride, or simply was diverting himself with an experiment on public credulity. Really, however, what else would have been an altogether unlikely mystification if imputed to another poet, and poem, ceases to be incredible in respect to The Raven and him. The iron rigour with which there the thread-chain rather-of the central idea is stretched stiff and taut indicates, as I began by intimating, artifice rather 
than the unpremeditated harmony of imagination. With himself confirming the suspicion, it becomes at least practicable to persuade ourselves that we smell the sawdust and oil of the workshop.

Although no critic, not even Poe himself, has attempted to apply the extreme mechanical theory to others of his poems, it cannot be denied that in general they are liable to the charge of an excess of art. None breathe of simple nature. Even the elegance of the lines to Helen with her 'Naiad airs', which bring admirers

\section{home}

To the glory that was Greece,

And the grandeur that was Rome, ${ }^{8}$

is but dumb sculpture, though of ivory and gold. Even though a spontaneous spark-a lurid one-from the soul kindled the dead man's appeal to his love For Annie, its rush of fire was constrained, as if it had been Ulalume ; it had to flame along a line ruled for, not by, it. Never was verse of such apparent, and so little real, freedom as all of Poe's; or, consequently, so exquisite, which is less satisfying; so pure of loose taint with less of wholesome freshness. No healthful breeze blows from off its Dead Sea surface. No singing birds fly over it; though itself, in its ebb and flow, makes song, enthralling harmony, fairy music. Whatever he wrote, from his precocious and libertine, not idle, youth to the delirious end in the Baltimore hospital, possesses the same qualities of unfailing grace and tone. But the whole is like a reverie between sleep and waking, always fascinating, never restful, with an atmosphere about it as of a sepulchral vault.

The Poetical Works of Edgar Allan Poe, edited by James Hannay. London: Charles Griffin \& Co., 1852. 


\section{THE POETS}

1 The Raven, stanzas 1, 7, 18, pp. 35, 38, 44.

2 Lenore, st. 1, p. 46.

- Ibid., st. 2, p. 46.

- Ulalume, st. 2, p. 71.

- The Bells, st. 4, p. 65.

6 Annabel Lee, stanzas 1, 2, 4, pp. 67-8.

- For Annie, stanzas 1, 3, 6, 8, 11, 12, 14, 15, pp. 102-6.

- To Helen (Poems written in Youth), st. 2, p. 191. 


\section{HENRY WADSWOR'TH LONGFELLOW}

\section{$1807-1882$}

The poetry of echoes, of shadows, of wandering clouds, which have caught sunset purples. Literature numbers poets without family or descent, the first, some the last, of their line. Such were Homer, the Attic dramatists, Chaucer, the Elizabethans, Chatterton, Burns. There have been poets, great poets, with ancestry and successors, like Pope. Others, genuine too, there have been; manifestly foster children, suckled on milk of strangers, and in an atmosphere not their own. In default of examples and models from with. out, they might never have sung. Such is Longfellow. If inspiration ever were traceable, it would be seen that his library had inspired him. Diction and manner he seldom borrows; impulses, emotions, constantly. The limitations observable in his work are the inevitable consequences. No Pindaric strain is to be expected; no soaring to the heights. Momentum thus adventitious is exhausted too soon to supply impetus for a free career. It is an admirable supplement to native sweetness, intelligence, tenderness, sense of picturesqueness. A hundred delicate chords must have been thrilling through Longfellow's temperament, as the vibrations of extraneous, scarcely alien, minstrelsy touched them into music. To many natures the counter-note is actually more delightful, more awakening, than the unsoftened, full principal. Certainly the reflected character of the melody is the secret of the charm of a lovely ghost of medievalism like the Golden Legend. 
Never was poet humbler towards his elders in the vocation; more modest and reverential; yet in a sense also more exacting. His nature incorporated as much as it could of other poetic souls. Something was extracted here, something there. Every constituent in the new creation was real, with characteristics of its own, but compressed to meet the demands of the rest. Each was kept malleable to receive a stamp from the borrowing self. That self was thoughtful without being a thinker; given to learning, not to research; sympathetically inquisitive, not philosophic ; accustomed to look to a printed page to put fancy in motion. From the vast store of his reading Longfellow selected instinctively whatever he could assimilate and feel. In his poems we have the fruit of his studies ; and their essence has become his. There the explanation is of the anger, the bitter contempt, which his successive earlier volumes stirred in divers critics at the times of their appearance. They were irritated by catching and losing hold continually of clues to sources from which he had drawn. They raged at the self-complacency, as they regarded it, with which he propounded discoveries by illustrious predecessors as novelties of his own. They did not care to understand that his poetry came finally from his heart, whencesoever its elements might have been derived; that what to them were truisms were for him very truths. For his public they were truths too, and living truths. He was absolutely sincere when he preached venerable moralities, like the Psalm of Life and Excelsior, as a new Gospel. The undoubting confidence with which he proclaimed it, if it raised up scoffers by the dozen, brought him disciples by the ten thousand.

The jeers, coming from the intellectual class in the Old Country, must, I am afraid, have caused aches beyond the 
power of applause by the multitude to heal. All his work indicates a delicate, sensitive organism. It was an accident that his early popularity was largely due to some sounding platitudes. Platitudes are not necessarily criminal. Literature is paved with them. Often they have been with our greatest the nursing-mothers of royal sublimities. In Longfellow's verse they are naive and graceful; but it was his misfortune that they won him admiration, which, for poets to be allowed to bear it in comfort, ought to fall, a halo, from above, and not steam rankly up from below. He endured the consequent obloquy, however wounding, with uncomplaining dignity. He did not, like famous English contemporaries, turn upon his assailants, and rend them.

The excellence of some of his work had never been denied, and was indisputable. His translations, especially from the German and Spanish, are full of beauty. That of Coplas de Manrique's Ode on his father Rodrigo's death is dignified and noble. Others from Müller, Uhland, Salis, Mosen, enhance the merits of the originals. Take, for examples, Whither? the Statue over the Cathedral Door, the legend of the Crossbill, and the lovely Song of the Silent Land :

Into the Silent Land !

Ah! who shall lead us thither ?

Clouds in the evening sky more darkly gather,

And shattered wrecks lie thicker on the strand.

Who leads us with a gentle hand

Thither, $\mathbf{O}$ thither,

Into the Silent Land ?

Into the Silent Land ?

To you, ye boundless regions

Of all perfection! Tender morning-visions

Of beauteous souls! The Future's pledge and band ! 
Who in Life's battle firm doth stand,

Shall bear Hope's tender blossoms

Into the Silent Land !

$O$ Land ! O Land !

For all the broken-hearted

The mildest herald by our fate allotted,

Beckons, and with inverted torch doth stand

To lead us with a gentle hand

Into the land of the great Departed,

Into the Silent Land ! 1

Gradually the sneering even at his original verse went out of fashion, as volume after volume demonstrated an unmistakeable poet. Evangeline had been a revelation to many; and surely fancy rarely has created a sweeter maiden, equal alike to joy and tears :

Fair was she to behold, that maiden of seventeen summers;

But a celestial brightness-a more ethereal beauty-

Shone on her face and encircled her form, when, after confession, Homeward serenely she walked with God's benediction upon her. When she had passed, it seemed like the ceasing of exquisite music. ${ }^{2}$

Purists could bring no graver reproach than the hexameters. Hiawatha, notwithstanding its hendecasyllables, converted others. Mark Pattison, who objected to Longfellow for his indulgence in truisms, was obliged to praise the comparison of the advent of jostling human disasters to the gathering of a swarm of vultures :

Never stoops the soaring vulture

On his quarry in the desert,

On the sick or wounded bison,

But another vulture, watching

From his high aerial look-out,

Sees the downward plunge, and follows ;

And a third pursues the second,

Coming from the invisible ether,

First a speck, and then a vulture,

Till the air is dark with pinions. ${ }^{3}$ 
The wonder to me is, as I recall the fight on the poet's behalf, how any opposition should have survived the still earlier publication of a romance so enchanting as The Golden Legend.

At present controversy is over ; and Longfellow's place is assured. For many, whom Shelley, Wordsworth, Keats, Browning, only dazzle, tire, or bewilder, poetry nevertheless is a necessity of existence. On their natures Longfellow's serene imaginings shed an effluence comforting and tranquillizing. They are not offended by a lack of originality and profundity, as in Footsteps of Angels, when in the firelit dusk,

the forms of the departed

Enter at the open door;

The beloved, the true-hearted,

Come to visit me once more ; ${ }^{4}$

in the reminiscence of a walk to church

with thee,

O gentlest of my friends !

Thy dress was like the lilies,

And thy heart as pure as they ;

One of God's holy messengers

Did walk with me that day.

I saw the branches of the trees

Bend down thy touch to meet,

The clover-blossoms in the grass

Rise up to kiss thy feet ; ${ }^{6}$

in The Bridge, with its

long procession

Still passing to and fro,

The young heart hot and restless,

And the old subdued and slow ; ${ }^{\circ}$

in the laudation of the red Planet Mars : 
The star of the unconquered will,

He rises in my breast,

Serene, and resolute, and still,

And calm, and self-possessed ; ${ }^{7}$

in The Reaper and the Flowers :

'My Lord has need of these flowerets gay,

The Reaper said, and smiled;

' Dear tokens of the earth are they,

Where he was once a child.

They shall all bloom in fields of light,

Transplanted by my care,

And saints upon their garments white,

These sacred blossoms wear ; '

or in Blind Bartimeus's importunate petition, with its musical Greek. 9 They only know, and are content to know, that such strains calm troubled nerves, and touch the heart.

Even persons who habitually require of poetry that it shall stimulate and inflame, have occasional moods inclining them to listen to gentler music :

Not from the grand old masters,

Not from the bards sublime,

Whose distant footsteps echo

Through the corridors of Time.

For, like strains of martial music,

Their mighty thoughts suggest

Life's endless toil and endeavour ;

And to-night $I$ long for rest.

Read from some humbler poet,

Whose songs gushed from his heart,

As showers from the clouds of summer,

Or tears from the eyelids start.

And the night shall be filled with music,

And the cares that infest the day,

Shall fold their tents, like the Arabs,

And as silently steal away. ${ }^{10}$ 
Nowhere may the thought, the feeling itself, rise from unknown depths; but the singer had been in spiritual companionship with great minds of the past and the present; and a consciousness, dim, suspicious, and hesitating at first, came at length to pervade each side of the Atlantic that his lesser instrument beat time in unison with theirs.

Never, indeed, was there a more grateful, a more enthusiastic sympathy than his. He rejoiced to dwell upon grand deeds as well as upon grand thoughts. His fancy haunted the scenes of memorable actions, and the homes of their doers. For many of us it is impossible to visit cities where he has been without tracing his footsteps by a gracious light they have left behind them. We find him in Nuremberg attending the illustrious in song and art :

Here, when Art was still religion, with a simple reverent heart, Lived and laboured Albrecht Dürer, the Evangelist of Art ; Hence in silence and in sorrow, toiling still with busy hand, Like an emigrant he wandered, seeking for the Better Land.

'Emigravit' is the inscription on the tombstone where he lies ; Dead he is not-but departed-for the artist never dies.

Fairer seems the ancient city, and the sunshine seems more fair That he once has trod its pavement, that he once has breathed its air! 11

His verse beautifies Würtzburg's minster towers with the memory of Walter von der Vogelweid the Minnesinger, and his bequest to his teachers in the art of song :

Thus the bard of love departed;

And fulfilling his desire,

On his tomb the birds were feasted

By the children of the choir.

There they sang their merry carols,

Sang their lauds on every side;

And the name their voices uttered

Was the name of Vogelweid. 
Time has long effaced the inscriptions

On the cloister's funeral stones, And tradition only tells us

Where repose the poet's bones.

But around the vast Cathedral,

By sweet echoes multiplied,

Still the birds repeat the legend,

And the name of Vogelweid. ${ }^{12}$

If I were ever, as doubtless I shall never be, in the Palace of Palermo, modern as it is, I should expect

through the open window, loud and clear,

To hear the monks chant in the Chapel near,

Above the stir and tumult of the street :

' He has put down the mighty from their seat,

And has exalted them of low degree.' 13

For thousands of travellers since Longfellow, have.

As the evening shades descended,

Low and loud and sweetly blended,

Low at times and loud at times,

And changing like a poet's rhymes,

Rang the beautiful wild chimes

From the belfry in the market

Of the ancient town of Bruges.

They still have heard, blending with their dreams,

those magic numbers,

As they loud proclaimed the flight

And stolen marches of the night;

Till their chimes in sweet collision

Mingled with each wandering vision,

Mingled with the fortune-telling

Gipsy-bands of dreams and fancies,

Which amid the waste expanses

Of the silent land of trances

Have their solitary dwelling. ${ }^{14}$

Peculiar, and exotic, as, for twentieth-century Europe, 
remains the capital of Bohemia, the American studentpoet's track will be discernible there too by an added touch of eeriness through his

legend strange and vague, That a midnight host of spectres pale

Beleaguered the walls of Prague.

Beside the Moldau's rushing stream,

With the wan moon overhead, There stood, as in an awful dream, The army of the dead.

White as a sea-fog, landward bound, The spectral camp was seen, And, with a sorrowful, deep sound, The river flowed between. ${ }^{15}$

The old world early laid its spell upon Longfellow's fancy; and it was never taken off. We see in the story, truly Golden, of Elsie and Prince Henry of Hoheneck, how potent and lasting was the impress. Scholars might discover errors and misconceptions in that delightful Mystery. Few, I think, will care to deny its fidelity to the spirit. At all events the charm of its scenes, almost bewildering in their variety, is irresistible. There is a fine humour in the portraiture of the glorious Cellarer of the Black Forest monastery, as he samples, to begin, tho precious wine of the Holy Ghost :

Ah ! how the streamlet laughs and sings !

What a delicious fragrance springs

From the deep flagon, while it fills,

As of hyacinths and daffodils !

Between this cask and the Abbot's lips

Many have been the sips and slips.

$\mathbf{O}$ cordial delicious ! $\mathbf{O}$ soother of pain !

It flashes like sunshine into my brain ! 
And now a flagon for such as may ask A draught from the noble Bacharach cask, And I will be gone, though I know full well The cellar's a cheerfuller place than the cell. ${ }^{16}$

The devotion to his art of the Friar in the Scriptorium, as he closes work at dusk, and gazes from his window, makes a delightful contrast :

How sweet the air is! How fair the scene !

I wish I had as lovely a green

To paint my landscapes and my leaves!

How the swallows twitter under the eaves!

There, now, there is one in her nest;

I can just catch a glimpse of her head and breast, And will sketch her thus in her quiet nook,

For the margin of my Gospel book. ${ }^{17}$

And, lastly, the ecstasy of Monk Felix-taught, by the lapse of a hundred years in as many moments of a bird's song, that nothing with God is impossible-is something to dream of :

One morning, all alone,

Out of his convent of gray stone,

Into the forest, older, darker, grayer,

His lips moving as if in prayer,

His head sunken upon his breast,

As in a dream of rest,

Walked the Monk Felix. All about

The broad, sweet sunshine lay without,

Filling the summer air ;

And within the woodlands as he trod,

The twilight was like the Truce of God

With worldly woe and care ;

Under him lay the golden moss ;

And above him the boughs of hemlock-trees

Waved, and made the sign of the Cross,

And whispered their Benedicites.

He heeded not, but pondered

On the volume in his hand, 
A volume of Saint Augustine,

Wherein he read of the unseen

Splendours of God's great town

In the unknown land,

And, with his eyes cast down

In humility, he said :

'I believe, O God,

What herein I have read,

But, alas ! I do not understand !'

And lo! he heard

The sudden singing of a bird,

A snow-white bird that, from a cloud

Dropped down,

And among the branches brown

Sat singing

So sweet, and clear, and loud,

It seemed a thousand harpstrings ringing.

And the Monk Felix closed his book,

And long, long,

With rapturous look,

He listened to the song,

And hardly breathed or stirred,

Until he saw, as in a vision,

The land Elysian,

And in the heavenly city heard

Angelic feet

Fall on the golden flagging of the street.

And he would fain

Have caught the wondrous bird,

But strove in vain;

For it flew away, away

Far over hill and dell,

And instead of its sweet singing

He heard the Convent bell

Suddenly in the silence ringing

For the service of noonday.

And he retraced

His pathway homeward sadly and in haste. ${ }^{18}$

If the many productions of Longfellow's later years did 
not often rise to the level of this, yet things of beauty were interspersed; and already he had permanently triumphed over prejudice and fastidiousness. Had he been one to boast, he might have claimed that English literature could more easily dispense with several of his brilliant contemporaries than with him. Nevertheless-I cannot but suspect, cannot but fear, that the singer of the woful and sweet tragedy of Grand-Pré, of the Indian Edda-as various as it is harmonious - of the frankness of the bright Puritan maiden, of the Golden Legend itself, may sometimes have sighed to himself, as his brush laid-on his silvery moonlight, or evening afterglow-may have been tempted to envy the stormy passionateness of members of his craft both in the New World and the Old-may have complained of his Muse that she was placidly content to reflect the radiance of other suns instead of burning with fire of her own.

The Poetical Works of Henry Wadsworth Longfellow. Complete Edition. London: George Routledge \& Sons, 1865.

1 Song of the Silent Land. From the German of Salis, p. 27.

2 Evangeline, Part I, pp. 103-4.

3 The Song of Hiawatha, XIX, The Ghosts, p. 240.

- Footsteps of Angels, p. 4.

- The Bridge, p. 303.

- A Gleam of Sunshine, p. 294.

${ }^{8}$ The Reaper and the Flowers, pp. 3-4.

- Blind Bartimeus, p. 290.

10 The Day is Done, stanzas 5, 6, 7, 10, 11, p. 97.

11 Nuremberg, pp. 296-7.

${ }^{12}$ Walter von Vogelweid, p. 99.

${ }_{13}$ King Robert of Sicily, p. 220.

14 The Belfry of Bruges: Carillon, pp. 291 and 292.

15 The Beleaguered City, p. 5. 16 The Golden Legend, iv, pp. 171-2.

17 Ibid., iv, p. 173.

18 Ibid., ii, p. 150. 


\section{JAMES RUSSELL LOWELI}

\section{$1819-1891$}

Lowell might be forgiven if in later life he had grown jealous of Hosea Biglow. The Biglow Papers shone with a brilliancy which, in the eyes of the ordinary reader, put out the flame of a lifetime of serious poetizing. By many admirers of the Papers it seems almost to be forgotten even now that their author was a poet by profession. Certainly very few act as if they were aware that his poetry is of a kind particularly requiring quiet, intelligent, and, I may say, continuous, study. Not that his crusade of satire against slavery was a casual adventure, or tour de force, outside of his regular course. On the contrary, it was a natural stage in his career, and ought to be reckoned as one of its milestones. He did not belong to the old order of poets. They were by profession, as it might happen, soldiers and sailors, courtiers, diplomatists, politicians, churchmen, mystics, dramatists, men of letters, first. By compulsion of imagination, or by accident, they were poets afterwards. As little is he to be classed among those who in these latter days have fenced round for themselves a life apart, as a shrine for their chosen Muse. It could not have occurred to him to appropriate his age with its joys, troubles, and interests, as mere material and incentive for inspiration. He never dissembled either his occupation of poet, or that as poet he was citizen also, and fighter, and preacher. Wherever the battle of humanity was hottest, there was he to be found, with his lyre. In the intervals 
he mounted the pulpit. His poems, the serious as much as the burlesque and satirical, the Ghost-Seer, and Hunger and Cold, equally with the Biglow Papers, are part of the history of the period and its thought. Justly to appreciate cither sort, his reader must in memory, or in fancy, descend into the field, and imagine himself a combatant.

A necessary result is some risk of confusing in the poetry matter and spirit. The ethereal is apt to get chained to an incident antiquated or dead. When the subject-matter is philosophy, it is philosophy blown red-hot with disputation. The song, which at the time it was sung was itself the comment, now itself wants commentaries. Not everybody is able, and comparatively few are at pains, to read between the lincs. Then too the poet's impetuous fluency adds to the turmoil. His fancy exulting in the chances of a fiery conflict, whether to end in a victory or a rout, would burst into a rush of verse. On it sped, disdaining to be stayed while there was a public still passionate enough to supply readers. As I turn page after page, it is tantalizing to feel that a living idea, a burning thought, is gasping for breath beneath a cinder-pile of newspaper wranglings, or of free-fights in Congress. To its lovers poetry is self-sufficing, a being with a complete life of its own, neither a conflagration, nor a scaffolding. They are no better pleased when the bard abandons party strife, and takes, as his legitimate and normal vocation, to philosophy. Readers of Lowell are generally between Scylla and Charybdis. They are offered their choice of vital social and metaphysical problems to guess, one more intricate than another. He never sat down to write a line without a driving sense of a message to deliver, now down upon earth, and now aloft among the stars. His public is expected to follow and decipher the whole. Wisdom, 
generous indignation, phosphoric wit, criticism constructive as well as destructive, lightnings opening Heaven as they strike the earth, are all there. The pity is that too often either the thinker has overlaid the poet, or the inspiration is playing about a dead theme. It is as when a canvas has rotted under a masterpiece of art.

The poet, however, is there always, though, it may be, in the background; it is the readers, I am afraid, who are likely to be in default. The general public neither interests itself in bygone partisanships, nor has spare intelligence for dialectics. Even an enthusiast for poetry does not expect to have to keep the fire on his hearth alight with the ashes of yesterday, or steam coal. None could perceive more clearly how he missed popularity for his graver verse, or bear the loss more cheerfully, than Lowell himself :

Who's striving Parnassus to climb

With a whole bale of isms tied together with rhyme $;^{1}$

and, visiting Chartres,

to feed my eye,

And give to Fancy one clear holiday,

Scarce saw the minster for the thoughts it stirred ; -

The painted windows, freaking gloom with glow,

Dusking the sunshine which they seem to cheer,

Meet symbol of the senses and the soul,

And the whole pile, grim with the Northman's thought

Of life and death, and doom, life's equal fee. ${ }^{2}$

When the poet is working in him, and not, apparently, the thinker, he still is as much of a meditator as a minstrel. The sadder and more pensive phases of human experience are those to which he turns by preference. He mourns the death of an infant son:

A cherub who had lost his way

And wandered hither, so his stay 
With us was short, and 'twas most meet That he should be no delver in earth's clod, Nor need to pause and cleanse his feet To stand before his God: Oh, blest word-Evermore ! 3

The contrast between universal laughing, busy nature and the sudden pause and muteness of death surprises: and bewilders him :

The bee hums on; around the blossomed vine

Whirs the light humming-bird; the cricket chirps ;

The locust's shrill alarum stings the ear ;

Hard by, the cock shouts lustily ; from farm to farm,

His cheery brothers, telling of the sun,

Answer, till far away the joyance dies :

We never knew before how God had filled

The summer air with happy living sounds ;

All round us seems an overplus of life,

And yet the one dear heart lies cold and still. ${ }^{4}$

He gazes down, while he shudders, at the abyss, yet deeper than the grave, which separates the nearest and dearest from the darkened mind :

There thou sittest; now and then thou moanest;

Thou dost talk with what we cannot see,

Lookest at us with an eye so doubtful,

It doth put us very far from thee ;

There thou sittest; we would fain be nigh thee,

But we know that it can never be.-

Strange it is that, in this open brightness,

Thou shouldst sit in such a narrow cell ;

Strange it is that thou shouldest be so lonesome

Where those are who love thee all so well;

Not so much of thee is left among us

As the hum outliving the hushed bell. ${ }^{5}$

Akin to the attraction-with more still in it of the attraction of repulsion-which draws him to the contem- 
plation of the mystery of death, is the impulse to picture the contrast of luxury and want. Amid scenes of careless, wasteful revelry, he ever is seeing how at the gay dancers two grim Sisters, with

Wolves' eyes, through the windows peer ;

Little dream they you are near, Hunger and Cold,-

Scatter ashes on thy head,

Tears of burning sorrow shed,

Earth ! and be by Pity led

To Love's fold ;

Ere they block the very door

With lean corpses of the poor,

And will hush for naught but gore,

Hunger and Cold ! ${ }^{\circ}$

It is like him that he allows a farewell glow of light and happiness to cheer sheer forlornness, though perhaps arising from guilt :

The sharp storm cuts her forehead bare,

And piercing through her garments thin,

Beats on her shrunken breast, and there

Makes colder the cold heart within.

She lingers where a ruddy glow

Streams outward through an open shutter,

Adding more bitterness to woe,

More loneness to desertion utter.

She hears a woman's voice within,

Singing sweet words her childhood knew,

And years of misery and sin

Furl off, and leave her heaven blue.

Enhaloed by a mild, warm glow,

From man's humanity apart,

She hears old footsteps wandering slow

Through the lone chambers of the heart.- 
Next morning something heavily

Against the opening door did weigh, And there, from sin and sorrow free,

A woman on the threshold lay.-

For, whom the heart of man shuts out,

Sometimes the heart of God takes in, And fences them all round about

With silence 'mid the world's loud din. ${ }^{7}$

But for soulless greed, for the irredeemably lost bondsmen of gold, whom he meets in the noisy City's streets, his creed spares not a glimmer :

They pass me by like shadows, crowds on crowds,

Dim ghosts of men, that hover to and fro,

Hugging their bodies round them, like thin shrouds

Wherein their souls were buried long ago.

Lo! how they wander round the world, their grave, Whose ever gaping maw by such is fed, Gibbering at living men, and idly rave, 'We, only, truly live, but ye are dead.' Alas! poor fools, the anointed eye may trace A dead soul's epitaph in every face $!^{8}$

Happily he possessed, and from time to time used, the gift of simple sweetness, as well as those of preacher and judge. Readers, if they please, may sun themselves in pure charm, seeking nothing further. The deafness to divine singing, until the minstrel has departed back to his native Heaven, was never more prettily moralized than in the ballad of the exile of Phebus Apollo from Olympus to the sheep-folds of King Admetus :

Men granted that his speech was wise, But, when a glance they caught

Of his slim grace and woman's eyes,

They laughed, and called him good-for-naught. 


\section{JAMES RUSSELL LOWELL}

Yet after he was dead and gone, And e'en his memory dim,

Earth seemed more sweet to live upon,

More full of love, because of him.

And day by day more holy grew

Each spot where he had trod,

Till after-poets only knew

Their first-born brother as a God. ${ }^{9}$

As his pen wanders about the glades, the forest becomes

a woodland enchanted !

The great August moonlight,

Through myriad rifts slanted,

Leaf and bole thickly sprinkles

With flickering gold ;

There in warm August gloaming

With quick, silent brightenings,

From meadow-lands roaming,

The fire-fly twinkles

His fitful heat-lightenings.

The little fount twinkles

Its silver saints'-bells, That no sprite ill-boding

May make his abode in

Those innocent dells. ${ }^{10}$

He dreams bright dreams, as he watches the despised dandelion fringing in blithesome May the dusty road with harmless gold :

Then think I of deep shadows on the grass,

Of meadows where in sun the cattle graze,

Where, as the breezes pass,

The gleaming rushes lean a thousand ways,

Of leaves that slumber in a cloudy mass

Or whiten in the wind, of waters blue

That from the distance sparkle through

Some woodland gap, and of a sky above,

Where one white cloud, like a stray lamb, doth move.11

Heaven and earth seem to meet in his tale of the Christvol. II 
like Yussouf's dealing with the outcast, whom he was helping with horse and money to flee the avengers of blood :

' O Sheik, I cannot leave thee so ;

I will repay thee; all this thou hast done

Unto that Ibrahim who slew thy son!'

'Take thrice the gold,' said Yussouf, 'for with thee Into the desert, never to return,

My one black thought shall ride away from me ;

First-born, for whom by day and night I yearn,

Balanced and just are all of God's decrees ;

Thou art avenged, my first-born; sleep in peace !' 12

Reader, like poet, will be haunted by the picture of the maiden attended home from a dance, and left at her door holding a candle to light her cavalier, as he drives away down the rainy, dark avenue :

The vision of scarce a moment, And hardly marked at the time,

It comes unbidden to haunt me,

Like a scrap of ballad-rhyme.

Had she beauty? Well, not what they call so ;

You may find a thousand as fair ;

And yet there's her face in my memory

With no special claim to be there.

As I sit sometimes in the twilight,

And call back to life in the coals

Old faces and hopes and fancies

Long buried-good rest to their souls !-

Her face shines out in the embers;

I see her holding the light,

And hear the crunch of the gravel

And the sweep of the rain that night.

'Tis a face that can never grow older,

That never can part with its gleam,

'Tis a gracious possession forever,

For is it not all a dream ? 13 
Melody scarcely ever fails him. Often it is so bewitching as to tempt us to forget a fine thought in the sweet rhythm, as In the Twilight, where he likens the ghosts from Dreamland :

Of a life lived somewhere, I know not

In what diviner sphere,

Of memories that stay not and go not,

to the legend of the origin of the violin's music in the instrument's regrets for old forest voices :

The secrets of the wind it sings ;

It hears the April-loosened springs ;

And mixes with its mood

All it dreamed when it stood

In the murmurous pine-wood

Long ago !

The magical moonlight then

Steeped every bough and cone;

The roar of the brook in the glen

Came dim from the distance blown;

The wind through its glooms sang low,

And it swayed to and fro

With delight as it stood,

In the wonderful wood,

Long ago ! ${ }^{14}$

I do not pretend that all, or nearly all, Lowell's verse rises to the heights of inspiration. Too often it is prolix. Much of it again is to be regarded, as I have intimated, less as poetry than, if not skirmishings in a tournament of wit, as a species of journalism in excelsis, or metrical exercises in philosophy. The residuum, however, is undoubted poetry, and of a high order. Born of a rich nature, a passionate soul, it makes hearts to glow, brains to teem with ideas. I cannot read it without a shock at the thought that nine out of ten Englishmen well-read in the Biglow 
Papers, for whom Longfellow is as a compatriot, who even are familiar with the names of Whittier and Bryant, would be amazed to hear of James Russell Lowell as among the world's poets.-Yet he is.

The Poetical Works of James Russell Lowell. Household Edition. Boston: Houghton, Mifflin \& Co., 1882.

1 A Fable for Critics, p. 337.

2 The Cathedral, p. 434.

${ }^{3}$ Threnodia (Earlier Poems), p. 2.

4 On the Death of a Friend's Child (Miscellaneous Poems), pp. 99-100.

5 The Darkened Mind (Under the Willows), p. 398.

- Hunger and Cold (Miscellaneous Poems), p. 70.

2 The Forlorn (Earlier Poems), p. 16.

${ }_{8}^{8}$ The Street (Sonnets), p. 28.

9 The Shepherd of King Admetus (Miscellaneous Poems), p. 50.

${ }^{10}$ The Fountain of Youth (Under the Willows), p. 395.

${ }^{11}$ To the Dandelion (ibid.), pp. 94-5.

${ }^{12}$ Yussouf (ibid.), p. 397.

${ }^{13}$ An Ember Picture (Under the Willows), pp. 410-11.

14 In the Twilight (ibid.), pp. 412-13. 


\section{EDWARD FI'TZGERALD}

\section{$1809-1883$}

IT is at once easy and hard to account for the FitzGeraldCult. The fervour of many believers in the gospel propounded, 'according to Edward FitzGerald,' by the Persian astronomer-poet, is intelligible enough. The faith is that of Epicurus without the incubus of a philosophical system. None could be simpler, or more cheerfully practised. Live your life on earth as if earth, not you, were eternal ; as if there were neither Heaven, nor Hell. Live for the day, without concern for the morrow, if there be a morrow; any more for that than for yesterday. Play, if you can find no better diversion, with whatever theories or dogmas, religious or otherwise, you please. Never, at all events, allow them to colour or cloud your fleeting moments. Your active business is to take advantage of the pleasures of the body, while you have a body. Especially, enjoy music and drinking; if in a garden of roses, so much the better. Therein lies all your duty, which is only to yourself. Never was a more unethereally agreeable creed preached. But many students of FitzGerald who abhor Omar Khayyám's philosophy enthusiastically appreciate the verse; and it is much less difficult to explain acceptance of the one than why the other satisfies to the point of rapture.

FitzGerald interpolated into the laborious indolence he loved a bare modicum of poetical work. Of the pieces directly original the most important is Bredfield Hall. The description of the home of successive squires of his race is deliciously simple : 
Lo, an English mansion founded

In the elder James's reign,

Quaint and stately, and surrounded

With a pastoral domain.

With well-timber'd lawns and gardens, And with many a pleasant mead,

Skirted by the lofty coverts

Where the hare and pheasant feed.

Flanked it is with goodly stables, Shelter'd by coeval trees ;

So it lifts its honest gables

Toward the distant German seas ;

Where it once discern'd the smoke

Of old sea-battles far away ;

Saw victorious Nelson's topmasts

Anchoring in Hollesley Bay.

But whatever storm might riot,

Cannon roar, and trumpet ring,

Still amid these meadows quiet

Did the yearly violet spring ;

Still Heaven's starry hand suspended

That light balance of the dew,

That each night on earth descended, And each morning rose anew ;

And the ancient House stood rearing

Undisturb'd her chimneys high, And her gilded vanes still veering Toward each quarter of the sky :

While like wave to wave succeeding Through the world of joy and strife, Household after household speeding Handed on the torch of life.

Here they lived, and here they greeted,

Maids and matrons, sons and sires, Wandering in its walks, or seated

Round its hospitable fires; 
Till the bell that not in vain

Had summoned them to weekly prayer,

Call'd them one by one again

To the Church-and left them there !

They, with all their loves and passions,

Compliment, and song, and jest,

Politics, and sports, and fashions,

Merged in everlasting rest !

So they pass-while thou, old Mansion,

Markest with unalter'd face

How like the foliage of thy summers

Race of man succeeds to race.

To most thou stand'st a record sad,

But all the sunshine of the year

Could not make thy aspect glad

To one whose youth is buried here,

In thine ancient rooms and gardens

Buried-and his own no more

Than the youth of those old owners,

Dead two centuries before.

Unto him the fields around thee

Darken with the days gone by ;

O'er the solemn woods that bound thee

Ancient sunsets seem to die.

Sighs the selfsame breeze of morning

Through the cypress, as of old ;

Even at the Spring's returning

One same crocus breaks the mould.

Yet the secret worm ne'er ceases,

Nor the mouse behind the wall;

Hearts of oak will come to pieces,

And farewell to Bredfield Hall ! 1

In general he preferred to track and develop other imaginations, in the way of 'Translation, Paraphrase, or Metaphrase'. Thus he printed versions of six of Calderon's 
plays, and of three Greek tragedies, Oedipus, in Thebes, and at Athens, and Agamemnon. He added one of Virgil's garden, and renderings of Omar Khayyám's Rubáiyát, and Jaimi's Salaman and Abjal. All testify to unsparing pains, and an extraordinary gift in him for imagining himself into his author. At times we might almost say that he was the author; as in the tale by the Argive Chorus in the Agamem. non, 'taken from Aeschylus,' of the use by Fate of the passions of Gods and Men to accomplish its dread decrees.

That magnificent Ode laid a spell upon me when long ago

I came upon it ; and the charm works still :

Soon or late sardonic Fate

With Man against himself conspires ;

Puts on the mask of his desires:

Up the steps of Time elate

Leads him blinded with his pride,

And gathering as he goes along

The fuel of his suicide :

Until having topt the pyre

Which Destiny permits no higher,

Ambition sets himself on fire;

In conflagration like the crime

Conspicuous through the world and time

Down amidst his brazen walls

The accumulated Idol falls

To shapeless ashes; Demigod

Under the vulgar hoof down-trod

Whose neck he trod on; not an eye.

To weep his fall, nor lip to sigh

For him a prayer ; or, if there were,

No God to listen or reply.

The children have to pay for the sin of the father, and sire for the guilt of son :

Thus with old Priam, with his royal line,

Kindred and people; yea, the very towers

They crouch'd in, built by masonry divine. ${ }^{2}$ 
Then, at the thought of the home desolated by Helen's flight, the stately approval of the fateful doom upon crime and its abettors becomes a flood of pained sympathy with the injured:

Like a dream through sleep she glided

Through the silent city gate,

By a guilty Hermes guided

On the feather'd feet of Theft ;

Leaving between those she left

And those she fled to lighted discord,

Unextinguishable Hate ;

Leaving him whom least she should,

Menelaus brave and good,

Scarce believing in the mutter'd

Rumour, in the worse than utter'd

Omen of the wailing maidens,

Of the shaken hoary head :

Of deserted board and bed.

For the phantom of the lost one

Haunts him in the wonted places ;

Hall and Chamber, which he paces

Hither, Thither, listening, looking,

Phantom-like himself alone.

Till he comes to loathe the faces

Of the marble mute Colossi,

God-like Forms, and half-divine,

Founders of the Royal line,

Who with all unalter'd quiet

Witness all and make no sign.

But the silence of the chambers,

And the shaken hoary head,

And the voices of the mourning

Women, and of ocean wailing,

Over which with unavailing

Arms he reaches, as to hail

The phantom of a flying sail-

All but answer, Fled! fled! fled!

False! dishonour'd! worse than dead! 
Night at last ; he dreams ; and She

Once more in more than bridal beauty stands ;

But, ever as he reaches forth his hands,

Slips from them back into the viewless deep,

On those soft silent wings that walk the ways of sleep. ${ }^{3}$

The Rubáiyát, however, is that by which FitzGerald lives, and will live. It we have to search in order to discover the secret of his fame. The first feeling, when we have leisure to review impressions, is of surprise at our indifference to the question of the translator's fidelity. It is a matter of complete unimportance to us whether it be a translation at all. At the same time all of us, however absolutely ignorant of Persian, are confident that, if it be, it is perfect in spirit, 'divinely done,' 'a planet equal to the sun which cast it,' as Tennyson, much too flatteringly at any rate to Omar, sums it up. ${ }^{4}$ We are too entirely dominated by a consciousness of force, comprehensiveness, will, sufficiency, to be disposed to question an author's right to deal as with his own.

The mere language, in its elastic strength as of steel, seems to have been created to make a weapon of an agnosticism indistinguishable from dogmatism. Every fresh article in the indictment against one or another of the seventy-two emulous religions of the world strikes with the keenness of Sultan Saladin's sword. FitzGerald, though no follower in his own most simple regimen of Omar Khayyám's philosophy of the senses, was resolved to do his tenets justice. He is scrupulous to marshal them in all their heterodoxical effrontery, with a challenge to orthodoxy in any positive form to do better. The vigour with which the gauntlet is hurled is tremendous; and the defiance is set off with the utmost charms of rhythm. The texture is a model of poetic joinery. Everywhere, in every detail, 
the reader is aware of exact, infallible workmanship. The combination of measured uniformity in melody with an effect of continual variety is amazing. There is no staleness, no monotony. At the close of each stanza we are impatient for the next; we are wondering what new tone is to burst from the cell of the last. The ear listens eagerly for ebb and flow, which, scarcely expecting, it expects, craves, and rejoices to welcome back. As the Argument unwinds itself, the rhythm constantly envelops, adapts itself to, each successive evolution and convolution.

For the all but matchless stanzas, the seventeenth to the twentieth, the metre becomes as musically melancholy as if it had been devised for the mourning of Thammuz :

Whether at Naishápúr or Babylon,

Whether the cup with sweet or bitter run,

The Wine of life keeps oozing drop by drop,

The Leaves of life keep falling one by one.

Each Morn a thousand Roses brings, you say;

Yes, but where leaves the Rose of Yesterday?

And this first Summer month that brings the Rose

Shall take Jamshýd and Kaikobád away.

Then :

Think in this battered Caravanserai,

Whose Portals are alternate Night and Day,

How Sultan after Sultan with his Pomp

Abode his destined Hour, and went his way.

They say the Lion and the Lizard keep

The Courts where Jamshýd gloried and drank deep ;

And Bahrán, that great Hunter-the Wild Ass

Stamps o'er his Head, but cannot break his Sleep.

I sometimes think that never blows so red

The Rose as where some buried Caesar bled;

That every Hyacinth the Garden wears

Dropt in her lap from some once lovely Head. 
And this reviving Herb whose tender green Fledges the River-Lip on which we lean$\mathrm{Ah}$ ! lean upon it lightly ! for who knows From what once lovely Lip it springs unseen !

Ah, my Belovéd, fill the Cup that clears To-Day of past Regrets and Future Fears :

To-morrow. Why, To-morrow I may be Myself with Yesterday's Sev'n thousand years.

For some we loved, the loveliest and the best That from his Vintage rolling Time hath prest, Have drunk their Cup a Round or two before, And one by one crept silently to rest.

And we, that now make merry in the Room They left, and Summer dresses in new bloom,

Ourselves must we beneath the Couch of Earth

Descend-ourselves to make a Couch-for whom ${ }^{5}$

The Sage declares he had struggled against the conviction of the mortality of everything earthly :

Myself when young did eagerly frequent

Doctor and Saint, and heard great argument

About it and about; but evermore

Came out by the same door wherein I went.

With them the seed of Wisdom did I sow, And with mine own hand wrought to make it grow ;

And this was all the Harvest that I reap'd-

' I came like Water, and like Wind I go.' ${ }^{6}$

He had asked for evidence of the senses against the tragic conclusion; and in vain :

Strange, is it not ? that of the myriads who

Before us pass'd the door of Darkness through,

Not one returns to tell us of the Road,

Which to discover we must travel too. ${ }^{7}$

We are nothing, he concludes at last, but Shapes of Clay, and reason as would they in their Pottery, if endowed with speech : 
Said one among them-'Surely not in vain My substance of the common Earth was ta'en

And to this Figure moulded, to be broke, Or trampled back to shapeless Earth again.'

Then said a Second-' Ne'er a peevish Boy

Would break the Bowl from which he drank in joy;

And He that with His hand the Vessel mado

Will surely not in after Wrath destroy.'

After a momentary silence spake

Some Vessel of a more ungainly Make;

'They sneer at me for leaning all awry :

What! did the Hand then of the Potter shake?'

Whereat some one of the loquacious Lot-

I think a Sufi pipkin-waxing hot-

'All this of Pot and Potter-Tell me then,

Who is the Potter, pray, and who the Pot ?'

As they altercate on the meaning of existence for them, and their probable assignment to honour or dishonour, breakage or immortality, we seem to hear the whirring, whizzing of the potter's wheel beside them.

The breadth and grasp of thought, the Protean grace of the harmony, have their several shares in the fascination the handful of verse exerts. They solve only partially the problem of its astonishing degree, though the full answer will more or less include their co-operation as agents. It is the personality of the Man, a real Man, which alone fully explains the rank the poem has asserted for itself in literature, and, unfortunately, though, I am persuaded, without FitzGerald's intention, in society itself. A poet's own character is always a main condition of the place to be assigned to him. Here is no suspicion of personal unworthiness or weakness. We find a genuine Edward FitzGerald everywhere, except on the title-page ; and manly, adequate always, Real as were the versifiers 
we signify under the name of Omar Khayyám, they do not equal FitzGerald in realness for us. He is not the less real to us that in his lifetime the one quality he managed for the most part to hide was his genius. He moved in the narrowest of orbits, not disdaining intimacy with his posthumous father-in-law, the Quaker, banker, and poetaster, worthy Bernard Barton. Always he cared less for admiration than for affection, which he prized, while he seemed to slight. Few even of his familiars, perhaps not Tennyson himself, notwithstanding the dedication, could have guessed that he was secure of immortality on Parnassus.

For the world no man of letters could have been more obscure. Of the bulk of his doings in literature it remains serenely unconscious still. His anonymous version of Omar's reputed musings itself, it refused to take at his own final valuation of a penny piece. A quarter of a century after the original publication in 1859, the Encyclopaedia Britannica, in a list of editions of the Rubáiyát, refers to his as just ' a portion of the same rendered in English verse by $\mathrm{E}$. Fitzgerald '.9 The coldness of literary opinion, while he lived, struck his sense of humour rather than of resentment. It never occurred to him to complain. His interest was in his work for the time being-as much in a plodding verification of the Field of Naseby, as in the inspired interpretation of a 'golden Eastern lay'. ${ }^{10}$ So long as he felt he had done his part thoroughly, and to the best of his powers, he was sovereignly content.

So lived "Old Fritz"; and so he died; to have the minutest, half legendary, scrapings of his character lit up in the grave with a blaze of renown. Nor without reason, as I sincerely think; though I have been exposing myself, I know, to condemnation, alike, for exaggerated eulogizing 
of the verse, by persons never touched with the rapture of the Englished Rubáiyát as mere harmony, and by votaries of the doctrines, for having minimized their merits out of theological or moral bigotry.

Rubaiyát of Omar Khayyám, the Astronomer, Poet of Persia. Rendered into English Verse. Macmillan \& Co., 1900.

Agamemnon-A Tragedy: Taken from Aeschylus. Bernard Quaritch, 1876.

Letters and Literary Remains of Edward FitzGerald, ed. W.A. Wright, 1889.

${ }^{1}$ Bredfield Hall (Letters and Literary Remains), vol. iii, pp. 458-61.

2 Agamemnon, Chorus 4-5, pp. 13-15.

3 Ibid., Chorus 6-7, pp. 15-17.

- To E. Fitzgerald (Tiresias and Other Poems, 1885), p. 3.

- Rubayyát, stanzas 8-9 and 17-23, pp. 29-30 and 32-4.

- Ibid., stanzas 27-8, p. $36 . \quad$ Ibid., st. 64, p. 48.

- Ibid., stanzas 84-7, pp. 55-6.

- Encyc. Brit., ed. ix, vol. xviii, 1884. Art. Omar Khayyám (H.E.).

${ }^{10}$ Vide suprà, Tennyson to Fitzgerald (Tiresias, \&c.), p. 3. 


\section{COVENTRY PATMORE}

\section{$1823-1896$}

As I read Coventry Patmore, I wonder if there be not a secret religion among women of the middle and upper classes. Man would have no right to be surprised if they all kept in their boudoirs, their school-room desks, their wardrobes, along with Jane Eyre and The Christian Year, copies of The Angel in the House, Victories of Love, The Unknown Eros. Before they go down in the morning, while they dress for dinner, after or before their evening prayer, they might well find time for a few verses, if not for a book. May there not be ladies' clubs at which he is regularly studied, Girton Extension lectures at which he is expounded? When men praise their Milton, Wordsworth, Browning, Tennyson, do they never hear Patmore's name interpolated whisperingly by feminine lips ? True that he is seldom mentioned openly, and now less often than thirty years ago. It may merely be another proof of the adage that half of us know nothing of the way in which the other half live. I find it hard to credit that the one real poet who honestly believed in the right divine of women to be adored no less after than before marriage, and more so as wives than as brides, has ceased to be habitually revered by their sex. Poetesses do not count, besides that they rarely are genuine woman-lovers. Until Coventry Patmore poets had been wont to end their worship as soon as the Altar steps were reached. As he 
boasts, it was reserved for him, last of all, to sing the first of themes.

He traces it in a series of soft-sweet idylls, very fully from the wooing to the wedding-ring, and thence, in outline, rather shadowy, through happy years of nuptial and parental love. The husband-lover prays to be inspired as chronicler :

Thou, Primal Love, who grantest wings

And voices to the woodland birds,

Grant me the power of saying things

Too simple and too sweet for words. ${ }^{1}$

His verse sufficiently proves that his petition was received. With charming delicacy he describes the discovery, in Honoria Churchill, the player of

\section{The Wedding March of Mendelssohn, ${ }^{2}$}

of the girl with whom as a child he had played six years before; the revelation to himself of his passion through a passing tremor at the thought of a possible rival ; and its elevating effect :

Whatever in her sight I'd seem

I'd really be; I'd never blend

With my delight in her a dream

'Twould change her cheek to comprehend. ${ }^{3}$

Were his affection to be unreturned, he would be proud of it still :

If fate Love's dear ambition mar, And load his breast with hopeless pain, And seem to blot out sun and star, Love, lost or won, is countless gain ;

His sorrow boasts a secret bliss

Which sorrow of itself beguiles, And Love in tears too noble is

For pity, save of Love in smiles. ${ }^{4}$

For him it envelops the universe; casting, in the eyes voL. II 
of the sleepless watcher, uncertain as yet of the issue of his suit, a grim pallor at dawn over

The landscape, all made sharp and clear

By stillness, as a face by death. ${ }^{5}$

A little later : the blessed answer has been given; and the same landscape is transfigured:

'Twas when the spousal time of May

Hangs all the hedge with bridal wreaths, And air's so sweet the bosom gay

Gives thanks for every breath it breathes ;

That I, in whom the sweet time wrought,

Lay stretch'd within a lonely glade, Abandon'd to delicious thought

Beneath the softly twinkling shade. The leaves, all stirring, mimick'd well

A neighbouring rush of rivers cold, And, as the sun or shadow fell,

So these were green and those were gold;

In dim recesses hyacinths droop'd,

And breadths of primrose lit the air, Which, wandering through the woodland, stoop'd

And gather'd perfumes here and there;

Upon the spray the squirrel swung, And careless songsters, six or seven,

Sang lofty songs the leaves among,

Fit for their only listener, Heaven. ${ }^{6}$

If there could be a drawback to the wooer's own ecstasy, it was caused by its completeness :

She answering, own'd that she lov'd too.

The avowal had overwhelmed the victor with compassion, even shame, at his lady paramount's abdication of her throne :

By that consenting scared and shock'd,

Such change came o'er her mien and mood

That I felt startled and half mock'd

At winning what I had not woo'd. 
My queen was crouching at my side, By love unscepter'd and brought low, Her awful garb of maiden pride All melted into tears like snow. Her soul, which late I loved to invest With pity for my poor desert, Buried its face within my breast, Like a pet fawn by hunters hurt. ${ }^{7}$

My extracts will, I am afraid, have produced an impression that Coventry Patmore, like other minstrels of love, found, notwithstanding his protestations, a readier subject in the wooing than in wifehood. Whatever his design, that is true in fact of The Angel in the House; though even there lovely rays play over the

Sweet stranger, whom I called my wife;

Showing

How light the touches are that kiss

The music from the chords of life. ${ }^{8}$

But the recorder would have been false to his own plan and principle had he closed his history with the wedding, or even the honeymoon. Naturally he should have continued it to and within the poet-bridegroom's pleasant house of The Hurst. He chose instead-more the pity-to assign the leading matrimonial parts in Victories of Love to a cousin, and undeclared admirer, of the heroine of the earlier volume-Frederick Graham-and his wife Jane, whom he had married to deaden a tormenting memory and regret.

Though the second poem shares the general fate of sequels as a whole, it has excellencies of its own, and at all events was, in default of Honoria for sole heroine, a necessity. In The Angel in the House the wife was a goddess born. She remains, if in the background, a goddess in Victories of Love, with her husband for vowed and loyal worshipper. The other, with no adorer in her train, least of all, her 
bridegroom, first becomes beautified for him by maternity, as with penitent astonishment he avows :

When the new-made Mother smiled,

She seemed herself a little child, Dwelling at large beyond the law

By which, till then, I judged and saw, And that fond glow, which she felt stir

For it, suffused my heart for her ;

To whom, from the weak babe, and thence

To me, an influent innocence,

Happy, reparative of life,

Came, and she was indeed my wife, As there, lovely with love, she lay. ${ }^{9}$

It is a further stage when he discovers Jane, in the companionship of Honoria, the object of his early idolatry, transformed into a Divinity herself. One step still onward ; and wife's, mother's, goddess's love, that had never tired or fainted, turns back the current of time, devotion, and passion, to the steps of the marriage Altar itself; and, in the dead woman's written legacy of triumph,

Death, which takes me from his side,

Shows me, in very deed, his bride $!^{10}$

Alas, fond wretch !

We pass from gentlest simplicity in Victories of Love to the strangest of strange, wild labyrinths of fancy ministering to theology, in The Unknown Eros. Patmore's entreaty was far from granted if he were serious in beseeching Urania to inspire him with

Chants as of a lonely thrush's throat

At latest eve,

That does in each calm note

Both joy and grieve ;

Notes few and strong and fine,

Gilt with sweet day's decline,

And sad with promise of a different sun. ${ }^{11}$ 
But, in compensation, the whole is full of grand spasms of tragic emotion ; of enigmas, which I could not wish to be a thought, a throb, plainer. I am content with the beauty, if fevered, which is indisputable.

What a cry of protesting, unavailing anguish is the Departure!

It was not like your great and gracious ways!

Do you, that have nought other to lament,

Never, my Love, repent

Of how, that July afternoon,

You went,

With sudden, unintelligible phrase,

And frighten'd eye,

Upon your journey of so many days,

Without a single kiss, or a goodbye ?

I knew indeed that you were parting soon;

And so we sate, within the low sun's rays,

You whispering to me, for your voice was weak,

Your harrowing praise.

Well, it was well,

To hear you such things speak,

And I could tell

What made your eyes a growing gloom of love,

As a warm South-wind sombres a March grove.

And it was like your great and gracious ways

To turn your talk on daily things, my Dear,

Lifting the luminous, pathetic lash

To let the laughter flash,

Whilst I drew near,

Because you spoke so low that I could scarcely hear.

But all at once to leave me at the last,

More at the wonder than the loss aghast,

With huddled, unintelligible phrase,

And frighten'd eye,

And go your journey of all days

With not one kiss, or a goodbye,

And the only loveless look the look with which you pass'd ;

'Twas all unlike your great and gracious ways. ${ }^{12}$ 
If aught could be as pathetically, affectionately cruel as what I understand to have been the wife's plot to spare her husband the agony of a farewell on the brink of an open grave, it is his charge against the pitying dead that her loving mercy had been treason to love. His wakeful nights are harassed by recollections of his living Love's presentiments; by the bitter thought that he ought to have recognized in them a warning, however useless, of the impending blow :

'If I were dead, you'd sometimes say Poor Child!'

The dear lips quiver'd as they spake,

And the tears brake

From eyes which, not to grieve me, brightly smiled.

And did you think, when you so cried and smiled,

How I, in lonely nights, should lie awake,

And of those words your full avengers make?

Poor Child, poor Child ! ${ }^{13}$

Then, when he falls asleep, comes, to heighten, blacken, the grief of bereavement, a recurrent nightmare, in which

$I$, in a mortal sorrow, still pursue

Thro' sordid streets and lanes

And houses brown and bare

And many a haggard stair

Ochrous with ancient stains;

But ever, at the last, my way I win

To where, with perfectly sad patience nurst

By sorry comfort of assured worst,

Ingrain'd in fretted cheek and lips that pine,

On pallet poor

Thou lyest, stricken sick,

Beyond love's cure,

By all the world's neglect, but chiefly mine. ${ }^{14}$

And yet another dream-dream on dream-by the open window, outside which climbed an odorous azalea : 
Last night the delicate crests of saffron bloom

Were just at point to burst.

At dawn I dream'd, $O$ God, that she was dead,

And groaned aloud upon my wretched bed,

And waked, ah, God, and did not waken her,

But lay, with eyes still closed,

Perfectly bless'd in the delicious sphere

By which I knew so well that she was near,

My heart to speechless thankfulness composed.

Till 'gan to stir

A dizzy somewhat in my troubled head-

It was the azalea's breath, and she was dead!

The warm night had the lingering buds disclosed,

And I had fall'n asleep with to my breast

A chance-found letter press'd

In which she said,

'So till to-morrow eve, my Own, adieu !

Parting's well paid with soon again to meet

Soon in your arms to feel so small and sweet,

Sweet to myself that am so sweet to you !' ${ }^{15}$

With a fine instinct the half-orphaned, more than halforphaned, because motherless, child is introduced, to point the desolation of the home. The lonely boy's self-comforting is as painful as, in The Departure, Eurydice, and The Azalea, the father's heart-void :

My little Son, who look'd from thoughtful eyes And moved and spoke in quiet grown-up wise, Having my law the seventh time disobey'd,

I struck him, and dismiss'd

With hard words and unkiss'd,

His Mother, who was patient, being dead.

Then, fearing lest his grief should hinder sleep,

I visited his bed,

But found him slumbering deep,

With darken'd eyelids, and their lashes yet

From his late sobbing wet.

And I, with moan,

Kissing away his tears, left others of my own; 
For, on a table drawn beside his head,

He had put, within his reach,

A box of counters and a red-vein'd stone,

A piece of glass abraded by the beach

And six or seven shells,

A bottle with bluebells

And two French copper coins, ranged there with careful art, To comfort his sad heart.

So when that night I pray'd

To God, I wept, and said :

$\mathrm{Ah}$, when at last we lie with tranced breath,

Not vexing Thee in death,

And Thou rememberest of what toys

We made our joys,

How weakly understood, Thy great commanded good.

Thou, fatherly not less

Than I whom Thou hast moulded from the clay,

Thou']t leave Thy wrath, and say,

'I will be sorry for their childishness.' 16

The succession of The Unknown Eros to The Angel in the House, with its quiet, limpid grace, almost gaiety, and to the almost tameness of Victories of Love, is among the curiosities of poetical literature. I can discover no affinity between this and either of the earlier works, though all three share the same theme of conjugal affection. Did not the history of poetry furnish many examples of exotic growths in established reputations, it would be hard to understand the phenomenon. A bright reasonableness, amusing itself with passion, is the distinctive note of Coventry Patmore's previous love-dramas. His type of heroine never loses her balance-is such,

even at its brightest play,

That her mirth was like the sunshine in the closing of the day. ${ }^{17}$

In grief and adversity her emotions would have been as discreetly ordered; and in weal and woe the hero must 
have matched her. Never, not to speak of Jane and Frederick, could there be imagined personages less likely than Honoria and Felix Vaughan to toss to and fro the thunderbolts of Eros.

Yet here the thing is ; and it is a marvel. The wonder is not less than the species of madness, resulting, as in Tennyson's Maud, from the life's wreck, dissolves into a boiling rapture of Catholic mysticism. The series of politico-ecclesiastical rhapsodies has a floating, indefinable connexion with the preceding tempest of despair, and burns like that. Now and then there is a lull, a breath of simple tenderness; as in the delicious picture of the Virgin-Mother adoring at once Deity and Infancy :

All Mothers worship little feet, And kiss the very ground they've trod ;

But, ah, thy little Baby sweet

Who was indeed thy God! 18

In general, Patmore wanders, and deliberately, very far from his old 'crystal-flowing source ',19 following the light which

Shone from the solitary peak at Edgbaston..$^{20}$

Yet he remains a poet still, whose inspiration, though expressed in

a language dead, ${ }^{21}$

would, except for the controversial element, have been widely recognized in verse like the Deliciae Sapientiae de Amore, and Auras of Delight. $\mathrm{He}$ is always original, vivid and strong; so strong indeed that any who desire really to measure how high his fancy had in it to rise, must study, not so much The Angel in the House, as The Unknown Eros.

The Angel in the House, by Coventry Patmore. Third Edition London : John W. Parker, 1860. 
Poems by Coventry Patmore: vol. iii, Victories of Love; vol. iv, The Unknown Fros. George Bell \& Sons (no date).

The Unknown Eros, by Coventry Patmore. Third Edition. G. Bell \& Sons, 1890.

1 The Angel in the House: Preludes, 5, The Impossibility, p. 14.

Ibid., Cathedral Close, 2, p. 17

3 Ibid., The Morning Call, 3, p. 58.

- Ibid., Preludes, 2, p. 64.

- Ibid., Going to Church, 1, p. 128.

- Ibid., The Revulsion, 1, pp. 242-3.

Ibid., The Abdication, 5, pp. 158-9.

- Ibid., Husband and Wife, 1, p. 301.

- Victories of Love, From Frederick, p. 100.

${ }^{10}$ Ibid., From Jane to Mrs. Graham, pp. 166-7.

11 The Unknown Eros, Proem, pp. 7-8.

12 Ibid., 8, Departure, pp. 39-41.

13 Ibid., 14, 'If I were Dead,' pp. 62-3.

14 Ibid., 9, Eurydice, pp. 43-4.

15 Ibid., 7, The Azalea, pp. 37-8.

16 Ibid., 10, The Toys, pp. 46-8.

17 The Portrait (p. 139, Florilegium Amantis, ed. Rich. Garnett. G. Bell, 1879).

18 The Unknown Eros: Regina Cœli, p. 194 (Third Edition, 1890, one vol. G. Bell \& Sons).

19 Ibid., Proem, p. iv.

${ }^{20}$ Ibid., Book II, 4, The Standards, p. 120.

21 Ibid., Book II, 18, Dead Language, p. 210. 


\section{DAN'TE GABRIEL ROSSE'T'TI}

\section{$1828-1882$}

THERE are readers who like their poets unmixed-poets, not philanthropists or misanthropists, theologians or sceptics, metaphysicians or biologists, wits, satirists, humorists, as well. Rossetti was made to suit them. Just and noble sentiments adorn his verse. Its scenery could have been represented only by a painter of genius, a thoughtful observer of nature. Allusions continually testify to the student both of man and of books. The things are, however, where they are solely to serve the demands of the poet's art. He is poet in every line, every turn of a phrase, in the modelling of every cadence. In a piece of a hundred and eighty stanzas I find but one which is prosaic. He might have seemed of a nature too finely constituted, too subtle, too exclusive, for a ballad writer. Whatever instinct, perhaps weariness of the sole companionship of his own emotions, the craving for an appeal to wider sympathies, turned his Muse in that direction, as poet he accepted freely its obligations. Being the thorough artist he was, the most fastidious of writers became plain, rough, and brusque ; the faultlessly metrical versifier stumbled in half rhymes. It can plainly be discerned that the uncouthness, the irregularities, are as intentional as they are popularly effective. I believe that the White Ship, the King's Tragedy, weird Rose Mary itself-Beryl Songs and all-would at a Penny Reading be sure of cheers and tears, even of comprehension, if partial, from the humblest audience. 
The Three rank among the foremost of their class in English verse; and they are the work of one of the most naturally aesthetic of poets. It is interesting to trace how, under cover of a story fitted to captivate a peasant, a mechanic, a child, as dainty a web of thought and feeling is worked in each as could have been spun for a study in psychology. Lawless licence is duly chastised in Knight and damsel, but as the climax of a most intricate game of cross purposes. Out of a mother's beautiful pride in a daughter's imagined purity :

Mary mine that art Mary's rose,

is hammered an engine at once to pierce the guilty heart, and to slay its betrayer. The lover who would have lived if loyal, dies for his faithlessness. The Beryl-stone itself, in all its brilliancy, perishes for its perfidious complicity with devils.

The magical jewel reflected the future in its gleaming depths, but to none but a pure maid. It had been read by the girl in her childhood. She was to read it now, at her mother's dictate, to learn on which road an ambush might be laid to take the life of her affianced lover, Sir James of Heronhaye, as he rode to be shriven at Holy Cross. She dared not tell her mother that she fulfilled the fated condition no longer :

Pale Rose Mary sank to the floor :-

'The night will come if the day is o'er!'

'Nay, heaven takes counsel, star with star, And help shall reach your heart from afar :

A bride you'll be, as a maid you are.'

The lady unbound her jewelled zone And drew from her robe the Beryl-stone.

Shaped it was to a shadowy sphere,World of our world, the sun's compeer, That bears and buries the toiling year. 
With shuddering light 'twas stirred and strewn

Like the cloud-nest of the wading moon;

Freaked it was as the bubble's ball,

Rainbow-hued through a misty pall,

Like the middle light of the waterfall.

The lady upheld the wondrous thing:-

'Ill fare,' she said, ' with \& fiend's fairing

But Moslem blood poured out like wine

Can hallow Hell 'neath the Sacred Sign;

And my lord brought this from Palestine.

Spirits who fear the Blessed Rood

Drove forth the accursed multitude

That heathen worship housed therein,-

Never again such home to win,

Save only by a Christian's sin.'

Low spake maiden Rose Mary :-

' $O$ mother mine, if I should not see!'

'Nay, daughter, cover your face no more,

But bend love's heart to the hidden lore,

And you shall see now as heretofore.' 1

She gazes, and perceives by the broken water-gate armed men, as watching for their prey, with the Warden of Holycleugh, Sir James's sworn foe, at their head. All elsewhere is clear, except that of seven hill-clefts on the road to Holycleugh's castle-steep, the seventh is 'brimmed with mist' :

' Small hope, my girl, for a helm to hide In mists that cling to a wild moorside : Soon they melt with the wind and sun, And scarce would wait such deeds to be done : God send their snares be the worst to shun.' 2

The vision had passed; and, as the mother, content, wrapped the stone close in her silken robe,

a music rained through the room:

Low it splashed like a sweet star-spray,

And sobbed like tears at the heart of May,

And died as laughter dies away. ${ }^{8}$ 
The knight was warned, and shunned the road by the watergate-yet he died :

' Daughter, daughter, remember you

That cloud in the hills by Holycleugh ?

'Twas a Hell-screen hiding truth away:

There, not i' the vale, the ambush lay,

And thence was the dead borne home to-day.' 4

The perjured dead! who was secretly pledged to the Warden's sister of Holycleugh, and had been on his way to concert his near marriage with her, when her wrathful brother waylaid him in the misty neighbouring hollow, and avenged both himself and Rose Mary! The whole is an example, worked out with extraordinary subtlety, of poetical, which happens to be coincident with moral, justice.

The White Ship, again, at first sight simply a straightforward chronicle of a national disaster, has its especial motive, an inner core of pathos. Without the two spiritual incidents of the Prince's affection, and the Pilot's refusal of life, I do not suppose it would have had Rossetti for chronicler :

A song,-nay, a shriek that rent the sky, That leaped o'er the deep !- the grievous cry Of three hundred living that now must die. An instant shriek that sprang to the shock As the ship's keel felt the sunken rock.

A moment the pilot's senses spin,-

The next he snatched the Prince 'mid the din,

Cut the boat loose, and the youth leaped in.

Out of the churn of the choking ship,

Which the gulf grapples and the waves strip, They struck with the strained oars' flash and dip.

'Twas then o'er the splitting bulwarks' brim The Prince's sister screamed to him. 
He knew her face, and he heard her cry, And he said, 'Put back ! she must not die !'

And back with the current's force they reel Like a leaf that's drawn to a water-wheel.

Low the poor ship leaned on the tide :

O'er the naked keel as she best might glide, The sister toiled to the brother's side.

He reached an oar to her from below, And stiffened his arms to clutch her so.

But now from the ship some spied the boat, And 'Saved!' was the cry from many a throat.

And down to the boat they leaped and fell :

It turned as a bucket turns in a well, And nothing was there but the surge and swell.

The Prince that was and the King to come, There in an instant gone to his doom.

He was a Prince of lust and pride ; He showed no grace till the hour he died.

When he should be king, he oft would vow, He'd yoke the peasant to his own plough. O'er him the ships score their furrows now.

God only knows where his soul did wake, But I saw him die for his sister's sake. ${ }^{5}$

To the mainyard, rent from the mast, two, Berold, the butcher's son of Rouen, and Godefroy de l'Aigle, were clinging, when

lo ! a third man rose o'er the wave, And we said, 'Thank God! us three may He save !'

He clutched to the yard with panting stare, And we looked and knew Fitz-Stephen there.

He clung, and 'What of the Prince ?' quoth he. 'Lost, lost !' we cried. He cried, 'Woe on me!' And loosed his hold, and sank through the sea. ${ }^{6}$ 
I do not venture to require, as a right, of The King's 'Tragedy any explanation of its choice other than the splendour of the hideous tale itself. We feel the awe of the suspense, before the assassins had returned for a further search after the king's hiding-place to the room tenanted now only by heroic Catherine Douglas, helpless from the torture of her shattered arm :

Through the open door

The night-wind wailed round the empty room

And the rushes shook on the floor.

And the bed drooped low in the dark recess

Whence the arras was rent away;

And the firelight still shone over the space

Where our hidden secret lay.

And the rain had ceased, and the moonbeams lit

The window high in the wall,-

Bright beams that on the plank that I knew

Through the painted pane did fall

And gleamed with the splendour of Scotland's crown

And shield armorial.

But then a great wind swept up tne skies,

And the climbing moon fell back;

And the royal blazon fled from the floor,

And nought remained on its track ;

And high in the darkened window-pane

The shield and the crown were black. ${ }^{7}$

The horror of the murder-scene is depicted with the merciless fidelity of an artist's eye. Even in bloodier-red glares the fury of sweet Queen Jane against the assassins of her unburied husband :

The month of March wore on apace;

And now fresh couriers fared

Still from the country of the Wild Scots

With news of the traitors snared. 
And evermore as I brought her word,

She bent to her dead king James,

And in the cold ear with fire-drawn breath

She spoke the traitors' names.

But when the name of Sir Robert Graeme

Was the one she had to give,

I ran to hold her up from the floor ;

For the froth was on her lips, and sore

I feared that she could not live.

And now of their dooms dread tidings came,

And of torments fierce and dire ;

And nought she spake,-she had ceased to speak,-

But her eyes were a soul of fire.

But when I told her the bitter end

Of the stern and just award,

She leaned o'er the bier, and thrice three times

She kissed the lips of her lord.

And then she said,- ' My King, they are dead!'

And she knelt on the chapel floor, And whispered low with a strange proud smile,

'James, James, they suffered more!' 8

It was the triumph of her vengeance; and the poet seems to share it. Yet I suspect that he had been thinking more of the singer of the King's Quair than of the crowned reformer of wrong, the administrator of even justice to high and low; less of the Avenger of treason against her royal consort than of her who from the time when first she was wedded, oft would sigh :

'To be born a king!'

And oft along the way

When she saw the homely lovers pass,

She has said, 'alack the day !' 9

whose farewell cry over her slain husband-lover was :

vol. II 
'Alas for the woful thing,

That a poet true and a friend of man,

In desperate days of bale and ban,

Should needs be born a king!' 10

Meanwhile, alike here, and in Rose Mary and The White Ship, far apart as may be the theme's secret attraction for the writer, all the time on has swung the action, bleak, and bold, and bare, to the inevitable catastrophe !

A nature, like Rossetti's, given to, almost made up of, moods, could scarcely have been expected to take to the composition of ballads. Having happened to invest himself with the minstrel's harp and mantle, he was bound to invent occasions for the exercise of his delicate fancy. The sonnet was a much more natural vehicle for the play of his imagination; and he needed no excuses there. It is no point of honour of a sonnet to be popular; and his sonnets certainly are not. A sonnetwriter commonly does not write under a sudden impulse. He does not sing because he must. Deliberately, almost in cold blood, he sits down to his lace-work. His productions are addressed to a limited circle ; often in appearance, though less often in fact, to an individual ; seldom, if ever, to the public. Some spiritual force, doubtless, though not operating directly, has worked upon him to versify after this kind. For it, necessarily, inspiration is wanted no less than art. Imperative as are the laws of the sonnet, it needs, in order to be tolerable, and perhaps more urgently than other departments of poetry, real poetic fire. Nothing is more odiously dreary than a sonnet perfect in form which is not a poem in spirit. The glory of Rossetti's sonnets is that all have the glow of feeling in them, and that, in several, it is the essence. They observe the rigid precision of standard 
rose-trees in their outline, and burst above into a soft shower of odorous bloom.

Sonnet-building was in his blood. The rapture of Danteworship constituted it his profession. From his models in the Vita Nuova, and the cycle of the Master's harbingers and companions, he learnt how to extract the utmost music from the jangling of the curious under-vesture of shackles. His inimitable translations show his skill. Particularly admirable in his original work is the series he entitled The House of Life. In it, with a hand comparatively free, he constructs, brick by brick, to be overlaid with a marble coating, a temple of Love. I confess the marvel of the masonry; in each segment the interdependence at once, and independence, with final unity. Over and above all blows an air of refreshing spontaneity. They to whom the rigours of the metre, especially in a chain with a hundred links, are distasteful, should yet overcome their prejudice sufficiently to give The House of Life a fair trial. They would, I think, acknowledge that it has proved it possible, if by no means a thing of course, for a sonnet to be a poem also.

Unfair as it may be to tear away members of the series, I am compelled by the laws of space to offer specimens only. None will dispute the beauty of Youth's SpringTribute :

On this sweet bank your head thrice sweet and dear

I lay, and spread your hair on either side,

And see the newborn wood flowers bashful-eyed

Look through the golden tresses here and there.

On these debateable borders of the year

Spring's foot half falters; scarce she yet may know

The leafless blackthorn blossom from the snow;

And through her bowers the wind's way still is clear. 
But April's sun strikes down the glades to-day ;

So shut your eyes upturned, and feel my kiss

Creep, as the Spring now thrills through every spray,

Up your warm throat to your warm lips; for this

Is even the hour of Love's sworn suit-service,

With whom cold hearts are counted cast-away. ${ }^{11}$

Add, for the contrast of a more serious note, Lost Days :

The lost days of my life until to-day,

What were they, could I see them on the street

Lie as they fell ? Would they be ears of wheat

Sown once for food but trodden into clay?

Or golden coins squandered and still to pay?

Or drops of blood dabbling the guilty feet?

Or such spilt water as in dreams must cheat

The undying throats of Hell, athirst alway?

I do not see them here; but after death

God knows I know the faces I shall see, Each one a murdered self, with low last breath:

'I am thyself,-what hast thou done to me ?'

'And I-and I-thyself,'-lo! each one saith,-

'And thou thyself to all eternity!' 12

The volume of Ballads and Sonnets contains little or nothing imperfect. The rest of the general collection of poems is not liable to that somewhat invidious praise. Among its contents are pieces beautiful only to a few of whom I myself am not one-and there are pieces which must, I should suppose, be beautiful to all ; for example, the lines, Sudden Light, on that phase of second sight which shadows the past from the present :

I have been here before, But when or how I cannot tell;

I know the grass beyond the door, The sweet keen smell,

The sighing sound, the lights around the shore. 
You have been mine before,-

How long ago I may not know ;

But just when at that swallow's soar

Your neck turned so,

Some veil did fall,-I knew it all of yore.

Has this been thus before?

And shall not thus time's eddying flight

Still with our lives our love restore

In death's despite,

And day and night yield one delight once more ? ${ }^{13}$

Lovelier still is The Portrait; and not the less lovely that it is the single eminent exception to the rule which governs, in my opinion, all Rossetti's poetical work :

This is her portrait as she was:

It seems a thing to wonder on,

As though mine image in the glass

Should tarry when myself am gone.

I gaze until she seems to stir,-

Until mine eyes almost aver

That now, even now, the sweet lips part

To breathe the words of the sweet heart :-

And yet the earth is over her.

In painting her I shrined her face

'Mid mystic trees, where light falls in

Hardly at all ; a covert place

Where you might think to find a din

Of doubtful talk, and a live flame

Wandering, and many a shape whose name

Not itself knoweth, and old dew,

And your own footsteps meeting you,

And all things going as they came.

A deep dim wood; and there she stands

As in that wood that day: for so

Was the still movement of her hands

And such the pure line's gracious flow. 
And passing fair the type must seem, Unknown the presence and the dream. 'Tis she : though of herself, alas !

Less than her shadow on the grass Or than her image in the stream.

Next day the memories of these things, Like leaves through which a bird has flown, Still vibrated with Love's warm wings ;

Till I must make them all my own And paint this picture. So, 'twixt ease Of talk and sweet long silences,

She stood among the plants in bloom

At windows of a summer room, To feign the shadow of the trees.

Last night at last I could have slept, And yet delayed my sleep till dawn, Still wandering. Then it was I wept ;

For unawares I came upon

Those glades where once she walked with me; And as I stood there suddenly,

All wan with traversing the night,

Upon the desolate verge of light

Yearned loud the iron-bosomed sea.

Even so, where Heaven holds breath and hears

The beating heart of Love's own breast,Where round the secret of all spheres

All angels lay their wings to rest,-

How shall my soul stand rapt and awed, When, by the new birth borne abroad

Throughout the music of the suns,

It enters in her soul at once And knows the silence there for God !

Here with her face doth memory sit

Meanwhile, and waits the day's decline, Till other eyes shall look from it,

Eyes of the spirit's Palestine, 
Even than the old gaze tenderer:

While hopes and aims long lost with her

Stand round her image side by side,

Like tombs of pilgrims that have died

A bout the Holy Sepulchre. ${ }^{14}$

Exquisite as is the beauty, the tenderness is as remarkable; and, for Rossetti, it is unique. It makes The Portrait exceptional, as I have said, in the body of his verse; and it is an exception which proves the rule. For elsewhere, alike where to me is the scent of violets, and to me the scent of poppies, I observe throughout one same quality in him. It connects all his many characteristics. It testifies to the empire over him of one literary canon and gospel. From old memories I enunciated it when I started. And now that I close the review of my more recent impressions of his poems I find my belief confirmed. More than Shelley-who was a priest of humanity as well as singermore even than Keats-in whom the distinct current of youth's warm blood, unchilled by the shadow of death, is perceptible-the rule with Rossetti is to be never other than a poet. While he recognizes in existence the requirements of other impulses, aims, and conditions-while he makes use of them himself-he never forgets, or pretends to forget, that for him their main object is to serve as poetic material. He shrinks from no sadness, sourness, ugliness, which will widen the compass of his lyre. I do not suppose I am libelling the general educated public if $I$ find in that imperious eclecticism, or aestheticism, a key to his lack at all times of common popular favour. I cannot affect to be surprised when I recollect some of his beautiful monstrosities. After all, it is not an unwholesome instinct which demands of the poetic art that it shall be life's minister, sanctifying, purifying, and sweetening. Rossetti the poet 
recognized no such obligation any more than Rossetti the painter. Accordingly, the poet, like the painter, probably will continue to be worshipped by a sect, and not by a nation.

However, poetry is a Kingdom with its own laws. It neither is obliged, nor desires, to be exclusive. Its borders are wide. They have made room for Dryden as for Milton, for Burns as for Cowper, for Byron as for Wordsworth. Well can they contain Rossetti also. Poems too have a being as well as the poet; and, so long as the language lasts, there are many of his which deserve always to be read, and some which will be.

The Poetical Works of Dante Gabriel Rossetti, ed. by W. M. Rossetti. One vol. Ellis \& Elvey, 1891.

(Ballads and Sonnets, by Dante Gabriel Rossetti. Fourth Edition. Ellis \& White, 1882.)

(The Early Italian Poets, A.D. 1100-1200-1300. Together with Dante's Vita Nuova, translated by D. G. Rossetti. Smith, Elder \& Co., 1861.)

1 Rose Mary, Part I, p. 105.

- Ibid., Part II, p. 117.

- Ibid., p. 144.

3 Ibid., p. 110.

s Ibid., p. 111

- The White Ship, pp. 140-5.

8 Ibid., pp. 173-4.

The King's Tragedy, pp. 168-9.

11 Youth's Spring Tribute (The House of Life-a Sonnet Sequence), No. 14, p. 183.

12 Lost Joys (Ibid.), No. 86, p. 220.

18 Sudden Light, p. 295.

14 The Portrait, stanzas 1, 3, 4, 7, 10, 11, 12, pp. 240-3. 


\section{WILLIAM MORRIS}

\section{$1834-1896$}

TAKe from the shelf a book by William Morris, new or old to you ; read or re-read in it ; and you will be very unwilling to put it down. The field is wide. The volume may be the wondrous quest of the Golden Fleece; the narrative enchants as if Orpheus again were the musician. A saga of the Volsungs may have furnished the theme ; and you find charm in a riot of perfidy and slaughter. Or it may be a story from the mythology of Greece; of Perseus, Psyche, Alcestis, Pygmalion, Bellerophon. Yet another volume; and you are arbitrating between fallen Guinevere and her accuser, Sir Gauwaine ; sitting with Launcelot, and his remorse, beside King Arthur's tomb ; or watching with pure Sir Galahad for the Sangreal. Valiant deeds are described, and shameful or heroic dooms, of Gascon knights and Gascon thieves; torturing options between some sudden end to gay, glorious life, and its continuance with dishonour. The whole wide area of fancy, history, fable, Morris claims for his own, wherever his genius divines a possibility of foothold. Anywhere and everywhere he roofs-in a house, lighting a fire on the hearth to prove his title. There you too have been at home with him. You pass out, and forget his existence. It is a riddle very hard to guess why the reader who has gladly warmed his hands by the blaze, so rarely comes back ; why, after having given apparently so much of himself to the poet, he carries little or nothing of the poet away. 
This is not the manner in which we treat, not merely the leaders of the choir of poets, Shakespeare, Milton, Dryden, Pope, Burns, Wordsworth, Byron, Shelley, Browning, Tenny: son, but others, like Gray, Goldsmith, Campbell. They are always with us. We have not to hunt for them. They come to meet us ; they seek for us. The reason is that they were born winged, and fly. Morris's stories and ballads, though not wingless, stay by the nest. They cannot live without their native air and earth about them. The special message which he, like other poets, ordained prophets and preachers, had to deliver, was not itself, like many of theirs, of a nature to circulate, vibrating and echoing. His was a gospel of beauty, as was Keats's ; only, Keats cared to dwell, almost to look, on nothing which was not in itself a thing of beauty. Morris saw beauty in everything, and was chained to that he saw by its very bulk. A massacre of Volsungs by Goths, for the Titanic magnitude of the treachery, rejoiced his Muse hardly less than the cruel daring which avenged it. The adultery of a hero's consort and his friend, treason, contrition, ecstasies of piety itself, and abiding heat of love purpled by the crime, painted his canvas with colours as precious to him as the virgin moonlight of Galahad's pilgrimage.

Mark how he revels in the rich medley of the guilty Queen's remorse and longing, as she kneels before the Blessed Rood :

' Unless you pardon, what shall I do, Lord, But go to hell ? and there see day by day Foul deed on deed, hear foulest word on word,

For ever and for ever, such as on the way

To Camelot I heard once from a churl

That curled me up upon my jennet's neck

With bitter shame; how then, Lord, should I curl

For ages and for ages? dost thou reck 
That I am beautiful, Lord, even as you And your dear mother? why did I forget You were so beautiful, and good, and true, That you loved me so, Guenevere ? O yet

If even I go to hell, I cannot choose But love you, Christ, yea, though I cannot keep From loving Launcelot; O Christ, must I lose

My own heart's love? see, though I cannot weep,

Yet am I very sorry for my sin ;

Moreover, Christ, I cannot bear that hell ;

I am most fain to love you, and to win

A place in heaven some time-I cannot tell-

Speak to me, Christ ! I kiss, kiss, kiss your feet;

Ah ! now I weep !'-The maid said, 'By the tomb He waiteth for you, lady,' coming fleet,

Not knowing what woe filled up all the room. ${ }^{1}$

He found food for sympathy and delight alike in the dauntless adventurousness of the Argonauts, in Medea's fratricide and lies, and in Jason's ungrateful infidelity. Opportunities were waiting everywhere to reward his insight and industry, whether in reconstructions of a savage feudalism, or in visions of democratic Gardens of Eden to be dotted about the happy wilds of re-afforested repentant Bloomsbury. Nay, his romance upholstered straightlegged chairs scattered here and there beside pomegranate wall-papers. All appealed to his instinct for picturesque variety, his horror of earthiness and monotony. Hestamped himself, his tastes and distastes, visibly and tangibly, on cottages and palaces by the thousand or ten thousand. Spiritually he was audible in volume after volume of admirable verse and prose. Unlike his poet-peers, he did not absorb his subject into himself ; rather, he sought to incorporate himself into it. His aim was to suffuse history and life with the atmosphere of lovely possibilities he 
discovered in them. He desired to inspire and invigorate by describing both as he saw them. Strangely enough, the result is not the robust picture of actualities which he may be presumed to have contemplated. Each successive scene floats in a haze of dreamy sunshine, through which the uproar and storm of human passion sound as melodiously unreal to the reader as the echo of past labours to the lotuseating sailors. Ever in vain the poet raises his protesting battle-cry of the tale he has

to tell,

Of the wonderful days a-coming, when all

Shall be better than well. ${ }^{2}$

Never was Muse readier to re-settle Past, Present, and Future. A chief bar to her success in attracting colonists is the requisition she makes upon them of abundant leisure and patience. There are tricks of style which become with repetition trying in the extreme. Such are the habit of inveterate refrains, and a pervading varnish of melancholy which an invariable sweetness does anything but relieve. But, above all, diffuseness is carried to an extent which pays no regard to the brevity of human life. It is the more vexatious that Morris occasionally indicates how he can present a scene in a way to make one catch one's breath. His besetting vice in another shape causes him to steep legends of prehistoric Greece, Norman Sicily, Scandinavian folklore, in one same ointment, fragrant and delightful in itself, but almost repulsive when found to be neither individual, nor native.

Yet even so-what a spirit the age lost when he died! How utterances of his with all their faults dwell on any memory which has once taken hold of them! It may be a mere exercise in rhythm, like Two Red Roses across the Moon. I read the crazy ballad the other day; and the 
feeling with which I had heard it recited by an Oxford friend, shortly after its publication, at once came back. The jingle of it had stayed with me unforgotten for fifty years, and unforgettable :

There was a lady lived in a hall,

Large in the eyes, and slim and tall ;

And ever she sung from noon to noon

'Two red roses across the moon.'

There was a Knight came riding by

In early spring, when the roads were dry ;

And he heard that lady sing at the noon,

'Two red roses across the moon.'

Yet none the more he stopp'd at all,

But he rode a-gallop past the hall ;

And left that lady singing at noon,

' Two red roses across the moon.'

Because, forsooth, the battle was set, And the scarlet and blue had got to be met, He rode on the spur till the next warm noon ;-

' Two red roses across the moon.'

That was the battle-cry he raised; and before it and his gold armour down went the scarlet and blue. Returning as victor, this time he halts at the hall and the lady :

Under the may she stoop'd to the crown, All was gold, there was nothing of brown; And the horns blew up in the hall at noon, 'Two red roses across the moon.' 3

In higher sorts there is, for example, the resolve of Volsung Signy to die Queen still of the abhorred Goths, in the flames of racial vengeance upon them, which she had herself caused to be kindled in her Goth Consort's palace. The strange evidence of fidelity to the letter of the bond she was betraying must not be permitted to founder 
along with its grand but water-logged epic. She had planned the destruction, and had come forth to exult with her brother Sigmund and her son Sinfiotli, in its completeness, but insisted on returning :

'My youth was happy; but this hour belike is best Of all the days of my life-tide, that soon shall have an end.

I have come to greet thee, Sigmund, then back again must I wend, For his bed the Goth-King dighteth ; I have lain therein time was.'And indeed as the word she uttereth, high up the red flames flare To the nether floor of the heavens; and yet men see them there, The golden roofs of Siggeir, the hall of the silver door That the Goths and the Gods had builded to last for ever more. She said: 'Farewell, my brother, for the earls my candles light, And I must wend me bedward, lest I lose the flower of night.' And soft and sweet she kissed him, ere she turned about again, And a little while was Signy beheld of the eyes of men;

And as she crossed the threshold, day brightened at her back, Nor once did she turn her earthward from the reek and the whirling rack,

But fair in the fashion of Queens passed on to the heart of the hall. And then King Siggeir's roof-tree upheaved for its utmost fall, And its huge walls clashed together, and its mean and lowly things The fire of death confounded with the tokens of the Kings. ${ }^{4}$

Morris delights, even more than other poets, in setting riddles; and many of his are worth guessing, as, for example, A Garden by the Sea :

I know a little garden-close,

Set thick with lily and red rose,

Where I would wander if I might

From dewy morn to dewy night,

And have one with me wandering.

And though within it no birds sing,

And though no pillared house is there,

And though the apple-boughs are bare

Of fruit and blossom, would to God

Her feet upon the green grass trod,

And I beheld them as before. 
There comes a murmur from the shore,

And in the close two fair streams are,

Drawn from the purple hills afar,

Drawn down into the restless sea;

Dark hills whose heath-bloom feeds on bee,

Dark shore no ship has ever seen,

Tormented by the billows green

Whose murmur comes unceasingly

Unto the place for which I cry.

For which I cry both day and night,

For which I let slip all delight,

Whereby I grow both deaf and blind,

Careless to win, unskilled to find,

And quick to lose what all men seek.

Yet tottering as I am and weak,

Still have I left a little breath

To seek within the jaws of death

An entrance to that happy place,

To seek the unforgotten face,

Once seen, once kissed, once reft from me Anigh the murmuring of the sea. ${ }^{5}$

He has, with the poet's gift of mystery, the poet's secret of charm. Both are present in Gunnar's Howe Above the House at Lithend. ${ }^{6}$ Both, with a deep thought too, underlie, in Mother and Son, a woman's confidences to her infant; spoken that he may imbibe in his spirit what she yearns that he should know, but would blush to tell him when old enough to understand, and, after all, leaves unsaid -perhaps, has not courage to say aloud to herself :

Now sleeps the land of houses, And dead night holds the street, And there thou liest my baby And sleepest soft and sweet. Lo amidst London I lift thee, And how little and light thou art, And thou without hope or fear, Thou fear and hope of my heart ! 
Lo here thy body beginning, $O$ son, and thy soul and thy life ; But how will it be if thou livest, And enterest into the strife, And in love we dwell together When the man is grown in thee, When thy sweet speech I shall hearken, And yet 'twixt thee and me Shall rise that wall of distance, That round each one doth grow, And maketh it hard and bitter, Each other's thought to know.

Now, therefore, while yet thou art little And hast no thought of thine own, I will tell thee a word of the world; Of the hope whence thou hast grown; Of the love that once begat thee, Of the sorrow that hath made Thy little heart of hunger, And thy hands on my bosom laid. Then mayst thou remember hereafter, As whiles when people say All this hath happened before In the life of another day; So mayst thou dimly remember This tale of thy mother's voice, As oft in the calm of dawning I have heard the birds rejoice, As oft I have heard the storm-wind Go moaning through the wood: And I knew that earth was speaking, And the mother's voice was good. ${ }^{7}$

Full of delicategrace, again, is the Praise of My Lady, which the shy lover, like the Mother, dares utter only to the air :

My lady seems of ivory

Forehead, straight nose, and cheeks that be

Hollow'd a little mournfully. Beata mea Domina! 
Her forehead, over-shadow'd much By bows of hair, has a wave such As God was good to make for me.

Not greatly long my lady's hair, Nor yet with yellow colour fair, But thick and crisped wonderfully.

Beneath her brows the lids fall slow, The lashes a clear shadow throw Where I would wish my lips to be.

I wonder if the lashes long Are those that do her bright eyes wrong For always half tears seem to be

Lurking below the underlid, Darkening the place where they lie hidIf they should rise and flow for me !

Her full lips being made to kiss, Curl'd up and pensive each one is ; This makes me faint to stand and see.

Nay, hold thy peace! for who can tell ? But this at least $I$ know full well, Her lips are parted longingly,

So passionate and swift to move,

To pluck at any flying love, That I grow faint to stand and see.

Yea! there beneath them is her chin, So fine and round, it were a sin

To feel no weaker when I see

God's dealings ; for with so much care And troublous, faint lines wrought in there, He finishes her face for me.

All men that see her any time, I charge you straightly in this rhyme, What, and wherever you may be, 
To kneel before her; as for me, I choke and grow quite faint to see My lady moving graciously,

Beata mea Domina ! 8

But Morris's distinctive strength is that of a storyteller. In a succession of massive volumes-the Life and Death of Jason, and The Earthly Paradise-he revealed even to scholars the wealth of romance imbedded in Greek myths and traditions. With a success as surprising he assimilated the Scandinavian spirit for the purpose of dealing with Scandinavian lore. The Defence of Guenevere, and, yet more, King Arthur's Tomb, need not shun comparison with Tennyson's treatment of the Arthurian legend. In isolated ballads on the borderland of history he stands in the first rank among his contemporaries.

As a minstrel he has two manners of relating a tale, and is a master in each. Of set purpose he spins a web for the entanglement of wits in the story of Rapunzel. After the same method the stir and rush of the Haystack in the Floods leave as much to be guessed as is told. Was this to be the end of the dreary flight, from the Chatelet, of Jehane the brown, the beautiful, the reputed witch, attended by her knightly lover; with her other lover, accuser, and witch-catcher, in hot pursuit?-

Had she come all the way for this,

To part at last without a kiss ?

Yea, had she borne the dirt and rain

That her own eyes might see him slain

Beside the haystack in the floods ? ${ }^{9}$

Or, following his larger way, he will, now, in hundreds of pages tell the tale of the Golden Fleece, or, now, in half a dozen, concerning the King of Denmark's Sons, recount how it all came about : 
And Harald reigned and went his way,

'So fair upriseth the rise of the sun.'

And still is the story told to-day,

'So grey is the sea when day is done.' 10

Histories, legends, songs, philosophies, moralities-they constitute together a vast total, with an astonishing evenness of merit. The several components are, one and all, interesting, and, not seldom, fascinating. Where then is their place in English poetry ? My object throughout my rapid review of our Poets has been to determine which of them are among the Immortals-which of them have left us heirs of possessions we cannot do without. Poems of such sort are at once necessaries and treasures ; and I have coveted the multiplication of them. When I began my sketch of William Morris, I intimated a fear that his work was not of the kind ; and this continues to be my impression. Much in it charms me whenever it places itself under my eyes. I do not long to return to it. A divine spark is wanting. It is not that a star has been hidden in a cellar, as the old poet imagined. Such as it is, it has been visible enough. Its orbit has been half a century of energetic modern life. Somehow, I suppose, Morris had to choose between the exercise of a single power, and divers; and he preferred many to much.

The Defence of Guenevere and Other Poems, by William Morris. Ellis \& White, 1858. Reprint from Edition, 1858 : Longmans, 1896.

The Story of Sigurd the Volsung, and the Fall of the Niblungs, by William Morris. Ellis \& White, 1877. New edition, Longmans, 1896.

Poems by the Way, And-Love is Enough, by William Morris. New Impression. Longmens, 1902.

1 King Arthur's Tomb (Defence of Guenevere, \&c.), pp. 29-30.

2 The Day is coming (Poems by the Way), p. 124.

3 Two Red Roses across the Moon (Defence of Guenevere), pp. 223-5.

- Sigurd the Volsung, Book I, pp. 52-3. 
- A Garden by the Sea (Poems by the Way), pp. 79-80.

- Gunnar's Howe above the House at Lithend_(ibid.), pp. 122-3.

7 Mother and Son (ibid.), pp. 81-3.

8 Praise of My Lady (Defence of Guenevere), pp. 241-5.

- The Haystack in the Floods (ibid.), pp. 215-22.

in The King of Denmark's Sons (Poems by the Way), pp. 66-7. 


\section{AR'THUR HUGH CLOUGH}

\section{$1819-1861$}

Poets in general love to preach, and to a congregation. When they soliloquize they choose a market place. For a very few the primary, if not the final, forum is themselves. Afterwards they may be persuaded to admit the public to their confidence. At the moment of singing they had been honestly unaware of its existence. They resorted to poetry simply because they knew of no better instrument with which to hammer out thoughts vital to their own souls. If the resulting ideas fail to touch other hearts or ears they do not mind. Their disregard of sympathy, the occasional crudity of form, have no common origin with the roughness of a writer who, having studied his art as a violinist studies his, challenges criticism to disentangle the beauty from the excrescences concealing it. These solitaries do not concern themselves with the artistic requirements of the medium of expression they have adopted. They harbour no intention, unless to mould and develop a conception or an aspiration.

To that limited class of poets who are thinkers first, Arthur Hugh Clough belongs. Nature, however, endowed him with poetical gifts more or less independent of his other specific characteristics. Thus, a peculiarly delicate sense of tone is apparent, intermittently, at various periods of his career. A River Pool, written when he was twentyone, has

a dreamy sound

Of ripples lightly flung. ${ }^{1}$ 
A religious poet of the early seventeenth century would not have disdained the harmony of The Music of the World and of the Soul, which dates from the same stage of his life. All in the first of the Songs in Absence, twelve years later, seems ordinary; and yet there is charm :

The billows whiten and the deep seas heave;

Fly once again, sweet words, to her I leave,

With winds that blow return, and seas that swell,

Farewell, farewell, say once again, farewell. ${ }^{2}$

Besides charm, there is-a rare quality with him-warmth, too, as of a lover, in his song of Endymion on Latmos :

Can it be, and can it be ?

Upon Earth, and here below,

In the woodland at my side

Thou art with me, thou art here.

'Twas the vapour of the perfume

Of the presence that should be,

That enwrapt me !

That enwraps us,

O my Goddess, O my Queen !

And I turn

At thy feet to fall before thee ;

And thou wilt not:

At thy feet to kneel and reach and kiss thy finger-tips;

And thou wilt not:

And I feel thine arms that stay me,

And I feel-

O mine own, mine own, mine own,

I am thine, and thou art mine ! ${ }^{3}$

Dipsychus's accompaniment to the gliding of the gondola is the poetry of motion-very Venice :

How light we go, how soft we skim !

And all in moonlight seem to swim.

In moonlight is it now, or shade ?

In planes of sure division made, 
By angles sharp of palace walls The clear light and the shadow falls; $\mathrm{O}$ sight of glory, sight of wonder ! Seen, a pictorial portent, under, $O$ great Rialto, the vast round Of thy thrice-solid arch profound !How light we go, how softly! Ah, Life should be as the gondola !*

Equally delightful for the mere rhythmic flow is the herdgirl's hastening cry to her cows :

The skies have sunk, and hid the upper snowHome, Rose, and home, Provence and La PalieThe rainy clouds are falling fast below, And wet will be the path, and wet shall weHome, Rose, and home, Provence and La Palie !

Ah dear, and where is he, a year agone,

Who stepped beside and cheered us on and on ?

My sweetheart wanders far a way from me,

In foreign land, or on a foreign sea-

Home, Rose, and home, Provence and La Palie ! 5

So captivating indeed to the ear is Clough's verse that I am afraid of being accused of leading by false pretences to the study of a volume which, as a whole, will have for many no corresponding attractiveness in other ways.

Yet none seemed better fitted than he at the outset of his poetical career to win the sympathy of the public. In his first known poem, The Bothie of Tober-na-Vuolich, he manifested powers as popular as they are high. There could be no more vivid description of a typical Highland scene than that of the reading party's bathing place :

There is a stream

Springing far off from a loch unexplored in the folds of great moun. tains,

Falling two miles through rowan and stunted alder, enveloped Then for four more in a forest of pine, where broad and ample 
Spreads to convey it the glen with heathery slopes on both sides; Broad and fair the stream, with occasional falls and narrows ; But where the glen of its course approaches the vale of the river, Met and blocked by a huge interposing mass of granite Scarce by a channel deep-cut, raging up, and raging onward, Forces its flood through a passage so narrow a lady could step it. There, across the great rocky wharves, a wooden bridge goes, Carrying a path to the forest ; below, three hundred yards, say, Lower in level some twenty-five feet, through flats of shingle, Stepping-stones and a cart-track cross in the open valley.

But in the interval here the boiling pent-up water Frees itself by a final descent, attaining a basin, Ten feet wide and eighteen long, with whiteness and fury Occupied partly, but mostly pellucid, pure, a mirror ; Beautiful there for the colour derived from green rocks under; Beautiful, most of all, where beads of foam uprising Mingle their clouds of white with the delicate hues of the stillness, Cliff over cliff for its sides, with rowan and pendant birch boughs. Here it lics, unthought of above at the bridge and pathway, Still more enclosed from below by wood and rocky projection. You are shut in left alone with yourself and perfection of water, Hid on all sides, left alone with yourself and the goddess of bathing. ${ }^{6}$

\section{A Long Vacation party's humours were never better} reported. We hear the learned Tutor's grave dissertations, as on nature's objections to equality :

Star is not equal to star, nor blossom the same as blossom; There is a glory of daisies, a glory again of carnations ; Were the carnations wise, in gay parterre by green-house, Should it decline to accept the nurture the gardener gives it, Should it refuse to expand to sun and genial summer, Simply because the field-daisy that grows in the grass-plat beside it, Cannot, for some cause or other, develop and be a carnation ? Would not the daisy itself petition its scrupulous neighbour ? ' Up, grow, bloom, and forget me ; be beautiful even to proudness, E'en for the sake of myself, and other poor daisies like me '?

Contemporaries were able, and amused, to follow the gay banter of his pupils among themselves, not extraordinarily 
witty, any more than their sage instructor's philosophy was particularly convincing, but bright and diverting; the playing at study and at love making; the hospitalities of chieftains and local noblemen, when Oxford undergraduates were still novelties in the North. The whole took fast hold at once of the public taste. Hope of Ilay, Lindsay the Piper, Poet and Chartist Hewson, 'Arthur' Audley, and the great Hobbes,

Contemplative, corpulent, witty,

became household words. Even the metre, odious from other pens, was accepted smilingly from Clough-hexameters in deshabille.

There he and his world were in entire unison. That he possessed the gifts, had he chosen to use them, for continuing to keep it in good temper, is evident from the splendour, the fire, of Peschiera :

You say, 'Since so it is,-good-bye

Sweet life, high hope ; but whatsoe'cr

May be, or must, no tongue shall dare

To tell, "The Lombard feared to die !",

Ah ! not for idle hatred, not

For honour, fame, nor self-applause,

But for the glory of the cause,

You did, what will not be forgot.

And though the stranger stand, 'tis true,

By force and fortune's right he stands ;

By fortune which is in God's hands,

And strength, which yet shall spring in you.

This voice did on my spirit fall,

Peschiera, when thy bridge I crost,

' 'Tis better to have fought and lost,

Than never to have fought at all !'s

The like irresistible ardour illuminates a second thanksgiving for the same or a sister scene of patriot disappointment : 
Say not, the struggle nought availeth,

The labour and the wounds are vain,

The enemy faints not, nor faileth,

And as things have been they remain.

If hopes were dupes, fears may be liars ;

It may be, in yon smoke concealed,

Your comrades chase e'en now the fliers,

And, but for you, possess the field.

For while the tired waves, vainly breaking,

Seem here no painful inch to gain,

Far back, through creeks and inlets making,

Comes silent, flooding in, the main.

And not by eastern windows only,

When daylight comes, comes in the light,

In front, the sun climbs slow, how slowly,

But westward, look, the land is bright. ${ }^{9}$

The obligation of such a faculty is acknowledged in one of his latest poems. But from the first the poet's instinct in him had to fight an uphill, a losing, battle against the claim of moral, religious, and intellectual doubt to his soul's absolute service. The time was one of mental and spiritual questionings, active especially among pupils of Arnold. Though they were perilously disturbing in the great teacher's own son, poetry with him held on the whole its own. Matthew Arnold's admired friend, his Thyrsis, had a less imperious imagination, or a more restlessly logical conscience. Poetry, if it flamed up spontaneously in Clough at intervals, contracted a habit of embodying abstractions. For myself I confess to not being superior to commonplace regrets for the Peschieras we may have consequently forfeited.

At the same time I could not, from a literary point of view itself, wish it otherwise. Whatever else we might have gained we must have forfeited divers lofty meditations 
in various music on one same text. It would have been hard to resign the moving, if unhopeful, cry of Parting :

$\mathrm{O}$ tell me, friends, while yet ye hear,May it not be, some coming year,

These ancient paths that here divide Shall yet again run side by side, And you from there, and I from here, All on a sudden reappear?

$\mathrm{O}$ tell me, friends, while yet ye hear !

0 tell me, friends, ye hardly hear,And if indeed ye did, I fear

Ye would not say, ye would not speak,Are you so strong, am I so weak, And yet, how much so e'er I yearn, Can I not follow, nor you turn ?

0 tell me, friends, ye hardly hear ! ${ }^{10}$

Whence could we have replaced the solemn music of the appeal against dogmatizing on the Unknowable ?

O Thou, in that mysterious shrine Enthroned, as I must say divine !

I will not frame one thought of what

Thou mayest either be or not.

I will not prate of 'thus' and 'so', And be profane with ' yes' and ' no', Enough that in our soul and heart Thou, whatsoe'er Thou mays't be, art.

Unseen, secure in that high shrine Acknowledged present and divine, I will not ask some upper air,

Some future day to place Thee there ;

Nor say, nor yet deny, such men

And women saw Thee thus and then:

Thy name was such, and there or here

To him or her Thou didst appear.

Do only Thou in that dim shrine,

Unknown or known, remain, divine ; 
There, or if not, at least in eyes

That scan the fact that round them lies, The hand to sway, the judgment guide, In sight and sense, Thyself divide :

Be Thou but there,-in soul and heart, I will not ask to feel Thou art.11

For myself I should be loath to have lost even the unsatisfying Easter Day Odes-Christ not risen, yet risen-the Questioning Spirit; and Bethesda.12 Together with these and other work of mark, we should, worst of all, have missed from literature a genuine amalgam of verse and meditation, the soul that nature designed Arthur Clough's to be, the real man. Whether at all, or how far, he succeeded in discovering a clue to the probdems he handles, whether he might not, by passing them by, have had a brighter career, and been happier personally, is a different matter. To me he never appears to have felt that, with all his self-questionings, he had pioneered a via media. But my concern here is with him as poet-thinker ; and in that double capacity he has won, without asserting a right, a distinct and honoured place. I do not assert that he proclaims his views either jubilantly or convincingly. I am sure that the strain is honest, is reverent, tends to lift on high, and is the singer's own.

It is all this ; yet his poems, with the brilliant exception of The Bothie of Tober-Na-Vuolich, were little read in his lifetime. With the same exception, they are less read now. How few have ever heard of Dipsychus, the wayward, vexing, fascinating maze of casuistry, into which he poured his whole soul! The English public takes small delight in philosophical poetry ; and such, it pronounces, is Clough's. He wanders about Victorian literature like a phantom. Sometimes, however, phantoms are more of 
forces than are substances; and it may happen to be so with this. It is in truth difficult to believe that a spirit so gracious, so eager to learn and teach, so open-minded, so penetrating in its insight, so star-like, so generously fiery against injustice and tyranny, and against them alone, can actually be as evanescent in its influence as the deadness of popular interest in the works it permeates would seem to prove.

Poems by Arthur Hugh Clough. With a Memoir. Sixth Edition. Macmillan \& Co., 1878.

1 A River Pool (Early Poems), p. 7.

${ }^{2}$ Songs in Absence, st. 4, p. 277.

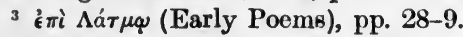

- Dipsychus (published after Clough's death), Part II, Sc. 2, pp. 101-2.

${ }^{5}$ Ite Domum saturae (Miscellaneous Poems), p. 334.

- The Bothie of Tober-na-Vuolich, 3, pp. 171-2.

' Ibid., 2, p. 167. ${ }^{8}$ Peschiera (Miscellaneous Poems), p. 343.

$\checkmark$ Say Not (ibid.), p. 345.

${ }^{10}$ Parting (Early Poems), stanzas 3-4, p. 32.

${ }^{11} \tilde{v}_{\mu \nu \nu o s} a ̂ v \mu \nu o s$ (Religious Poems), stanzas 3-5, pp. 52-3.

${ }_{12}$ Easter Day (Naples, 1849) (Religious Poems), pp. 61-6. Easter Day, II, pp. 67-8. The Questioning Spirit (Poems on Life and Duty), pp. 143-4. Bethesda, a Sequel (ibid.), pp. 145-6. 


\section{MATTHEW ARNOLD}

\section{$1822-1888$}

I HAVE no ghoulish taste for visiting charnel-houses; but the Escurial is more of a tomb than a palace. There it seemed natural to descend into the royal vaults. Not among the Monarchs, where her Consort was to lie, but in an ante-chamber was the coffin of his loved and lost young Montpensier Queen and Bride. Not for her to rest with Sovereigns ; for she had left no child to reign. Matthew Arnold established no dynasty, annexed no province of poetry ; so, I suppose, he must repose for the present not with, though beside, the Kings of Song.

Gladly I believe that he will be crowned in his grave by posterity ; for I myself account him worthy. As it is, he is a king de jure rather than de facto. I cannot deny that the reading public has not yet pronounced for his enthronement. If I may modify the metaphor as to dignities, I would say that he has been Beatified, not for the present Sanctified. His poetry is not of a kind to be spontaneously popular. It is a scholar's poetry, with the drawback of being, not so much over-learned, as over-educational. It is free from eccentricity, grctesqueness, rhetoric ; and its freedom has operated in its disfavour. It makes no effort to amuse with story-telling, history, or burlesque. The singer kept an abundant store of humour, if full of gall, for his brilliant prose. None diversifies his poetry, unless it be discoverable in his ten-years' ineffectual wooing of blueeyed, pale, and angelically grave Marguerite by the 'gleam- 
lighted lake', and on the Terrace at Berne. Though the sin of monotony cannot be charged against his verse, not many keys are touched. Such as sound are all solemn and austere. Then, no Matthew-Arnold-Cult has arisen. No congregation, however minute, of reverent disciples gathers together in his name. Persons of refinement admire. They nurse the emotion in their own breasts. They fear to vulgarize it by publishing it abroad. The controversial fame which he acquired in the concluding stages of his career has itself in a way acted adversely. The sentiment of his essays was, though in the bitter without the sweet, akin to that of his verse. In latter days his poetry often appeared to be regarded as an appendage to his essays rather than they to it.

Of the limitations, in fact, to his popularity there can be no question. They were necessary results of his whole habit of mind. He had an excessive tendency towards considering the poet a preacher, towards chanting homilies on the low aims and pursuits of modern society, its tinsel, its earthiness. He laid himself open to the reproach of parading as a discoverer of the hollowness of life. He was proud of being, through his honesty, a homeless wanderer forlorn from the hearth of orthodoxy. Sometimes he philosophized when he ought to have been singing. Often his thoughts pressed forward so eagerly as to threaten to stifle one another. Not merely are his poems unrelieved by a single flash of gaiety ; they are not lighted by a sparkle of joy. Lastly, and most detrimentally, he insisted upon, perhaps could not help, mixing the work of the critical with that of the creative faculty. He would sit in judgement upon the purity of his own inspiration; upon the quantity of candle-power of the tongues of fire as they alighted upon him. One and all are heavy fetters upon fancy; and as 
such the general, even the instructed, public has always felt them.

For an intimate circle they enhance respect for the powers which can burst through such obstacles. The drawbacks are for it the exalting defects of his Muse's qualities. Had he not deviated into preaching, we should, it will urge, have lost the heroic dirge of Rugby Chapel. No appeal, in Christ's name, would have been raised in Progress for sympathy with whatever Faith regenerates. Had he not been apt to confound philosophizing and singing, we might have been spared the cross-grained meditations of Empedocles, but should have missed the lovely interludes on the harp of Callicles. Three-fourths of The Buried Life are scarcely poetry; but without them we had lost the music of the close-the sudden pause in life's distracted turmoil :

A man becomes aware of his life's flow, And hears its winding murmur, and he sees The meadows where it glides, the sun, the breeze And there arrives a lull in the hot race Wherein he doth for ever chase That flying and elusive shadow, rest. An air of coolness plays upon his face, And an unwonted calm pervades his breast. And then he thinks he knows The hills where his life rose, And the sea where it goes. ${ }^{1}$

The Bacchanalia, without the rambling prelude, would not have danced from the silence of death into the silence of living light :

And o'er the plain, where the dead age

Did its now silent warfare wage-

O'er that wide plain, now wrapt in gloom,

Where many a splendour finds its tomb,

Many spent fames and fallen nights-

The one or two immortal lights 
Rise slowly up into the sky To shine there everlastingly, Like stars over the bounding hill. The epoch ends, the world is still. ${ }^{2}$

Without the vain effort in the Epilogue to Lessing's Laocoön to marshal the arts in their respective ranks, we should have lost the noble tribute to Music :

The words are utter'd, and they flee.

Deep is their penitential moan, Mighty their pathos, but 'tis gone.

Beethoven takes them then-those two

Poor bounded words!-and makes them new ;

Infinite makes them, makes them young;

Transplants them to another tongue,

Where they can now, without constraint,

Pour all the soul of their complaint,

And roll adown a channel large

The wealth divine they have in charge.

Page after page of music turn,

And still they live and still they burn,

Perennial, passion-fraught, and free-

'Miserere, Domine !' 3

Even when we feel him straining after an idea which evades his grasp, as in The Strayed Reveller, the tendrils of floating fancy cling to a hundred entrancing scenes. Egotistical is he? If any one is a licensed egotist, is not a poet? Weary, worn-out, blasé too, if he please, so long as the mood gives us melody delightfully acrid, like the final answer to the question, What is it to grow old?

It is-last stage of all-

When we are frozen up within, and quite

The phantom of ourselves,

To hear the world applaud the hollow ghost

Which blamed the living man; ${ }^{4}$ 
a hail-storm of sadness, like The Last Word :

Creep into thy narrow bed,

Creep, and let no more be said.

Vain thy onset! all stands fast !

Thou thyself must break at last.

Let the long contention cease !

Geese are swans, and swans are geese.

Let them have it how they will!

Thou art tired : best be still.

They out-talked thee, hiss'd thee, tore thee ?

Better men fared thus before thee !

Fired their ringing shot, and pass'd,

Hotly charged - and broke at last.

Charge once more, then, and be dumb !

Let the victors, when they come,

When the forts of folly fall,

Find thy body by the wall ! ${ }^{5}$

the exquisite glimpse of Kensington Gardens, caught through the afternoon sunshine of a serene despair :

Birds here make song, each bird has his,

Across the girdling city's hum.

How green under the boughs it is !

How thick the tremulous sheep-cries come ! ${ }^{6}$

or the contrast imaged in The Palladium-stately, cold marble, with a flush as from a deity within-between the calm of the soul and the discords of external existence :

It stood, and sun and moonshine rain'd their light

On the pure columns of its glen-built hall.

Backward and forward roll'd the waves of fight

Round Troy; but while this stood, Troy could not fall.

So, in its lovely moonlight lives the soul !

Mountains surround it, and sweet virgin air ;

Cold plashing, past it, crystal waters roll ;

We visit it by moments, ah, too rare ! 
Still doth the soul, from its lone fastness high, Upon our life a ruling effluence send; And, when it fails, fight as we will, we die, And while it lasts, we cannot wholly end. ${ }^{7}$

The drama of man's inner life, as seen by Arnold, is in many acts, with many parts, and many actors. It commences with a struggle; often the player cast for it never sees its end ; often it has no end ; and always it is grievous. The bitterness of it has pursued Heine to his grave in trim Montmartre :

Hark ! through the alley resounds

Mocking laughter ! A film

Creeps o'er the sunshine; a breeze

Ruffles the warm afternoon,

Saddens my soul with its chill !

Gibing of spirits in scorn

Mars the benignant repose

Of this amiable home of the dead. ${ }^{8}$

It had robbed him living of the one gift as a poet that he missed :

Charm, the glory which makes Song of the poet divine. ${ }^{9}$

It froze into eternal despair

that Lord Arundel,

Who struck, in heat, his child he loved so well And his child's reason flicker'd, and did die.

Painted-he will'd it_-in the gallery

They hang; the picture doth the story tell. ${ }^{10}$

It throbs unceasingly for some; like the old-world, never stilled, sorrowing of tawny-throated Philomela:

Eternal passion!

Eternal pain! ${ }^{11}$

Vainly it seeks to riot itself to forgetfulness, as in the dreary revelry of Mycerinus, whose 


\section{THE POETS}

sometimes wondering soul

From the loud joyful laughter of his lips

Might shrink half startled, like a guilty man

Who wrestles with his dream. ${ }^{12}$

It may bury itself in a living tomb, the Carthusians'

$$
\text { gloom profound, }
$$

Ye solemn seats of holy pain ! ${ }^{13}$

Always the contest is too unequal. At the close defeat is sure.

A time there was when humanity seemed at last to have grasped triumphantly a living Faith :

$\mathrm{Oh}$, had I lived in that great day,

How had its glory new

Fill'd earth and heaven and caught away

My ravish'd spirit too !

No thoughts that to the world belong

Had stood against the wave

Of love which set so deep and strong

From Christ's then open grave.

No lonely life had pass'd too slow

When I could hourly see

That wan, nail'd Form, with head droop'd low,

Upon the bitter tree.

Could see the Mother with the Child

Whose tender winning arts

Have to his little arms beguiled

So many wounded hearts!

While we believed, on earth he went,

And open stood his grave ;

Men call'd from chamber, church, and tent,

And Christ was by to save. ${ }^{14}$

That untenanted grave, and the vision of Him who had once lain therein, turned many a convulsion of despair, as in the adorable story of the Church of Brou, and its widowed Foundress, into angelic resignation-a resignation outlasting life : 
So sleep, for ever sleep. O marble pair ! Or, if ye wake, let it be then, when fair On the carved western front a flood of light Streams from the setting sun, and colours bright Prophets, transfigured Saints, and Martyrs brave In the vast western window of the nave ; And on the pavement round the tomb there glints A chequer-work of glowing sapphire tints, And amethyst, and ruby - then unclose Your eyelids on the stone where ye repose, And from your broider'd pillows lift your heads, And raise you on your cold white marble beds, And looking down on the warm rosy tints Which chequer, at your feet, the illumined flints, Say: 'What is this ? We are in bliss-forgivenBehold the pavement of the courts of Heaven!' Or let it be on autumn nights, when rain Doth rustlingly above your heads complain On the smooth leaden roof, and on the walls Shedding her pensive light at intervals The moon through the clere-story windows shines, And the wind washes 'mid the mountain pines; Then, gazing up through the dim pillars high, The foliaged marble forest where ye lie ; 'Hush '-ye will say-' it is eternity ! This is the glimmering verge of Heaven, and these The columns of the heavenly palaces!' And in the sweeping of the wind your ear The passage of the Angels' wings will hear, And on the lichen-crusted leads above The rustle of the eternal rain of love. ${ }^{15}$

And then-and then-alas for the world and the atoning blood of the Christ of Nazareth !

Now he is dead! Far hence he lies, In the lorn Syrian town, And on his grave, with shining eyes, The Syrian stars look down. ${ }^{16}$

The struggle is over, and a profound quiet succeeds; but 
scarcely even Balder's peace, ${ }^{17}$ where there was hope's glimmer, its pale ghost. Rather, the soul-suicide of the silent Alpine monastery, with its frost-bitten Belief, which is, for the world,

a dead time's exploded dream;

rather, the stillness of the tented field, with the opposed Persian and Tartar hosts in unconcerned animal repose, while, between them, in the hushed damp darkness, Sohrab, slain by his father's unknowing spear,

\section{lay dead,}

And the great Rustum drew his horseman's cloak Down o'er his face, and sate by his dead son. ${ }^{18}$

Matthew Arnold constantly dwells on one same note. For the close we always can imagine we hear a groan of decay and death in varying cadences of mournfulness. Sobs of protest, recognized by the mourner as unavailing, are raised audibly against the inevitable blankness, succeeded at best, by acquiescence in an ache beyond compare, which leaves no more to suffer. What though, throughout the whole, we are sensible of some affectation by the mourner of grief which does not grieve-some positive, preposterous pride in the remarkable elevation of soul which has elected him to be a remorseful sceptic instead of a common comfortable believer? At all events, artistic values in the picture are intuitively observed; and the painter moreover had actually passed through the spiritual experiences he portrays.

He had interrogated human nature; particularly, his own. He had ransacked libraries; always for his own mind's sake; to discipline, and enrich it ; to learn what manner of being he was. For him the one thing worth understanding was the complex organism of man's heart 
and intellect. To know it he used himself as subject, scalpel, and lecturer. His habit of identifying virtually the functions of writer and critic, was a necessity of the position he assumed. We can contemplate him dissecting his inner personality, noting how his soul, which originally had glowed with devotion, exulted in the discovery of its liberty-then-

Wandering between two worlds, one dead,

The other powerless to be born, ${ }^{19}$

chilled in the discord of contrary enthusiasms, harassed by rival claims to allegiance, scared, distracted, seared, benumbed-finally, when the company, lost in the storm,

at nightfall, at last

Comes to the end of its way,

To the lonely inn 'mid the rocks;

Where the gaunt and taciturn host

Stands on the threshold, the wind

Shaking his thin white hairs-

Holds his lantern to scan

The storm-beat figures, and asks :

'Whom in our party we bring?

Whom we have left in the snow ?' 20

was content to let the doubt remain unresolved even by himself, whether he will be of the remnant to whom the question is put. When now and again suspicion arises, as I have said, of a want of genuineness in the anguish, it can be admitted without too much offence to the honour of the sufferer. $\mathrm{He}$ is operator, though on himself, and his primary duty was to apply the knife. To find fault with his assumption of the double character is to strike at the basis of his intimate poetry; and with that we cannot afford to quarrel.

Take him as he is-body at once and surgeon, poet and 
critic-and study of his work will both inform and delight. Whether he vivisect his own soul, or another's, he himself remains the principal object of interest. The ScholarGipsy is a picturesque vision of the legendary being who had doffed the trammelling gown, yet could not tear himself out of hearing of Oxford's sweet jangling bells, among

the warm, green-muffled Cumner hills. ${ }^{21}$

So is departed Thyrsis, in the sister idyll redolent of the fragrant beauty alike of Lycidas, and the Ode to a Grecian Urn, yet distinct from both. But the final cause of each is to echo Matthew Arnold, and in each we search for and discover him. Byron himself does not loom more largely in every poem he wrote than Arnold in his. The more impressive the poet and his verse, the more we feel the critic, the psychologist, analysing, anatomizing every tissue, every nerve-centre; and we admire and sympathize with both the more.

He was born a poet; and he had trained himself to be a consummate artist in words. Milton in the choruses of Samson Agonistes has not equalled the flexible harmony of the blank verse of Rugby Chapel and Heine's Grave. Tennyson in the Swan's death-song scarcely surpasses Dover Beach in the music of the ebb, and

Its melancholy, long, withdrawing roar. ${ }^{22}$

I am afraid to praise, lest I be accused of exaggeration, the perfect accord of harmony and melancholy in the Forsaken Merman's cry of mild hopelessness :

Children, at midnight,

When soft the winds blow, When clear falls the moonlight, When spring-tides are low;

When sweet airs come seaward From heaths starr'd with broom, 
And high rocks throw mildly

On the blanch'd sands a gloom;

Up the still, glistening beaches,

Up the creeks we will hie,

Over banks of bright sea-weed

The ebb-tide leaves dry.

We will gaze, from the sand-hills,

At the white, sleeping town;

At the church on the hill-side-

And then come back down;

Singing: 'There dwells a loved one,

But cruel is she!

She left lonely for ever,

The kings of the sea.' ${ }^{23}$

As I read and re-read, I perpetually light upon passages which, like this, would do honour to any genius, however exalted. I can well understand how such a master might have expected to attain to something of the width of celebrity which fell to an illustrious contemporary. But, as constantly, I note personal characteristics which explain at once the disappointment of his hope of common popularity, and the peculiarity of the recognition he won. His was natural inspiration of the highest, which had happened to be exposed to the contradictory influences of Thomas Arnold's Rugby, with its 'cheerful, radiant vigour', and Newman's dissatisfied, self-troubled Oxford. None can tell whether without the blend, or strife, literature would have gained or lost. It might have counted better matured Sohrab and Rustums. It must have gone without the Grande Chartreuse, the Obermann, Heine, and the Chapel. As it is, the poet has failed of general favour, and has secured an audience all his own. Never has the educated, that is, the Academically educated, section of the community been enveloped in a cloud of incense like this ! A poet, an inspired poet, and all for it ! Nothing in him 
of the obscurity of Sordello, which a mere student from London, Manchester, anywhere, is free to penetrate. All clear as the day to glasses burnt on the banks of Isis or Cam. The elect of Oxford and Cambridge can never read a line of Matthew Arnold without a consciousness of his eyes upon them. No wonder that his followers, travelstained like himself, fellow-wanderers, fellow-exiles, from the Promised Land, are fit and select-but few.

Poems by Matthew Arnold. Two vols. Macmillans, 1869.

1 The Buried Life, vol. ii, p. 114.

2 Bacchanalia ; or, The New Age, vol. ii, p. 75.

3 Epilogue to Lessing's Laocoön, vol. ii, p. 149.

4 Growing Old, vol. ii, p. $173 . \quad 5$ The Last Word, vol. ii, p. 178.

- Lines Written in Kensington Gardens, vol. ii, p. 186.

? Palladium, vol. ii, pp. 189-90.

- Heine's Grave, vol. ii, pp. 203-4.

${ }^{9}$ Ibid., p. 206.

10 A Picture at Newstead, vol. i, p. 198.

11 Philomela, vol. ii, p. 70.

12 Mycerinus, vol. i, p. 58.

13 Stanzas from the Grande Chartreuse, vol. ii, p. 219.

16 Obermann Once More, vol. ii, pp. 246-7.

${ }_{15}$ The Church of Brou, 3, The Tomb, vol. i, pp. 178-9.

${ }^{16}$ Obermann Once More, vol. ii, p. 248.

${ }^{17}$ Balder Dead, vol. i, pp. 110-12.

${ }^{18}$ Sohrab «nd Rustum, vol. i, p. 38.

19 Stanzas from the Grande Chartreuse, st. 15, vol. ii, p. 219.

20 Rugby Chapel, vol. i, pp. 229-30.

${ }^{21}$ The Scholar-Gipsy, vol. i, p. 249.

22 Dover Beach, vol. ii, p. 109.

${ }^{23}$ The Forsaken Merman, vol. i, pp. 189-90. 


\section{ROBERT BROWNING}

\section{$1812-1889$}

LITERARY history furnishes many examples of prose writers who have employed their wits and pens in deciphering their own thoughts and emotions. Some among many are Cicero, Marcus Aurelius, St. Augustine, Montaigne, Pascal, Rousseau, Sterne, perhaps Cervantes. We have to search before finding clear parallels in poetry. I do not mean that poets do not habitually light up their own minds for the delight and instruction of the public. That is of the essence of poetry. But they start by looking ahead, by trying to penetrate into other minds, and telling them what they, without knowing it, think. Their discoveries outside they carry within. At their leisure they take their spoil to pieces, repair, add, embellish, reconstruct, and give forth transformed.

Matthew Arnold and Robert Browning are prominent among the Great in English verse for beginning and ending on their own ground. Like all they were ready to gather suggestions from elsewhere. They valued them as mere material for their personal use and enlightenment. So far the two are alike; and yet none could differ more in the manner of their self-revealing. The one is something between historian and advocate, the other an inspired diarist. The one passionately narrates and comments, passionately apologizes, pleads, and defends. The other remembers, compares, foresees, soliloquizes, and is at once wholly personal, and as absolutely impersonal. A complete 
diagram of the working of Browning's mind might be drawn from his many successive volumes. Poets in general regard themselves as apostles commissioned to go out and teach. Being distinctively a poet, with a poet's idiosyncrasies, he did not refuse to let his voice be heard. He would not have denied that he rather preferred it as it sounded to an audience. But for the purpose disciples had to be at home with him. They had to listen, as, with entire dispassionateness, he conversed with himself aloud. His primary object was to tell himself what from day to day he thought. If readers in general did not follow, he might regret it or not. The accident did not lead him to change the form of his memoranda.

With this conception anybody who is sincerely anxious to profit by him has to begin. His way was to be for ever chasing, overtaking, catching at, the shadow of an idea flitting around; outside, it might be : by choice, within. Having grasped it, he would order, frequently torture, it to declare its substance. When the thing, unaccustomed to be thus rudely catechized, stood mute, he set to work imagining all possible beings it might be. One by one he held them up before it, to see whether they recognized kinsmanship. Often he was left clasping still an inveterately unsubstantial shadow. He had to clothe it with flesh and blood from his own large, warm, breathing, very human soul.

For the public, when at a long last it came to be inquisitive about him, for students and disciples from the first and always, that was the sum of the whole. The very diverse classes of his ultimate readers were content, if at times bewildered, that it should be so. They wandered in the gardens of his spacious nature, surveying it through what were bars for most of them, after the manner of 
visitors to the flowers and beasts in Regent's Park. They were interested to watch him whether at play or in earnest. I do not suppose that it was in the least his own point of view. The shadows were all palpable realities to him. If I may change the metaphor, he would not be aware that he had never removed the scaffolding from the buildings he had erected. It might be a complicated human fabric he had constructed out of casuistry, sensuality, love of imposture for its own sake as an art, the bases of the career of a charlatan like Paracelsus. Not a single prop or strut could be removed with safety. In tracking the strange fortunes of an Italian troubadour, warrior, master and victim of statecraft and lovecraft, such as the mysterious half mythological Sordello, of the Purgatorio, he had to retain as tight hold of every clue to the labyrinth as a mediaeval schoolman. The problems that he kept setting himself, at brief intervals, for upwards of half a century ! How deviously he wandered to find fresh enigmas; as, for instance, which was the true Christopher Smart ? ${ }^{1}$ The solutions with which he attempted, sometimes successfully, sometimes not, to satisfy himself ! The knots deliberately tied to be triumphantly, and as deliberately, loosened !

Poetry in his eyes was the science of life; and life mainly the life of a mind. That was life's essence without the accidents. The one proper instrument for operating upon it was introspection of, and by, the operator; as Matthew Arnold also found, though from a dissimilar point of view, and with recourse to very dissimilar processes. Melody, orthodox melody, Browning allowed, might serve as an auxiliary; its help was not so important that it was worth purchasing by sacrifices. Above all, nothing in an idea, a thought, a feeling, must be resigned in its favour. Poets are alleged to have pared down a 
thought for the sake of a rhyme or rhythm. They have been said to be capable of letting a rhyme introduce a thought. Browning would have scorned to give up the least particle of an idea at the demand of diction. He never scrupled to manufacture terms and phrases as clothes for an idea. Rather than suffer rhyme to lead thought, he coined rhymes also. He may seem to be prolix. Again, it is thought which is to blame; some idea will have had to disentangle itself painfully from encumbering matter; or it is growing, and needs additional raiment in the shape of speech. Its parent never dreamt of refusing so natural, necessary, even laudable, a demand.

The Ring and the Book reports in four volumes a criminal trial. That is the poem's outward guise. The reality is a microscopic analysis of the life-beats of a group of hearts. Measure its right to the space not by the crime, not by the hearts, but by the pulsations of the reporter's brain; and there is not a page too many. Voluminous, if not diffuse, rugged and harsh, not careful to render the ideas he supremely prized intelligible-much less, palatable-to the ordinary Englishman, he stands, in the mass of his work, altogether apart both from his contemporaries and his predecessors. With all their variances and contrarieties, the several schools of poetry may be said at least to have agreed as a rule upon a measure of complimentary respect for the understanding of their public. Foremost among the few dissidents stands the author of Sordello, Caliban Upon Setebos, Prince Hohenstiel-Schwangau, Red Cotton Night-Cap Country, Fifine at the Fair, The Inn Album, Jocoseria, Parleyings with Certain People, La Saisiaz, the two Poets of Croisic, and Asolando. No charge can be lodged against him of having pandered to the popular taste, or ignorance. 
The complacency with which he launched upon literature this rapid succession of conundrums enraged the contemporaries of two-thirds of his career. He never appeared to be aware of the shocks he was administering. His general uncouthness seemed the more audacious in the face of a store of most tuneful occasional poems with which he interspersed his habitual experiments upon the endurance of readers. At will he showed that, when he chose, none could be more melodious than he. By turns he was gentle and fiery, able to unseal the fountain of laughter and the fountain of tears. $\mathrm{He}$ was majestic, terrible, simple, tender-even to imposture, if hungry-content, with a profound thought beneath, to be just graceful. With the sense upon us of the works by which apparently he meant his name to live, we ask, not so much why usually he clashes the harp strings, as why the psychologist, the metaphysician has suddenly strayed into absolute singing. Was he moved by compassion for the bewildered and dazed critic? Was he himself weary of untunefulness? May it not have been that the music always underlay the philosophy, that the philosophy was always ready, in favouring circumstances, to break into song-that life's 'scowl of cloud' hides behind it

\section{splendid a star ? ${ }^{2}$}

I have been glancing through the lyrics scattered over many volumes. It would be hard to say where else can be found a more absolute combination of thought, sentiment, rhythm-or where more variety.

In the Lost Leader I read reproach, amazement, revolt, admiration, hope that he, the renegade, will keep his prowess in fighting the followers he has deserted-that he will repent in death-be theirs once more in Heaven-for they love him : 
Let him never come back to us ! 'There would be doubt, hesitation, and pain, Forced praise on our part-the glimmer of twilight, Never glad confident morning again !

Best fight on well, for we taught him-strike gallantly Menace our heart ere we master his own; Then let him receive the new knowledge and wait us,

Pardoned in heaven, the first by the throne $!^{3}$

Bitter humour in The Soliloquy of a Spanish Cloister blasts hypocrisy hiding under a cowl. The soliloquy is a microcosm. It is an entire play, which sums up the passions of universal humanity, raving in a petty monastery, inside a pettier breast. The joy of setting a trap to catch saintly Brother Lawrence!

There 's a great text in Galatians

Once you trip on it, entails

Twenty-nine distinct damnations,

One sure if another fails ;

If I trip him just a-dying,

Sure of heaven as sure can be

Spin him round, and send him flying

Off to hell, a Manichee ! ${ }^{4}$

In another spirit, weariness of the yoke of liberty becomes a hymn to a Guardian Angel to 'bend me low', like Guercino's pictured child at Fano :

And lay, like his, my hands together,

And lift them up to pray, and gently tether

Me, as Thy lamb there, with thy garments spread. ${ }^{5}$

Or defiance is hurled at Death :

Fear death ?-to feel the fog in my throat,

The mist in my face,

When the snows begin, and the blasts denote

I am nearing the place,

The power of the night, the press of the storm,

The post of the foe;

Where he stands, the Arch Fear in a visible form,

Yet the strong man must go ; 
For the journey is done and the summit attained, And the barriers fall,

Though a battle's to fight ere the guerdon be gained,

The reward of it all.

I was ever a fighter, so-one fight more,

The best and the last !

I would hate that death bandaged my eyes, and forbore,

And bade me creep past.

No! let me taste the whole of it, fare like my peers

The heroes of old,

Bear the brunt, in a minute pay glad life's arrears

Of pain, darkness, and cold.

For sudden the worst turns the best to the brave,

The black minute 's at end,

And the elements' rage, the fiend-voices that rave,

Shall dwindle, shall blend,

Shall change, shall become first a peace out of pain,

Then a light, then thy breast,

$\mathrm{O}$ thou soul of my soul ! I shall clasp thee again, And with God be the rest ! ${ }^{6}$

And the love-songs ! To fit every phase-

Passion, hidden, the lover may believe, from all but the bud the loved one has named :

This flower she stopped at, finger on lip,

Stooped over, in doubt, as if settling its claim ;

Till she gave me with pride, to make no slip,

Its soft meandering Spanish name:

What a name! Was it love or praise ?

Speech half-asleep, or song half-awake?

I must learn Spanish one of these days,

Only for that slow sweet name's sake.

Flower, you Spaniard, look that you grow not,

Stay as you are and be loved for ever !

Bud, if I kiss you, 'tis that you blow not,

Mind, the shut pink mouth opens never !

For while it pouts, her fingers wrestle,

Twinkling the audacious leaves between,

Till round they turn and down they nestle-

Is not the dear mark still to be seen ?? 
A husband's glad choice-when bid fix his own reward for the rescue of France's sole surviving fleet-of one day's company of his wife as sufficient guerdon:

A beam of fun outbroke

On the bearded mouth that spoke,

As the honest heart laughed through

Those frank eyes of Breton blue;

'Since I needs must say my say,

Since on board the duty's done,

Since from Malo Roads to Croisic Point, what is it but

a run ?-

Since 'tis ask and have, I may-

Since the others go ashore-

Come ! a good whole holiday!

Leave to go, and see my wife, whom I call the Belle Aurore!'

That he asked, and that he got,-nothing more. ${ }^{8}$

A Parting, with seas to divide--and, perhaps, for ever !

Round the Cape of a sudden came the sea,

And the sun looked over the mountain's rim ;

And straight was a path of gold for him,

And the need of a world of men for me. ${ }^{9}$

A protest, in the presence of death, against a measurement of the right to love by Time's jealous milestones !-

I loved you, Evelyn, all the while!

My heart seemed full as it could hold-

There was place and to spare for the frank young smile,

And the red young mouth, and the hair's young gold.

So, hush,-I will give you this leaf to keep :

See, I shut it inside the sweet cold hand !

There, that is our secret : go to sleep !

You will wake, and remember, and understand. ${ }^{10}$

And, lastly, a lovely psalm of marriage-By the Firesidewhere passion and tenderness blend into one, and transmute the still aching agony of uncertainty in the wooing : 
$\mathrm{Oh}$, the little more, and how much it is !

And the little less, and what worlds away!

How a sound shall quicken content to bliss,

Or a breath suspend the blood's best play,

And life be a proof of this !- 11

into happy

pride

To think how little I dreamed it led

To image so blest that, by its side,

Youth seems the waste instead. ${ }^{12}$

Every lyric, every idyll, has its problem, though merged in an undercurrent of melody so bewitching that none are obliged to explore below. Abt Vogler, of musical renown, defies poet and painter, only human workers, noble as are their arts, to rival his, where

is the finger of God, a flash of the will that can,

Existent behind all laws, that made them and, lo, they are! And I know not if, save in this, such gift be allowed to man,

That out of three sounds he frame, not a fourth sound, but a star.

Consider it well : each tone of our scale in itself is nought ;

It is everywhere in the world-loud, soft, and all is said : Give it to me to use! I mix it with two in my thought

And, there! Ye have heard and seen : consider and bow the head! And at the height of his exultation :

It is gone, the palace of music I reared!

Well, it is earth with me ; silence resumes her reign :

I will be patient and proud, and soberly acquiesce.

Give me the keys. I feel for the commion chord again,

Sliding by semitones, till I sink to the minor,-yes, And I blunt it into a ninth, and I stand on alien ground,

Surveying awhile the heights I rolled from into the deep ;

Which, hark, I have dared and done, for my resting place is found,

The C Major of this life : so, now I will try to sleep..$^{13}$

In the glory of his life the Musician confesses failure; while death, three centuries earlier, leads the triumph of the Grammarian. I know few poems in which the reader 
can be more present with the poet in the access of inspiration. We feel his successive thrills of joy, as he climbs step by step with the adoring scholars up through the dust of buried learning into the pure ether of reborn Hellenism :

Let us begin and carry up this corpse,

Singing together.

Leave we the unlettered plain its herd and crop;

Seek we sepulture

On a tall mountain, citied to the top,

Crowded with culture !

All the peaks soar, but one the rest excels ;

Clouds overcome it ;

No, yonder sparkle is the citadel's

Circling its summit.

Thither our path lies; wind we up the heights;

Wait ye the warning?

Our low life was the level's and the night's ;

$\mathrm{He}$ 's for the morning.

Step to a tune, square chests, erect each head,

'Ware the beholders!

This is our master, famous calm and dead,

Borne on our shoulders.

He was a man born with thy face and throat,

Lyric Apollo!

Long he lived nameless : how should spring take note

Winter would follow ?

Till lo, the little touch, and youth was gone !-

Cramped and diminished,

Moaned he, 'New measures, other feet anon,

My dance is finished ?'

No, that 's the world's way (keep the mountain-side,

Make for the city !)

He knew the signal, and stepped on with pride

Over men's pity ;

Left play for work, and grappled with the world

Bent on escaping :

'What 's in the scroll,' quoth he, ' thou keepest furled ?

Show me their shaping, 
Theirs who most studied man, the bard and sage,-

Give !'-So, he gowned him,

Straight got by heart that book to its last page ;

Learned, we found him.

Yea, but we found him bald too, eyes like lead,

Accents uncertain ;

' 'Time to taste life,' another would have said,

' Up with the curtain!'

This man said rather, 'Actual life comes next ?

Patience a moment !

Grant I have mastered learning's crabbed text,

Still there 's the comment.'

$\mathrm{Oh}$, such a life as he resolved to live,

When he had learned it,

When he had gathered all books had to give !

Sooner, he spurned it.

Others mistrust and say, 'But time escapes ;

Live now or never !'

He said, 'What's time? Leave Now for dogs and apes!

Man has Forever!'

Back to his studies, fresher than at first,

Fierce as a dragon

He, soul-hydroptic with a sacred thirst,

Sucked at the flagon.

So, with the throttling hands of death at strife,

Ground he at grammar;

Still, thro' the rattle, parts of speech were rife ;

While he could stammer

He settled 'Hoti's' business-let it be :-

Properly based 'Oun'-

Gave us the doctrine of the enclitic 'de',

Dead from the waist down.-

Here's the top-peak; the multitude below

Live, for they can, there ;

This man decided not to Live but Know-

Bury this man there?

Here-here's his place, where meteors shoot, clouds form,

Lightnings are loosened,

Stars come and go ! Let joy break with the storm,

Peace let the dew send! 
Lofty designs must close in like effects : Loftily lying,

Leave him-still loftier than the world suspects, Living and dying. ${ }^{14}$

Whole libraries of the results of German research-patient as the Grammarian's own-could not reflect the ecstasy of the Renaissance, the magic of Golden Ages, Periclean, Augustan, come back to an amazed rough-hewn Gothic world-could not represent that world's debt to the early martyrs of learning, the Scaligers, Casaubons, who immolated lyric youth, gowned manhood, bald, hydroptic old age, dead from the waist down, battling with the expiring rattle over a due settlement of the enclitic 'de', a tenth part as intelligibly as the hundred and fifty trumpeting lines of this funeral chant !

An idea is always, somewhere, in everything Browning wrote. The variety of frankness, or the reverse, with which it reveals, or dissembles, itself is incalculable. Sometimes, as in a Lost Leader, Abt Vogler, a Grammarian's Funeral, he, more or less fully, unfolds it. Frequently the explanation is at hand, only a little below the surface, as in the accumulation to Martin Relph's remorse for his dastardly treachery, that the secret of his crime is safe, a torturing Hell in his own bosom :

'You were taken aback, poor boy,' they urge, 'no time to regain your wits :

Besides it had maybe cost you life.' Ay, there is the cap that fits. 15

Therein is the clear comfort to Hóseyn for the loss of his invincible mare, Muleykeh, that he alone holds the clue to her last victory; that none but himself understands how pride in her peerlessness could leave her with the robber rather than keep her shamed : 
And they jeered him one and all : 'Poor Hóseyn is crazed past hope ! How else had he wrought himself his ruin, in fortune's spite ? To have simply held the tongue were a task for a boy or girl, And here were Muléykeh again, the eyed like an antelope, The child of his heart by day, the wife of his breast by night !''And the beaten in speed!' wept Hóseyn: 'You never have loved my Pearl.' 16

Equally often we are left to grope about for an answer, as in Clive. ${ }^{17}$ We can but imagine possibilities with a selftormenting temperament, like his. Here he was, after thirty years of glory, brooding still with a shudder on disgrace which might have, but had not, befallen him in obscure boyhood. Such a nature would find the prospect of oblivion less intolerable than an old age of ease and a throng of other as rankling memories. I believe that the gallop from Ghent to Aix never had any specific historical foundation; that it is a parable of the essential grandeur of human effort, human sacrifice, without regard to the object; of the truth that unsparing endurance is never wasted, though there be no good news, no news at all to be good or bad.

Whether Browning indulged or baulked the curiosity of his admirers over a puzzle had nothing to do with their convenience. It depended wholly upon his own. A compensation is that he regarded them so little as to have no shyness in thinking in public. He would have minded as little if, taking the same liberty with his work, they presumed to complete an unfinished picture; to imagine, for example, the Pied Piper, kindly to the children as he had been vengeful to their sharp-dealing elders, playing eternal, wonderful music to the troop in gardens of Fairyland :

Where waters gushed and fruit-trees grew, And flowers put forth a fairer hue, And everything was strange and new. ${ }^{18}$ 
It is the same throughout. Browning, while he might be supposed to intend nothing but a song, was thinking, and often profoundly. In return, when meditating, he still sang. It would be idle for me to assert that in his work, outside his idylls and lyrics, melody is the primary attribute which a reader observes. Neither is it sentiment. The ear does not in Sordello, in Paracelsus, give, by drinking-in the music, the signal for the heart to glow. But whatever he wrote was poetry. None could ever mistake a dozen lines of his for prose. I would even go so far as to say, if a comparison had to be attempted, that, when he is not making experiments in rhythm, or on the forbearance of his admirers, his verse, for instance, in Christmas Eve and Easter Day, La Saisiaz, or Parleyings, could be shown to be more absolutely distinguishable rhythmically from prose than In a Year, or Home Thoughts from Abroad, and From the Sea. How various the blank verse is, and how strong! How it seems to have sprung, ripe and full, from the brain of power! The thought stands out from it as the muscles in a statue by Michel Angelo. Into a sentence it can condense more than could be expressed in a page of prose. It can take a sentence of prose, and draw from it a hundredfold the meaning.

Singular merits; and as singular defects; the defects of the writer's qualities; and with greatness in both. The self-communing, in particular, which lies at the basis of all his work, has its drawbacks. He would have rejoiced especially to shine as a dramatist. There the habit of dialogue unceasing might have been expected to be peculiarly valuable; and there, on the contrary, it mars the effect of his most promising enterprises. It renders them full of interest as poems; it pushes fatally into the background the action which is essential to a play's success. 
Action in drama ought constantly to be visible and various. In Strafford, and the rest, with the possible exception of noble Luria, the real performance is of thought, not deeds. The interchange of thoughts themselves proceeds, not between two or more persons, but between successive mental emotions or moods of one. Each of the pair affecting to converse might ordinarily to all effects and purposes be alone on the stage. The propensity to looking exclusively within is no less answerable for the kindred evil of carelessness, if not contempt, of public opinion. No English poet has ever equally affronted his readers with spasmodic diction, with a tangle, by no means always significant, of ragged rhythm and random rhymes.

There-I have discharged my critical conscience; and if there be any other shortcoming of Browning's, let it be massed with the rest. At all events we may be sure that the total indictment will not counterbalance the depth-not less in Caliban than in Christmas Eve and Easter Day-the thoroughness, the grandeur of purpose even when he seems to be revelling in horror-as in the Inn Album, Ivan Ivanovitch, Forgiveness-the precision, the eloquence, the scorn of meanness, the generosity, the something neither wit exactly, nor exactly wisdom, which is 'Mr. Sludge, the Medium'. How, from a crabbed, jagged stanza, the picture of

a castle, precipice-encurled,

In a gash of the wind-grieved Apennine, ${ }^{19}$

leaps forth, as if illuminated by a flash of lightning, to subside back the next moment into darkness! How he can suffuse a sombre reverie, like La Saisiaz, with a halo of pathos! How abruptly, yet naturally, in his narratives beauty and deformity, guilt and innocence, interlace, as a Pippa passes, with her happy lark-like songs, and as happy 
rags, by the villa which harbours squalid adultery and murder, with remorse as squalid!

Nowhere in the society of his verse is there room for tedium. We feel his meditations to be better company than talk. One whose friendship I have prized for more than forty years, as I hope and believe he has mine, once observed to me that ' reading Browning is like dram-drinking'. It enslaves ; and I am willing to believe that it might scarcely be for the good either of poets, or of their readers, that many sources of similar intoxicants should be set running. Whether fortunately or not, however, the danger of temptation at any rate is remote. Such a poet-soul as Browning's is reared not often or easily. We may well apply to himself his own account of a poet's birth :

Rock's the song-soil rather, surface hard and bare; Sun and dew their mildness, storm and frost their rage

Vainly both expend-few flowers awaken there;

Quiet in its cleft broods-what the after-age

Knows and names a pine, a nation's heritage. ${ }^{20}$

The Poetical Works of Robert Browning. Six vols. Smith, Elder \& Co., 1868 :-Balaustion's Adventure, 1871. Prince HohenstielSchwangau, 1871. Fifine at the Fair, 1872. Red Cotton Night-Cap Country, 1873. The Inn Album, 1875. Aristophanes' Apology, 1875. Pacchiarotto, \&c., 1876. The Agamemnon of Aeschylus, 1877. La Saisiaz, 1878. The Two Poets of Croisic, 1878. Dramatic Idyls, 1879. Dramatic Idyls, Second Series, 1880. Jocoseria, 1883. Ferishtah's Fancies, 1884. Parleyings with Certain People, 1887. Asolando, 1890.

1 Parleyings with Certain People, iii, With Christopher Smart, pp. 79-95.

2 The Two Poets of Croisic, Prelude, p. 85.

3 The Lost Leader (Dramatic Lyrics), Poet. Works, vol. iii, p. 79.

- Soliloquy of the Spanish Cloister, ibid., pp. 93-4.

5 The Guardian Angels; a Picture at Fano, ibid., p. 215.

- Prospice, Poet. Works, vol. vi, pp. 152-3.

2 The Flower's Name, stanzas 3 and 5 (Garden Fancies, Dramatic Lyrics), Poet. Works, vol. iii, pp. 87-8. 
${ }^{8}$ Hervé Riel (Pacchiarotto, \&c.), st. 10, p. 128.

- Parting at Morning (Dramatic Lyries), Poet. Works, vol. iii, p. 107.

${ }^{10}$ Evelyn Hope, st. 7 (Dramatic Lyrics), ibid., p. 112.

11 By the Fire-side, st. 39 (Dramatic Lyrics), ibid., p. 179.

12 Ibid., st. 25 (Dramatic Lyrics), ibid., p. 176.

${ }^{13}$ Abt Vogler (After he has been playing upon the Instrument of his Invention), stanzas 7 and 12 (Dramatis Personae), Poet. Works, vol. vi, pp. 95-6 and 98.

16 A Grammarian's Funeral, Shortly after the Revival of Learning in Europe (Dramatic Romances), Poet. Works, vol. iv, pp. 270-5.

${ }_{15}$ Martin Relph (Dramatic Idyls, 1879), pp. 4-5.

${ }^{16}$ Muléykeh (Dramatic Idyls, Second Series, 1880), p. 59.

${ }^{17}$ Clive (ibid.), pp. 9-42.

16 The Pied Piper of Hamelin, st. 13 (Dramatic Romances), Poet. Works, vol. iv, p. 234.

${ }^{10}$ De Gustibus, st. 2 (Dramatic Lyrics), Poet. Works, vol. iii, p. 143.

${ }^{20}$ Dramatic Idyls, Second Series, Epilogue, p. 149. 


\section{ALFRED TENNYSON}

$1809-1892$

The poets-not only the great, but all the true-how each stands alone! Search the whole Golden Book; no double will be found for him with whom the register for the present closes; no real fellow for Alfred Tennyson ! The character of his genius was so unexpected that the general public took long to appreciate it. The delay was a tribute to its originality. To a few elect it was obvious and heavenly. I envy their joyous surprise. Mighty Wordsworth, in the opinion of a younger generation, had declined to prosing, however wisely. Hellenic Landor raved. Rogers was antediluvian; and poor Leigh Hunt had never counted. The giants of the past were buried in their past, when a chant as exquisite as theirs, and at least as new and strange, rose into the dead air. To a brilliant, youthful brotherhood it must have been as when Christabel or Childe Harold soared above the stagnant mists half a century earlier.

The initiated were enraptured with all. The present generation discriminates. To a certain extent it has lost touch with much of the philosophy of The Two Voices, The Palace of Art, The Vision of Sin. It has outgrown the gladness, the sweet limpid sorrow, of the May Queen and its sequels, the Early Victorian elegance of the Miller's and Gardener's Daughters ; even Locksley Hall the First, with its play of panoramic heart-flutterings. Though scarcely one discarded favourite but has lines, words, to 
set the pulse beating faster, the Lilians, Isabels, Madelines, Adelines, Margarets, and Eleanors, Mermen and Mermaidens, Orianas, Lords of Burleigh, and Ladies Clare and Clara, elicit smiles now instead of emotion. A large part, however, is fully as fresh as when first it danced into daylight. Custom cannot stale the radiant humours of Recollections of the Arabian Nights :

When the breeze of a joyful dawn blew free

In the silken sail of infancy,

The tide of time flowed back with me,

The forward-flowing tide of time ;

And many a sheeny summer-morn,

Adown the Tigris I was borne,

By Bagdat's shrines of fretted gold,

High-walled gardens green and old;

True Mussulman was I and sworn,

For it was in the golden prime

Of good Haroun Alraschid. ${ }^{1}$

The wild swan's death-hymn may be music only ; but such music !

At first to the ear

The warble was low, and full, and clear ;

And floating about the under-sky,

Prevailing in weakness the coronach stole

Sometimes afar, and sometimes anear ;

But anon her awful jubilant voice,

With a music strange and manifold,

Flow'd forth on a carol free and bold ;

As when a mighty people rejoice

With shawms, and with cymbals, and harps of gold,

And the tumult of their acclaim is roll'd

Thro' the open gates of the city afar,

To the shepherd who watcheth the evening star,

And the creeping mosses and clambering weeds,

And the willow branches hoar and dank,

And the wavy swell of the soughing reeds, 
And the wave-worn horns of the echoing bank, And the silvery marish-flowers that throng The desolate creeks and pools among, Were flooded over with eddying song. ${ }^{2}$

The land of the Lotos-Eaters basks still in mellow afternoon sunshine :

How sweet it were, hearing the downward stream, With half-shut eyes ever to seem

Falling asleep in a half-dream !

To dream and dream, like yonder amber light, Which will not leave the myrrh-bush on the height;

To hear each other's whisper'd speech ;

Eating the Lotos day by day,

To watch the crisping ripples on the beach,

And tender curving lines of creamy spray;

To lend our hearts and spirits wholly

To the influence of mild-minded melancholy ;

To muse and brood and live again in memory,

With those old faces of our infancy

Heap'd over with a mound of grass,

Two handfuls of white dust, shut in an urn of brass ! 3

We have not ceased to wander around the spell-bound sleeping palace-spell-bound ourselves-and its gardens :

Where rests the sap within the leaf,

Where stays the blood along the veins;

Faint shadows, vapours lightly curl'd,

Faint murmurs from the meadows come,

Like hints and echoes of the world

To spirits folded in the womb ;

waiting till the fairy prince has kissed back to life his destined bride :

And o'er the hills, and far away

Beyond their utmost purple rim,

Beyond the night, across the day,

Thro' all the world she follow'd him. ${ }^{4}$ 
The ancient wood has not lost for us its company of storied women; the

Daughter of the gods, divinely tall, And most divinely fair-

for whose beauty many drew swords and died; the

Queen with swarthy cheeks and bold black eyes

Brow-bound with burning gold;

who by Mark Antony's side ' sat as god by god ' ; murdered Iphigenia, and Rosamond, 'whom men call fair'; the Maid of France; and her who, to a cry of indignant pity for the victim of the Gileadite's wild oath,

rendered answer high :

'Not so, nor once alone; a thousand times I would be born and die.

My God, my land, my father-these did move Me from my bliss of life, that Nature gave,

Lower'd softly with a threefold cord of love

Down to a silent grave.

It comforts me in this one thought to dwell, That I subdued me to my father's will ;

Because the kiss he gave me, ere I fell, Sweetens the spirit still.

Moreover it is written that my race

Hew'd Ammon, hip and thigh, from Aroer

On Arnon until Minneth.' Here her face

Glow'd, as I looked at her.

She lock'd her lips; she left me where I stood ;

'Glory to God,' she sang, and past afar,

Thridding the sombre boskage of the wood,

Towards the morning star.

Losing her carol I stood pensively, As one that from a casement leans his head, When midnight bells cease ringing suddenly, And the old year is dead. ${ }^{5}$ 
Tennyson's imagination dwelt sometimes upon periods of history, as in The Dream of Fair Women, sometimes upon legend and tradition. Scenes, incidents, men and women, touched by him, have become his, and real because his. We see them as he saw them, and almost forget that they have had other and earlier owners. Through him, and for him, the Lady of Shalott is an actual being, who, wistfully impatient, fearful of she knows not what,

still in her web delights

To weave the mirror's magic sights,

For often thro' the silent nights

A funeral, with plumes and lights,

And music, went to Camelot. ${ }^{6}$

It is in his voice that pure Sir Galahad tells how he

Sometimes on lonely mountain-meres

Will find a magic bark;

' I leap on board; no helmsman steers ;

I float till all is dark.

A gentle sound, an awful light !

Three angels bear the holy Grail ;

With folded feet, in stoles of white,

On sleeping wings they sail.

Ah, blessed vision! blood of God !

My spirit beats her mortal bars,

As down dark tides the glory slides,

And starlike mingles with the stars!'

In a kindred ecstasy, the cloistered maiden of his inspired creation, keeps her vigil, beside even Keats's, on St. Agnes's Eve. The Lamb

lifts me to the golden doors;

The flashes come and go;

All heaven bursts her starry floors,

And strows her lights below, And deepens on and up ! the gates

Roll back, and far within 
For me the Heavenly Bridegroom waits,

To make me pure of sin.

The sabbaths of Eternity,

One sabbath deep and wide-

A light upon the shining sea-

The Bridegroom with his bride $!^{8}$

Few of us can think of the rivalry of the Three Olympian goddesses without picturing to ourselves, in that

$$
\text { vale in Ida, lovelier }
$$

Than all the valleys of Ionian hills,

the forlorn figure of Tennyson's Oenone, and hearing her passionate appeal to her Mother, to Earth :

I will not die alone,

Lest their shrill happy laughter come to me

Walking the cold and starless road of Death

Uncomforted, leaving my ancient love

With the Greek woman! 9

Even the desolation of forsaken Mariana in her moated grange is no longer Shakespeare's alone, but is shared with Tennyson :

With one black shadow at its feet,

The house thro' all the level shines,

Close-latticed to the brooding heat,

And silent in its dusty vines ;

A faint-blue ridge upon the right,

An empty river-bed before,

And shallows on a distant shore,

In glaring sand and inlets bright.

But 'Ave Mary', made she moan, And 'Ave Mary', night and morn, And 'Ah', she sang, ' to be all alone,

To live forgotten, and love forlorn.' 10

The charm in all he wrote is that each piece seems to have floated impulsively forth in the shape it keeps for vol. II 
us, although we know that in fact every one has been laboriously filed and burnished. Poems in which a severe expenditure of thought is manifest on their face, are yet diversified by carollings of bird-like melody. Listen to his protest against the counsels of despair embodied in the scholasticism of The Two Voices :

Tho' I should die, I know

That all about the thorn will blow

In tufts of rosy-tinted snow ;

Not less the bee would range her cells,

The furzy prickle fire the dells,

The foxglove cluster dappled bells. ${ }^{11}$

His poetic instinct relieves the lurid pomp of The Palace of Art by many a delicate natural touch :

An English home-gray twilight pour'd

On dewy pastures, dewy trees,

Softer than sleep-all things in order stored,

A haunt of ancient Peace;

Or the maid-mother by a Crucifix,

In tracts of pasture sunny-warm,

Beneath branch-work of costly sardonyx,

Sat smiling, babe in arm. ${ }^{12}$

Beyond the sardonic harshness of The Vision of Sin a divine glory becomes visible :

Every morning, far withdrawn

Beyond the darkness and the cataract,

God made himself an awful rose of dawn. ${ }^{13}$

Often he appears to compose without a text, without a theme, from no motive, except an irrepressible impulse to discourse sweet music :

Break, break, break,

On thy cold gray stones, O Sea !

And I would that my tongue could utter

The thoughts that arise in me. 
$\mathrm{O}$ well for the fisherman's boy,

That he shouts with his sister at play!

$O$ well for the sailor lad,

That he sings in his boat on the bay!

And the stately ships go on

To their haven under the hill ;

But $\mathrm{O}$ for the touch of a vanish'd hand,

And the sound of a voice that is still!

Break, break, break,

At the foot of thy crags, $O$ Sea !

But the tender grace of a day that is dead

Will never come back to me. ${ }^{14}$

Tennyson had done a life's work by the time he was thirty. For another half century he went on writing. Scarcely did he cease singing before in extreme age he ceased to breathe. He even continued to exercise, as in the two Northern Farmers, the gift of humour, which he had early manifested in the gay Monologue of the Cock, and, more grimly, in St. Simeon's thirstily meek acceptance of blasphemous idolatry. It is dangerous to oppose a critic of the intuition of 'Old Fritz', who deprecated his collegefriend's persistent poetic diligence. I must, however, disagree. If the later serious poems miss the delicate fragrance, the real or apparent spontaneity, the audacity, of their youthful predecessors, the want is no sufficient ground for impatience at the continuance on the stage of the doer of great things in the past. Had the subsequent volumes by the creator of Oenone and The Dream been failures all, I should not myself have ventured to quarrel with him for pursuing his vocation any more than with a last season's blackbird for warbling as soon as he feels the Spring in his throat. But in truth literature would itself have suffered a grievous loss had Tennyson rested on his gathered laurels. For the Plays alone I say nothing. 
A diversion, I will hope, to the writer, they have no business to survive him. Let them be decently buried-not in his grave; though some late violet may bloom even from their unmonumental mound.

Elsewhere we should have lost wealth of music had he been frightened, living, into silence by the shadow of his own fame. He would never have sung in the Garden at Swainston :

Nightingales warbled without,

Within was weeping for thee:

Shadows of three dead men

Walk'd in the walks with me,

Shadows of three dead men and thou wast one of the three.

Nightingales sang in his woods :

The Master was far away :

Nightingales warbled and sang

Of a passion that lasts but a day;

Still in the house in his coffin the Prince of courtesy lay.

Two dead men have I known

In courtesy like to thee :

Two dead men have I loved

With a love that ever will be :

Three dead men have I loved and thou art last of the three..$^{15}$

He would not have wrought that incomparable conceit, The Princess, or been tempted to inlay it with undying songs. We should then have been orphaned of the music in

$O$ hark, $O$ hear! how thin and clear, And thinner, clearer, farther going !

$\mathrm{O}$ sweet and far from cliff and scar The horns of Elfland faintly blowing !

Blow, let us hear the purple glens replying :

Blow, bugle ; answer, echoes, dying, dying, dying ;

and

Home they brought her warrior dead; 
with its exquisite tenderness :

Sweet my child, I live for thee. ${ }^{16}$

We should not have learnt how blank verse can be more lyrical than a lyric from,

'Tears, idle tears', I know not what they mean;

Tears from the depth of some divine despair

Rise in the heart, and gather in the eyes,

In looking on the happy Autumn-fields,

And thinking of the days that are no more. ${ }^{17}$

Criticism naturally was apt to detect fallings-off in a career so prolonged. Such doubtless there were; but how vast the balance of net gain to English literature ! If Maud is freakish, and its politics, sometimes its ethics, all astray, well might a complaint that it had never received justice, be expressed by the creator of beauty, a profusion of beauty, like :

A voice by the cedar tree,

In the meadow under the Hall !

She is singing an air that is known to me,

A passionate ballad, gallant and gay,

A martial song like a trumpet's call !

Singing alone in the morning of life,

In the happy morning of life and of May,

Singing of men that in battle array,

Ready in heart and ready in hand,

March with banner and bugle and fife

To the death for their native land.

Silence, beautiful voice!

Be still, for you only trouble the mind

With a joy in which I cannot rejoice,

A glory I shall not find.

Still! I will hear you no more,

For your sweetness hardly leaves me a choice

But to move to the meadow and fall before

Her feet on the meadow grass, and adore,

Not her, who is neither courtly nor kind,

Not her, not her, but a voice. ${ }^{18}$ 
I have myself felt inclined to condemn the Idylls of the King for unreality and prolixity; as if one had a right to require tales of chivalry to be rational, terse, sententious, pithy. When in a juster mood, I admit that he must be a fortunate student of romance who is conversant with any more fascinating than Geraint and Enid, Launcelot and Elaine, the Last Tournament, for all their diffuseness ; with aught more divine than Guinevere-where Tennyson found at length a worthy match for the else peerless creature of his youth-kingly Morte d'Arthur.

What streamlet, again, in a dell of Parnassus ever laughed more gaily than the Brook, escaped from its encumbering frame? Where is there a more happily inspired Prothalamion than the Welcome to Alexandra,

Bride of the heir of the kings of the sea ? 19

Where a battle-song to beat the Charge of the Six Hundred

Into the valley of Death ? ${ }^{20}$

Where a more triumphant funeral hymn than that on the Great Duke, with the grand break-the cry of the mighty Seaman from his tomb :

Who is he that cometh, like an honour'd guest, With banner and with music, with soldier and with priest, With a nation weeping, and breaking on my rest ? ${ }^{21}$

If impatience be felt at the resuscitation, at the grave's brink, of Locksley Hall, let it be remembered that three years later the worn brain demonstrated its victory over age by singing Crossing the Bar.

Long indeed before that, yet many years after FitzGerald would have silenced him, he had tried triumphantly a new strain. I well recollect the depth of the impression produced by the appearance of In Memoriam. No grander 
tribute, it was acknowledged, had ever been offered to the dead, even by Milton, or by Shelley. High as already was Tennyson's rank among poets, there had been doubters still. In Memoriam silenced them. It has never relaxed its hold on popular sympathy. Like his great predecessor's Intimations of Immortality, it was felt-and with a more attaching melody-to combine Inquiry and Poetry, to bo of the rare class of verse where

All the breeze of Fancy blows,

And every thought breaks out a rose. ${ }^{22}$

Lines in it have become part of ourselves. For many it is a manual of Faith :

What am I ?

An infant crying in the night :

An infant crying for the light:

And with no language but a cry.

I falter where I firmly trod,

And falling with my weight of cares

Upon the great world's altar-stairs

That slope thro' darkness up to God,

I stretch lame hands of faith, and grope,

And gather dust and chaff, and call

To what I feel is Lord of all,

And faintly trust the larger hope. ${ }^{23}$

For as many it is evidence for the Communion of Souls :

When summer's hourly-mellowing change

May breathe, with many roses sweet,

Upon the thousand waves of wheat,

That ripple round the lonely grange;

Come: not in watches of the night,

But where the sunbeam broodeth warm,

Come, beauteous in thine after form,

And like a finer light in light. 
I shall not see thee. Dare I say

No spirit ever brake the band

That stays him from the native land,

Where first he walk'd when claspt in clay?

No visual shade of some one lost,

But he, the Spirit himself, may come

Where all the nerve of sense is numb :

Spirit to Spirit, Ghost to Ghost.

$\mathrm{O}$ therefore from thy sightless range

With gods in unconjectured bliss,

$O$, from the distance of the abyss

Of tenfold-complicated change,

Descend, and touch, and enter; hear

The wish too strong for words to name ;

That in this blindness of the frame

My ghost may feel that thine is near. ${ }^{24}$

Nature had endowed Tennyson with certain qualities which defied the tendency of years to paralyse, or dull; his ear preserved its almost inimitable refinement, and instinct of harmony. His heart kept its fire in The Revenge and The Victim. Brain and it maintained their alliance. In every line he still painted a picture. He never described without having made himself see the scene; and he makes the reader see it through his mind's eye. With these inestimable gifts was conjoined, in an increasing rather than a diminishing degree, by experience, a judgement which waited, before intervening, for inspiration to play its primary part. Finally, born of unfailing self-respect first, and due regard for his public next, there was genius's infinite capacity for taking trouble. What a stern, Draconian critic he was of his own work, is manifest from a glance in the Life at the pieces he laid aside. Think of the 
exuberance of fancy which could afford to reject the Mother's Ghost, on account, perhaps, of some want of finish, which in fact enhances the sweetness!-

Not a whisper stirs the gloom,

It will be the dawning soon.

We may glide from room to room,

In the glimmer of the moon;

Every heart is lain to rest,

All the house is fast in sleep,

Were I not a spirit blest,

Sisters, I could almost weep !

In that cradle sleeps my child,

She whose birth brought on my bliss;

On her forehead undefiled

I will print an airy kiss;

See, she dreameth happy dreams,

Her hands are folded quietly,

Like to one of us she seems,

One of us my child will be. ${ }^{25}$

Of all the capacities, bestowed and acquired, the crowning result was a poet, and nothing but a poet, with no ambition but that. The aspiration was lofty, as was Tennyson's whole conception of a poet's rank and duties. While unknown to the world, he had magnified his vocation. It was the poet's inheritance, he boasted, to see through life and death, through good and ill, nay, through his own soul ; to be Wisdom's chosen interpreter :

\section{No sword}

Of wrath her right arm whirl'd,

But one poor poet's scroll, and with His word

She shook the world. ${ }^{26}$

His practice, within the limits of human strength, was in accordance. He desired to embody modern society's network of doubts in a marshalled legion of living and 
lived riddles, with the solutions, or attempts at them, appended. He could not pass a contemporary problem by without adventuring an answer. More than one coeval at home, and across the Atlantic, had, as I have shown, the same craving. His special advantage was the possession, over and above gifts he shared with others, of the secret of irresistible melody. When once the strangeness of his method was surmounted, that acted like a spell upon Anglo-Saxon intelligence. Long before the end he had steeped the realm of English verse in an atmosphere all his own. Except from within one tent in the wilderness, no lyre sounded which had not been tuned or retuned in unison with his. Under the stress of the unchallenged absoluteness of his ultimate supremacy, an effort is needed to recall that he had to fight for his throne; that he himself had often despaired, complaining that

Once in a golden hour

I cast to earth a seed.

Up there came a flower,

The people said, a weed. ${ }^{27}$

Have I overpraised ? I do not mean, in view of the very possible hint that I ought first to have considered what my eulogies were worth. To that taunt I know I have been exposing myself throughout my seventy comments. But, without regard to my title to an opinion at all, is the panegyric here out of just proportion to the claims of other poets? At any rate I have never concealed from myself my theme's deficiencies. I perceive that the liquid sweetness is too invariable. The ear pines for a little harshness, a sense of open air ; for an occasional unintentionally broken-backed line. The mellifluous style tempts to verboseness, particularly in the Idylls; in the rest, as 
well as those of The King, where, indeed, it is more excusable. At times it laboriously embalms a fly in amber. Too many knotty questions are lightly propounded. There is a propensity to mistake sitting upon the puzzles of existence for their investigation, if not for their settlement. Not rarely the art by which Gray in the Elegy produced the effect of entire simplicity fails Tennyson. Though very seldom, even his taste is now and then at fault. In brief, his theology, moral philosophy, science, and skill in the construction of a plot, are those of a poet, not of a Bishop Butler, a Darwin, or a Wilkie Collins. He sings darkling, not soaring. There is the feminine note in his music. He is not quite the magician or prophet some of his disciples proclaimed him. Scrutinized closely his art betrays flaws which the delicate finish had covered-and his Muse is the more adorable for them all!

Within its proper boundaries his sovereignty is in no hostile rivalry with that of his reigning predecessors. On the contrary, loyal admirers may freely admit that the ancient enthronements were a condition of his. Without Chaucer, Spenser, Milton, Wordsworth and Coleridge, Shelley and Keats, without Dryden and Pope too, Cowper, and Byron, he would not have been that he was. From them all he learnt to choose the good, and, as profitably, to refuse the evil. His poetic soul, could its elements be analysed, would render glad account of the bountiful proportion of their essence it owes to its forerunners. Yet he remains himself a distinct and gracious being. The lyrics in The Princess and in Maud, with all their Elizabethan daintiness, are as self-evidently his in their fire and feeling as are the wit and wisdom of his Northern Farmers' proverbial philosophy. It was, as I have already intimated, 
a glory and a blessing for the nineteenth century that, just when the peal of inspiration which struck up at its opening, seemed to have rung all conceivable changes of poetic thought and feeling, he arose to demonstrate that, given the man, the possible variations had in nowise been exhausted.

So may it be-so will it be-in the future as in the past, though, had the sun of great British singers actually been extinguished with Alfred Tennyson, its setting would not have dishonoured its dawn! 
The Works of Alfred, Lord Tennyson, Poet Laureate. Collected Edition, Macmillan, 1884.

1 Recollections of the Arabian Nights, st. 1. Collected Edition.

2 The Dying Swan. Ibid.

3 The Lotos-Eaters, Choric Song, st. 5. Ibid.

- The Sleeping Palace. Ibid.

- A Dream of Fair Women. Ibid.

- The Lady of Shalott, Part II. Ibid.

- Sir Galahad. Ibid.

' St. Agnes' Eve. Ibid.

- Oenone. Ibid.

10 Mariana in the South. Ibid.

11 The Two Voices. Ibid.

12 The Palace of Art. Ibid.

13 The Vision of Sin. Ibid.

14 Break, break, break. Ibid.

${ }^{13}$ In the Garden at Swainston. Ibid.

${ }^{16}$ The Princess: A Medley, 6. Ibid.

17 Ibid., 4. Ibid.

${ }^{18}$ Maud: A Monodrama, 1 and 3. Ibid.

19 A Welcome to Alexandra. Ibid.

${ }^{20}$ The Charge of the Light Brigade. Ibid.

${ }^{21}$ Ode on the Death of the Duke of Wellington, st. 6. Ibid.

${ }_{22}$ In Memoriam, 122. Ibid.

${ }^{23}$ Ibid., 54 and 55. Ibid.

24 Ibid., 91 and 93 . Ibid.

${ }^{25}$ Life of Lord Tennyson by his Son, vol. i, pp. 124-5.

${ }^{26}$ The Poet. Collected Edition.

27 The Flowers (The Princess and Other Poems). Ibid. 


\section{UNCLASSED}

InSPIRATION always is unexpected; a surprise, I should suppose, to the poet, as it is to his readers. The unexpectedness, as he and they suddenly find themselves on wings borne aloft into the empyrean of fancy, is a chief virtue of great verse. At the same time, we have a positive right to look for it in accepted poets, in the elect. Inspiration is their prerogative, and the privilege of their public. Elsewhere the element of chance comes in. The possibility of inspiration belongs to all bodies of poetry, ancient and modern, but rather specially, I should say, to English. When we open a volume with which, old or new, we have had no previous acquaintance, we never can be sure that we shall not light upon, not indeed an inspired poet, but an inspired poem. Inspiration is like the wind ; it bloweth where it listeth.

A Church truth, it has been laid down, must be able to assert for itself that it is ' quod semper, quod ab omnibus, quod ubique, creditum est'. Much the same in the way of inspiration is required of a claimant to the laurel of poet. $\mathrm{He}$ is not obliged to prove that all he has written has been inspired. Very few, if any, could abide such a test; certainly not Wordsworth, Coleridge, Byron; not Shakespeare himself. The necessity is that the singer from time to time has been. For the waifs and strays the condition is reversed. Their readers have to feel that, however it may have been with the poet, inspiration is in the poetry. That strange quality which separates true poetry from all else has to be, and is, in it. We cannot define it; we can 
only explain it by its effects. It has, we know, at its birth, moved, perhaps transformed, the author. We feel that, for the moment, it has transformed us. No credentials are wanted, no illustrious name. Suddenly the words catch fire, and our souls with them.

The sense of mastery, of transport, of a kind of magic, is always the same. The occasion, the circumstances, the paternity and affinities of the visitant, when we try to account for its presence, differ as widely as Spenser from Pope, or Wordsworth from Byron.

Sometimes the poet had constantly been in the author of such verse, but asleep, torpid. A shock had awakened him ; it spent its force; and he sank back into lethargy or repose. Sometimes the piece represents the springtide of modest powers, a spasm of concentration of their essence, unintelligible to their owner. The writer's dominant impulse may have been other altogether than the curiosity of fancy. It may have been worldly ambition, or the enthusiasm of piety. A lever, a courser, has been sought to accomplish the craving of the ruling passion, and for the instrument verse has been requisitioned. Pure imagination's rival, rhetoric itself, will ever and anon force open in its flood a sealed well of pathos, heartache. Straightway we feel ourselves rapt from chill admiration into happy sympathy. Sometimes it is all an accident. A vision, a ghost, has stumbled upon a stranger lodged in the haunted room. Sometimes it simply has been that inspiration has been wandering after its manner in search of a home. Looking about for rest to the soles of its feet, it has taken refuge with no better than a versifier.

Poetry, from the time of its Elizabethan revival for some three-quarters of a century onwards, was in the air. A larger life had opened for Englishmen, freedom of soul, 
new ambitions, an expanse of art, learning, luxury. They had grown into lords to fit a larger world. A language for such a period was wanting; and many, scarcely comprehending the change in their utterance, found themselves poets. They sang because they could not help it, and were inclined to be ashamed of the impulse. It seldom occurred to them to claim property in their strains. Never, though they might court popular favour from the stage, did it enter their minds to adopt minstrelsy as their vocation.

In such a period one who, had he chosen to abandon other pursuits, could conceivably have qualified as a poet professed, for future generations, might write occasional verse comparable with that by recognized masters of the craft. The Lie, commonly, though not universally, attributed to Ralegh, is a succession of lightning flashes :

Say to the Court, it glows

And shines like rotten wood;

Say to the Church, it shows

What's good, and doth no good;

If Church and Court reply,

Then give them both the lie. ${ }^{1}$

No contemporary eulogy on Sidney surpasses his epitaph :

What hath he lost that such great grace hath won?

Young years for endless years, and hope unsure

Of fortune's gifts for wealth that still shall dure ;

0 happy race, with so great praises run $!^{2}$

His sonnet,

Methought I saw the grave where Laura lay, worthily introduced the Faerie Queene. His appeal in the Pilgrimage from his persecutors to Heaven is inspired, if ever verse was :

Blood must be my body's balmer ;

No other balm will there be given;

Whilst my soul, like quiet palmer,

Travelleth towards the land of heaven; 
Over the silver mountains,

Where spring the nectar fountains;

There will I kiss

The bowl of bliss ;

And drink mine everlasting fill

Upon every milken hill.

Then by that happy blissful day,

More peaceful pilgrims I shall see,

That have cast off their rags of clay,

And walk apparelled fresh like me,

I'll take them first

To quench their thirst

At those clear wells

Where sweetness dwells.

From thence to heaven's bribeless hall

Where no corrupted voices brawl;

No conscience molten into gold,

No forged accuser bought or sold,

No cause deferred, no vain-spent journey,

For there Christ is the king's Attorney,

Who pleads for all without degrees,

And He hath angels, but no fees.

And when the grand twelve-million jury

Of our sins, with direful fury,

Against our souls black verdicts give,

Christ pleads His death, and then we live. ${ }^{3}$

For sweet courtliness, if not for scientific accuracy, almost as much might be said of Wotton's address to the hapless Winter Queen :

You meaner beauties of the night,

That poorly satisfy our eyes

More by your number than your light,

You common people of the skies ;

What are you when the moon shall rise?

You violets that first appear,

By your pure purple mantles known

Like the proud virgins of the year,

As if the spring were all your own;

What are you when the rose is blown? 
So, when my mistress shall be seen

In form and beauty of her mind,

By virtue first, then choice, a Queen,

Tell me if she were not designed

The eclipse and glory of her kind ? ${ }^{4}$

How rich in melody an age must have been which could toss abroad, for Nicholas Breton, the singer of gay Phillida and Coridon-for anybody-for nobody-to claim, the pathos of a song like that on a love-child !

Thou little think'st and less dost know

The cause of this thy mother's moan;

Thou want'st the wit to wail her woe,

And I myself am all alone;

Why dost thou weep ? why dost thou wail ?

And know'st not yet what thou dost ail.

And dost thou smile ? O, thy sweet face !

Would God Himself He might thee see!

No doubt thou wouldst soon purchase grace,

I know right well, for thee and me;

But come to mother, babe, and play,

For father false is fled away. ${ }^{5}$

A great statesman, lawyer, philosopher, would at times sicken of ambition, even of wisdom; and out of the shadows may have flowed to and from Bacon's pen this bitter parable:

The World 's a bubble, and the Life of Man

Less than a span ;

In his conception wretched, from the womb

So to the tomb ;

Curst from his cradle, and brought up to years

With cares and fears.

Who then to frail mortality shall trust,

But limns on water, or but writes in dust.

Yet whilst with sorrow here we live opprest,

What life is best?

Courts are but only superficial schools

To dandle fools : 
The rural parts are turn'd into a den

Of savage men.

And when 's a city from foul vice so free,

But may be term'd the worst of all the three ?

Domestic cares afflict the husband's bed,

Or pains his head:

Those that live single take it for a curse,

Or do things worse ;

Some would have children : those that have them moan

Or wish them gone :

What is it, then, to have or have no wife,

But single thraldom, or a double strife?

Our own affections still at home to please

Is a disease :

To cross the seas to any foreign soil,

Peril and toil :

Wars with their noise affright us; when they cease,

We are worse in peace ;-

What then remains, but that we still should cry

For being born, or, being born, to die $!^{6}$

Dramatists who trusted to be immortal by their development of character, survive by rhymes they flung-in to employ some boy's tuneful voice. Thomas Dekker, indifferent on the stage, might be wholly dead but for the simple grace of :

Art thou poor, yet hast thou golden slumbers?

0 sweet content!

Art thou rich, yet is thy mind perplexed ?

0 punishment!

Dost thou laugh to see how fools are vexed

To add to golden numbers golden numbers?

$O$ sweet content! $O$ sweet, $O$ sweet content !

Canst drink the waters of the crispèd spring ?

O sweet content!

Swimm'st thou in wrath, yet sink'st in thine own tears ?

0 punishment ! 
Then he that patiently want's burden bears

No burden bears, but is a king, a king!

$\mathrm{O}$ sweet content! $\mathrm{O}$ sweet, $\mathrm{O}$ sweet content !

Work apace, apace, apace, apace ;

Honest labour bears a lovely face ! ${ }^{7}$

Webster and Shirley wrote great tragedies, few greater; yet they too, like Dekker, live in the hearts of men by their casual songs. Grand as is The Duchess of Malfy, I would lose the whole rather than:

Hark, now everything is still,

The screech-owl, and the whistler shrill,

Call upon our dame aloud,

And bid her quickly don her shroud !

Much you had of land and rent;

Your length in clay's now competent;

A long war disturbed your mind;

Here your perfect peace is signed.

Of what is't fools make such vain keeping ?

Since their conception, their birth weeping,

Their life, a general mist of error,

Their death, a hideous storm of terror.

Strew your hair with powders sweet,

Don clean linen, bathe your feet,

And-the foul fiend more to check-

A crucifix let bless your neck ;

'Tis now full-tide 'tween night and day;

End your groan, and come away. ${ }^{\circ}$

The damp of death is there. As we come across two of Shirley's songs-on death too-we seem to have emerged from a vault into the open air; and yet the pomp, the majesty!

Victorious men of earth, no more

Proclaim how wide your empires are;

Though you find in every shore,

And your triumphs reach as far 
As night or day,

Yet you, proud monarchs, must obey,

And mingle with forgotten ashes, when

Death calls ye to the crowd of common men.

Devouring Famine, Plague, and War,

Each able to undo mankind,

Death's servile emissaries are;

Nor to these alone confined,

$\mathrm{He}$ hath at will

More quaint and subtle ways to kill;

A smile or kiss, as he will use the art,

Shall have the cunning skill to break a heart.

How that, and the sister confession of the grave's supremacy, read like anthems of life and victory !

The glories of our blood and state

Are shadows, not substantial things ;

There is no armour against fate ;

Death lays his icy hand on kings;

Sceptre and crown must tumble down,

And in the dust be equal made

With the poor crooked scythe and spade.

The garlands wither on your brow;

Then boast no more your mighty deeds;

Upon Death's purple altar now

See, where the victor-victim bleeds;

Your heads must come

To the cold tomb;

Only the actions of the just

Smell sweet, and blossom in their dust. ${ }^{10}$

Shirley, though born too late, is Elizabethan in his singing temper. Death does not benumb him. Rather it challenges to a fight, in which defeat is no shame. That, more than Bacon's, or Webster's, is the true tone, the atmosphere which animates a dirge, if necessary, and, yet more willingly, love-carols.

How joyously fantastic the Elizabethans by choice are! 
How we feel that the singer is not singing for fame, or because he has the character of poet to support, but from mere gaiety of heart and wit! Lyly forgets his Euphuism, even in Cupid and Campaspe's game at cards for kisses, and yet more in his bird-song:

What bird so sings, yet so does wail ?

0 'tis the ravished nightingale.

' Jug, jug, jug, jug, tereu,' she cries,

And still her woes at midnight rise.

Brave prick song! who is't now we hear ?

None but the lark so shrill and clear ;

Now at heaven's gates she claps her wings,

The morn not waking till she sings.

Hark, hark, with what a pretty throat

Poor robin-redbreast tunes his note !

Hark how the jolly cuckoos sing,

'Cuckoo'! to welcome in the spring !

'Cuckoo'! to welcome in the spring! ${ }^{11}$

We cannot think of Thomas Lodge, but only of the inventory of his fair Rosaline's beauties :

Heigh ho, would she were mine!

or of the complaint against Love of equally fair Rosalynde, as we read her madrigal :

Love in my bosom like a bee

Doth suck his sweet;

Now with his wings he plays with me,

Now with his feet.

Within mine eyes he makes his nest,

His bed amidst my tender breast;

My kisses are his daily feast,

And yet he robs me of my rest ;

$\mathrm{Ah}$ ! wanton, will ye !

And if I sleep, then percheth he

With pretty flight,

And makes his pillow of my knee

The lifelong night. 
Strike I my lute, he tunes the string ;

He music plays if so I sing ;

He lends me every lovely thing,

Yet cruel he my heart doth sting;

Whist, wanton, still ye!

Else I with roses every day

Will whip you hence,

And bind you, when you long to play

For your offence.

I'll shut my eyes to keep you in ;

I'll make you fast it for your sin;

I'll count your power not worth a pin.

-Alas! what hereby shall I win

If he gainsay me!

What if $I$ beat the wanton boy

With many a rod ?

He will repay me with annoy,

Because a god.

Then sit thou safely on my knee;

Then let thy bower my bosom be;

Lurk in mine eyes, I like of thee;

0 Cupid, so thou pity me,

Spare not, but play thee ! 12

Love's music indeed is the most audible in the Occasional sixteenth-seventeenth-century verse; and it is in all keys. It is embodied daintiness in Carew's :

He that loves a rosy cheek,

Or a coral lip admires,

Or from star-like eyes doth seek

Fuel to maintain his fires. ${ }^{13}$

To grace it adds a sunny glow of passion, in Ford's :

Can you paint a thought? or number

Every fancy in a slumber?

Can you count soft minutes roving

From a dial's point by moving ?

Can you grasp a sigh ? or, lastly,

Rob a virgin's honour chastely? 
No, oh no! yet you may

Sooner do both that and this, This and that, and never miss,

Than by any praise display

Beauty's beauty; such a glory,

As beyond all fate, all story,

All arms, all arts,

All loves, all hearts,

Greater than those, or they,

Do, shall, and must obey ; ${ }^{14}$

and in that pretty foundling-if not Thomas Campion's or Richard Alison's-

There is a garden in her face

Where roses and white lilies blow;

A heavenly paradise in that place,

Wherein all pleasant fruits do grow;

There cherries grow that none may buy,

Till Cherry-Ripe themselves do cry ; ${ }^{15}$

It uses and idealizes Davenant's mannered extravagance:

The lark now leaves his wat'ry nest,

And climbing shakes his dewy wings.

He takes this window for the East,

And to implore your light he sings-

Awake, awake! the morn will never rise

Till she can dress her beauty at your eyes. ${ }^{16}$

It grows tumultuous in Love the Adventurer :

You may esteem him

A child for his might;

Or you may deem him

A coward from his flight;

But if she whom love doth honour

Be conceal'd from the day,

Set a thousand guards upon her,

Love will find out the way. ${ }^{17}$

It is at once defiant and tender in George Wither's :

Great, or good, or kind, or fair,

I will ne'er the more despair; 
If she love me, this believe,

I will die ere she shall grieve;

If she slight me when I woo,

I can scorn and let her go;

For if she be not for me,

What care I for whom she be ? 18

When it knows itself safe, it will threaten and hector :

Like Alexander I will reign,

And I will reign alone;

My thoughts did evermore disdain

A rival on my throne.

He either fears his fate too much,

Or his deserts are small,

That dares not put it to the touch,

To gain or lose it all.

But if thou wilt prove faithful then,

And constant of thy word,

I'll make thee glorious by my pen,

And famous by my sword;

I'll serve thee in such noble ways

Was never heard before;

I'll crown and deck thee all with bays,

And love thee more and more. ${ }^{19}$

Our poetry would not have been altogether shamed had it been able to support its title to share in Parnassus by none other than such casual blossoms as I have cited. It has the right to call in aid another contingent. There are European literatures in which folklore has played an important part. That scarcely holds in English, though I do not know why it should not have. There are noble exceptions. A high spirit of romance breathes through the patchwork, yet wholly chivalrous, Syr Cauline. ${ }^{20}$ The elder Chevy Chase, ${ }^{21}$ the subject of Sir Philip Sidney's qualified eulogium, ${ }^{22}$ deserves it all, and more. In general, I cannot in candour claim much for strictly English ballads. Those collected by Bishop Percy 
delighted our forefathers centuries ago. They continue, I hope, to be the delight of youth, as they were of mine. The Robin Hood series, the Nut-brown Maid, the Tanner of Tamworth, the Heir of Linne, the Beggar's Daughter of Bednall-Green, Mary Ambree, Brave Lord Willoughby, the Miller of Mansfield, and the like, are excellent reading; they are not poetry.

The impetus of the Elizabethan renaissance doubtless was felt north of the Tweed, as appears in the elegance, somewhat-even in the charming song, 'Phoebus! arise!' -over-learned and ingenious, of William Drummond's Muse. But for native Scottish imagination of the highest we must look to the Border Minstrelsy. The English version has no counterpart to the haunting dream of Earl Douglas in the Scottish tale of the Battle of Otterbourne :

I have dreamed a dreary dream,

Beyond the Isle of Sky;

I saw a dead man win a fight,

And I think that man was $I^{23}$

Everybody again must have felt both the woe and the power of the grand old ballad of Sir Patrick Spens. Note the Captain's knowledge that he was being sent to his doom, and his simple obedience; the instinct with which the few maritime details have been so chosen as to add as impressive reality to the impending disaster, as the many in the famous shipwreck in Don Juan; the narrator's splendid indifference to the fate of

The King's daughter o' Noroway,

in comparison with the loss of gude

Sir Patrick Spens, the best sailor

That ever sailed the sea; ${ }^{24}$

Then the lament for Willie Drowned in Yarrow-how touchingly wistful! 
Down in yon garden sweet and gay

Where bonnie grows the lilie,

I heard a fair maid, sighing, say

'My wish be wi' sweet Willie.

0 Willie 's rare, and Willie 's fair, And Willie's wondrous bonny;

And Willie hecht to marry me,

Gin e'er he married ony.

Oh, gentle wind, that bloweth south,

From where my love repaireth,

Convey a kiss frae his dear mouth,

And tell me how he fareth !

Willie 's gone, whom I thought on,

And does not hear me weeping;

Draws many a tear frae true love's e'e,

When other maids are sleeping.

0 came ye by yon water-side ?

Pou'd you the rose or lilie?

Or cam' ye by yon meadow green ?

Or saw ye my sweet Willie?'

She sought him up, she sought him down

She sought the braid and narrow;

Syne, in the cleaving o' a craig,

She found him drowned in Yarrow. ${ }^{25}$

It and the Dowie Houms of Yarrow are in their pathos and tragedy as admirable as the concert of great later melodies to which they have given birth. In the second observe the final reluctant acquiescence of the girl in the obligation upon her bridegroom to face the certainty of death at the hands of her jealous brethren. He has been challenged, and knows-and she knows-he may not hold back:

I maun gae, tho' I ne'er return

Frae the Dowie banks o' Yarrow.

She kiss'd his cheek, she kamed his hair,

As she had done before, 0 ;

She belted on his noble brand,

An' he 's awa to Yarrow. 26 
She was as brave in letting him go, as Helen of Kirconnell in interposing between the fatal shot and the lover she left despairing :

O Helen fair, beyond compare !

I'll make a garland o' thy hair, Shall bind my heart for evermair, Until the day I die !

O Helen fair ! O Helen chaste ! If I were with thee I'd be blest, Where thou lies low and taks thy rest,

On fair Kirconnell lea.

I wish I were where Helen lies ! Night and day on me she cries; And I am weary of the skies,

For her sake that died for me. ${ }^{27}$

The lamentation for 'burd Helen' is pure tenderness. More commonly in the Border minstrelsy there is a pathos which, instead of soothing, seems to intensify despair. In Clerk Saunders, for example, as in the Pot of Basil, the affection of the bereaved bride is agony, not grief. The lover's personal innocence does not alleviate his misery in the tragedy of the forlorn repulsed Lass of Lochroyan. Where remorse and pathos go hand in hand, guilt frequently forbids even the solace of a tear, as in the longing of fair Lady Anne to clasp to her bosom the 'snaw-white' dream-boy. It is her babe grown-up in Paradise, whom she had murdered to save her honour:

'Tis I wad clead thee in silk and gowd,

And nourice thee on my knee.'-

' $O$ mither! mither! when I was thine, Sic kindness I couldna see.' ${ }^{28}$

Gloom is the favourite hue, as was congenial perhaps in an age and land of Douglas Tragedies, Bonnie Earls o' Murray, and Johnie Armstrangs, where every man carried 
his own, and his over-the-Border neighbour's, life in his hand. Or it may be guilty wantonness, as in Earl Richard, ${ }^{29}$ and the grand ballad of the Daemon Lover. ${ }^{30}$ Still oftener it is sheer savagery, as in pitiless and unpitied Jellon Grame, ${ }^{31}$ Young Benjie, ${ }^{32}$ the wild, jealous scream of 'Binnorie, O Binnorie!' 33 and the astonished wail of The Queen's Marie. ${ }^{34}$ Sometimes it is a darkness which can be felt, a despair which would rejoice in the ache of remorse, as in Edward, Edward.

What an imagination it must have been that let loose upon the moorlands a vision of sardonic horror like that -

'Why does your brand sae drop wi' blude,

Edward, Edward ?

Why does your brand sae drop wi' blude,

And why sae sad gang ye ?'

' $O$, I hae killed my hawk sae gude,

Mither, mither ;

O, I hae killed my hawk sae gude,

And I had nae mair but he.'

'Your hawk's blude was never sae red,

Edward, Edward;

Your hawk's blude was never sae red,

My dear son, I tell thee.'

' $O$, I hae killed my red-roan steed,

Mither, mither ;

0 , I hae killed my red-roan steed,

That erst was sae fair and free.'

'Your steed was auld, and ye hae got mair,

Edward, Edward;

Your steed was auld, and ye hae got mair ;

Some other dule ye dree.'

' $O$, I hae killed my father dear,

Mither, mither ;

O, I hae killed my father dear,

Alas, and wae is me!' 
'And whatten penance will ye dree for that,

Edward, Edward !

Whatten penance will ye dree for that,

My dear son, now tell me ?'

'I'll set my feet in yonder boat,

Mither, mither;

I'll set my feet in yonder boat,

And I'll fare over the sea.'

'And what will ye do wi' your tow'rs and your ha',

Edward, Edward ?

And what will ye do wi' your tow'rs and your ha',

That were sae fair to see ?'

'I'll let them stand till they doun fa',

Mither, mither ;

I'll let them stand till they doun fa',

For here never mair maun I be.'

'And what will ye leave to your bairns and your wife,

Edward, Edward ?

And what will ye leave to your bairns and your wife,

When ye gang owre the sea ?'

'The warld's room; let them beg through life,

Mither, mither ;

The warld's room; let them beg through life;

For them never mair will I see.'

'And what will ye leave to your ain mither dear,

Edward, Edward;

And what will ye leave to your ain mither dear,

My dear son, now tell me.'

'The curse of hell frae me sall ye bear ;

Mither, mither ;

The curse of hell frae me sall ye bear ;

Sic counsels ye gave to me!' 35

Mark the shuddering ghost of the mother's knowledge that the parricide was inspired by her; the compulsion upon her soul to force her son to confess it; his reluctance to damn her with the avowal; and the curse upon herself which she extorts from his unlocked lips and heart! 
We are sensible almost of relief when the freezing cynicism is voiced by a couple of rivers, and not by man :

Tweed said to Till-

'What gars ye rin sae still ?'

Till said to Tweed-

'Though ye rin wi' speed

And I rin slaw,

Yet where ye drown ae man

I drown twa;' 36

or by the hoarse accents of carrion birds :

As I was walking all alane

I heard twa corbies making a mane;

The tane unto the t'other say,

'Where sall we gang and dine to-day?'

'In behint yon auld fail dyke,

I wot there lies a new slain knight :

And naebody kens that he lies there,

But his hawk, his hound, and lady fair.

His hound is to the hunting gane,

His hawk to fetch the wildfowl hame,

His lady's ta'en another mate,

So we may mak our dinner sweet.

Ye'll sit on his white hause-bane,

And I'll pick out his bonny blue een ;

Wi' ae lock o' his gowden hair

We'll theek our nest when it grows bare,

Mony a one for him makes mane,

But nane sall ken where he is gane;

O'er his white banes when they are bare,

The wind sall blaw for evermair.' ${ }^{37}$

Remember : the pieces I have mentioned are but specimens of a vast floating cloud of Border minstrelsy, with never a poet to claim for his own the inspiration, and the glory. The people's poetry-the ballads-in nine-tenths of England, by the end of the sixteenth century, which revised 
and vulgarized Chevy Chase, had lost all native sweetness, glamour, independent vitality. Meanwhile, in Scotland, throughout the Borderland, the whole survived and matured. The English Border, it may well be hoped and believed, if it contributed little-though the dialogue between the Tweed and the Till may be assigned to it-partook with its neighbours in the enjoyment. For some three hundred years, more or less, the popular literature of the region was verse. All was handed down from memory to memory, with a recognized right in the interpreters at each stage to modify, and, within narrow limits, modernize. How these wanderers told a tale, and with a variety how rich! How made to suit all tastes and classes! The minstrel might be earning food and shelter in a rustic inn, or sympathy and largess in the halls of high Buccleugh. Like the 'silly blind Lochmaben harper', 38 he had store of tales, humorous and pathetic, coarse and grisly. The merit was as diverse. From a very low point it rose to heights of sublimity, horror, tenderness, self-sacrifice, which educated inspiration may match, but rarely excels.

In England, though the old ballad literature had long lost its vigour, an afterglow of the cultured Elizabethan splendour endured to and throughout the period of the Restoration. It may be a mere coincidence ; but it faded away with the advent of reason, rights of citizenship, and full constitutionalism. English Poetry thenceforth consented to be conducted along regular professional channels. Its practice became a vocation, with its prizes in the book-market, and a tariff for the use and instruction of patrons. No longer was it winged, lodging where the whim took it. The emanation of anonymous verse of high merit ceased. I can find no trace of any. The little verse of distinction, not the work of writers already enrolled in my list of acknowledged poets, 
is by men better known in other departments of literature. Addison's Ode :

The spacious firmament on high, ${ }^{39}$

beats a stately march ; but it has, if a gleam of inspiration, nothing to spare.

Parnell, the author of The Hermit, in a gentle way, is a poet. A song of his is so neat as to suggest a doubt whether it may not be something higher :

When thy beauty appears

In its graces and airs

All bright as an angel new dropt from the sky,

At distance I gaze, and am aw'd by my fears,

So strangely you dazzle my eye !

But when without art,

Your kind thought you impart,

When your love runs in blushes through every vein;

When it darts from your eyes, when it pants in your heart,

Then I know you're a woman again.

There's a passion and pride

In our sex, she reply'd,

And thus, might I gratify both, I would do ;

Still an angel appear to each lover beside,

But still be a woman to you. ${ }^{40}$

In Isaac Watts's Cradle Hymn, I recognize real native inspiration, but inspiration doing suit and service to religious enthusiasm :

Hush ! my dear, lie still and slumber, Holy angels guard thy bed !

Heavenly blessings without number

Gently falling on thy head.

How much better thou'rt attended

Than the Son of God could be,

When from heaven he descended

And became a child like thee ! 
Was there nothing but a manger

Cursèd sinners could afford,

To receive the heavenly stranger ?

Did they thus affront their Lord ?

Soft, my child; I did not chide thee,

Though my song might sound too hard;

'Tis thy mother sits beside thee,

And her arms shall be thy guard.

Yet to read the shameful story,

How the Jews abus'd their King,

How they serv'd the Lord of Glory,

Makes me angry while I sing.

See the lovely babe a-dressing ;

Lovely infant, how he smil'd !

When he wept, the mother's blessing

Sooth'd and hush'd the holy child.

Lo, he slumbers in his manger,

Where the hornèd oxen fed-

Peace, my darling; here 's no danger,

Here's no ox a-near thy bed.

May'st thou live to know and fear him,

Trust and love him all thy days;

Then go dwell for ever near him,

See his face, and sing his praise ! ${ }^{41}$

There are lines by Shenstone in The Schoolmistress which have touched us all. I cannot pass by the best known of his 'Levities':

Whoe'er has travel'd life's dull round,

Where'er his stages may have been,

May sigh to think he still has found

His warmest welcome, at an inn. ${ }^{42}$

When a gust of pity or self-pity has blown rhetoric asiderhetoric still, though of a noble sort, as in London and The Vanity of Human Wishes-true inspiration takes its place, and Johnson marks with tears, instead of antitheses, 
what ills the scholar's life assail, Toil, envy, want, the patron, and the gaol. ${ }^{43}$

Or, mourning, with affectionate simplicity, almost with kindly envy, the obscurely wise, and coarsely kind practiser in physic, he

Sees Levet to the grave descend, Officious, innocent, sincere,

Of every friendless name the friend. ${ }^{4 t}$

Pieces like these are interesting as palliatives of a prevailing hungriness of the soil in respect of Occasional verse for some hundred years. There are things, like Mickle's Cumnor Hall, which habit and tradition endear. For positive poetical merit I do not know that I could instance more than a trio of pieces by writers of poetry who were not poets. Ambrose Philips for once carolled, as a songster of the grove for its nestlings, to his

Little gossip, blithe and hale, Tattling many a broken tale, Singing many a tuneless song,

Lavish of a heedless tongue, Simple maiden void of art, Babbling out the very heart, Sleeping, waking, still at ease, Pleasing without skill to please.

Yet abandon'd to thy will,

Yet imagining no ill,

Yet too innocent to blush;

Like the linnet in the bush,

To the mother-linnet's note

Moduling her slender throat;

Chirping forth thy petty joys,

Wanton in the change of toys ;

Like the linnet green in May

Flitting to each bloomy spray;

Wearied then and glad of rest,

Like the linnet in the nest. ${ }^{45}$ 
Then there is Henry Carey's Sally :

Of all the girls that are so smart

There's none like pretty Sally;

She is the darling of my heart,

And she lives in our alley.

There is no lady in the land

Is half so sweet as Sally :

She is the darling of my heart,

And she lives in our alley.

Of all the days that's in the week

I dearly love but one day;

And that's the day that comes betwixt

A Saturday and Monday;

For then I'm drest all in my best

To walk abroad with Sally;

She is the darling of my heart,

And she lives in our alley. ${ }^{46}$

In gaiety, flow and feeling at once sweet and sparkling, Sally, like Philips's verses on baby Charlotte Pulteney, transports us to an elder world. There is all the pride of youth, and the pathos of that pride besides.

What, finally, can I say that Robert Browning has not said already of Christopher Smart's ode to David :

A song where flute-breath silvers trumpet-clang ?

Born in a mad-house, whether does it prove that he had there first strayed from reason into inspiration, or that, by means of inspiration, he had at last recovered for a moment his genuine self ? I acknowledge a series of dazzling flashes revealing how

The world, the clustering spheres, He made;

The glorious light, the soothing shade,

Dale, champaign, grove and hill,

The multitudinous abyss,

Where Secrecy remains in bliss,

And Wisdom hides her skill. ${ }^{47}$ 
If I cannot help suspecting that a Browning's imagination is needed for much reading between the lines before affinity may plausibly be claimed for the Song :

\section{on either hand}

With Milton and with Keats,

I fully admit in a lesser yet high degree the wonder of the phenomenon. Such a flight-and then, not to 'die, but live', even sing !

How came it you resume the void and null, Subside to insignificance ! ${ }^{48}$

The Song of David, whatever its precise poetical rank, and however vehement the protest it raised against the correct and tame mediocrity of spirit in eighteenth-century verse, itself conformed to certain stiff and artificial canons. Thomas Warton, and, still more, Bishop Percy, had the courage to display impatience with the entire prevalent conventionalism. Percy both reminded his age of the old native poetic minstrelsy and challenged continuing lifea twilight life perhaps-for it, in his charming renovations of divers grand fragments. The poetic ferment was not, however, to be allayed by reminiscences of the past. It refused to be contented with anything short of a positive new poetic renaissance on both sides of the Tweed. It produced Burns in Scotland, as it had already produced Chatterton and Blake in England. It was preparing for the advent of Wordsworth, Coleridge, Scott, Byron, and Shelley.

Poetry, when it roused itself from its correctly tedious, slumberous torpor, towards the opening of the nineteenth century, woke into a new world. There is movement, with a sense of abundance of air. A poetic atmosphere, long since burnt up, is felt to have been renewed, for readers as well as 
writers. In Scotland it had been kept fresh below the surface of literature in the music which set the Muse of Burns dancing, singing, and loving. Now there, though no longer with the old grimly tragic accent, it grows distinctly apparent in Logan's welcome to the Cuckoo, and Braes of Yarrow, in the tender rustic melancholy of Auld Robin Gray, and the Land o' the Leal :

I'm wearing awa', Jean,

Like snaw when it's thaw, Jean,

I'm wearing awa'

'To the land o' the leal.

There's nae sorrow there, Jean,

There 's neither cauld nor care, Jean.

The day is aye fair

In the land o' the leal.49

Weird terror and despair have softened, risen, to resignation, even in the beautiful lament for Flodden-Field, and

The Flowers of the Forest a' wede away ; 50

even in the multitudinous, musical wail of regrets for Prince Charlie.

English writers who had never affected to be poets we find yielding to the new influence, and inditing lovely verse. Take for example Charles Lamb. He was scarcely aware he could write verse before he tried to divert his sister from mournful recollections by joining with her in a little volume of Poetry for Children. It is the ideal of books for the entertainment of the young by their elders, as is Louis Stevenson's Child's Garden the ideal one which might have been written by a child-inspired-for the entertainment of seniors. For the most part, charming as are things like The Magpie's Nest, Poetry for Children does not aspire to actual poetical honours. Yet the cxperiment taught Lamb, as in 
Nursing, which must be his, and in Hester, which he acknowledged, that he could sing.

How positive was the gift he has demonstrated in his farewell to the infant dying as soon as born:

Mother's prattle, mother's kiss,

Baby fond, thou ne'er wilt miss ;

Rites, which custom does impose,

Silver bells, and baby clothes ;

Coral redder than those lips

Which pale death did late eclipse;

Music framed for infants' glee,

Whistle never tuned for thee;

Though thou want'st not, thou shalt have them,

Loving hearts were they which gave them.

Let not one be missing; nurse,

See them laid upon the hearse

Of infant slain by doom perverse.

Why should Kings and nobles have

Pictured trophies to their grave,

And we, churls, to thee deny

Thy pretty toys with thee to lie ? ${ }^{51}$

His friend Wordsworth could not with a finer instinct have analysed departed Hester's nature, her joy which was pride, and her pride which was joy. I am only afraid he would have missed the tender humour in the sorrow:

My sprightly neighbour! gone before

To that unknown and silent shore,

Shall we not meet, as heretofore,

Some summer morning-

When from thy cheerful eyes a ray

Hath struck a bliss upon the day,

A bliss that would not go away,

A sweet forewarning ? 52

Again, how the air quivers with ghostly sighs as we read :

I have had playmates, I have had companions,

In my days of childhood, in my joyful school-days-

All, all are gone, the old familiar faces. 
I have been laughing, I have been carousing, Drinking late, sitting late, with my bosom croniesAll, all are gone, the old familiar faces.

I loved a Love once, fairest among women :

Closed are her doors on me, I must not see herAll, all are gone, the old familiar faces.

I have a friend, a kinder friend has no man :

Like an ingrate I left my friend abruptly ;

Left him, to muse on the old familiar faces.

Ghostlike I paced round the haunts of my childhood,

Earth seem'd a desert I was bound to traverse,

Seeking to find the old familiar faces.

Friend of my bosom, thou more than a brother, Why wert not thou born in my father's dwelling ?

So might we talk of the old familiar faces-

How some they have died, and some they have left me, And some are taken from me ; all are departedAll, all are gone, the old familiar faces. ${ }^{53}$

Proximity to verse like this provokes dangerous comparisons for any one. Certainly James Montgomery-whose World Before the Flood, Greenland, and Pelican Island, I read in boyhood, I confess, with admiration-cannot often stand it. Yet Lamb himself would not have scorned the melancholy grace of a Falling Leaf :

Were I a trembling leaf

On yonder stately tree,

After a season gay and brief,

Condemn'd to fade and flee;

I should be loth to fall

Beside the common way,

Weltering in mire, and spurn'd by all,

Till trodden down to clay.

Nor would I like to spread

My thin and withered face

In hortus siccus, pale and dead,

A mummy of my race. 
No-on the wings of air

Might I be left to fly,

I know not and I heed not where,

A waif of earth and sky !

Who that hath ever been,

Could bear to be no more?

Yet who would tread again the scene

He trod through life before?

On, with intense desire,

Man's spirit will move on ;

It seems to die, yet, like heaven's fire,

It is not quenched, but gone. ${ }^{54}$

Still less would Elia have disdained companionship with an English, if a humbler, Burns. I am almost afraid to let my heart go out to the Dorsetshire poet's The Wife a-lost, lest it should be the broad sweet dialect which has rocked my critical faculty asleep :

Since I noo mwore do see your feäce,

Upsteäirs, or down below,

I'll zit me in the lwonesome pleäce,

Where flat-boughed beech do grow ;

Below the beeches' bough, my love,

Where you did never come, An' I don't look to meet ye now,

As I do look at hwome.

Since you noo mwore be at my zide,

In walks in summer het,

I'll goo alwone where mist do ride,

Droo trees a-drippèn wet;

Below the rain-wet bough, my love,

Where you did never come,

An' I don't grieve to miss ye now,

As I do grieve at hwome. 
Since I do miss your vaïce an' feäce

In praÿer at eventide,

I'll prä̈ in woone sad vaïce vor greäce,

To goo where you do bide;

Above the tree an' bough, my love,

Where you be gone avore,

An' be a-waitèn vor me now,

To come vor evermwore. ${ }^{55}$

I have been perplexed where to class Sydney Dobell. The longer poems, The Roman and Balder, abound in fine passages. I find no false tone in the shorter, down to the posthumous sweepings of his writing-desk. Yet I doubt; and I know not exactly why. But I am sure that Balder's song, Laus Deo, on a loving widow's incapability-after 'seven long days and seven long nights' beside the open coffin - of measuring the wonder of bereavement by time:'On your lives!' she shriek'd and cried, ' he is but newly dead !'- ${ }^{56}$ deserves to be, and that Keith of Ravelston already is, among the Immortals :

The murmur of the mourning ghost

That keeps the shadowy kine,

' Oh, Keith of Ravelston,

The sorrows of thy line !'

Ravelston, Ravelston,

The merry path that leads

Down the golden morning hill,

And thro' the silver meads;

Ravelston, Ravelston,

The stile beneath the tree,

The maid that kept her mother's kine,

The song that sang she!

She sang her song, she kept her kine,

She sat beneath the thorn

When Andrew Keith of Ravelston

Rode thro' the Monday morn, 
His henchmen sing, his hawk-bells ring,

His belted jewels shine!

Oh, Keith of Ravelston,

The sorrows of thy line!

Year after year, where Andrew came,

Comes evening down the glade,

And still there sits a moonshine ghost

Where sat the sunshine maid.

Her misty hair is faint and fair,

She keeps the shadowy kine;

$\mathrm{Oh}$, Keith of Ravelston,

The sorrows of thy line!

I lay my hand upon the stile,

The stile is lone and cold,

The burnie that goes babbling by

Says nought that can be told.

Yet, stranger! here, from year to year,

She keeps her shadowy kine;

$\mathrm{Oh}$, Keith of Ravelston,

The sorrows of thy line!

Step out three steps, where Andrew stood-

Why blanch thy cheeks for fear?

The ancient stile is not alone,

'Tis not the burn I hear !

She makes her immemorial moan,

She keeps her shadowy kine;

Oh, Keith of Ravelston,

The sorrows of thy line ${ }^{57}$

I know no better example of the charm of reserve, of mystery, of half lights; as a forgotten poet has said, of the twilight interim,

When the gloom is soft, and the light is dim.

I find it equally hard to tell the permanent place of Christina Rossetti, Dante Gabriel's sister. Listen to Echo ; an echo of heart-music, of gladness 'how long ago' ! 
Come to me in the silence of the night;

Come in the speaking silence of a dream ;

Come with soft rounded cheeks and eyes as bright

As sunlight on a stream ;

Come back in tears,

O memory, hope, love of finished years. ${ }^{58}$

Ponder the cold, calm bitter-sweet of

When I am dead, my dearest,

Sing no sad songs for me ;

Plant thou no rosas at my head,

Nor shady cypress tree.

Be the green grass above me

With showers and dewdrops wet;

And if thou wilt, remember,

And if thou wilt, forget.

I shall not see the shadows,

I shall not feel the rain;

I shall not hear the nightingale

Sing on, as if in pain;

And dreaming through the twilight

That doth not rise nor set,

Haply I may remember,

And haply may forget. ${ }^{59}$

Read further ; and the difficulty of a just decision on the writer's rank will have grown :

Does the road wind uphill all the way?

Yes, to the very end.

Will the day's journey take the whole long day ?

From morn to night, my friend.

But is there for the night a resting-place ?

A roof for when the slow, dark hours begin.

May not the darkness hide it from my face?

You cannot miss that inn.

Shall I meet other wayfarers at night ?

Those who have gone before.

There must I knock, or call when just in sight ?

They will not keep you standing at that door. 
Shall I find comfort, travel-sore and weak ? Of labour you shall find the sum.

Will there be beds for me and all who seek ?

Yea, beds for all who come. ${ }^{.0}$

Sad that pathos is so easy ; sadder perhaps, that it is so fascinating, whencesoever it comes. Yet there is pathos which is just the bloom upon strength-a pathos other than Laetitia Barbauld's, though she wrote Life; than Felicia Hemans's, though she wrote Graves of a Household; a pathos akin to Wordsworth's, when he sang of LucyWhich is Christina Rossetti's?

By this time, almost unconsciously, I have advanced far into the nineteenth century. The progress is far more agreeable than in the eighteenth. As I proceed I experience, with happy recognition, a renewal of the surprises attending a survey of the Occasional poetry of the sixteenth and seventeenth. I keep wondering whence the inspiration came, why to this or that soul in particular, and why for this or that particular piece ;-how from the pile of Whittier's well-intentioned, tuneful, starless verse blazed forth Skipper Ireson's awakening to remorse for the desertion of his brother fishermen in a tempest !

'Hear me, neighbours!' at last he cried,-

'What to me is this noisy ride?

What is the shame that clothes the skin

To the nameless horror that lives within ?

Waking or sleeping, I see a wreck,

And hear a cry from a reeling deck!

Hate me and curse me,-I only dread

The hand of God and the face of the dead!'

Said Flud Oirson, fur his horrd horrt,

Torr'd an' futherr'd an' corr'd in a corrt

By the women o' Morble 'ead! 61

The ode to a Waterfowl-was it in Bryant's capable soul, 
or did it float to his pen from the air around, as, far on high, the bird to his sight?

Whither, 'midst falling dew

While glow the heavens with the last steps of day,

Far through their rosy depths dost thou pursue

Thy solitary way?

Vainly the fowler's eye

Might mark thy distant flight to do thee wrong,

As darkly painted on the crimson sky

Thy figure floats along.

Seekst thou the plashy brink

Of weedy lake, or marge of river wide,

Or where the rocking billows rise and sink

On the chafed ocean-side?

There is a Power whose care

Teaches thy way along that pathless coast,-

The desert and illimitable air,-

Lone wandering, but not lost.

All day thy wings have fanned,

At that far height, the cold thin atmosphere,

Yet stoop not, weary, to the welcome land,

Though the dark night is near.

And soon that toil shall end,

Soon shalt thou find a summer home, and rest,

And scream among thy fellows; reeds shall bend

Soon o'er thy sheltered nest. ${ }^{62}$

How mystically, strangely sweet, amid the beats, patriotic, rather than ethereal, of the Corn-law Rhymer's drum, rings the music :

Dark, deep, and cold the current flows

Unto the sea where no wind blows,

Seeking the land which no one knows.

Why shrieks for help yon wretch, who goes

With millions, from a world of woes,

Unto the land which no one knows?

Though myriads go with him who goes,

Alone he goes where no wind blows,

Unto the land which no one knows. 
For all must go where no wind blows, And none can go for him who goes ; None, none return whence no one knows.

Yet why should he who shrieking goes With millions, from a world of woes, Reunion seek with it or those ?

Alone with God, where no wind blows, And Death, his shadow-doom'd, he goes ; That God is there the shadow shows.

Oh, shoreless Deep, where no wind blows ! And thou, oh, Land, which no one knows! That God is All, His shadow shows. ${ }^{63}$

Whenever-as three centuries back, and, again, two later-the sun has dispersed the clouds about the peaks of Parnassus, it shines still, if fitfully, upon a curiously mixed crowd gathered at the foot. Particularly, in the course of, and consequent upon, last century's revival, it has been a bewildering assemblage, by virtue of its merits as much as of its defects. Education, reading, and a cultivated habit of good taste have made it difficult to distinguish clearly between genius and a golden mediocrity. The name of the poems able to set up a plausible claim to inspiration is positively legion. My task of discrimination among comparatively recent aspirants would have been much harder but for the skilful and sympathetic exertions of Mr. Quiller Couch in his admirable Oxford Book of English Verse. Sometimes the volume has brought one or another lyric for the first time to my notice. Often it has recalled excellence to my recollection.

In the multitude of candidates there are some who, well deserving admiration, have suffered from having, by accidents of fashion or curiosity, been brought into excessive notoriety. Such was Spanish Blanco White, whose sonnet 
on Night three-quarters of a century since, was, though in truth stately and noble, preposterously over-praised as the finest in the English language:

Mysterious Night! when our first parent knew

Thee from report divine, and heard thy name,

Did he not tremble for this lovely frame,

This glorious canopy of light and blue ?

Yet 'neath a curtain of translucent dew,

Bathed in the rays of the great setting flame,

Hesperus with the host of heaven came ;

And lo ! creation widened in man's view !

Who could have thought such darkness lay concealed

Within thy beams, O Sun ? or who could find,

Whilst fly, and leaf, and insect stood reveal'd,

That to such countless orbs thou madst us blind ?

Why do we, then, shun Death with anxious strife?

If Light can thus deceive, wherefore not Life ? ${ }^{64}$

There are too the real might-have-beens, as Hartley Coleridge, with more than one lovely song from his pen, like :

She is not fair to outward view

As many maidens be,-

to accuse him of spiritual suicide. There is Letitia Landon, hapless ' L. E. L.', with her Improvisatrice and Troubadour. There is Praed, who wrote the Red Fisherman, yet could not make up his mind, in a life of thirty-seven years, whether to vow himself to poetry or to politics. There is John Wilson-'Christopher North'-author of The Isle of Palms ; once arbiter of literary taste; and now as undeservedly neglected as he may formerly have compelled perhaps excessive deference. Beddoes is there; so is Horne, flinging his Orion at an unregarding public; with the two de Veres, Aubrey Thomas, a poet-soul content to have been born too late or too early, and his father, Sir Aubrey, of like genius and temper. Aytoun offers his Lays of the Scottish 
Cavaliers, with their resounding Burial March of Dundee. ${ }^{65} \mathrm{~A}$ numerous chorus of Hibernian patriots hurls its defiance at England, from the unknown author of Wearing of the Green :

She 's the most distressful country

That ever yet was seen;

They are hanging men and women

For wearing of the green!

$\mathrm{O}$ wearing of the green!

0 wearing of the green !-

to John Kells Ingram, improvising, in Memory of the Dead:

Who fears to speak of 'Ninety-Eight?

Who blushes at the name?

When cowards mock the patriot's fate,

Who hangs his head for shame?

He 's all a knave or half a slave

Who slights his country thus;

But a true man, like you, man,

Will fill your glass with us.

Amidst the enthusiasm and the wrath laughs the charming Irish humour in pieces like The Groves of Blarney, The Bells of Shannon, and I'm not Myself at All.66

Happy in the smoke of London Frederick LampsonLocker carols in many a dainty lyric; while Philip James Bailey finds this globe too narrow for the demands of his swollen Festus. Archbishop Trench is satisfied with grains of gold here and there, as in the spirited ballad of Harmosan, or as when he felt that the poetic spirit after long slumbering had revived in him :

And there was given me back the sacred gift of tears. ${ }^{67}$

Monckton Milnes deserves to be remembered for one song at least :

They seemed to those who saw them meet

The worldly friends of every day;

Her smile was undisturbed and sweet,

His courtesy was free and gay. 
But yet if one the other's name

In some unguarded moment heard, The heart you thought so calm and tame

Would struggle like a captured bird:

And letters of mere formal phrase

Were blistered with repeated tears,And this was not the work of days,

But had gone on for years and years! ${ }^{68}$

Some, though they failed of complete success, seemed like Robert Buchanan, author of Balder the Beautiful, with much besides, and like Edwin Arnold, in his Light of Asia, endowed with more than enough of developed qualities to have won the enduring sympathy they valued above all. Some, like William Ernest Henley, were cut off before their poetic prime. Some, like Jean Ingelow, needed perhaps only the spur of self-assertion to have climbed the heights. Others with less of it might have been more welcome below. Great intelligences are there, with every gift but the one-inspiration-coveted by them most; like Macaulay, whom the Muse pitied and rewarded once with a change of water into wine, of sonorous rhetoric into haunting poetry, as he pictures the mien of Tarquin's son, 'false Sextus,' in the Battle of Lake Regillus :

Men said he saw strange visions

Which none beside might see

And that strange sounds were in his ears,

Which none might hear but he.

A woman fair and stately, But pale as are the dead, Oft through the watches of the night

Sate spinning by his bed.

And as she plied the distaff,

In a sweet voice and low, She sang of great old houses, And fights fought long ago. 
So spun she, and so sang she,

Until the East was grey,

Then pointed to her bleeding breast,

And shrieked, and fled away. ${ }^{69}$

Others are like Louis Stevenson, who has shown in his Child's Garden of Verses that he might, had he so elected, have been recollected chiefly as a poet :

When at home alone I sit

And am very tired of it,

I have just to shut my eyes

To go sailing through the skies-

To go sailing far away

To the pleasant Land of Play,

To the fairyland afar

Where the Little People are;

Where the clover-tops are trees, And the rain-pools are the seas, And the leaves like little ships

Sail about on tiny trips;

And above the daisy tree

Through the grasses,

High o'erhead the Bumble Bee

Hums and passes.

Through that forest I can pass

Till, as in a looking-glass,

Humming fly and daisy tree

And my tiny self I see,

Painted very clear and neat

On the rain-pool at my feet.

Should a leaflet come to land

Drifting near to where I stand, Straight I'll board that tiny boat Round the rain-pool sea to float.

Little thoughtful creatures sit On the grassy coasts of it; 
Little things with lovely eyes See me sailing with surprise. Some are clad in armour greenThese have sure to battle beenSome are pied with every hue, Black and crimson, gold and blue ; Some have wings and swift are gone ;But they all look kindly on.

When my eyes I once again Open and see all things plain; High bare walls, great bare floor ; Great big knobs on drawer and door Great big people perched on chairs, Stitching tucks and mending tears, Each a hill that I could climb, And talking nonsense all the time-

$\mathrm{O}$ dear me, That I could be A sailor on the rain-pool sea, A climber in the clover-tree, And just come back, a sleepy head, Late at night to go to bed. ${ }^{70}$

Finally, if there be any finality, room, not much, has to be reserved at the roots of the mountain, even in these latter shyless days, for a few, a very few, modest 'Ignoti', such as one who last century cast on the waters the natural pathos of a Canadian Boat Song, with its cry of exiles yearning for their old loved home :

Listen to me, as when you heard our father Sing long ago the song of other shoresListen to me, and then in chorus gather All your deep voices, as you pull your oars !

From the lone shieling of the misty island

Mountains divide us, and the waste of seas-

Yet still the blood is strong, the heart is Highland,

And we in dreams behold the Hebrides ! 
We ne'er shall tread the fancy-haunted valley,

Where 'tween the dark hills creeps the small clear stream,

In arms around the patriarchal banner rally,

Nor see the moon on royal tombstones gleam.

When the bold kindred in the time long vanishèd

Conquered the soil, and fortified the keep,-

No seer foretold the children would be banishèd,

That a degenerate lord might boast his sheep.

Come foreign rage-let Discord burst in slaughter !

$\mathrm{O}$ then for clansmen true, and stern claymore-

The hearts that would have given their blood like water,

Beat heavily beyond the Atlantic roar.

Fair these broad meads, these hoary woods are grand:

But we are exiles from our fathers' land. ${ }^{71}$

'Ralegh, The Lie. Works, Oxford, 1820. (Poems) vol. viii.

2 Id., An Epitaph upon Sir Philip Sidney, ibid.

${ }^{3}$ Id., The Pilgrimage, ibid.

4 Wotton, To His Mistress, the Queen of Bohemia. Reliquiae Wottonianae, 1685, pp. 379-80.

${ }^{5}$ Nicholas Breton (A Sweet Lullaby). Works, ed. A. B. Grosart, 1879, vol. i. (Poems).

- Bacon, The Bubble. Reliquiae Wottonianae, pp. 397-8.

7 T. Dekker, H. Chettle, and W. Haughton, The Pleasant Comedy of Patient Grissil. Shakespeare Society, 1841.

${ }^{8}$ The Duchess of Malfy, Act iv, Sc. 2. Works of John Webster, ed. Alex. Dyce. 1857.

- Cupid and Death. Ode, 1653. James Shirley, Dramatic Works and Poems, ed. W. Gifford and A. Dyer. 1833.

10 The Contention of Ajax and Ulysses. Masque, Song, 1659. James Shirley, ibid.

11 Alexander and Campaspe. John Lyly, Dramatic Works, ed. F. W. Fairholt. 1858.

${ }_{12}$ Rosalynde, Euphues Golden Legacie. Thomas Lodge, 1878.

${ }^{13}$ Disdain Returned. The Poems of Thomas Carew, ed. Arthur Vincent. The Muses' Library, 1899.

14 The Broken Heart. John Ford, Works, ed. W. Gifford and A. Dycr. 1895. 
15 Thomas Campion. Fourth Book of Airs, 1617. Richard Alison, or Allison. An Howre's Recreation in Musike, 1606. (Anon., The Golden Treasury, F. T. Palgrave, p. 76.)

18 Sir William Davenant, Works, 1673.

17 (? Comedy by T. B.) Anon. Oxford Book of Verse, No. 391.

${ }^{18}$ G. Wither, Select Lyric Poems, ed. Sir E. Brydges. 1815.

${ }^{18}$ An Excellent New Ballad-to the tune of ' I'll never love thee more!' by James Marquis of Montrose. Memoirs of Montrose, by Mark Napier, vol. i, appendix, 34-5.

${ }^{20}$ Syr Cauline, ser. i, Book I, 4. Reliques of Ancient English Poetry, by Bishop (Thomas) Percy.

${ }^{21}$ The Ancient Ballad of Chery Chase. Ibid., ser. i, Book I, 1.

${ }^{22}$ Sir Philip Sidney, Miscel. Works, ed. W. Gray, 1829, Defense of Poesy.

${ }^{23}$ The Battle of Otterbourne (The Scottish Version), st. 19. Walter Scott's Minstrelsy of the Scottish Border, vol. i, pp. 354-62 (Rober: Cadell, 1833).

${ }^{24}$ Sir Patrick Spens. Ibid., vol. i, pp. 299-305.

${ }^{25}$ Willie's Drowned in Yarrow, stanzas 1, 2, 3, 8, 10, 11, pp. 25-7. Scottish Song, ed. Mary Carlyle Aitken. 1874.

${ }^{26}$ The Dowie Houms of Yarrow. Scott's Border Minstrelsy, vol. iii, pp. 147-50.

${ }^{27}$ Fair Helen. Ibid., vol. iii, pp. 103-5.

${ }_{28}$ Lady Anne, st. 8. Ibid., vol. iii, pp. 21-2.

${ }^{29}$ Earl Richard. Ibid., vol. iii, pp. 184-90.

30 The Daemon-Lover. Ibid., vol. iii, pp. 195-8.

s1 Jellon Grame. Ibid., vol. iii, pp. 164-7.

32 Young Benjie. Ibid., vol. iii, pp. 13-17.

s3 The Cruel Sister (Binnorie, O Binnorie). Ibid., vol. iii, pp. 289-93.

34 The Queen's Marie. Ibid., vol. iii, pp. 298-304.

${ }^{35}$ Edward, Edward. 'A Scottish Ballad. From a MS. copy transmitted from Scotland.' Ser. i, Book i, 5, Percy's Reliques (I have somewhat anglicized the Scotch spelling in Percy's copy.)

${ }^{36}$ Anon. Scottish Rivers, Sir Thomas Dick Lauder, p. 198 (Edmonston \& Douglas, 1874).

32 The Twa Corbies. (Scott's Border Minstrelsy), vol. ii. pp. 359-60. (W. Motherwell's version, Minstrelsy, Ancient and Modern, 1827, varies.)

${ }^{38}$ The Lochmaben Harper. (Ibid.), vol. i, pp. 422-6.

39 Joseph Addison, Ode. (Johnson's Poets, vol. xxx; p. 227.)

«o Dr. Thomas Parnell, Song. (Johnson's Poets, vol. xxvii, p. 14.) 
"1 A Cradle Hymn, Dr. Isaac Watts. (Johnson's Poets, vol. lvi, pp. 240-2, stanzas $1,3,6,7,8,10,11,13$.)

"2 Written at an inn at Henley, st. 5. Shenstone's Poems (Johnson's Poets, vol. lix, p. 186).

${ }^{43}$ The Vanity of Human Wishes. Works by Samuel Johnson, 2 vols. (H. G. Bohn, 1850), vol. ii, p. 93.

${ }^{44}$ On the Death of Mr. Robert Levet, a Practiser in Physic, st. 2, ibid., vol. ii, p. 85.

${ }^{45}$ Ambrose Philips-To Miss Charlotte Pulteney, in her Mother's Arms, May 1, 1724. (Johnson's Poets, vol. lvii, p. 74.)

${ }_{46}$ Sally in our Alley, stanzas 1 and 4. Henry Carey, Poems, 1729.

${ }^{47}$ Christopher Smart. A Song to David, st. 5. Works and Life, 1791.

${ }^{4}$ R. Browning. Parleyings with Certain People. (Christopher Smart), vi, p. 85.

'9 Carolina Lady Nairne. The Land o' the Leal. Poems, with Memoir, ed. Charles Rogers, 1869.

${ }^{50}$ The Flowers of the Forest. Jane Elliot. (Scott's Border Minstrelsy), vol. iii, pp. 335-7.

${ }^{51}$ On an Infant Dying as soon as born, p. 184. Poetical Works of Charles Lamb. Fourth Edition, H. G. Boln, 1841.

${ }_{52}$ Hester, pp. 1-2. Ibid.

${ }^{33}$ The Old Familiar Faces, pp. 15-16. Ibid.

${ }^{5}$ The Falling Leaf. The Poetical Works of James Montgomery. Longmans, 1850 , p. 321.

${ }^{55}$ The Wife A-lost, pp. 155-6. Poems of Rural Life-in the Dorset Dialect-by William Barnes. Second collection. F. R. Smith, 1863. ${ }_{56}$ Balder (Song), vol. ii, pp. 198-202. Poetical Works of Sydney Dobell, ed. J. Nichol. Smith, Elder \& Co., 1875.

${ }^{57}$ A Nuptial Eve (Keith of Ravelston), ibid., vol. i, pp. 372-3.

${ }^{68}$ Echo, st. 1, Christina Rossetti, p. 80. Goblin Market and Other Poems. Macmillan, 1865.

${ }^{69}$ Song, ibid., pp. 110-11, ibid.

${ }^{\circ}$ Uphill, ibid., pp. 128-9, ibid.

${ }^{61}$ Skipper Ireson's Ride. John Greenleaf Whittier, st. 8, pp. 274-6. Poetical Works. Macmillan, 1874.

${ }^{62}$ To a Waterfowl. William Cullen Bryant (Poems, Collected by the Author. Liverpool, 1850).

${ }^{63}$ Plaint. Ebenezer Elliott. More Verse and Prose by the Cornlaw Rhymer, vol. i, pp. 11-13. C. Fox, 1850.

${ }_{64}$ To Night. Joseph Blanco White. Life, by Himself. Ed. J. H. Thom, 1845. 
65 The Burial-March of Dundee, pp. 107-16. Lays of the Scottish Cavaliers, by William Edmondstoune Aytoun. Blackwood, 1856.

${ }_{68}^{68}$ The Wearing of the Green. Anon., p. 515. The Memory of the Dead, John Kells Ingram, pp. 63-4. The Groves of Blarney, R. A. Milliken, pp. 437-8. The Bells of Shandon, Francis Mahony, pp. 431-2. I'm not Myself at all, Samuel Lover, pp. 349-50. Irish Minstrelsy, by H. Halliday Sparling. W. Scott, 1888.

67 Harmosan, pp. 228-30, and To Poetry, st. 6, p. 282, and Richard Chenevix Trench. Story of Justin Martyr and Other Poems. Parker \& Son, 1862.

${ }^{68}$ Shadows, Il. Selections from the Poetical Works of Richard Monckton Milnes, Lord Houghton. John Murray, 1863.

${ }^{69}$ Lays of Ancient Rome (The Battle of Lake Regillus), Thomas Babington Macaulay. Longmans, 1842.

70 Stevenson, The Little Land (A Child's Garden, IX, pp. 51-3). Works of Robert Louis Stevenson. Longmans, 1895.

${ }^{71}$ Canadian Boat Song (see G. M. Fraser, Times Literary Supplement, Dec. 23, 1904, where it is mentioned that the song has been attributed variously to Professor Wilson, Lockhart, John Galt, and Lord Eglinton). 


\section{CONCLUSIONS?}

From my first to my latest words on verse which is poetry, though, it may be, without a poet, I have had in my mind two questions. Consciously or unconsciously I have been asking myself : 'What then is Poetry ?' and 'What makes a Poet ?' I am unable to answer them yet to my own satisfaction.

I can enumerate the qualities which, single or several, never all together, unless perhaps in one superhuman case, I myself find in English verse. Fancy and Imagination, Form--or Style-, Stateliness, Passion, Charm, Mystery, Pathos, Atmosphere, and Spontaneity share among them whatever poetry is, in my judgement, entitled to be called great. Imagination and Fancy stand foremost; Imagination for the processes of reconstructing, anticipating, and prophesying ; of setting Fancy in motion ; Fancy, whether independently, or, after Imagination has done its work, and sometimes before, for seeing things under a changed aspect, the old as if they were new.

The absence of Form is more readily noted than its presence. When the distinguishing characteristic, as of Ben Jonson as poet, of Herrick, Waller, Suckling, and Lovelace, it is almost identical with Style. It implies Selfrestraint, and Reserve. Frequently it has the happiness to be associated with too much of grandeur for it to be singled out as the writer's badge. Yet a poet may be illustrious without it; for Wordsworth is.

Stateliness and Passion, necessities sometimes, otherwise are often out of place. We want no finer example of the former than Paradise Lost, and no worse than Night 
Thoughts. For Passion take Shelley. At his best he achieves to perfection the self-abandonment, the ecstasy, which is the triumph of poetic art.

Charm in poetry every one feels, none can explain. It alters its hues to each reader's eyes. Analyse it, and the hand grasps air. It comes at nobody's beck and call; not even Milton's or Shelley's. Commonly, by no means always, it turns its back upon Wordsworth. It will not be parted from Herrick and Keats.

Mystery is a rare visitant, and welcome only when rare. It is among the distinctions of Christabel. It is the glory of Webster's weird execution-dirge ; of Scottish 'Edward, Edward'; of Sydney Dobell's Keith of Ravelston. It is Edgar Allan Poe's prime engine, and his Evil Genius.

None can speak of Pathos as any longer shy and retiring. Of old it was little used. Not unknown among the Elizabethans, it was with them far from habitual. In later days it is its absence which would be remarkable. Both writer and critic are apt to find it a dangerous snare. They are liable to be bribed by it to accept their own heart-beats for music of the spheres. I hope I have already sufficiently warned my readers that they are free to discount my praises of verse whenever they themselves are inclined to shed a tear over it. In a poet to aim at pathos, scheme for it, is criminal. When it comes it should come as an incident, not as the motive, or calculated result. In great poetry, as Wordsworth's, it steals forth almost, as it were, against the poet's will.

I have left to the end a couple of qualities, which are not so much separate properties of poetry, as conditions or states of it. Each I regard as exceedingly precious. When we are not sure that we have learnt from a poem all which is to be learnt, that we have felt all which is to be felt, 
when we suspect that it holds in reserve for us delightful possibilities, that it has entered into us, and that we are in spiritual unison with it-then and there $I$ recognize Atmosphere. It is not a beginning or a basis, but a result. When the feast is over a box of spikenard is broken; and a fragrant vapour envelops all. Blake's verse floats in Atmosphere. So does Keats's Eve of St. Agnes. So Christabel. There is Atmosphere in Hogg's Kilmeny. I find none in Campbell, and little in Scott's own verse, though abundance in his Border Minstrelsy.

Akin to it, I suppose, though the state is as hard to describe as Atmosphere, is every supreme poet's and poem's strange power suddenly to open fresh sources in brain and heart. Forthwith issues a flood of feeling as magically sweet to reader as to writer. A mere versifier may go up and down, sinking wells everywhere. He tortures the depths of the soil. The entire region remains for him a desert, a Sahara. The poet comes with his willow bough ; and springs gush from the solid rock to meet the divining rod as it bends. It is a real gift, like the spell, the touch on human eyes, which used to reveal the coexistence with this earthy world of ours of actual FairyLand. I have named the condition for want of a better word, Spontaneity ; for its effects have no manifest cause. Really spontaneous generation is as unknown in poetry as in physics. Fancy sows the germs, and forgets where. They, when sprung-up, remember, and, after wandering away, return, as birds to their nesting-places. Nobody can tell the precise nature of the agent, whether it be a thing, or a power, a mode of action, an aspect of something else. It roams about the realm of poetry, lending itself out to this or that separate quality. Pomp at its touch becomes majesty. Charm rises everywhere, like 
a floweret of the soil. Chimes from invisible belfries peal through the midnight air. The long dull story of poor Simon Lee blossoms into pathos.

I have often thought what a surprise to the poet himself must be this investiture of the children of his brain with trailing clouds of glory, whence voyaging he knows not; the apparition among the creations for which his imagination had sorely laboured, of angelic beings as strange to him as the companion of the three Hebrews in the fiery furnace to the Chaldean King. Inspiration works no greater miracles than with its Spontaneity, and also with its Atmosphere.

Other qualities besides all those I have mentioned doubtless might be valuable in verse, if present. For example, there is Unselfconsciousness, a real virtue; only, I do not happen to have met with it in English poetry, outside Shakespeare's Plays. There is Surprise, which-not very rarely-does occur, as in the thrilling transition in Herrick's Daffodils from pity for the fleeting beauty of a flower to a call of universal creation to prayer :

\section{Stay, stay}

Until the wasting day

Has run

But to the evensong;

And having prayed together, we

Will go with you along.

The properties I have been describing distinguish poems when composed. Before they came to their birth the poet must have undergone the influence of his period. Few besides Milton in his chief work, if he entirely, and Keats in all of his, have escaped a close relation to their age and its essential characteristics. The rule is for poetry to belong to its time. Its propensity is to express ideas, 
capable of true expression only in poetry, which have been born of that time. The taste and fashion of the period may have changed and been forgotten. The spirit, if ever it were real and sincere, will, though tinged with the colours of its age, continue to live in literature. It may even burst anew into flame. If the period as a whole, or any distinct stratum in it, accepted as its voice a poet it had formed, he will remain a voice, though echoing from a wilderness. In any event he and the public which once listened to his music will have had to a large extent a community of soul.

Bacon has been argumentatively fabled to be the actual Shakespeare. It is a fraction of the truth. He must share the fellowship with Ralegh and Drake, Essex, the Cecils, the wits of the Mermaid, Sidney, Spenser, the buccaneer-mariners of Devon-with the entire awakened nation. All were together joint authors with Shakespeare of the Plays, and of many a famous poem for a half-century besides. Every author more or less, a poet most of all, represents his environings. The character of poetry always depends largely upon the personal element, on the natures of the readers as well as on that of the poet. Warmed by the same sunshine, and buffeted by the same storms as they, he gives back to them their own in song. When we admire the antique without being able to give a reason for our admiration, it often is that insensibly we have lived back into another age by virtue of communion with one of its creatures and creators. The blood of a distant era is stirring in us.

It is not always direct sympathy with a period which sets natures poetically endowed singing to their generation. Sometimes it is an analogous emotion in a contrasted guise-a temper of revolt, the attraction of antipathy. A minority has persuaded itself that the scene ought to be 
shifted. Herbert and Vaughan were inspired to protest against the manners of their time on behalf of Heaven. Later on, from the same disgust at the present, Cowley augured triumphs for science still unborn, but in the air. Samuel Butler mocked despotic Puritan Major-Generals. Dryden championed reaction, political and theological. Swift was jaundiced against a world as petty as Lilliput, and as coarse as Brobdingnag. Pope's spitfire, cynical indifferentism inspired itself with the social miasma it affected to loathe. Burns's Muse wavered between joy in Arcadian simplicity and an uneasy, a remorseful, rebelliousness against Kirk Sessions-perhaps, against family Saturday Nights themselves. Byron's defiance of his fellowmen, Browning's disquisitions to society on the meaning it had forgotten of its own vagaries, and Tennyson's efforts to tempt it into becoming the ideal of its distorted, distracted self, are all alike steeped in the time's circumstances. Their public recognized itself-denounced, compassionated, moralized, etherealized-as their theme. Each popular singer in turn has believed himself a leader and a prophet. So he has been; but a leader, because most obediently representative of his followers; a prophet, because best translating the inclinations of his disciples by his own. Elizabethan grandeur and spaciousness reflect themselves in the giants of contemporary poetical literature. It is the same with the earthiness, the intellectual and spiritual poverty, of three-fourths of the eighteenth century. Every period craves to have itself poetically interpreted, though the lyre rasps and creaks. When it is without Jonsons and Herberts, and cannot commission enough Grays and Goldsmiths, it must perforce put up with Youngs and Akensides. In any case it longs to feel akin to the minstrelsy. A poet bows to the same instinct. His song, 
whether in defiance, or response, was nursed in, and would return to, the hearts to which he sings.

Great poetry has characteristics, its very own. No less it indicates the special circumstances of its origin. The authors disguise themselves as little. They, with their respective tendencies and energies of all sorts, for the most part mirror themselves, and have their being, in their verse. Strongly marked and vigorous in the main features, with failings as self-evident, that being is bound to be. The Muse does not take her priests and prophets at random. In the elect we have a right to expect intrinsic power, the sense of a natural title to the crowns placed on their heads. The assurance is superior to silence, to neglect. Though posterity may have forgotten, their royalty is indefeasible. The substance, material and spiritual, adopted by the poetic spark for its lodging, or home, ought to be selfsufficing. It should be able to entertain the guest, and survive with dignity its departure. Survey the dynasty of sovereign British poets to whom successive generations have paid homage. Beyond dispute nine-tenths will be admitted to have been not less remarkable as men than as poets ; to remain remarkable when they have ceased to sing.

Genial Chaucer rises at my invocation, soldier, ambassador, and courtier, cheerfully careless of prelate's or friar's scowls. I see Spenser with the key to fairyland, a statesman also, almost single in appreciation of the national need to cut at the root of the Irish problem, though the ruthlessness of his policy shocks me. I see Shakespeare shrewd in affairs to a degree supposed to be incompatible with an angelic fancy. Milton stands forth, the unrivalled controversialist, when, for his period, aged; unsubdued by blindness and persecution. Dryden, though speaking very terrestrial thoughts, succeeds to the throne as by right divine. Pope, 
ever on the brink of the grave, with the vigour of immortal youth drives his battle-car over ranks of venomous, prostrate poetasters. Cowper, combating the melancholy madness in his blood, is fighter and seer, as well as martyr. Burns was a man, if with a full share of man's weaknesses ; nobly planned by nature, lord of his company, whatever the company might be. Know Scott in his home; and you know Scott the poet; great in prosperity, greater in adversity. Wordsworth as poet had simply to translate into song his ideal of human duty. Coleridge, had he never written a line of verse, would have equally fascinated his Court. Byron, while making, alas! the music, had at all events the courage to face it. What a glorious instrument was Shelley, had the world but learnt how to play upon it! An apparent exception to the rule, Keats himself, we know now, was no mere dreamer; not at all of the kind to be snuffed out by a peevish reviewer, had physical vigour but matched imagination. And what, lastly, of the latest lords of Parnassus, Tennyson and Browning? Vast native intelligences, cast in different moulds, but equally from youth vowed to poetry-both given to labours enough to break a ploughman's back-pitted against one another by emulous partisans, yet never by a word accepting antagonism-never, to all seeming or guessing, susceptible of a jealous suspicion!

Nature would have been cruel had she not equipped with manifold sturdiness those selected to hand the torch of inspiration from one generation to another. The poetic spirit is well advised in preferring to house in a big nature. The vocation of poet is among the most uncertain, the thorniest. With some verse, it is true, we find it difficult to associate the thought of toil. The writer might have

lisped in numbers, and the numbers came. 
We do not know how into Lamb's pen, which loved to run, like the Mole, underground, his few and lovely strains flowed. In general, however, the arduous character of the pursuit is indisputable. Never could fancy apparently have been more spontaneous than Goldsmith's; and he worked on a poem for years. The start for any writer may have been easy, a supply of imagination and fancy being presupposed. Very soon basking in the sun has to turn into delving and digging. The raw materials with which the poet deals, often are waiting in readiness for him; but he has to manufacture them. The thoughts and feelings he has to express are common to human nature; but they are inarticulate until he has educated language, without external evidence of compulsion, to discover unknown capacities in itself for constituting it their voice. During the process, and as a condition of its success, all his energies are in a state of effervescence. Meanwhile, he has to look for the spirit to descend, and call a soul into being. For long probably there is no result. At length, not apparently out of the steam and bubbling, a shape becomes visible. A necessary characteristic of any poetry worthy of the name doubtless is that the work, as the reader, perhaps as the worker, sees it, shall bear upon its face no evidence of the pains it has cost. Not the less is it the fruit of a protracted and vehement course of spiritual gymnastics ; frequently of agony.

Courage, curiosity, patience, obstinacy, egotism, selfreliance, perhaps a spice too of self-conceit, all are wanted for the struggle against adversaries at home and abroad. The poet must have a will. He must insist on being blind and deaf to the claims of rival faculties; of his own, when inspiration is on him. They must even let themselves be harnessed to its chariot. Lack of doggedness in breaking-

voL. II

C c 
in counter intellectual and spiritual impulses, in obliging them to serve, has often smothered the poet under the philosopher or critic. A trial yet more afflicting is the duty of being master in his own house, to the self-torturing extent of setting bounds to the flights of his Queen, his Genius, his Inspiration itself; of imposing silence, of seating reason above ecstasy. All the time the world outside may act as though resentful of his mere existence. Having suffered his Muse, Medea-like, to toss him into the boiling cauldron, he issues forth, believing himself adorable. He sallies out in the cold, rain, storm, and darkness to woo the public with guitar and serenade, as if it were a loving mistress. He finds himself a butt for insolent ridicule, when, absorbed in his ideas, carried away by a prophetic rapture, he dances, like David, before the Ark. He must steel himself to bear persecution because he is honest, chill surprise when he is sublime, contempt when he announces to his age novelties which will be truisms for the next !

In the long and illustrious line scarcely a single member has not had to grope his way to renown through stifling fogs of prejudice. Nature seldom models any for poets without adding extreme sensitiveness to outside opinion. They have to pretend not to care. Some stumble outright on the course. There have been

mighty Poets in their misery dead.

The immediate prizes at best are few, with hundreds to compete. Many are the early failures of ultimate winners. Almost more disheartening are the half-successes, like the fringe of a rain-cloud in a drought. Moore may have felt the ache when he found that his Melodies were not the forerunners of a great poem. Absolute triumphs themselves have their drawbacks in misapprehensions by popular 
enthusiasm of the real point and motive. Verily, as I take a bird's-eye view of the poetical hierarchy, with its perils and temptations, I am not surprised at the general coincidence of toughness, physical and mental, with inspiration in the few of its members who, in any age, stay out the race to the end.

A 'general', not universal, coincidence, I repeat-and the same qualification must be introduced whencver an attempt is made to imprison poetry and poets inside an absolute definition. I have tried the experiment with an enumeration of essential properties, as they might seem, belonging to whatever poetry is genuine. It has always failed, even down to the specification of metre itself as indispensable. None will deny that Ruskin constantly sings in prose, and De Quincey frequently. Shelley could be as musical in an essay as with his Skylark. I know of a sentence which is poetry in Hallam, an author as habitually unpicturesque as his own Wimpole Street. I have my doubts about a piece of Plantagenet portraiture in tough Bishop Stubbs. Though I cling to the belief that imagination and fancy are, one or both, necessary to true poetry, I should not care to dogmatize on it. Charm, I am sure, ought to be ; and is not. With the splendour of the Ode on the Passions confronting me, I can lay down no law of an inevitable relationship of sentiment in great poetry to its period and country. While I am fully persuaded of the especial convenience of the union of moral and physical strength with the poetical temperament, I shrink from going further. Were $I$ to pronounce the marriage indissoluble, I might expose myself to an immediate dilemma of having to choose between eating my words and the rejection of a masterpiece.

The utmost of certainty I possess is that, as I have many c c 2 
times intimated, the soul has moods, emotions, ideas, which, were there no such thing as poetry, would probably never have come into active, visible existence. As there is, they exist, yet, in default of poetry, would remain, for most of us, as if they were not. Poetry, whatever in its origin and essence it may be, proves its being by furnishing expression for them. For the purpose, it takes ordinary speech. Having by some strange, untraceable process of spiritual chemistry, which we call Inspiration, fused with it the mute spiritual germs, it introduces the amalgam into the common mind. Thereupon emotions, ideas, moods cease to be dumb ; and language swells into the diapason of an organ.

Without the poets innumerable phases of the soul, many of them among the highest, would never have come to life, completely, if at all. Eternal gratitude is their due, and, on the whole, is, I dare say, adequately rendered to the acknowledged princes of song. Candidates struggling upwards to the light receive hard measure. It appears to be considered that the ignominy of defeat in poetry ought to be pro. portionate to the possible, the rare, glory. Failures in prose are liable usually, as I know, to no more condign penalty than neglect. Poets, unless they be crowned, are never safe from the pillory. They enter the lists at the peril of the doom threatened to law reformers in the old Greek State. In equity they well might plead that their critics ought equally to abide the risk. For myself $I$ am fully conscious how fair the claim would be, and sincerely trust that $I$ have behaved as if $I$ were. Throughout $I$ can assert that, in venturing to assume the critical character, I have had a constant sense of a cord round my own neck instead of the poet's. I have even felt a lively apprehension that the noose might be tightened by the thick fingers of some Georgian poet's ghost. For their own sakes, 
no less than for that of the public, members of the profession, in which for my present purpose I have enrolled myself, are bound, I believe, to be always on the watch that they do not bar entrance within the temple of the Muses to angels unawares. Continually they should be reminding themselves that aspirants vainly seeking admittance in the despised guise of Minor Poets have been discovered ere this to be meditating poetry which is Great. 



\section{INDEX OF POETS}

WITH DATES OF BIRTH AND DEATH

ADDISON, JosEPH (1672-1719).

ARNoLD, EDWIN, Sir (1831-1904).

ARNOLD, MATTHEW (1822-1888).

Aytoun, William Edmonstoune, Professor (1813-1865).

Bacon, Frascis, Viscount St. Albans (1561-1626).

Bailey, Philip James (1816-1902).

BarbaUld, ANNA Letitia, Mrs. (1743-1825).

Barnes, William, Rev. (1801-1886).

Beddoes, Thomas Lovell (1803-1849).

BRETON, Nicholas (1545 ?-1626?).

Browning, Elizabeth Barrett, Mrs. (1809-1861)

Browning, Robert (1812-1889).

Bryant, William Collen (1794-1878).

BuchaNAN, ROBERT (1841-1901).

Byron, George Gordon NoEI, Lord (1788-1824).

Campion, Thomas, (1567?-1619, or 1623).

Carew, Thomas (1598?-1639?).

CAREY, HeNry (1696 ?-1743).

Clovgh, Arthur Hugh (1819-1861).

Coleridge, Samuel Taylor (1772-1834).

Davenant (or D'Avenant) William, Sir (1606-1668).

DEKKER, Thomas (1570?-1641 ?).

DoBELL, SydNEY Thompson (1824-1874).

DRUMmond, William, of Hawthornden (1585-1649).

Elliot, Jane (Jean) (1727-1805).

Elliott, Ebenezer ('The Corn-law Rhymer') (1781-1849).

EMERSon, RALPH WALDo (1803-1882).

FitzGerald, Edward (1809-1883).

Ford, JoHN (1586 (baptized)-1639 ?).

Hemans, Felicia Dorothea, Mrs. (1793-1835). 
Henley, Wrlliam Ernest (1840-1903).

HogG, JAMES (1770, or 1772-1835).

Hood, Thomas (1799, or 1798-1845).

Horne, Richard Henry (or Hengist) (1803-1884).

Hunt, James Henry Leigh (1784-1859).

INGELOW, JEAN (1820-1897).

INGRAM, JoHN KELLS, LL.D. (1823-1907).

Johison, SAMUEL, LL.D. (1691-1773).

KEATS, JоHN (1795, or 1796-1821).

KeBLE, JoHn, Rev. (1792-1866).

Kingsley, Charles, Rev. (1819-1875).

Lamb, Charles (1775-1834).

LAMPSON-Locker, FrederICK (1821-1895).

Landon, Letitia Elizabeth (Mrs. MacleaN)-'L. E. L.' (18021838).

LaNdor, Walter Savage (1775-1864).

LINDSAY (BARNARD), ANNE, Lady (1750-1825).

LoDge, THOMAS (1558?-1625).

LogAN, JoHN, Rev. (1748-1788).

LONGFELLOW, HENRY WADSWORTH (1807-1882).

LOVER, SAMUEL (1797-1868).

LoWell, James RUSSELl (1819-1891).

LYLY (LILLY, LYLIE), JoHN (1554 ?-1606).

Maca Ulay, Thomas Babington, Lord (1800-1859).

Mahony, Francis Sylvester (' Father Prout') (1804-1866).

Mickle, William Julius (1735-1788).

Milliken, Richa Rd Alfred (1767-1816).

Milman, Henry Hart, D.D., Dean of St. Paul's (1791-1868).

Milnes, Richard Monckton, Lord Houghton (1809-1885).

MoNTgOMERY, JAMES (1771-1854).

Montrose, James Graham, Marquis of (1612-1650).

MOORE, Thomas (1779-1852).

MoRRIS, William (1834-1896).

Newman, John Henry, D.D., Cardinal (1801-1890).

Parnell, Thomas, D.D., Archdeacon (1679-1718).

Patmore, Coventry Kearsey Dighton (1823-1896).

Percy, Thomas, Bishop (1729, or 1728-1811). 
Philips, Ambrose (1671, or 1675 ?-1749).

Praed, Winthrop Mackworth (1802-1839).

Poe, Edgar Allan (1811-1849).

Rossetti, Christina Georgina (1830-1894).

Rossetti, DaNTE GABRIEL (1828-1882).

SCOTT, WALTER, Sir (1771-1832).

Shelley, Percy Bysshe (1792-1822).

Shenstone, William (1714-1763).

ShIRLEY, JAMES (1596-1666).

Smart, Christopher (1722-1771).

SOUTHEY, ROBERT, D.C.L. (1774-1843).

Stevenson, ROBERT Louis (1850-1894).

Tennyson, ALFred, Lord (1809-1892).

Trench, Richard Chenevix, D.D., Archbishop (1807-1886).

VERE, AUBREY DE, Sir (1788-1846).

VERE, AUBREY THOMAS DE (1814-1902).

Warton, Thomas (1728-1790).

WATTS, IsAac, D.D. (1674-1748).

WEBSTER, JOHN (1580 ?-1625 ?).

White, Joseph Blanco (1775-1841).

Wilson, John, Profeseor ('Christopher North') (1785-1854).

Wither (or Withers), Georae (1588-1667).

Wolfe, Charles, Rev. (1791-1823).

WORDSWORTH, WILLIAM (1770-1850).

WOTTON, HENRY, Sir (1568-1639). 


\section{INDEX OF FIRST WORDS}

PAGE

A beam of fun outbroke . . . . . . . . . 306

Abou Ben Adhem-may his tribe increase . . . $\quad 86$

A casement high and triple-arch'd there was . . . . 125

A castle, precipice-encurled . . . . . . . . 313

A cherub who had lost his way . . . . . . 221

A creature Beautiful to see . . . . . . . 14

A dead time's exploded dream . . . . . . 294

A dreamy sound . . . . . . . . . 277

A drowzy frowzy poem, call'd the 'Excursion' . . . 90

A greater name The list of Glory boasts not . . . . 40

Ah ! how the streamlet laughs and sings! . . . . 215

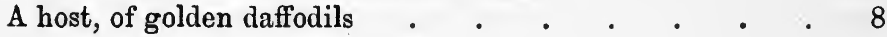

Ah what avails the sceptred race . . . . . . 70

Airly Beacon, Airly Beacon . . . . . . . 180

A language dead . $\quad . \quad$. $\quad . \quad$. $\quad . \quad 249$

Alas for the woful thing . . . . . . . . 258

All are needed by each one $\quad$. $\quad . \quad$. $\quad . \quad$. 192

All impulses of soul and sense. $\quad$. $\quad . \quad$. $\quad . \quad 32$

All Mothers worship little feet $\quad$. $\quad$. $\quad$. $\quad$. $\quad 249$

All the bliss that life endears . . . . . . . . 165

All the breeze of Fancy blows. . . . . . . 327

A man becomes aware of his life's flow . . . . . 288

A mighty band . . . . . . . . . 14

A music rained through the room . . . . . . 253

An aged man now enter'd . . . . . . . . 66

And crown him martyr; and his name will ring . . . 184

And Harald reigned and went his way . . . . . 275

And if I laugh at any mortal thing . . . . . 100 
And if one or two quick tears . $\quad . \quad$. $\quad . \quad 4 \quad . \quad 469$

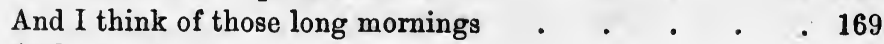
And lay, like his, my hands together . . . . . 304 And o'er the hills, and far away . . . . . . 318 And o'er the plain, where the dead age . . . . . 288 And such I knew, a forest seer . . . . . . 194 And there was given me back the sacred gift of tears . . 369 And they jeered him one and all: 'Poor Hóseyn is crazed past hope!' . . . . . . . . . 311 And thou, dread statue! yet existent in . . . . . $\quad$. 96 And when I am taen and hangit, mither, a brittling o' my

deer . . . . . . . . . . 180 And yet as young And warm with life . . . . . 84 And yet no earthquake came to swallow me . . . . . 184 An end of Ismail-hapless town ! . . . . . . 98 An English home-gray twilight pour'd . . . . 322 An Idyll with Boccaccio's spirit warm . . . . . 22 A quick and sudden cry . . . . . . . . 140 Are shaken the dews that waken . . . . . . 113 Art thou poor, yet hast thou golden slumbers? . . . 339 As 1 was walking all alane . . . . . . . 351 Ask if I love thee? Oh, smiles cannot tell . . . . 179 A solemn music of the wind . . . . . . . 23 A song,-nay, a shriek that rent the sky . . . . 254 A song where flute-breath silvers trumpet-clang ? . . . 356

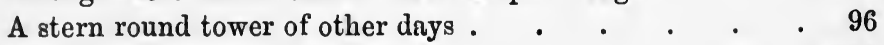
As the evening shades descended . . . . . . 214 At first to the ear . . . . . . . . 317 A thing of beauty is a joy for ever . . . . . . 118 At large among the dead . . . . . . . 145 At nightfall, at last . . . . . . . . . . 295 A voice by the cedar tree . . . . . . . 325 Awful coveys of terrible things . . . . . . 161 A widow bird sate mourning for her love . . . . 109 A woodland enchanted! . . . . . . . . 225 A young bird's flutter from a wood. . . . . . 119 
Beautiful as a wreck of Paradise . . . . . . 105

Beauty is truth, truth beauty-that is all . . . . 118

Behold her, single in the field . . . . . . 6

Behold he watches at the door! . . . . . . 188

Bend, save whole nations! would not that atone . . . 183

Birds here make song, each bird has his . . . 290

Blest be his generous heart for aye ! . . . . 64

Blood must be my body's balmer . . . . . . 336

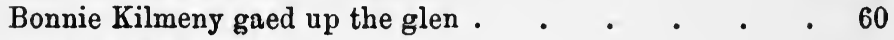

Break, break, break . . . . . . . . 322

Breast high amid the corn . . . . . . . 164

Bride of the heir of the kings of the sea . . . . 326

Brother, thou art gone before us, and thy saintly soul is

flown . . . . . . . . 140

But a day For wasting fire, and dying groan . . . $\quad 50$

But oh! that deep romantic chasm which slanted . . $\quad$ - 31

By that consenting scared and shock'd . . . . . 242

Can it be, and can it be ? . . . . . . . 278

Can you paint a thought? or number . . . . . 343

Cervantes smiled Spain's chivalry away . $\quad$. $\quad$. $\quad$ • $\quad$ • 99

Chants as of a lonely thrush's throat . . . . . 244

Charm, the glory which makes . . . . . . 291

Childless and crownless in her voiceless woe . . . . 95

Children, at midnight . . . . . . . . 296

Come, let the burial rite be read, the funeral song be sung . 199

Contemplative, corpulent, witty . . . . . . 281

Come to me in the silence of the night . . . . . 364

Creep into thy narrow bed . . . . . . . 290

Dark, deep, and cold the current flows . . . . . 366

Daughter, daughter, remember you . . . . . 254

Daughter of the gods, divinely tall $\quad$. $\quad$. $\quad$. $\quad 319$

Dear Harp of my Country ! in darkness I found thee . $\quad .80$

Death rides upon the sulphury Siroc . . . . . 94

Death, which takes me from his side . . . . . 244 


\section{INDEX OF FIRST WORDS}

PAGE

Does the road wind uphill all the way ? . . . . 364

Doomed to go in company with Pain . . . . . 14

Down in yon garden sweet and gay . . . . . 347

Earth has not anything to show more fair a $\quad$. $\quad$. $\quad$. 9

Ere I plunged amid the avenging flame . . . . . 157

Ere Sin could blight, or Sorrow fade . . . . . . 22

Eternal passion! . . . . . . . . . . . 291

Eternity in icy halls $\quad . \quad$. $\quad . \quad$. $\quad . \quad$. $\quad . \quad$. 97

Ethereal minstrel! pilgrim of the sky ! . . . . . 8

Even at its brightest play . . . . . . . 248

Every morning, far withdrawn . . . . . . 322

Every mountain now hath found a tongue . . . . 97

Faintly as tolls the evening chime . . . . . $\quad$. 77

Fair was she to behold, that maiden of seventeen summers . 210

Far and near, In wood and thicket . . . . . . 31

Father, mother, and careful child . . . . . . 165

Fear death ?-to feel the fog in my throat . . . . 304

Flake by flake . . . . . . . . . . 106

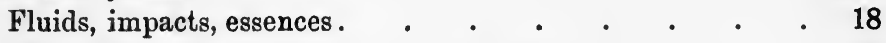

'For cruel 'tis,' said she . . . . . . . . . 126

For men must work, and women must weep . . . . . 183

For shade to shade will come too drowsily . . . . 120

For thou wert born of woman! thou didst come . . . 139

Fresh odour, sent . . . . . . . . . 105

Friends, dear friends, when it shall be . . . . . 174

From the blazing chariot of the sun . . . . . 12

From the forests and highlands . . . . . . 109

Gliding and springing . . . . . . . . 113

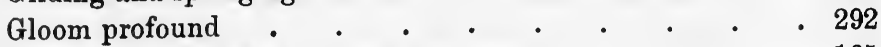

Gold, still gold! hard, yellow, and cold . . . . . 165

Go-lead the Hebrew forth, array'd . . . . . . 141

Gone into the West . . . . . . . . 164

Great, or good, or kind, or fair . . . . . . . . 344 
Great Socrates-And thou, Diviner still .

Had she come all the way for this?

Had'st thou but liv'd though stripp'd of power

Hark, now everything is still .

Hark! through the alley resounds .. . . . . . . . 291

Heard ye the arrow hurtle in the sky ? . . . . . 136

'Hear me, neighbours !' at last he cried- . . . . 365

Heeded, tho' sinking as if into death . . . . . . 67

He enter'd, but he enter'd full of wrath . . . . 126

He has cut his throat at last! He! Who? . . . . 90

Heigh ho, would she were mine ! . . . . . . . 342

He knew what pains must pierce a sister's heart . . . 130

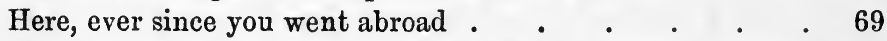

Here, when Art was still religion, with a simple reverent heart

He serveth the servant . . . . . . . . . 193

He that loves a rosy cheek . . . . . . . . . . 343

He who hath bent him o'er the dead . . . . . $\quad$. 93

His jante Up throu the milkye waye . . . . . $\quad$. 57

Home they brought her warrior dead . . . . . . 324

Home To the glory that was Greece . . . . . 205

How boldly doth it front us! how majestically ! . . . 138

How came it you resume the void and null . . . . 357

How light the touches are that kiss . . . . . 243

How light we go, how soft we skim! . . . . . 278

How sweet it were, hearing the downward stream . . 318

How sweet it were, if without feeble fright . . . . 86

How sweetly that bell warbled o'er the water! . . . 67

How sweet the air is! How fair the scene! . . . . 216

Hungry and wild, to claim their property . . . . 156

Hunt God's cattle upon God's ain hills . . . . . 180

Hush, my bonny babe!-hush, and be still! . . . . . 59

Hush ! my dear, lie still and slumber . . . . . . 353 
I am the nearest nightingale .

I arise from dreams of thee . . . . . . . 108

I ask'd my fair one happy day . . . . . . 20

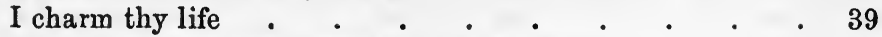

I could have laughed myself to scorn to find . . . . 14

I crawled to you . . . . . . . . . . 184

If but self-approved, to praise or blame . . . . . 42

I felt not, whose fate . . . . . . . . 165

If fate Love's dear ambition mar . $\quad . \quad$. $\quad . \quad$. $\quad 241$

If I had thought thou could'st have died $\quad . \quad$. $\quad . \quad . \quad 134$

'If I were dead, you'd sometimes say, Poor Child!' • . 246

If the veriest cur would lick my hand . . . . . 165

If thou would'st view fair Melrose aright $\quad . \quad$. $\quad . \quad 49$

I have been here before . . . . . . . . 260

I have dreamed a dreary dream . . . . . . . . 346

I have had playmates, I have had companions _ . . $\quad$. 359

$I$, in a mortal sorrow, still pursue . . . . . . . 246

1 know a little garden-close . . . . . . . 270

I loved him not; and yet now he is gone . . . . 72

I loved you, Evelyn, all the while! . . . . . 306

I love thee-I love thee! . . . . . . . . 164

I love thee not, I dare not love thee ! go $\quad . \quad$. $\quad .168$

I maun gae, tho' I ne'er return . . . . . . 347

I met a traveller from an antique land . . . . . . 114

I'm wearing awa', Jean . • . . . . . . 358

In he came with eyes of flame . . . . . . 36

Insect lover of the sun . . . . . . . . 193

In the long sunny afternoon . . . . . . . 195

In the touch of this bosom there worketh a spell . . $\quad 30$

Into the Silent Land! . . . . . . . . 209

Into the valley of Death . . . . . . . . 326

In vain, through every changeful year . $\quad . \quad$ : $\quad 12$

In Venice Tasso's echoes are no more . $\quad . \quad$. $\quad . \quad$. 95

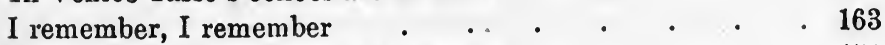

I saw thee once, and nought discern'd . . . . . 151

Is it no dream that I am he . . . . . . . 71 
Is the finger of God, a flash of the will that can

I strove with none; for none was worth my strife.

I thought once how Theocritus had sung

It is gone, the palace of music I reared!

173

It is-last stage of all

It is not while beauty and youth are thine own

It's lang sin' I lost baith my father and mother

307

It moan'd as near as near can be .. . . .

Its melancholy, long, withdrawing roar. .

Its strings Boldlier swept

It stood, and sun and moonshine rain'd their light

289

It was many and many a year ago . . . . . . . 201

It was not like your great and gracious ways! . . . 245

I've heard of hearts unkind, kind deeds . . . . . 13

I went sighing past the Church across the moorland dreary - 180

I went to sleep; and now I am refresh'd . . . . 156

I will not die alone. $\quad . \quad$. $\quad . \quad$. . . 321

I will paint her as I see her . . . . . . . 172

Last night the delicate crests of saffron bloom a . . 247

Lay dead, And the great Rustum drew his horseman's cloak 294

Legend strange and vague . . . . . . . 215

Less from disgust of life than dread of death. $\quad . \quad$. $\quad$. 99

Let Fate do her worst, there are relics of joy . . . $\quad 78$

Let him never come back to us! . . . . . . 304

Let us begin and carry up this corpse . . . . . 308

Lifts me to the golden doors . . . . . . . . . 320

Like a dream through sleep she glided . . . . . . 233

Like a forgotten lute, play'd on alone . . . . . . 137

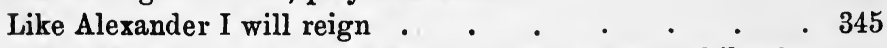

Like a sick child that knoweth not his mother while she

blesses . . . . . . . . 173

Like the leaves of the forest when Summer is green _ . 91

Lisped in numbers, and the numbers came . . . . . 384

Listen to me, as when you heard our father . . . . 372

Little feet across the lawn . . . . . . 57 
Little gossip, blithe and bale . . . . . . . 355

Lo, an English mansion founded . . . . . $\quad$. 230

Lo! a third man rose o'er the wave . . . . . 255

Long I followed happy guides . . . . . . . 190

Long procession Still passing to and fro . . . . . 211

Ioved, when my love from all but thee had flown . $\quad . \quad 70$

Love in my bosom like a bee . . . . . . . 342

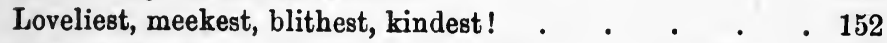

Love strikes but one hour-Love! Those never loved . 174

Love thy mother, little one ! . . . . . . . 162

Mary mine that art Mary's rose . . . . . . 252

Men granted that his speech was wise . . . . . 224

Men have been brave, but women have been braver! . $\quad 67$

Men said he saw strange visions . . . . . $\quad$. 370

Methought I saw the grave where Laura lay . . . . 336

Mighty poets in their misery dead . . . . . . 386

Mother, I cannot mind my wheel . . . . . . $\quad$. 71

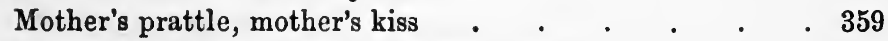

Much have I travell'd in the realms of gold . . . . 124

Music by the night-wind sent. . . . . . . . 114

Music, when soft voices die . . . . . . 110

My days among the Dead are past . $\quad$. $\quad$. $\quad . \quad 40$

My heart aches, and a drowsy numbness pains . . . 123

My lady seems of ivory . . . . . . . . . 272

My little Son, who look'd from thoughtful eyes . • . 247

'My Lord has need of these flowerets gay' . . . . . 212

My parents bow, and lead them forth . . . . . $\quad$. 179

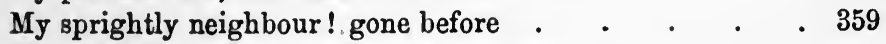

Myself when young did eagerly frequent . . . . 236

Mysterious Night! when our first parent knew . . . 368

My youth was happy; but this hour belike is best . $\quad 270$

Never stoops the soaring vulture . . . . . . 210

Nightingales warbled without . . . . . . . 324

Night in the lonesome October . . . . . . 200 
No Cain Injures-uninjured .

No more of dreaming

No sword Of wrath her right arm whirl'd

Nor could his lips a deep-drawn sigh restrain

118

Not a breath crept through the rosy air

Not a drum was heard, not a funeral note

Not a whisper stirs the gloom

Not from the grand old masters

Now he is dead! Far hence he lies

329

Now sleeps the land of houses

130

100

132

329

212

293

271

O Albion ! 0 my mother Isle !

' $O$ God, forgive me,' he exclaim'd

0 God! let me breathe, and look up at the sky! .

22

0 hark, $O$ hear! how thin and clear

85

0 Helen fair, beyond compare !

o Mary, go and call the cattle home

0 my sweet baby! when I reach my door

0 Nightingale! thou surely art

0 Sheik, I cannot leave thee so

0 tell me, friends, while yet ye hear

O Thou, in that mysterious shrine .

0 what a loud and fearful shriek was there

Obscurely spotted to the door, and thence

324

348

182

22

283

O'er Roslin all that dreary night . . . . . . . . 49

Of all the girls that are so smart . . . . . . . . 356

Of a life lived somewhere, I know not . . . . . . 227

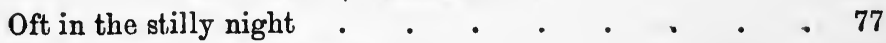

Of two that died last night . $\quad . \quad$. $\quad . \quad$. $\quad . \quad$. 84

$\mathrm{Oh}$ ! breathe not his name, let it sleep in the shade . . 78

$\mathrm{Oh}$ ! but to breathe the breath . . . . . 160

Oh could I feel as I have felt $\quad . \quad$. $\quad . \quad$. $\quad$. 92

$\mathrm{Oh}$, God! to think Man ever . . . . . . . 165

$\mathrm{Oh}$, had I lived in that great day . . . . . . . 292

Oh, the little more, and how much it is ! . . . . 307

$\mathrm{Oh}$, what a heart-subduing melody! . . . . . 156 
Oh, world ! oh, life! oh, time ! . . . . . . 111 Once in a golden hour . . . . . . . . $\quad$. 330

Once more in more than bridal beauty stands . . . 234

Once upon a midnight dreary, while I pondered, weak and weary . . . . . . . . . . 199

One have I marked, the happiest guest . $\quad$ - . 8

On either hand With Milton and with Keats . . . 357

On Elysian lawns . . . . . . . . . 122

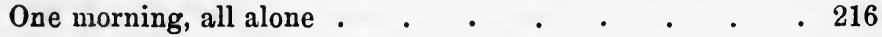

One word is too often profaned . $\quad . \quad$. $\quad . \quad$. 112

On this sweet bank your head thrice sweet and dear . . 259

Open here I flung the shutter, when, with many a flirt and

flutter . . . . . . . . 199

Our signal for fight that from monarchs we drew . . 48

Pale Rose Mary sank to the floor . . . . . 252

Pride To think how little I dreamed it led . . . . 307

Queen with swarthy cheeks and bold black eyes . . . 319

Radiant, sharpest-sighted god . . . . . . . 193

Rarely, rarely comest thou' . . . . . . . 110

Remember thee? Yes, while there 's life in this heart. $\quad . \quad 79$

Rendered answer high . . . . . . . . 319

Rock's the song-soil rather, surface hard and bare . . 314

Round her she made an atmosphere of life . . . $\quad 100$

Round the Cape of a sudden came the sea . . . . 306

Rushing, ten thousand horsemen came . . . . . 46

Said one among them-' Surely not in vain . . . . 237

Sanctuary and home Of art and piety . . . . . 95

Sapping a solemn creed with solemn sneer . . . . . 97

Say not, the struggle nought availeth . . . . $\quad$. 282

Say to the Court, it glows . . . . . . . . . 336

Season of mists and mellow fruitfulness $\quad . \quad$. . . 121

Sees Levet to the grave descend . . . . . . . 355

Shady spots and nooks, where we . . . . . . . 144 
She, answering, own'd that she lov'd too

She dwelt among the untrodden ways . . . . . . 5

She is not fair to outward view . . . . . . . 368

She listen'd to the tale divine . . . . . . 21

She stood with amazement . . . . . . . 165

She 's the most distressful country . . . . . . . $\quad$. 369

She walks in beauty, like the night . . . . . 92

She was a Phantom of delight . . . . . . . 6

Shone from the solitary peak at Edgbaston . . . . 249

Showed my youth How Verse may build . . . . 14

Shuffling Southey, that incarnate lie . . . . . 90

Since I noo mwore do see your feäce . . . . . 361

Sir Patrick Spens, the best sailor . . . . . . . 346

Slow sinks more lovely ere his race be run . $\quad$ - $\quad$. $\quad 92$

Small hope, my girl, for a helm to hide. . . . . 253

Soft touch invisible. . . . . . . . . 145

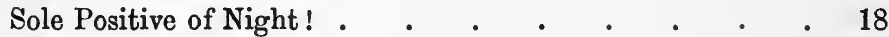

Sole sovran of the Vale! . . . . . . . . 24

Sometimes on lonely mountain-meres . . . . . 320

Sometimes wondering soul . $\quad$. $\quad$. . . . 292

Soon or late sardonic Fate . . . . . . . . . 232

'Sorrow', said Mahmoud, 'is a reverend thing' . . $\quad 85$

So sleep, for ever sleep. 0 marble pair! . . . . 293

Souls of poets dead and gone. . . . . . . . . 122

Soul was like a star, and dwelt apart . . . . . . 14

Sound the loud timbrel o'er Egypt's dark sea! . . $\quad 76$

Speak not thy speech my boughs among _ . $\quad$. $\quad$. $\quad 189$

Splendid a star? . . . . . . . . . 303

Spreading May's leafless blooms in a damp nook . . 193

Star is not equal to star, nor blossom the same as blossom . 280

Stay, stay . . . . . . . . . . 380

Still in her web delights. . . . . . . . 320

Strange is it not? that of the myriads who . . . . 236

Sweet my child, I live for thee . . . . . . . 325

Sweet nurslings of the vernal skies . . . . . . 145

Sweet stranger, whom I called my wife . . . . . 243 
Take me away, and in the lowest deep .

'Tears, idle tears,' I know not what they mean . . . . 325

Tender beings angelical.

- 156

Thank Heaven, the crisis

- 201

That felt Thee kneeling-touch'd Thy prostrate brow . . 145

That first in beauty should be first in might . . . . 118

That Lord Arundel . $\quad . \quad$. $\quad . \quad$. $\quad . \quad$. $\quad .291$

That very night, while gentle sleep $\quad . \quad$. $\quad . \quad$ • $\quad$. 160

The bee hums on; around the blossomed vine . $\quad . \quad 222$

The bees that soar for bloom . . . . . . . 12

The billows whiten and the deep seas heave . . . . 278

The brightness of the world, 0 thou once free . . . $\quad 22$

The fairest flower The braes of Ettrick ever saw . . $\quad$. 57

The floating clouds their state shall lend . . . . 5

The Flowers of the Forest a' wede away . . . . . 358

The fond aspiring song . . . . . . . . 63

The forms of the departed . . . . . . . . 211

The fruit-like perfume of the golden furze . $\quad$. $\quad 20$

The glories of our blood and state . . . . . . . . 341

The God's will sallies free . . . . . . . 191

The green, green grass, the glittering grove . • . . 152

The hand that rounded Peter's dome . . . . . 192

The harp that once through Tara's halls $\quad . \quad$. $\quad$. 77

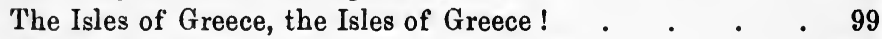

The keen sanctity . $\quad . \quad$. $\quad . \quad$. $\quad$. $\quad$. 157

The kingly bard . $\quad . \quad$. $\quad . \quad$. $\quad . \quad$. 191

The King's daughter o' Noroway . . . . . . . 346

The landscape, all made sharp and clear . . . . . 242

The lark now leaves his wat'ry nest . . . . . 344

The leaves are falling; so am I . . . . . $\quad 71$

The Lord from out His cloud . $\quad$. $\quad . \quad$. $\quad . \quad 138$

The lost days of my life until to-day $\quad$. $\quad . \quad$. 260

The mildest manner'd man . . . . . . . . 100

The month of March wore on apace . . . . . 256

The multitudinous Billows . • . . . . . 115

The murmur of the mourning ghost . . . . 362 
The night is gone

The noon of autumn's glow . $\quad$. $\quad . \quad$. $\quad . \quad 115$

Then rose from sea to sky the wild farewell . . . . 98

Then think I of deep shadows on the grass . . . . 225

The odorous purple of a new-born rose $\quad$. $\quad . \quad 497$

The pageant of his bleeding heart . . . . . 101

The people-ah, the people- . . . . . . 200

The Rainbow comes and goes . . . . . . 10

The Raven, never flitting, still is sitting, still is sitting $\quad .199$

There are sweet flowers that only blow by night . . . 70

There 's a great text in Galatians . . . . . . 304

There is a garden in her face . . . . . . . 344

There is a stream, Springing far off . . . . . 279

There is no sterner moralist than Pleasure ! . . . . 99

There is no music in the life . . . . . . . 166

There is one Mind, one omnipresent Mind . . . 18

There sat a Lady all on the ground . . . . . 153

There thou sittest; now and then thou moanest . . . 222

There was a lady lived in a hall . . . . . . . 269

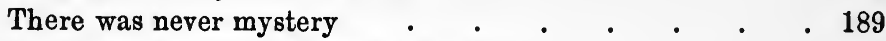

The Roman, when his burning heart . . . . . 91

The secrets of the wind it sings . $\quad$. $\quad$. $\quad$. $\quad$. 227

The self-torturing sophist, wild Rousseau . . . . 97

The sharp storm cuts her forehead bare . . . . 223

The skies have sunk, and hid the upper snow _ . $\quad 279$

The soft green willow springing . . . . . . 145

The sounding cataract . . . . . . . . 14

The spacious firmament on high . . . . . . 353

The star of the unconquered will . . . . . . 212

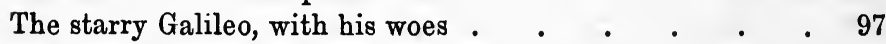

The vision of scarce a moment . . . . . . . 226

The voice of friends around the bed . . . , . 157

The warm, green-muffled Cumner hills . . . . . 296

The water comes down at Lodore . • . . . . 42

The Wedding March of Mendelssohn . . . . . 241

The winds are high on Helle's wave $\quad$ - $\quad$. $\quad$. $\quad$ - 93 
The words are utter'd, and they flee

The World 's a bubble, and the Life of Man .

338

The world is too much with us; late and soon

The world, the clustering spheres, He made .

356

They are at rest

They close, in clouds of smoke and dust

They pass me by like shadows, crowds on crowds .

They pity me, and not my grief !

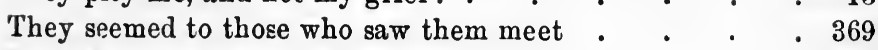

They sin who tell us Love can die . . . . . . 41

Think in this battered Caravanserai . . . . . 235

This flower she stopped at, finger on lip . . . . 305

This is her portrait as she was . . . . . . 261

This vault which glows immense with light . . . . 196

Thou art the unanswered question . $\quad$. $\quad$. $\quad . \quad 192$

Thou dreariest droll of puffy short-breath'd writers ! . $\quad 69$

Tho' I should die, I know . . . . . . . . 322

Those magic numbers . . . . . . . . 214

Thou hast chosen the Human, and left the Divine ! . . 174

Thou little think'st and less dost know . . . . . 338

Thou, Primal Love, who grantest wings . . . . . 241

Through an alley Titanic . • . . • , . 200

Through the open door The night-wind wailed $\quad$ • $\quad .256$

Through the open window, loud and clear . . . . 214

Thus fell the boy on the beast; thus rolled up the beast in

his horror . . . . . . . . 178

Thus the bard of love departed . . . . . . . 213

Lhus with old Priam, with his royal line . . . . 232

Thy roof will fa', thy rafters start . . . . . . 57

'Tis calm indeed! so calm, that it disturbs . . . . 21

'Tis Death-0 loving friends, your prayers! 'tis he! . . 155

'Tis I wad clead thee in silk and gowd . . . . . 348

'Tis misty all, both sight and sound . . . . . . 146

'To be born a king!' . . . . . . . . 257

To his land, a lump of mould the more . . . . . 193

To mix with Kings in the low lust of sway . . . . 23 
PAGE

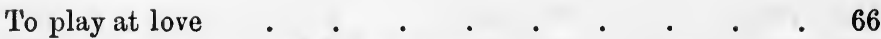

To tell, Of the wonderful days a-coming. $\quad . \quad$. $\quad . \quad 268$

Trusting to his noblest foes . . . . . . . 174

Tully was not so eloquent as thou . . . . . . $\quad$ • 96

"Twas not those souls that fled in pain . . . . . 27

'Twas when the spousal time of May . . . . . 242

Tweed said to Till ..$\quad$. $\quad . \quad$. . . . . 361

Twenty years hence my eyes may grow $\quad . \quad$. $\quad . \quad 669$

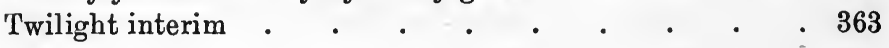

Under the may she stoop'd to the crown $\quad . \quad$. $\quad . \quad 269$

Ungrateful Florence : Dante sleeps afar . . • . 95

Unless you pardon, what shall I do, Lord? . . . . . 266

Upon the gold clouds metropolitan . . . . . 127

Up and spake the Swan-neck high . . . . . . . 181

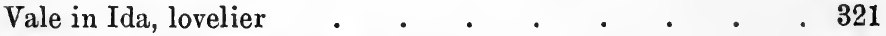

Very true, the linnets sing . . . . . . . . 70

Victorious men of earth, no more . $\quad . \quad$. $\quad . \quad 340$

Wandering between two worlds, one dead . . . . 295

Watching the pulse of the oars die down, as her own died with them . . . . . . . . . 178

We have all of us one human heart . . . . . 14

Welcome, bud beside the rose . . . . . . 84

Well it is for us our God should feel . . . . . . 148

Were I a trembling leaf . . . . . . . . $\quad$. 360

We watch'd her breathing thro' the night . . . . 162

What am I . . . . . . . . . . . 327

What a scream of agony $\quad . \quad$. $\quad . \quad . \quad .25$

What bird so sings, yet so does wail ? . . . . . . 342

What Elysium have we known . . . . . . 122

Whatever in her sight I'd seem . . . . . . 241

Whate'er our household gods protect of dear . . $\quad 100$

What hath he lost that such great grace hath won? . . 336

What ills the scholar's life assail . . . . . . 355 
What 's the soft South-Wester?

What leaf-fringed legend haunts about thy shape.

What man has made of man .

What means yon blaze on high?

When at home alone I sit

When half-gods go .

When I am dead, my dearest .

371

193

When I lov'd you, I can't but allow

364

When Nature shrouds herself, entranced

When Nero perish'd by the justest doom

When summer's hourly-mellowing change

When the breeze of a joyful dawn blew free

327

When the lamp is shattered.

317

When the little wee bit heart

112

When the new-made Mother smiled

When thy beauty appears

Where Baly held of old his awful reign

244

353

Where'er we tread 'tis haunted, holy ground!

Where is the grave of Sir Arthur 0'Kellyn?

Where is thy favoured haunt, eternal Voice?

Where rests the sap within the leaf

Where waters gushed and fruit-trees grew . . . . 311

Whether at Naishảpúr or Babylon . . . . . . 235

Whither, 'midst falling dew . . . • . . . 366

Whoe'er has travel'd life's dull round . . . . . 354

Who ever saw the earliest rose . . . . . . . 147

Who fears to speak of 'Ninety-Eight? . . . . . . 369

Who is he that cometh, like an honour'd guest ? . . . 326

Who on earth have made us heirs . . . . . . 15

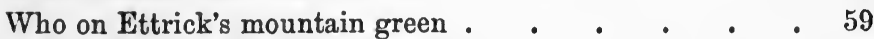

Who's striving Parnassus to climb . . . . . . 221

Who trod upon the senseless turf would think . . . 40

Why does your brand sae drop wi' blude? . . . . 349

Why, 'twas a very wicked thing ! . . • . . . 36

Wild as the scream of the curlew . . . . . . 48

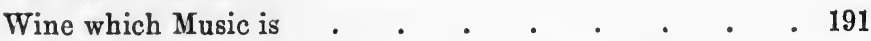


With dun-red bark The fir-trees . . . . . . $\quad 20$

With more than mortal powers endow'd . . . . 51

With one black shadow at its feet . . . . . . . 321

With the breeze murmuring in the musical woods. . 105

With the magic hand of chance. . . . . . . . 127

With thee, $\mathrm{O}$ gentlest of my friends ! . . . . . 211

Wolves' eyes, through the windows peer . . . . 223

Words which may wake the dead! . . . . . 184

Wretches! ye loved her for her wealth and hated her for her pride

Ye taught my lips a single speech . . . . . . 188

Yes, in Thalia's son . . . . . . . . . 68

You may esteem him . . . . . . . . . . 344

You meaner beauties of the night . . . . . . 337

You say, 'Since so it is,-good-bye . . . . . . 281

'You were taken aback, poor boy,' they urge, 'no time to regain your wits' . . . . . . . . 310 


\section{ERRATA}

Vol. I, p. 78, for The Second Anniversary, vv. 425-8 read The First Anniversary, vv. 427-8

Vol. II, p. 1, for Romancists read Romanticists 
OXFORD: HORACE HART

PRINTER TO THE UNIVERSITY 




\section{University of Toronto Library}

DO NOT

REMOVE

THE

CARD

FROM

THIS

POCKET

Acme Library Card Pocket LOWE-MARTIN CO. LIMITED 
